UNIVERSIDADE DE SÃO PAULO

HENRIQUE DE SOUZA DORNELLES

CARACTERIZAÇÃO MICROBIANA DA REMOÇÃO E DEGRADAÇÃO DE 4-NONILFENOL EM REATOR ANAERÓBIO DE LEITO FLUIDIFICADO EM ESCALA AUMENTADA

VERSÃO CORRIGIDA

São Carlos

2019 

HENRIQUE DE SOUZA DORNELLES

\title{
CARACTERIZAÇÃO MICROBIANA DA REMOÇÃO E DEGRADAÇÃO DE 4-NONILFENOL EM REATOR ANAERÓBIO DE LEITO FLUIDIFICADO EM ESCALA AUMENTADA
}

\begin{abstract}
Dissertação apresentada à Escola de Engenharia de São Carlos da Universidade de São Paulo, como parte dos requisitos necessários para obtenção do título de Mestre em Ciências: Engenharia Hidráulica e Saneamento.
\end{abstract}

Orientadora: Maria Bernadete A. Varesche

VERSÃO CORRIGIDA

São Carlos

2019 
AUTORIZO A REPRODUÇÃO TOTAL OU PARCIAL DESTE TRABALHO, POR QUALQUER MEIO CONVENCIONAL OU ELETRÔNICO, PARA FINS DE ESTUDO E PESQUISA, DESDE QUE CITADA A FONTE.

Ficha catalográfica elaborada pela Biblioteca Prof. Dr. Sérgio Rodrigues Fontes da EESC/USP com os dados inseridos pelo(a) autor(a).

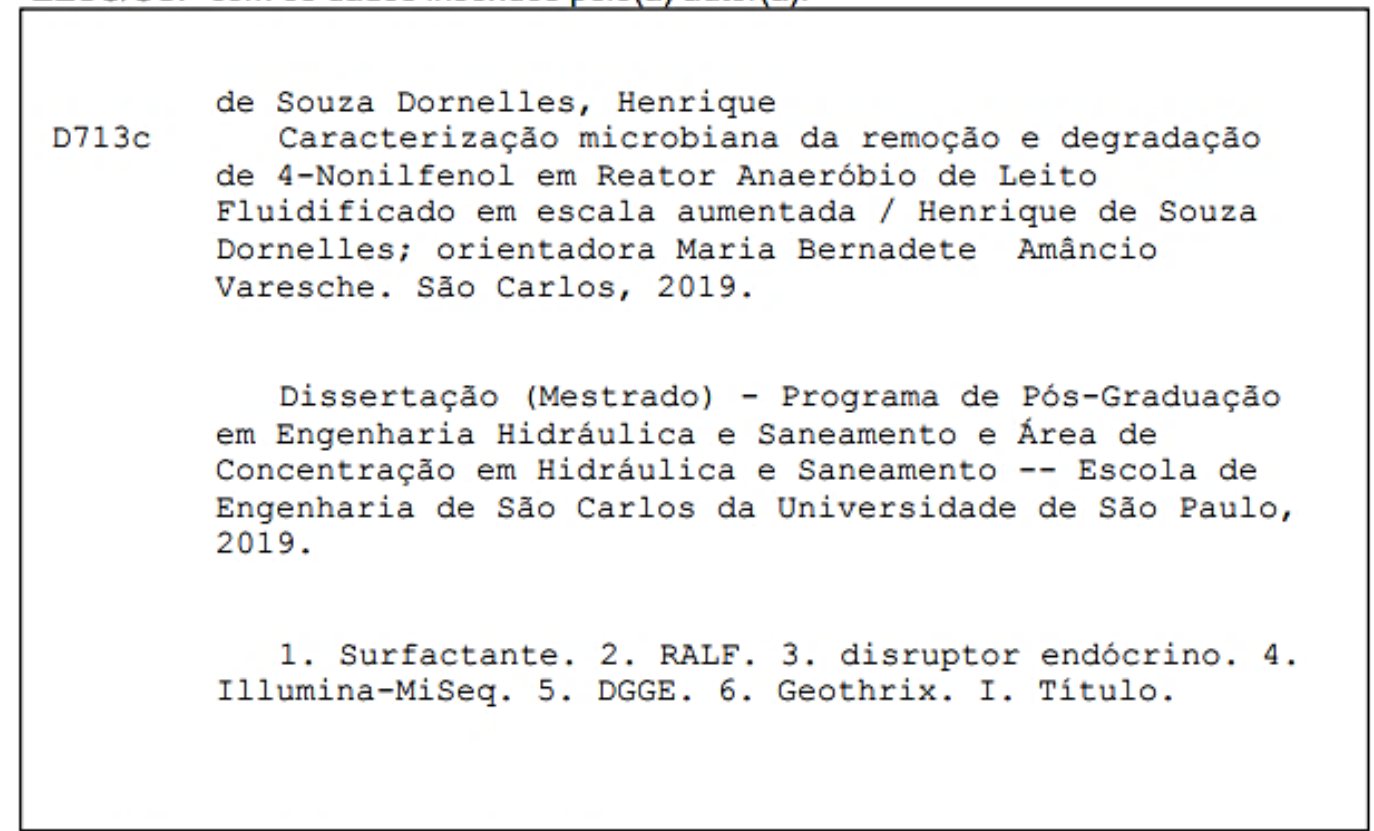

Eduardo Graziosi Silva - CRB - 8/8907 


\section{FOLHA DE JULGAMENTO}

Candidato: Engenheiro HENRIQUE DE SOUZA DORNELLES.

Título da dissertação: "Caracterização microbiana da remoção e degradação de 4-nonilfenol em reator anaeróbio de leito fluidificado em escala aumentada".

Data da defesa: 21/02/2019.

Comissão Julgadora:

Resultado:

Profa. Associada Maria Bernadete Amacio Varesche Silva (Orientadora)

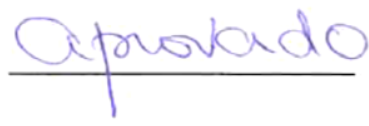

(Escola de Engenharia de São Carlos/EESC)

Prof. Dr. Jorge Akutsu

APnOVADO

(Universidade Federal de São Carlos/UFSCar)

Prof. Dr. Paulo Clairmont Feitosa de Lima Gomes

(Universidade Estadual Paulista "Júlio de Mesquita Filho"/UNESP-Araraquara)

Coordenador do Programa de Pós-Graduação em Engenharia Hidráulica e Saneamento:

Prof. Dr. Eduardo Mario Mendiondo

Presidente da Comissão de Pós-Graduação:

Prof. Associado Luis Fernando Costa Alberto 



\section{Dedicatória}

Aos meus pais Jair e Saionara, meus avós Miguel e Rosa e meus irmãos Eduardo, Arthur e Manuela, meus grandes apoiadores por trás de cada adversidade.

Dedico também ao generoso povo brasileiro,

pela oportunidade de estudar em uma universidade pública,

o meu grande sonho. 



\section{Agradecimentos}

À Fundação de Amparo à Pesquisa do Estado de São Paulo (FAPESP), pelo apoio concedido por meio da bolsa de mestrado (Processo n ${ }^{\circ}$ 2017/22850-7).

Ao Conselho Nacional de desenvolvimento Científico e Tecnológico (CNPq) e a Coordenação de Aperfeiçoamento de pessoal de Nível Superior (CAPES) pelo auxílio recebido.

Agradeço a minha excepcional orientadora Dra. Maria Bernadete A. Varesche pelo profissionalismo e comprometimento com o sucesso deste trabalho, por acreditar no meu potencial e sempre me instigar a evoluir.

Ao professor Dr. Edson Luiz Silva (Tininho), pelas valiosas sugestões e colaborações.

Aos meus pais Jair e Saionara, meus avós Miguel e Rosa, meus irmãos Eduardo, Arthur e Manuela pelo apoio incondicional em cada etapa da minha vida, por me incentivarem e acreditarem em minhas decisões.

Agradeço as melhores amigas Gabriela, Priscila e Tairine por estarem ao meu lado durante tantos anos e me proporcionarem momentos inesquecíveis, por me apoiar em cada dificuldade, por enxergarem beleza nas minhas diferenças e me fazerem acreditar nisso.

Agradeço aos amigos do LPB Franciele, Marina, Schayana (Schay), Jean, Carol Garcia, Adriana (Drica), Lucas, Mirabelle (Mira), Raquel, Fabrício, Alana, Raíssa, Alejandra, Tiago (Cebola), pela companhia, amizade e apoio durantes estes dois anos e os próximos que virão.

Agradeço as laboratoristas Maria A. Adorno (Janja), Isabel K. Sakamoto (Bel), Eloísa Pozzi (Elô) e Carolina Sabatini (Carol) pela disposição para qualquer auxílio que fosse necessário e pela companhia diária.

Agradeço aos professores Marcelo Zaiat e Eugênio Foresti pela companhia diária e inspiração.

Agradeço a todas a energias positivas do universo que conspiraram ao meu favor! 

"Se eu vi mais longe, foi porque estive sobre ombros de gigantes."

Isaac $\mathcal{N e w t o n}$ 



\section{RESUMO}

Dornelles, H.S. Caracterização microbiana da remoção e degradação de 4-Nonilfenol em Reator Anaeróbio de Leito Fluidificado em escala aumentada. 2019. 173 f. Dissertação (Mestrado) - Escola de Engenharia de São Carlos, Universidade de São Paulo, São Carlos, 2019.

O 4-Nonilfenol (4-NF) é o principal produto formado a partir da degradação do Nonilfenol etoxilado, surfactante não iônico amplamente utilizado em formulações de uso doméstico e industrial. Objetivou-se neste estudo desenvolver método de quantificação de 4-NF em HPLC; avaliar a remoção de 4-NF em reatores em batelada com co-substratos (etanol, metanol e fumarato) e avaliar a remoção e degradação de 4-NF em Reator Anaeróbio de Leito Fluidificado (RALF) em escala aumentada (20L), bem como caracterizar a comunidade microbiana estabelecida no material suporte por meio das técnicas de PCR/DGGE do gene RNAr 16S e sequenciamento massivo via plataforma Illumina-Miseq ${ }^{\circledR}$. O RALF foi preenchido com areia

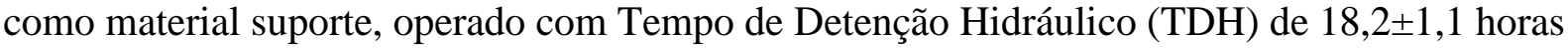
e alimentado com meio de cultura acrescido de 4-NF PESTANAL ${ }^{\circledR}$ (Sigma-Aldrich ${ }^{\circledR}$ ). Análises de monitoramento da concentração de 4-NF e matéria orgânica, bem como, dos parâmetros físico-químicos foram realizadas para avaliar a estabilidade do reator quanto a remoção e degradação do composto de interesse. A operação do reator foi dividida em distintas etapas, contando com inoculação do RALF em circuito fechado, adaptação ao meio de cultura e subsequentes fases com adição de 4-NF. Para reatores em batelada a adição de 4-NF (de $288,97 \pm 96,49$ a $469,98 \pm 182,42 \mu \mathrm{g} \mathrm{L}^{-1}$ ) favoreceu a produção média de metano acumulada (de 2.292,3 para 2.744,7 $\mu \mathrm{mol}$, respectivamente) para todos os co-susbtratos testados, todavia, retardou o tempo médio de início da produção (de 15,9 h para 107,9 h), bem como reduziu a velocidade de produção (de 24,4 para $10,9 \mu \mathrm{mol} \mathrm{d} \mathrm{d}^{-1}$ ). Para ensaio com adição de 4-NF e Fumarato foram verificados os maiores valores de produção acumulada de metano $(3.163,68 \pm 169,17 \mu \mathrm{mol})$ e de remoção de DQO $(75,52 \pm 0,34 \%$ para DQO inicial de $1.242,00 \pm 27,48 \mathrm{mg} \mathrm{L}^{-1}$ ), em relação aos demais ensaios com adição de 4-NF. Para a remoção de 4-NF em reatores em batelada os valores não diferiram significativamente. Para o RALF, foram verificadas eficiências médias de remoção de DQO de 90,34 $\pm 6,1 \%$ (Fase I), 94,0 $\pm 1,2 \%$ (Fase II), 97,0 $\pm 1,3 \%$ (Fase III) e 95 $\pm 1,5 \%$ (Fase IV) e 4-NF de 73,2 $\pm 11,1 \%$ (Fase II), $67,3 \pm 7,3 \%$ (Fase III) e 77,88 $\pm 8,9 \%$ (Fase IV). As diferentes concentrações de 4-NF aplicadas ao RALF não afetaram a eficiência de remoção de DQO e promoveram a seleção dos microrganismos que compuseram a biomassa do leito. Os gêneros mais abundantes identificados no reator sem adição de 4-NF foram Prolixibacter, Geothrix, Klebsiella, Lactobacillus e Geobacter. Os gêneros com maior abundância relativa identificados após adição de 4-NF foram os seguintes: Geothrix, Holophaga, Elusimicrobium, Paludibacter, Lactobacillus, Aeromonas, Pelobacter, Aquaspirillum, Pseudomonas, Delftia, Acinetobacter, Arcobacter, Ignavibacterium, Treponema, Lysinibacillus e Enterococcus.

Palavras-chave: Surfactante, RALF, desregulador endócrino, Illumina-MiSeq, DGGE, Geothrix. 



\begin{abstract}
Dornelles, H.S. Microbial characterization of 4-Nonylphenol removal and degradation in anaerobic Fluidized Bed Reactor in upscale. 2019. 173 p. Dissertation (Ms.c.) - School of Engineering of São Carlos, University of São Paulo, São Carlos. In 2019.

4-Nonylphenol (4-NP) is the main product formed in the Nonylphenol ethoxylate degradation, nonionic surfactant used in formulations of domestic and industrial use. The objective of this study was to develop a method to determine 4-NP in HPLC; to evaluate the 4-NP removal in batch reactors with co-substrates (ethanol, methanol and fumarate) and removal and degradation of 4-NP in anaerobic Fluidized Bed Reactor (AFBR) on an enlarged scale (20L), as well as characterize the microbial community established in the support material by PCR / DGGE techniques of the 16S RNAr gene and massive sequencing by the Illumina-Miseq ${ }^{\circledR}$ platform. The AFBR was filled with sand as carrier material, operated with Hydraulic Retention Time (HRT) of 18.2 \pm 1.1 hours and fed with synthetic sewage plus 4-NP PESTANAL ${ }^{\circledR}$ (SigmaAldrich $^{\circledR}$ ). Monitoring of the 4-NP concentration and organic matter, as well as physicalchemical parameters were performed to evaluate the stability of the reactor for the removal and degradation of the compound of interest. Reactor operation was divided into different stages, with inoculation of the RALF in closed circuit, adaptation to the culture medium and subsequent phases with 4-NF addition. The addition of 4-NP (from $288.97 \pm 96.49$ to $469.98 \pm 182.42 \mu \mathrm{g} \mathrm{L}$ ${ }^{1}$ ) in batch reactors favored the average accumulated methane production (from 2,292.3 to $2,744.7 \mu \mathrm{mol}$, respectively) for all tested co-susbtrates, however, delayed the mean time to start production (from $15.9 \mathrm{~h}$ to $107.9 \mathrm{~h}$ ), as well as reduced production rate (from 24.4 to $10.9 \mu \mathrm{mol}$ $\left.\mathrm{d}^{-1}\right)$. The highest accumulated values of methane production $(3,163.68 \pm 169.17 \mu \mathrm{mol})$ and COD removal $\left(75.52 \pm 0.34 \%\right.$ for the initial COD of $\left.1,242 \pm 27.48 \mathrm{mg} \mathrm{L}^{-1}\right)$ were verified for the addition of 4-NP and Fumarate, compared to the other tests with addition of 4-NP. For the 4NP removal in batch reactors the values did not differ significantly. Mean values of COD removal for the AFBR were 90.34 $\pm 6.1 \%$ (Phase I), 94.0 $\pm 1.2 \%$ (Phase II), 94.0 $\pm 1.2 \%$ (Phase III) and $97.0 \pm 1.3 \%$ (Phase IV) and 4-NF of 73.2 $\pm 11.1 \%$ (Phase II), 67.3 $\pm 7.3 \%$ (Phase III) and $77.88 \pm 8.9 \%$ (Phase IV). Different concentrations of 4-NP applied to the AFBR did not affect the COD removal efficiency and promoted the selection of the microorganisms that composed the bed biomass. The most abundant genera identified in the reactor without addition of 4-NP were Prolixibacter, Geothrix, Klebsiella, Lactobacillus and Geobacter. The genotypes with the highest relative abundance identified after addition of 4-NP were as follows: Geothrix, Holophaga, Elusimicrobium, Paludibacter, Lactobacillus, Aeromonas, Pelobacter, Aquaspirillum, Pseudomonas, Delftia, Acinetobacter, Arcobacter, Ignavibacterium, Treponema, Lysinibacillus and Enterococcus.
\end{abstract}

Keywords: Surfactant, AFBR, endocrine disruptor, Illumina-MiSeq, DGGE, Geothrix. 



\section{LISTA DE FIGURAS}

Figura 3.1 - Estrutura química do 4-Nonilfenol.

Figura 3.2 - (A): Concorrência para o receptor de ligação de estrogênio entre 4-NF e 17ßestradiol na célula eucarionte (SOARES et al., 2008) e (B): comparação de estruturas químicas de $17 \beta$-estradiol e 4-NF. 38

Figura 4.1 - Fluxograma geral das etapas de execução do projeto. 47

Figura 4.2 - Fluxograma experimental dos ensaios de potencial metanogênico. 51

Figura 4.3 - Reator Anaeróbio de Leito Fluidificado em escala aumentada (RALF). 52

Figura 4.4 - Fluxograma experimental das etapas de operação do RALF. 54

Figura 4.5 - Sequência de testes para quantificação de 4-Nonilfenol. 57

Figura 5.1 - Cromatogramas de 4-Nonilfenol em coluna cromatográfica C-8 (Agilent ${ }^{\circledR}$ ) e C-18 $\left(\right.$ Shimadzu $\left.^{\circledR}\right)$, com temperatura de $40^{\circ} \mathrm{C}$, fluxos de eluição de $0,8 \mathrm{~mL} \mathrm{~min}^{-1}$ e acetonitrila/água na proporção 90:10 (v/v) como fase móvel.

Figura 5.2 - Cromatogramas de 4-Nonilfenol em coluna cromatográfica C-8 (Agilent ${ }^{\circledR}$ ) com temperatura $40^{\circ} \mathrm{C}$, fluxos de eluição de $0,5 \mathrm{~mL} \mathrm{~min}^{-1}, 0,8 \mathrm{~mL} \mathrm{~min}^{-1}$ e $1,0 \mathrm{~mL} \mathrm{~min}{ }^{-1}$ e acetonitrila/água na proporção 90:10 (v/v) como fase móvel. 68

Figura 5.3 - Cromatograma de 4-Nonilfenol em coluna C-8 (Agilent ${ }^{\circledR}$ ) com fluxo de eluição de $0,8 \mathrm{~mL} \mathrm{~min}^{-1}$, para temperaturas de $35^{\circ} \mathrm{C}, 40^{\circ} \mathrm{C}$ e $45^{\circ} \mathrm{C}$ e acetonitrila/água na proporção de 90:10 (v/v) como fase móvel.

Figura 5.3 - Cromatograma do meio de cultura em coluna cromatográfica C-8 (Agilent ${ }^{\circledR}$ ) com fluxo de eluição de $0,8 \mathrm{~mL} \mathrm{~min}^{-1}$, temperatura de $40^{\circ} \mathrm{C}$ e acetonitrila/água na proporção 90:10 $(\mathrm{v} / \mathrm{v})$ como fase móvel. .70

Figura 5.4 - Cromatograma do 4-NF em água ultra purificada (coluna C-8), eluição isocrática com acetonitrila/água na proporção 90:10 (v/v), fluxo de 1,0 mL min ${ }^{-1}$, detector com comprimentos de onda em $220 \mathrm{~nm}\left(\lambda_{\text {exc }}\right)$ e $315 \mathrm{~nm}\left(\lambda_{\text {em }}\right)$ a $40^{\circ} \mathrm{C}$.

Figura 5.5 - Cromatogramas de 4-Nonilfenol sob diferentes volumes de Injeção para coluna cromatográfica C-8 (Agilent ${ }^{\circledR}$ ), temperatura de $40^{\circ} \mathrm{C}$, fluxo de eluição de $0,8 \mathrm{~mL} \mathrm{~min}^{-1}$ e acetonitrila/água na proporção de 90:10 (v/v) como fase móvel. 73 Figura 5.6 - Cromatogramas de 4-NF com variação dos comprimentos de onda do detector, para coluna cromatográfica C-8 $\left(\right.$ Agilent $\left.^{\circledR}\right)$, temperatura de $40^{\circ} \mathrm{C}$, volume de injeção de $100 \mu \mathrm{L}$, 
fluxo de eluição de $0,8 \mathrm{~mL} \mathrm{~min}^{-1}$ e acetonitrila/água na proporção de 90:10 (v/v) como fase móvel.

Figura 5.7 - Cromatogramas do método de extração em fase sólida para cartucho C18-ODS.

Figura 5.8 - Esquema de purificação de amostra em cartucho SPE C18-ODS..................... 78

Figura 5.9 - Curva analítica de quantificação de 4-Nonilfenol em HPLC. ........................... 80

Figura 5.10 - Produção acumulada de metano e ajuste ao modelo de Gompertz modificado nos ensaios controle e com adição de 4-Nonilfenol.

Figura 5.11 - Comparação entre Produção de Metano acumulada, Produção Teórica e percentual de conversão para todos os ensaios em reatores em batelada.

Figura 5.12 - Análise de cluster (Correlação de Pearson, UPGMA) do perfil das bandas do DGGE dos fragmentos do RNAr 16S para o Domínio Bacteria.

Figura 5.13 - Variação dos índices de riqueza e diversidade para o Domínio Bacteria em ensaios com reatores em batelada e inóculo.

Figura 5.14 - Variação dos índices de diversidade e dominância para o Domínio Bacteria em ensaios com reatores em batelada e inóculo.

Figura 5.15 - Análise de cluster (Correlação de Pearson, UPGMA) do perfil das bandas do DGGE dos fragmentos do rRNA 16S para o Domínio Archaea..

Figura 5.16 - Variação dos índices de diversidade e riqueza para o Domínio Archaea em ensaios com adição de 4-NF em reatores em batelada e inóculo. 98

Figura 5.17 - Variação dos índices de diversidade e dominância para o Domínio Archaea em ensaios em reatores em batelada e inóculo. 99

Figura 5.18 - Variação temporal de DQO afluente, efluente e eficiência de remoção. 103

Figura 5.19 - Representação em box-plot para DQO afluente, efluente (bruta e filtrada) e eficiências de remoção (bruta e filtrada) para cada fase de operação do RALF. 105

Figura 5.20 - Variação temporal da Carga Orgânica Volumétrica. 106 Figura 5.21 - Temperatura diária média, máxima e mínima durante as fases de operação do RALF. 108

Figura 5.22 - Representação em box-plot para pH (afluente e efluente) e alcalinidade total (afluente e efluente) para cada fase de operação do RALF. 110 Figura 5.23 - Representação em box-plot para alcalinidade parcial (afluente e efluente), alcalinidade intermediária (afluente e efluente) e relação AI/AP (afluente e efluente) para cada fase de operação do RALF. 
Figura 5.24 - Redução/Aumento percentual dos valores Efluente para pH, Alcalinidade parcial (AP), Alcalinidade Intermediária (AI) e Alcalinidade total (AT) para as fases de operação do RALF, em comparação aos valores Afluente.

Figura 5.25 - Variação temporal de 4-Nonilfenol aflu., eflu. e eficiência de remoção.

Figura 5.26 - Representação em box-plot para 4-NF afluente, efluente e eficiência de remoção para as fases operacionais do RALF.

Figura 5.27 - Distribuição percentual do balanço de massa de 4-Nonilfenol.

Figura 5.28 - Distribuição percentual do balanço de massa em cada fase operacional e carga diária de 4-NF aplicada.

Figura 5.29 - Valores médios de Sólidos Totais Voláteis (STV) do material suporte (areia) para as fases de operação do RALF.

Figura 5.30 - Microscopia eletrônica de varredura do grão de areia isento de biofilme (aumento $150 X)$

Figura 5.31 - Microscopia eletrônica de varredura da areia isenta de biofilme (A) (aumento 1000X) com detalhe para as microvilosidades da superfície (A1); e areia retirada do leito do reator (B) (aumento 1000X) após 102 dias de operação (Fase II), com detalhe para microvilosidade preenchida com biofilme (B1).

Figura 5.32 - Microscopia eletrônica de varredura dos microrganismos observados na areia do leito do reator após 102 dias de operação (aumento 5.000X). (1) bacilos; (2) cocobacilos... 121 Figura 5.33 - Microscopia eletrônica de varredura das vilosidades da areia do leito do reator após 102 dias de operação (aumento 10.000X) com arranjo microbiano em feixe.

Figura 5.34 - Fotografias do leito do RALF: (A) anterior a sua inoculação; (B) após 102 dias de operação; (B1) leito granular formado sobre o leito de areia.

Figura 5.35 - Microscopia eletrônica de um grão de areia coberto por biofilme (aumento 150X), retirado do leito granular do RALF após 102 dias de operação.

Figura 5.36 - Microscopia eletrônica de varredura do biofilme do grânulo: (A1) aglomerado celular do interior do biofilme (aumento 5.000X); (B1) aglomerado celular coberto por exopolímero; (B2) exopolímero.

Figura 5.37 - Análise de cluster (Correlação de Pearson, UPGMA) do perfil das bandas do DGGE dos fragmentos do RNAr 16S para o Domínio Bacteria de amostras do Inóculo, Fase I, II, III e IV do RALF.

Figura 5.38 - Variação dos Índices de diversidade e riqueza para o Domínio Bacteria em todas as fases de operação do RALF. 126 
Figura 5.39 - Variação dos Índices de diversidade e dominância para o Domínio Bacteria em todas as fases de operação do RALF e inóculo.

Figura 5.40 - Análise de cluster (Correlação de Pearson, UPGMA) do perfil das bandas do DGGE dos fragmentos do RNAr 16S para o Domínio Archaea de amostras do Inóculo, Fase I, II, III e IV do RALF. 128

Figura 5.41 - Variação dos Índices de diversidade e riqueza para o Domínio Archaea em todas as fases de operação do RALF e inóculo. 130

Figura 5.42 - Variação dos Índices de diversidade e dominância para o Domínio Archaea em todas as fases de operação do RALF e inóculo.

Figura 5.43 - Curva de rarefação (similaridade de 95\%) das sequências de amostra do Inóculo (A) Fase I (B), Fase III (B) e Grânulos (C) do RALF. 133

Figura 5.44 - Percentual de gêneros do domínio Archaea e Bacteria identificados em amostra do Ínoculo e fases de operação do RALF. 134 Figura 5.45 - Abundância relativas dos filos identificados em amostra do Inóculo e RALF (Fase I, Fase III e Grânulos). 135 Figura 5.46 - Diagrama de Venn para presença de gêneros identificados em amostras de Inóculo, Fase I, Fase III e Grânulos. 137

Figura 5.47 - Diagrama de Venn para presença de gêneros identificados com abundância relativa superior a 1\%, em amostras de Inóculo, Fase I, Fase III e Grânulos. 138

Figura 5.48 - Representação circular dos dez gêneros com maior abundância relativas para Inóculo, Leito de Areia sem adição de 4-Nonilfenol (Fase I), Leito de Areia após adição de 4NF (Fase III) e Leito com aspecto Granular com adição de 4-Nonilfenol (Grânulos).

Figura 5. 49 - Abundância relativa dos gêneros identificados no lodo de Inóculo (Inóculo) e no Leito de Areia sem adição de 4-Nonilfenol (Fase I). 141

Figura 5.50 - Abundância relativa dos gêneros identificados no Leito de Areia sem adição de

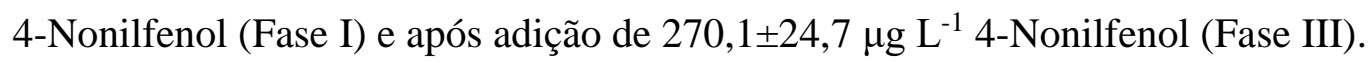
143 Figura 5.51 - Abundância relativa dos gêneros identificados após adição de $270,1 \pm 24,7 \mu \mathrm{g} \mathrm{L}^{-1}$ 4-Nonilfenol para amostra do Leito de Areia (Areia, Fase III) e no Leito com aspecto granular (Grânulos, Fase III). 148

Figura 5.52 - Variação dos Índices de diversidade e riqueza para o Domínio Bacteria. ...... 153 Figura 5.53 - Variação dos Índices de diversidade e dominância para o Domínio Bacteria. 154 Figura 5.54 - Variação dos Índices de diversidade e riqueza para o Domínio Archaea. ...... 155 Figura 5.55 - Variação dos Índices de diversidade e riqueza para o Domínio Archaea em amostras de sequenciamento massivo $16 \mathrm{~S}$ via plataforma Illumina-MiSeq ${ }^{\circledR}$. 156 


\section{LISTA DE TABELAS}

Tabela 3.1 - Efeitos do 4-NF em organismos teste................................................................. 39

Tabela 3.2 - Efeitos do 4-NF em humanos e animais............................................................ 40

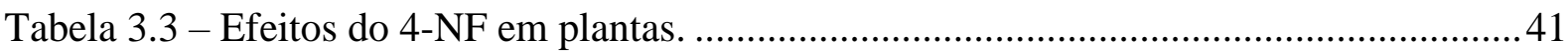

Tabela 3.4 - Ocorrência de 4-Nonilfenol em águas doces superficiais e sedimentos..............42

Tabela 3.5 - Ocorrência de 4-Nonilfenol em ETE................................................................. 43

Tabela 3.6 - Ocorrência de 4-Nonilfenol em ETE do Iran. ....................................................4

Tabela 3.7 - Pesquisas sobre remoção de surfactantes (LAS e LAE) realizadas no Laboratório de Processos Biológicos (LPB) em reator anaeróbio de leito fluidificado (RALF).................46

Tabela 4.3 - Propriedades físicas e químicas do 4-Nonilfenol...............................................48

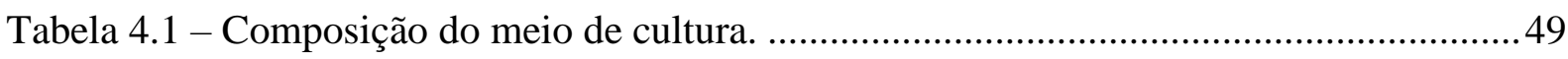

Tabela 4.2 - Composição da solução de sais para meio de cultura......................................... 49

Tabela 4.4 - Características da areia utilizada como material suporte ....................................53

Tabela 4.5 - Comprimentos de onda de excitação e emissão testados.....................................58

Tabela 4.6 - Cartuchos testados para extração em fase sólida (SPE). ......................................60

Tabela 4.7 - Análises de monitoramento do RALF e reator em batelada................................61

Tabela 5.1- Teste de detecção de 4-NF com variação de fase estacionária utilizando colunas cromatográficas C-8 (Agilent $\left.{ }^{\circledR}\right)$ e C-18 $\left(\right.$ Shimadzu $\left.^{\circledR}\right)$, para as temperaturas de $35^{\circ} \mathrm{C}, 40^{\circ} \mathrm{C}$ e $45^{\circ} \mathrm{C}$, fluxos de eluição de $0,5 \mathrm{~mL} \mathrm{~min}^{-1}, 0,8 \mathrm{~mL} \mathrm{~min}^{-1}$ e $1,0 \mathrm{~mL} \mathrm{~min}^{-1}$ e acetonitrila/água nas proporções 90:10 (v/v) como fase móvel. 66

Tabela 5.2 - Valores do teste de detecção de 4-NF com variação do volume de injeção, para coluna cromatográfica C-8 $\left(\right.$ Agilent $\left.^{\circledR}\right)$, temperatura de $40^{\circ} \mathrm{C}$, fluxo de eluição de $0,8 \mathrm{~mL} \mathrm{~min}{ }^{-1}$ e acetonitrila/água na proporção de 90:10 (v/v) como fase móvel.

Tabela 5.3 - Valores do teste de determinação de 4-NF com variação dos comprimentos de onda do detector, para coluna cromatográfica C-8 $\left(\right.$ Agilent $\left.^{\circledR}\right)$, temperatura de $40^{\circ} \mathrm{C}$, volume de Injeção de $100 \mu \mathrm{L}$, fluxo de eluição de $0,8 \mathrm{~mL} \mathrm{~min}^{-1}$ e acetonitrila/água na proporção de 90:10 (v/v) como fase móvel. 74

Tabela 5.4 - Percentual de adsorção de 4-NF em membranas de filtração.............................. 76

Tabela 5.5 - Recuperação de 4-NF em cartucho C18-ODS.................................................. 77 
Tabela 5.6 - Valores referentes ao sinal analítico médio, desvio padrão e desvio padrão relativo da curva analítica do 4-Nonilfenol.

Tabela 5.7 - DQO média inicial, final e eficiência de remoção.

Tabela 5.8 - Valores iniciais de pH, Alcalinidade Parcial, Intermediária e Total e Relação AI/AP.

Tabela 5.9 - Valores finais de pH, Alcali. Parcial, Intermediária e Total e Relação AI/AP... 86

Tabela 5.10 - Valores médios de 4-NF Inicial, Final e Eficiência de Remoção ..... 87

Tabela 5.11 - Parâmetros cinéticos para todos os ensaios em reatores em batelada. 88

Tabela 5.12 - Valores de produção teórica de $\mathrm{CH}_{4}$, produção observada e percentual de conversão.

Tabela 5.13 - Índices de diversidade para o Domínio Bacteria em ensaios com reatores em batelada e inóculo. 94

Tabela 5.14 - Índices de diversidade para o Domínio Archaea em ensaios com reatores em batelada e Inóculo. 97

Tabela 5. 15 - DQO média afluente, efluente e eficiência de remoção. 101

Tabela 5.16 - Valores médios de DQO bruta afluente, efluente e eficiência de remoção. ... 104

Tabela 5.17 - Valores médios de temperatura diária máxima, mínima e média. 107

Tabela 5.18 - Valores médios afluente e efluente de pH, Alcalinidade Parcial, Intermediária e Total e Relação AI/AP para as fases de operação do RALF. 109

Tabela 5.19 - Valores médios de 4-NF Afluente, Efluente, Eficiência de Remoção e comparação estatísticas para as fases de operação do RALF.

Tabela 5.20 - Valores de Sólidos Totais Voláteis (STV) do material suporte (areia) para as fases de operação do RALF. 118

Tabela 5.21 - Índices de diversidade para o Domínio Bacteria em todas as fases de operação do RALF. 125

Tabela 5.22 - Índices de diversidade para o Domínio Archaea em todas as fases de operação do RALF e inóculo.

Tabela 5.23 - Índices de diversidade para o Domínio Archaea em todas as fases de operação do RALF. 132

Tabela 5.24 - Índices de diversidade para o Domínio Bacteria via plataforma Illumina-MiSeq ${ }^{\circledR}$. 153

Tabela 5.25 - Índices de diversidade para o Domínio Archaea via plataforma Illumina-MiSeq ${ }^{\circledR}$. 


\section{LISTA DE ABREVIATURAS E SIGLAS}

4-NF para-Nonilfenol

ACN Acetonitrila

AI Alcalinidade intermediaria

AP Alcalinidade parcial

APHA American Public Health Association (Associação Americana de Saúde Pública)

CG Cromatografia gasosa

COV Carga Orgânica Volumétrica

DGGE Denaturing gradient gel electrophoresis (Eletroforese em gel de gradiente desnaturante)

DNA Ácido desoxirribonucleico

DQO Demanda química de oxigênio

EDTA Ácido etilenodiamino tetracético

EESC Escola de Engenharia de São Carlos

EGSB Expanded granular sludge-bed reactor (reator de leito granular expandido)

EPA US Environmental Protection Agency (Agência de Proteção Ambiental dos

Estados Unidos)

ETE Estação de tratamento de esgoto

FAPESP Fundação de Amparo à Pesquisa do Estado de São Paulo

HPLC High Performance Liquid Chromatography (Cromatografia Líquida de Alta Eficiência)

INMET Instituto Nacional de Meteorologia

LAS Alquilbenzeno linear sulfonado

LPB Laboratório de Processos Biológicos

$\mathrm{MeOH} \quad$ Metanol

MEV Microscopia eletrônica de varredura

NFe Nonilfenol Etoxilado

OTU Operational taxonomic unit (Unidade taxonômica organizacional)

PAH Polycyclic Aromatic Hydrocarbon (Hidrocarboneto aromático policíclico) 
PBS Tampão fosfato salino

PCR Polymerase chain reaction (Reação de polimerização em cadeia)

$\mathrm{pH} \quad$ Potencial hidrogeniônico

PVC Policloreto de vinila

RALF Reator Anaeróbio de Leito Fluidificado

RNAr Ácido ribonucléico ribossomal

SPE $\quad$ Extração em Fase Sólida (Solid Phase Extraction)

STV Sólidos totais voláteis

TDH Tempo de detenção hidráulico

UASB Upflow anaerobic sludge blanket (Reator anaeróbio de fluxo ascendente e manta de lodo)

UFSCar Universidade Federal de São Carlos

UPGMA Método de grupo de par não ponderado com médias aritméticas (Unweighted pair group method with arithmetic averages)

USP Universidade de São Paulo

UV Radiação ultravioleta 


\section{LISTA DE SÍMBOLOS}

\begin{tabular}{ll}
${ }^{\circ} \mathrm{C}$ & Graus Celsius \\
$\mathrm{CH}_{4}$ & metano \\
$\mathrm{CO}_{2}$ & dióxido de carbono, gás carbônico \\
$\mathrm{d}$ & Dia \\
$\mathrm{g}$ & Grama \\
$\mathrm{h}$ & Hora \\
$\mathrm{kg}$ & Quilograma \\
$\mathrm{kgf}$ & Quilograma força \\
$\mathrm{L}$ & Litro \\
$\mathrm{m}$ & Metro \\
$\mathrm{M}$ & Molar \\
$\mathrm{min}$ & Minuto \\
$\mathrm{mg}$ & Miligrama \\
$\mathrm{mL}$ & Mililitro \\
$\mathrm{N} 2$ & nitrogênio \\
$\mu \mathrm{g}$ & Micrograma \\
$\mu \mathrm{L}$ & Microlitro \\
$\mu \mathrm{m}$ & Micrômetro \\
$\mu \mathrm{mol}$ & Micromol \\
$\mathrm{ng}$ & Nanograma \\
$\mathrm{R}{ }^{2}$ & Coeficiente de determinação \\
$\mathrm{rpm}$ & Rotações por minuto \\
$\lambda \mathrm{exc}$ & Comprimento de onda de excitação (nm) \\
$\lambda \mathrm{em}$ & Comprimento de onda de emissão (nm) \\
\hline $\mathrm{V}$ & Volts
\end{tabular}





\section{SUMÁRIO}

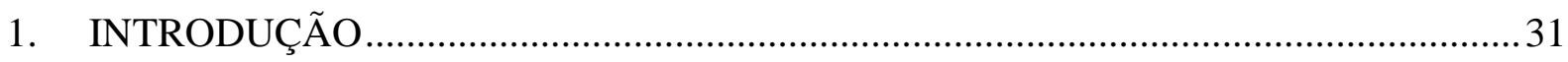

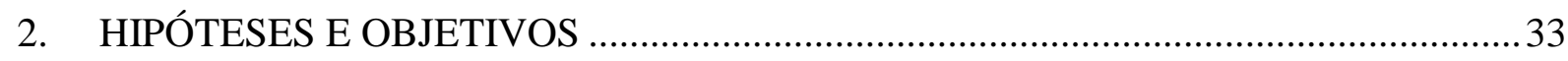

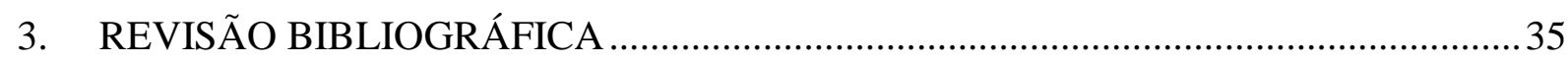

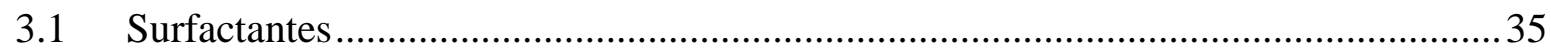

3.2 Risco Ambiental e Saúde Pública ...............................................................................

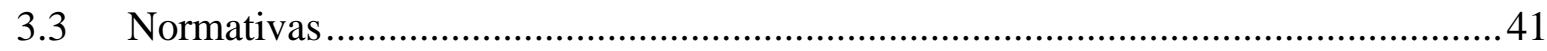

3.4 Ocorrência de 4-Nonilfenol em águas superficiais e sedimentos .................................42

3.5 Degradação de 4-Nonilfenol em ETE .....................................................................43

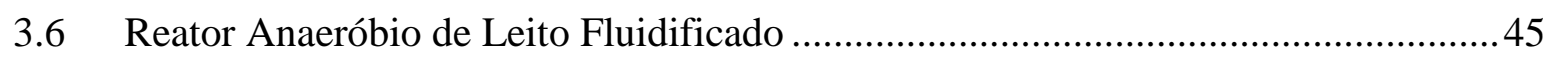

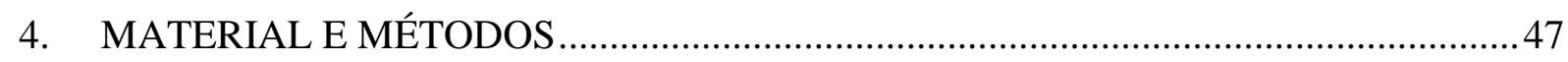

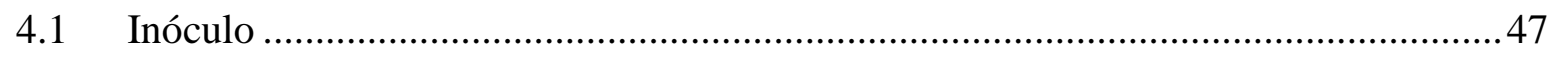

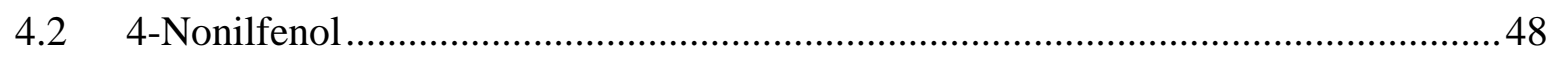

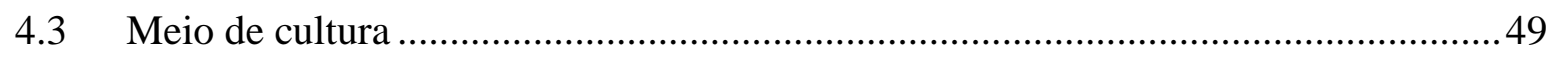

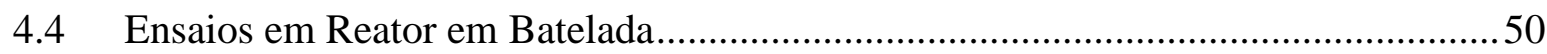

4.5 Reator Anaeróbio de Leito Fluidificado ………………..........................................51

4.6 Desenvolvimento de método analítico para quantificação de 4-NF ............................55

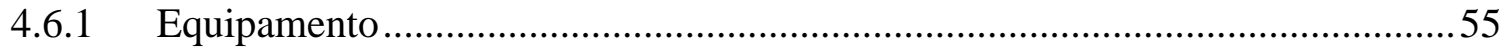

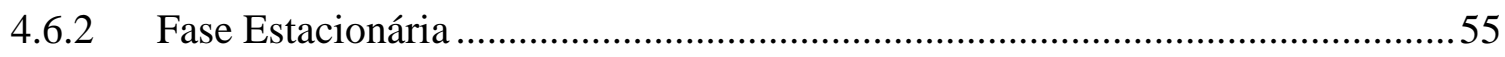

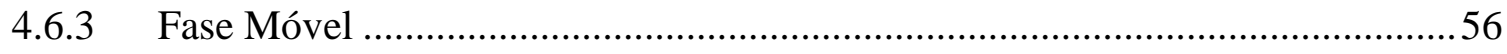

4.6.4 Preparo da Solução Padrão e meio de cultura …………………………………....56

4.6.5 Otimização dos Parâmetros Cromatográficos …………………………………...56

4.6.6 Validação do método ..................................................................................... 58

4.6.6.1 Seletividade.............................................................................................. 


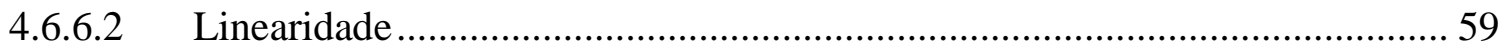

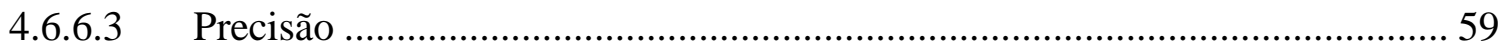

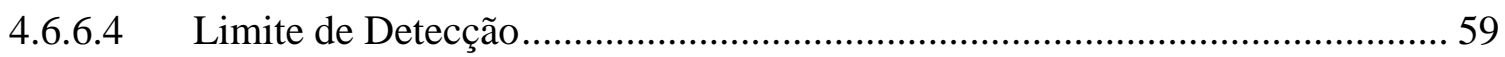

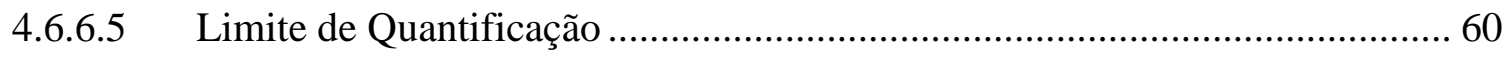

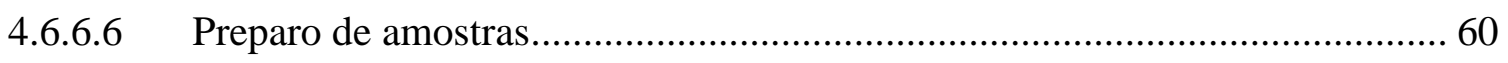

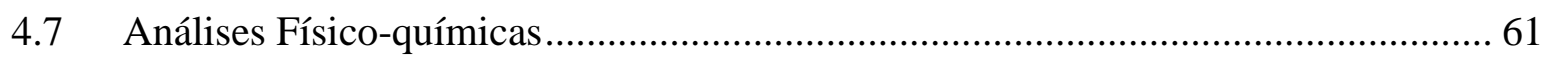

4.7.1 Extração de 4-Nonilfenol Adsorvido e Balanço de Massa ................................. 62

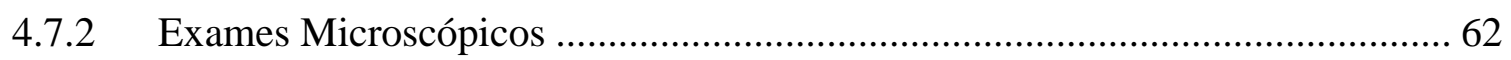

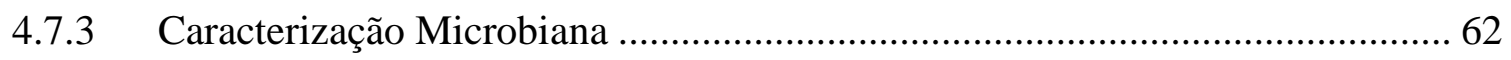

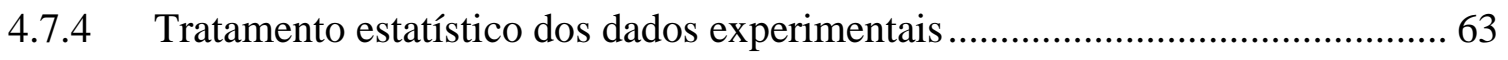

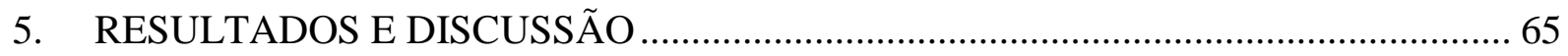

5.1 Desenvolvimento do método de quantificação o de 4-Nonilfenol ............................ 65

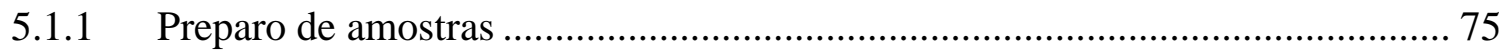

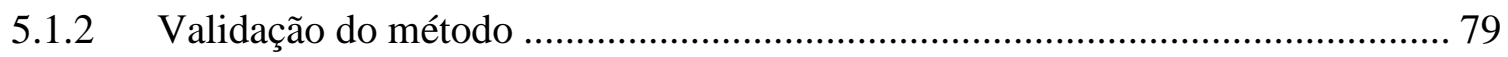

5.2 Ensaios em Reatores Anaeróbios em Batelada ............................................... 82

5.2.1 Remoção de matéria orgânica .................................................................... 82

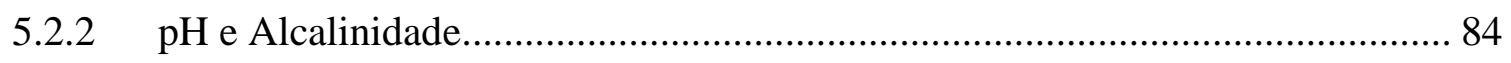

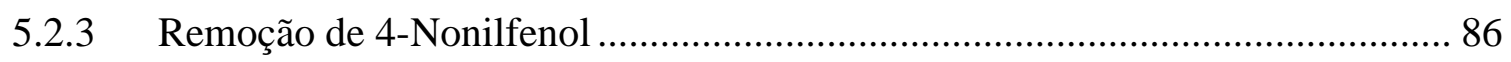

5.2.4 Potêncial metanogênico - Produção de $\mathrm{CH}_{4}$ e Parâmetros cinéticos .................. 88

5.2.5 Eletroforese em Gel com Gradiente Desnaturante (DGGE) ............................ 93

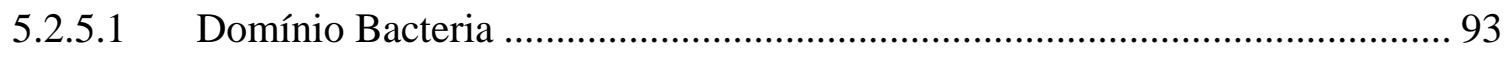

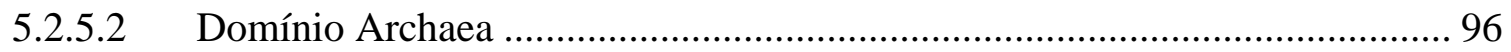

5.3 Monitoramento do reator de leito fluidificado ....................................................... 99

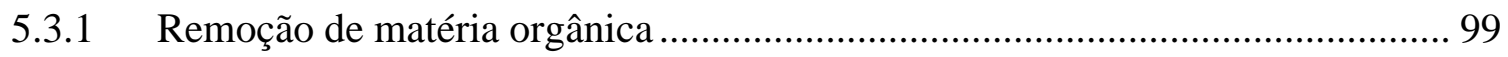

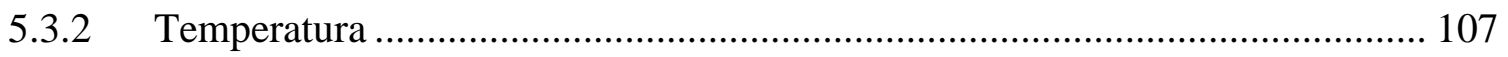

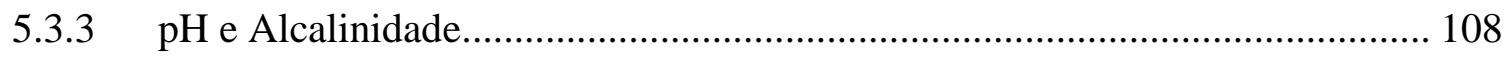

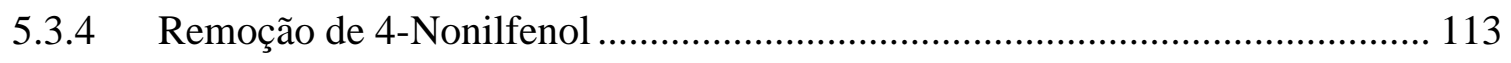




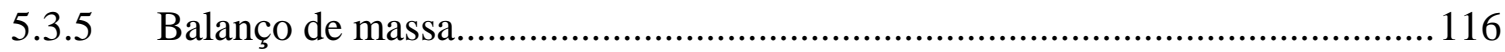

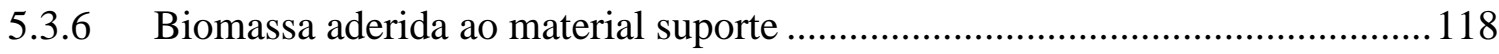

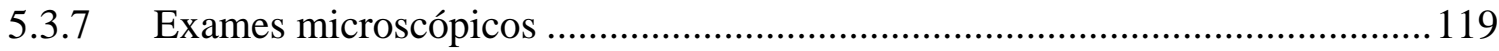

5.3.8 Eletroforese em Gel com Gradiente Desnaturante (DGGE) ........................... 124

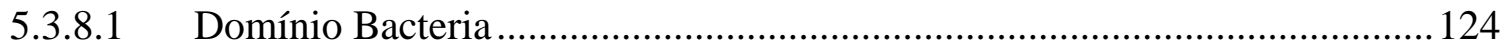

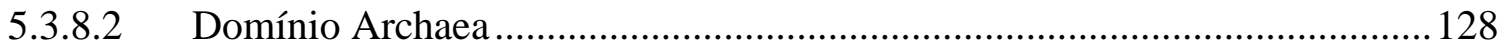

5.3.9 Caracterização microbiana Illumina MiSeq …................................................... 132

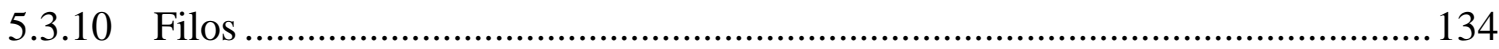

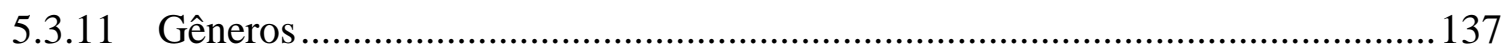

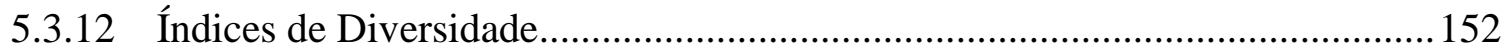

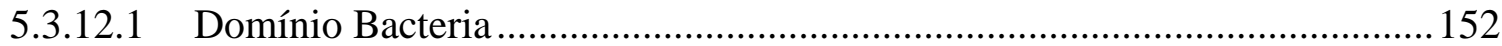

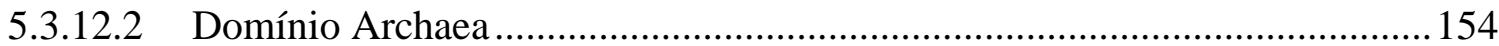

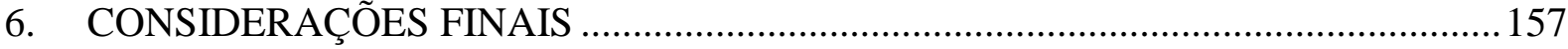

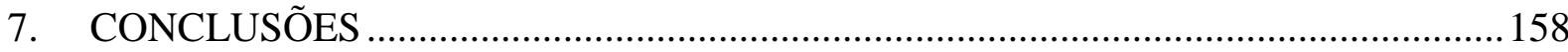

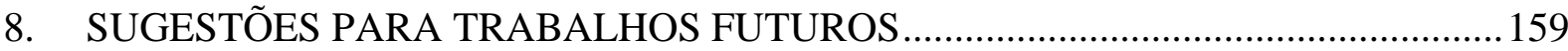

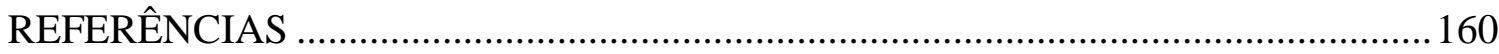





\section{INTRODUÇÃO}

Na composição da água residuária e esgoto sanitário tem-se ampla heterogeneidade de compostos químicos, o que reflete o alcance de substâncias de uso doméstico, fontes industriais e comerciais. O Relatório Internacional das Nações Unidas sobre o Desenvolvimento dos Recursos Hídricos é enfático em classificar as águas residuárias como um "Recurso Inexplorado". Para tanto, deve-se ampliar os esforços para garantir remoção e tratamento dos compostos tóxicos anteriormente ao lançamento no corpo receptor.

Nonilfenol etoxilado é um produto economicamente importante, uma vez que é amplamente utilizado na formulação de detergentes para limpeza doméstica, produtos de cuidados pessoais, têxteis, tintas, polímeros, formulações de pesticidas, farmacêuticas, mineração, recuperação de petróleo e indústrias de celulose e papel. A degradação deste composto gera produtos com características xenobióticas extremamente nocivas. O 4Nonilfenol é o principal produto formado a partir da degradação do Nonilfenol etoxilado. A sua presença no ambiente é diretamente relacionada as atividades antrópicas, como lançamento de efluentes em corpos receptores.

Em relação ao Nonilfenol etoxilado sabe-se da sua considerável persistência no ambiente e capacidade de bioacumulação. A sua toxicidade se dá principalmente pela habilidade de mimetizar o hormônio feminino $17 \beta$-estradiol, atuando como desregulador do sistema endócrino. $\mathrm{O}$ grau de periculosidade deste composto aumenta à medida que diminui o número de etoxilações, conferindo ao 4-Nonilfenol a maior toxicidade.

Já foi relatada a ocorrência do Nonilfenol etoxilado nas mais diferentes matrizes ambientais, tais como rios, estuários, sedimentos marinhos, chuva e neve. Além disso, foram relatados efeitos genotóxicos em organismos testes (Channa punctatus, Danio rerio, Salmo trutta caspius), plantas, ratos e células humanas.

Frente ao risco ambiental dos contaminantes emergentes e seus danos irreparáveis a curto e longo prazo, é evidente a necessidade de investigar a efetividade da remoção e degradação do 4-Nonilfenol em sistemas biológicos. 
Tecnologias biológicas podem ser empregadas com sucesso na degradação de contaminantes emergentes, como o 4-Nonilfenol. Ainda assim, têm-se poucos relatos sobre as condições de degradação do NP e seus precursores, bem como a interação deste com os demais componentes da água residuária em sistemas biológicos contínuos.

O Reator Anaeróbio de Leito Fluidificado (RALF) é alternativa tecnológica para remoção de contaminantes emergentes por oferecer vantagens como alta concentração de biomassa, diluição inicial do afluente e baixa resistência a transferência de massa. Ainda, temse para o RALF versatilidade operacional, a qual permite condicionar a espessura do biofilme por meio da velocidade de recirculação.

Essa configuração reacional já foi aplicada em muitas pesquisas do Laboratório de Processos Biológicos da EESC-USP, em especial para a degradação dos surfactantes Alquilbenzeno Linear Sulfonado (LAS) e Álcool Etoxilado (LAE), sendo verificada adequada remoção dos contaminantes, bem como redução da carga poluidora dos efluentes de lavanderias comerciais (CAROSIA et al., 2014; MOTTERAN et al., 2014a; MACEDO et al., 2015; ANDRADE et al., 2017; DELFORNO et al., 2017). Por meio dessas pesquisas tem-se indicativo dessa tecnologia com potencial de aplicação também para a remoção e degradação de outros surfactantes, tal como o 4-Nonilfenol.

A partir disso, o objetivo dessa pesquisa foi desenvolver método de quantificação de 4Nonilfenol por Cromatografia Líquida de Alta Eficiência (HPLC), avaliar o potencial metanogênico de lodo anaeróbio na presença de 4-NF em reatores em batelada; bem como sua remoção e degradação em reator anaeróbio de leito fluidificado com areia como material suporte. 


\section{HIPÓTESES E OBJETIVOS}

\section{Hipótese geral}

Por meio da aplicação do Reator Anaeróbio de Leito Fluidificado (RALF) com leito de areia será obtida a degradação e remoção de 4-Nonilfenol (4-NF) em meio de cultura.

\section{Objetivo Geral}

Avaliar a remoção e degradação do 4-Nonilfenol (4-NF) em meio de cultura e caracterizar a comunidade microbiana estabelecida no biofilme do RALF.

\section{Hipótese I}

A concentração de 4-NF afluente não afetará a eficiência de degradação da matéria orgânica.

\section{Objetivo I}

Avaliar a influência da concentração de 4-NF na eficiência de remoção de matéria orgânica durante as fases de operação do RALF.

\section{Hipótese II}

As diferentes concentrações de 4-NF aplicadas ao RALF ocasionarão seleção dos microrganismos que compõem sua biomassa.

\section{Objetivo II}

Avaliar a comunidade microbiana do RALF com e sem adição de 4-NF.

\section{Hipótese III}

Em função da concentração de 4-NF poderá ocorrer a inibição da metanogênese e redução da eficiência de remoção de matéria orgânica.

\section{Objetivo III}

Avaliar o potencial metanogênico do inóculo submetido a diferentes concentrações de NF em reatores anaeróbios em batelada. 


\section{Hipótese IV}

A adição de co-substrato ao meio de cultura pode contribuir para estabelecer comunidade microbiana degradadora de 4-NF.

\section{Objetivo IV}

Avaliar a eficiência de remoção e degradação de 4-NF em meio de cultura com adição de co-substrato.

\section{Hipótese V}

A comunidade microbiana do RALF pode degradar 4-NF em meio de cultura sem adição de co-substrato.

\section{Objetivo V}

Avaliar a eficiência de degradação de 4-NF em meio de cultura sem adição de cosubstrato.

\section{Hipótese VI}

A técnica de Cromatografia Líquida de Alta Eficiência (HPLC) pode ser empregada para identificação de 4-NF em estações de tratamento de águas residuárias.

\section{Objetivo VI}

Desenvolver metodologia em HPLC para quantificação de 4-NF em meio de cultura. 


\section{REVISÃO BIBLIOGRÁFICA}

\subsection{Surfactantes}

Os surfactantes estão incluídos em grupo diversificado de produtos químicos usados com a finalidade de reduzir a tensão superficial de líquidos ou interfaces, com propriedades de limpeza e solubilização. Os surfactantes podem ser constituídos por monômeros simples ou polímeros mais complexos. São formados por uma parte polar e uma cadeia de hidrocarbonetos não-polares, que não são facilmente dissolvidas em água. Assim, os surfactantes combinam propriedades hidrofóbicas e hidrofílicas na mesma molécula (NITSCHKE; PASTORE, 2002; YING, 2004; REBELLO et al., 2014).

Os surfactantes são divididos em três grupos a saber: aniônico, catiônico, não iônico e anfóteros. Dentre estes grupos, os frequentemente destinados ao uso comercial são o alquilbenzeno linear sulfonado (LAS), alquil etoxisulfato (AES), alquil sulfato (AS), alquilfenol etoxilado (AFE), alquil etoxilado (AE) e compostos de amônio quaternário (SALAGUER, 2002; YING, 2004).

O Nonilfenol Etoxilado (NFe) é um surfactante não iônico amplamente empregado na formulação de detergentes, lubrificantes, agente antiestático, agente de limpeza de têxteis de alto desempenho, pesticidas, antioxidante para produção de borracha e aditivo de óleo lubrificante (EPA, 2005).

Desde que o grupo Alquilfenol Polietoxilado foi sintetizado pela primeira vez em 1940, seu uso e produção tem aumentado exponencialmente (MANZANO et al., 1998; EPA, 2014a), sendo o NF, de longe, o membro mais prevalente comercialmente da família dos surfactantes não iônicos, representando $85 \%$ do mercado total (CORVINI; SCHÄFFER; SCHLOSSER, 2006; EPA, 2014a).

O 4-NF consiste em um grupo de nove carbonos ligados na posição para a um anel aromático (Figura 3.1). É produzido pela reação de catálise ácida do noneno com o fenol (THIELE et al., 2004; EPA, 2014a). 
Figura 3.1 - Estrutura química do 4-Nonilfenol.

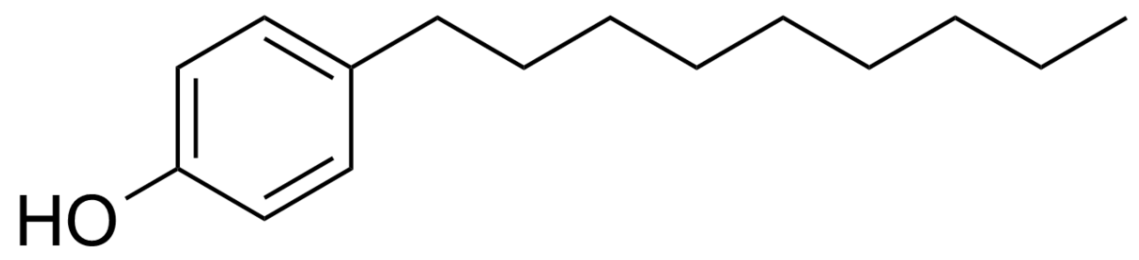

Fonte: Sigma-Aldrich (2015).

A principal fonte de 4-NF no ambiente é por meio da degradação de compostos de Nonilfenol etoxilados em Estações de Tratamento de Esgoto (ETE) (LANGFORD; LESTER, 2002). A medida que o NF é degradado, o número de carbonos da sua ramificação diminui, deixando os compostos gerados mais nocivos que seus precursores. Assim, a recalcitrância deste composto aumenta com a diminuição do número de grupos etoxilados (Nonilfenol polietoxilato < Nonilfenol dietoxilato < Nonilfenol monoetoxilato < 4-Nonilfenol) (SHAO; HU; YANG, 2003; SOARES et al., 2008).

A pressão de vapor e constante de Henry do 4-NF é de $2,07 \times 10^{-2} \mathrm{~Pa}$ e $8,39 \times 10^{-1} \mathrm{~Pa}$ $\mathrm{m}^{3} \mathrm{~mol}^{-1}$, respectivamente (NEY, 1990). Trata-se de um composto orgânico semi-volátil. Apesar disto, o 4-NF possui log de $K_{\text {ow }}$ de 4,48, que indica baixa solubilidade em água e afinidade a matéria orgânica, conferindo baixa mobilidade do meio líquido para o gasoso (SOARES et al., 2008). O 4-NF pode atingir a atmosfera por meio de aerossóis gerados em ETE e em sistemas de lodos ativados devido a intensa aeração (KE et al., 2017). Uma vez que atinge a atmosfera, o 4-NF pode ser transportado para o ambiente terrestre por meio de deposição úmida (chuva, neve) (FRIES; PÜTTMANN, 2004).

$\mathrm{Na}$ camada superficial das águas naturais sob radiação intensa, o 4-NF é rapidamente degradado (10 a 15 horas) devido à radiação solar, formando subprodutos (AHEL et al., 1994). A medida que estes subprodutos vão sendo degradados, compostos de cadeia menor são gerados e a hidrofobicidade do NF aumenta, favorecendo a sua adsorção em sedimentos. O tempo de vida do NF adsorvido em sedimentos é estimado em mais de 60 anos (SHANG; MACDONALD; IKONOMOU, 1999).

A ocorrência de 4-NF em ambientes aquáticos está relacionada com atividades antropogênicas, tendo como principal fonte o despejo de efluentes de ETE (AHEL; GIGER; SCHAFFNER, 1994; PETROVIC et al., 2002a; CORSI et al., 2003; FRIES; PÜTTMANN, 2004). Quando lançado no ambiente, este contaminante atinge as mais diversas matrizes, cujo risco ambiental e para a saúde pública é inestimável. 


\subsection{Risco Ambiental e Saúde Pública}

As preocupações a respeito do Nonilfenol Etoxilado emergiram pela primeira vez quando Giger; Brunner e Schaffner (1984), estabeleceram que os produtos de sua degradação (4-NF) eram mais tóxicos para a vida aquática do que seus precursores. Posteriormente, Soto et al. (1991) observaram a mimetização do 4-NF em estrogênio e atuação como desregulador do sistema endócrino, induzindo a proliferação de células de tumor mamário.

Os resultados obtidos por Soto et al. (1991) motivaram diversos pesquisadores a investigar os efeitos xenobióticos do 4-NP, levando vários grupos de pesquisa a confirmar a capacidade deste surfactante de mimetizar o hormônio feminino 17ß-estradiol (AHEL; GIGER; SCHAFFNER, 1994; DANZO, 1997; BALAGUER et al., 1999; BONEFELD-JØRGENSEN et al., 2007; SOARES et al., 2008; BECHI et al., 2010).

O 17ß-estradiol é um hormônio natural que influencia o desenvolvimento e a manutenção das características do sexo feminino (AREVALO; AZCOITIA; GARCIASEGURA, 2015). Devido a isso, o contato de organismos com o 4-NF desencadeia as mais diversas reações (UGUZ et al., 2009; SHIRDEL; KALBASSI, 2016; EL-HEFNAWY; HERNANDEZ; STABILE, 2017; SAYED; HAMED, 2017). Também, foi constatado por Lee et al. (2003), que o 4-NF desempenha atividade antiandrogênica entre 0,02 a 22,04 $\mu \mathrm{g} \mathrm{L}^{-1}$, sendo capaz de interferir no desenvolvimento do sexo masculino pela diminuição da produção de testosterona.

O 4-NF possui habilidade de ligação ao mesmos receptores que o $17 \beta$-estradiol, isso provoca competição pela ligação ao receptor de estrogênio (Figura 3.2 A), devido à similaridade da sua estrutura química (Figura 3.2 B). Ambos os compostos ativam as mesmas regiões funcionais para a síntese proteica, porém, diferentes respostas biológicas são desencadeadas na presença desses compostos (WHITE et al., 1994). 
Figura 3.2 - (A): Concorrência para o receptor de ligação de estrogênio entre 4-NF e 17ßestradiol na célula eucarionte (SOARES et al., 2008) e (B): comparação de estruturas químicas de $17 \beta$-estradiol e 4-NF.
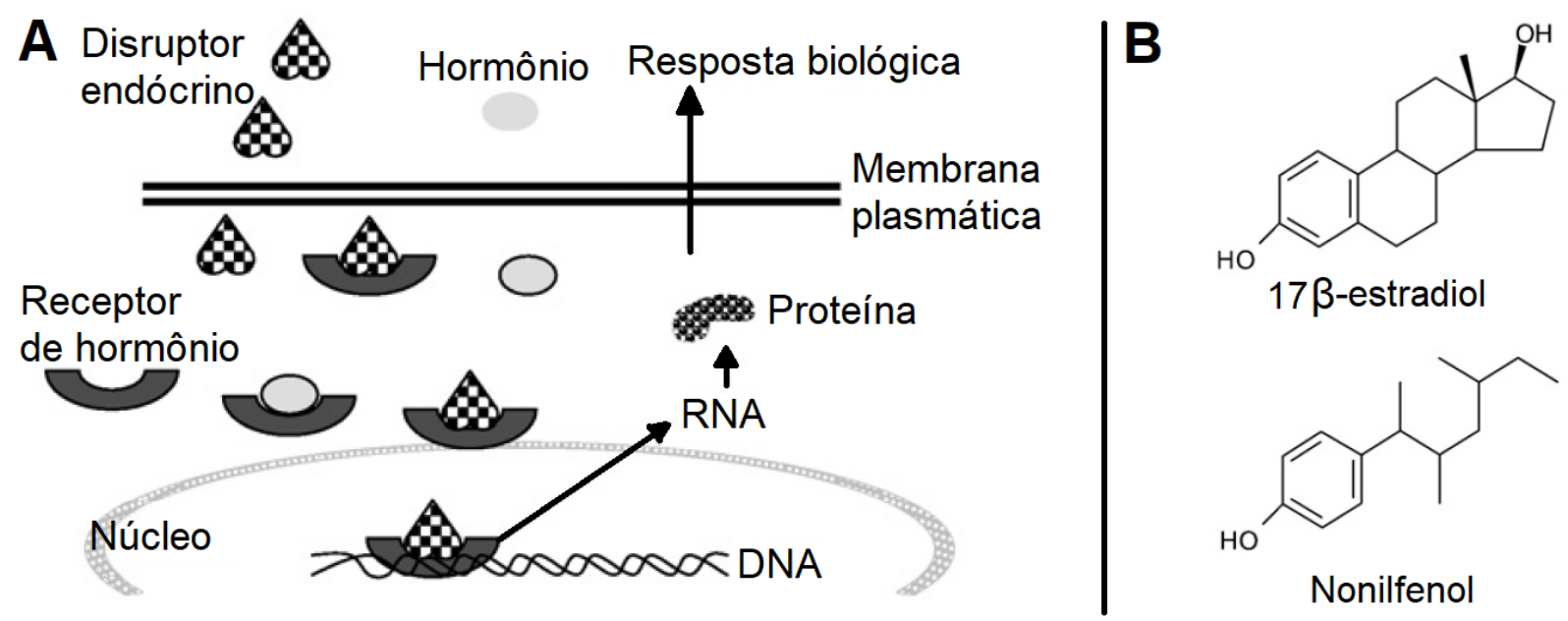

Fonte: adaptado de White et al., 1994.

Os seres humanos são expostos ao 4-NF, principalmente, por meio do consumo de alimentos cultivados com irrigação proveniente de manancial contaminado, ou pela ingestão direta de água contaminada. O 4-NF também é empregado na síntese de polímeros para a fabricação de recipientes plásticos e embalagens, os quais, dependendo das condições de uso, podem liberar NF para os alimentos e água. Outras vias de exposição humana incluem o contato com produtos de limpeza, higiene pessoal, bem como o uso de espermicidas em contraceptivos (PRIAC et al., 2014).

Loyo-Rosales et al. (2004) avaliaram a migração de Nonilfenol Etoxilado (NFe) em garrafas plásticas usadas para armazenamento de água para consumo. Foram adquiridas em supermercado garrafas de PEAD (polietileno de alta densidade), PET (polietileno tereftalato) e PVC (policloreto de vinila). Na água de consumo armazenada nas embalagens plásticas foi verificado concentrações de $\mathrm{NFe}$ de 180 a $300 \mathrm{ng} \mathrm{L}^{-1}$.

Os efeitos do 4-NF a diferentes organismos teste têm sido amplamente relatados. Sharma e Chadha (2017) verificaram alto dano ao DNA em órgãos do peixe Cabeça de Cobra (Channa punctatus), em doses de 150 a $630 \mu \mathrm{g} \mathrm{L}^{-1}$. Tang et al. (2017) relataram lesão nos testículos e redução da densidade de esperma do Peixe Zebra (Danio rerio), para doses de 150 $\mu \mathrm{g} \mathrm{L}^{-1}$. Alguns dos mais recentes efeitos reproduzidos em organismos podem ser verificados na Tabela 3.1. 
Tabela 3.1 - Efeitos do 4-NF em organismos teste.

\begin{tabular}{|c|c|c|c|}
\hline Indicador & Efeito & Dose & Referência \\
\hline $\begin{array}{l}\text { Oreochromi } \\
\text { s niloticus }\end{array}$ & $\begin{array}{l}\text { Aumento da frequência de estágios } \\
\text { reprodutivos }\end{array}$ & $0,032 \mathrm{ml} \mathrm{L}^{-1}$ & $\begin{array}{l}\text { Rivero et al. } \\
\qquad(2008)\end{array}$ \\
\hline $\begin{array}{l}\text { Heteropneu } \\
\text { stes fossilis }\end{array}$ & $\begin{array}{l}\text { Alta acumulação no cérebro, seguida de } \\
\text { brânquias, fígado, rim, ovário e } \\
\text { músculos }\end{array}$ & $64-164 \mu \mathrm{g} \mathrm{L}{ }^{-1}$ & $\begin{array}{l}\text { Gautam; } \\
\text { Chaube; Joy } \\
\text { (2015) }\end{array}$ \\
\hline $\begin{array}{l}\text { Salmo trutta } \\
\text { caspius }\end{array}$ & $\begin{array}{l}\text { Lesões em tecidos branquiais e tecido } \\
\text { intestinal }\end{array}$ & $1-100 \mu \mathrm{g} \mathrm{L}^{-1}$ & $\begin{array}{l}\text { Shirdel; } \\
\text { Kalbassi } \\
\text { (2016) }\end{array}$ \\
\hline $\begin{array}{l}\text { Channa } \\
\text { punctatus }\end{array}$ & $\begin{array}{l}\text { Alto dano ao DNA. Genotoxicidade em } \\
\text { brânquias, fígado e tecido renal }\end{array}$ & $150-630 \mu \mathrm{g} \mathrm{L}^{-1}$ & $\begin{array}{c}\text { Sharma; } \\
\text { Chadha (2017) }\end{array}$ \\
\hline $\begin{array}{l}\text { Coturnix } \\
\text { japonica }\end{array}$ & $\begin{array}{l}\text { Redução da capacidade reprodutiva e } \\
\text { lesão nas gônodas em organismos do } \\
\text { sexo masculino }\end{array}$ & $0,1-100 \mu \mathrm{g} \mathrm{L}^{-1}$ & $\begin{array}{l}\text { Cheng et al. } \\
\text { (2017) }\end{array}$ \\
\hline Danio rerio & $\begin{array}{l}\text { Lesão nos testículos e redução da } \\
\text { densidade de esperma }\end{array}$ & $150 \mu \mathrm{g} \mathrm{L}^{-1}$ & $\begin{array}{l}\text { Tang et al. } \\
\text { (2017) }\end{array}$ \\
\hline $\begin{array}{l}\text { Clarias } \\
\text { gariepinus }\end{array}$ & $\begin{array}{l}\text { Danos ao DNA e apoptose dos } \\
\text { eritrócitos }\end{array}$ & $100 \mu \mathrm{g} \mathrm{L}^{-1}$ & $\begin{array}{c}\text { Sayed; Hamed } \\
\text { (2017) }\end{array}$ \\
\hline
\end{tabular}

Os efeitos do 4-NF também têm sido avaliados em células e órgãos de humanos e ratos. Forte et al. (2016), verificaram em células da próstata humana, a desregulação do ciclo celular, ocasionando aumento da proliferação de células aberrantes com 0,22 $\mathrm{mg} \mathrm{L}^{-1}$ de 4-NF. Na Tabela 3.2 estão listados alguns dos mais recentes efeitos do 4-NF relatados em células/órgãos de humanos e ratos. 
Tabela 3.2 - Efeitos do 4-NF em humanos e animais.

\begin{tabular}{|c|c|c|c|}
\hline Ocorrência & Efeito & Dose & Referência \\
\hline $\begin{array}{l}\text { Esperma de } \\
\text { ratos }\end{array}$ & Redução da integridade acrosomal & $1 \mathrm{mg} \mathrm{L}^{-1}$ & $\begin{array}{l}\text { Uguz et al. } \\
\text { (2009) }\end{array}$ \\
\hline $\begin{array}{l}\text { Placenta } \\
\text { humana }\end{array}$ & $\begin{array}{l}\text { Redução da secreção de ocitocina, } \\
\text { podendo gerar complicações } \\
\text { durante a gestação }\end{array}$ & $0,022-220 \mathrm{ng} \mathrm{L}^{-1}$ & $\begin{array}{l}\text { Bechi et al. } \\
\text { (2010) }\end{array}$ \\
\hline $\begin{array}{l}\text { Células de } \\
\text { Leydig em } \\
\text { ratos }\end{array}$ & Inibição da liberação de testosterona & $0,94-28,09 \mathrm{mg} \mathrm{L}^{-1}$ & Wu et al. (2010) \\
\hline $\begin{array}{l}\text { Prostata } \\
\text { humana }\end{array}$ & $\begin{array}{l}\text { Aumento da proliferação de células } \\
\text { aberrantes. Desregulação do ciclo } \\
\text { celular }\end{array}$ & $0,22 \mathrm{mg} \mathrm{L}^{-1}$ & $\begin{array}{l}\text { Forte et al. } \\
\qquad(2016)\end{array}$ \\
\hline $\begin{array}{l}\text { Fígado de } \\
\text { ratos }\end{array}$ & $\begin{array}{l}\text { Redução da depuração do citosol } \\
\text { hepático, acumulação de estrogênio } \\
\text { e lesões no sistema reprodutivo }\end{array}$ & $0,1-3 \mathrm{mg} \mathrm{L}^{-1}$ & $\begin{array}{l}\text { El-Hefnawy; } \\
\text { Hernandez; } \\
\text { Stabile (2017) }\end{array}$ \\
\hline $\begin{array}{l}\text { Fígado de } \\
\text { ratos }\end{array}$ & $\begin{array}{l}\text { Desenvolvimento de doença } \\
\text { hepática gordurosa }\end{array}$ & $180 \mathrm{mg} \mathrm{kg} \mathrm{d}^{-1}$ & Yu et al. (2017) \\
\hline
\end{tabular}

Chen et al. (2008), observaram 1,82 a 211 ng de 4-NP g-1 de plasma em amostras de sangue de cordão umbilical de 174 fetos humanos. Neste estudo, as maiores concentrações foram detectadas em amostras de gestantes que residiam em zonas metropolitanas. Bechi et al. (2010) verificaram em células da placenta humana, que mesmo em baixas concentrações $(0,022$

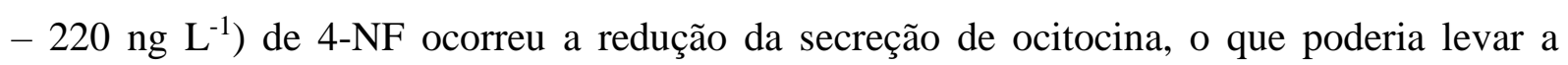
interrupção da gestação e outras complicações. A preocupação com os efeitos nocivos do 4-NF nas funções reprodutivas de humanos e animais fez com que autoridades internacionais tomassem medidas para regular o uso e lançamento deste contaminante em corpos receptores.

As plantas também estão sujeitas aos efeitos do 4-NF, como evidenciado por Esteban et al. (2016). Valores de 0,002 a $20 \mu \mathrm{g} \mathrm{L}^{-1}$ foram suficientes para provocar inibição da germinação e atividade mitocondrial em esporos de samambaia (Polystichum setiferum). Na Tabela 3.3 estão listados alguns dos mais recentes efeitos do 4-NF em plantas. 
Tabela 3.3 - Efeitos do 4-NF em plantas.

\begin{tabular}{llcc}
\hline \multicolumn{1}{c}{ Espécie } & \multicolumn{1}{c}{ Efeito } & \multicolumn{1}{c}{ Dose } & Referência \\
\hline Triticum & Fitotoxicidade, indicada por inibição da & & Zhang et al. \\
aestivum L. & $\begin{array}{l}\text { germinação, diminuição do } \\
\text { comprimento e espessura das raízes }\end{array}$ & $0,2-10 \mathrm{mg} \mathrm{L}^{-1}$ & $(2016)$ \\
Polystichum & Inibição da germinação e da atividade & $0,002-20 \mu \mathrm{g} \mathrm{L}^{-1}$ & $\begin{array}{c}\text { Esteban et al. } \\
\text { setiferum }\end{array}$ \\
& mitocondrial & & (2016) \\
Alface & Alterações na membrana plasmática & $0,8-12,8 \mathrm{mg} \mathrm{L}^{-1}$ & De Bruin et al. \\
& que comprometem sua funcionalidade & & (2017) \\
\hline
\end{tabular}

\subsection{Normativas}

Em 2002, o Conselho Canadense de Meio Ambiente estabeleceu uma norma de qualidade da água para a proteção da vida aquática de águas doces superficiais e ambientes marinhos, limitando a concentração de NF em 1 e $0,7 \mu \mathrm{g} \mathrm{L}^{-1}$, respectivamente, sem distinção de classes (CANADÁ, 2002).

O Parlamento Europeu classificou o 4-NF como "substância perigosa prioritária" (DIRECTIVA 2000/60/CE, 2000) e estabeleceu em 2003, limitações para seu uso. A Directiva 2003/53/CE (2003) restringe a colocação no mercado de substâncias com concentração superior a $0,1 \%$ de 4-NF e seus etoxilados, para usos em limpeza industrial ou doméstica, tratamento de têxteis e couro, trabalho de metais, emulsionante em produtos agrícolas, fabricação de pasta de papel, cosméticos e produtos de higiene pessoal, pesticidas e herbicidas (DIRECTIVA 2003/53/CE, 2003).

A Agência de Proteção Ambiental dos Estados Unidos (Environmental Protection Agency, EPA) propôs, em 2014, regras para uso deste surfactante e os demais compostos pertencentes ao grupo dos Alquilfenois Polietoxilados (EPA, 2014a). Em 2005, a Agência já havia proposto padrões de qualidade da água para a proteção da vida aquática, fixando as concentrações de 4-NF para água doce em $28 \mu \mathrm{g} \mathrm{L}^{-1}$ para exposição aguda e 6,6 $\mu \mathrm{g} \mathrm{L}^{-1}$ para exposição crônica. Em águas salinas a concentração máxima permitida é de $7 \mu \mathrm{g} \mathrm{L}^{-1}$ para exposição aguda e $1,7 \mu \mathrm{g} \mathrm{L}^{-1}$ para exposição crônica. Os critérios para o estabelecimento desses 
valores foram definidos com base em diversos testes ecotoxicológicos em organismos testes (peixes, crustáceos, plantas) (EPA, 2005).

No Brasil não há qualquer regulamentação acerca destes surfactantes, seja para padrões de potabilidade da água para consumo - Portaria do MS No 2.914/2011 (BRASIL, 2011a), ou lançamento de efluentes em corpos receptores - Resolução CONAMA N 430/2011 (BRASIL, 2011b).

\subsection{Ocorrência de 4-Nonilfenol em águas superficiais e sedimentos}

A presença de 4-NF em rios está diretamente relacionada ao lançamento de efluente tratado de estações de tratamento de esgoto (ETE) (LANGFORD; LESTER, 2002). O 4-NF tem sido detectado em rios em concentrações de 0,015 - 2,25 $\mu \mathrm{g} \mathrm{L}^{-1}$ (AHEL; GIGER; SCHAFFNER, 1994b) a $15 \mu \mathrm{g} \mathrm{L}^{-1}$ (PETROVIC et al., 2002a). Em sedimentos de rios as concentrações podem ser mais elevadas, chegando a $5.100 \mathrm{mg} \mathrm{kg}^{-1}$ (AHEL; GIGER; SCHAFFNER, 1994b). Na Tabela 3.4 estão delineadas as ocorrências de 4-NF em água doce superficial e sedimentos.

Tabela 3.4 - Ocorrência de 4-Nonilfenol em águas doces superficiais e sedimentos.

\begin{tabular}{cccc}
\hline \multirow{2}{*}{ País } & \multicolumn{2}{c}{ 4-Nonilfenol } & Referência \\
\cline { 2 - 3 } Suíça & Água Doce $\left(\mu \mathrm{g} \mathrm{L}^{-1}\right)^{*}$ & Sedimentos $\left(\mathrm{mg} \mathrm{Kg}^{-1}\right)^{*}$ & \\
Canadá & $0,015-2,25$ & 3520 & Ahel; Giger; Schaffner (1994) \\
Espanha & 15 & $0,17-72$ & Bennie et al. (1997) \\
Taiwan & $0,02-3,94$ & $0,022-0,645$ & Petrovic et al. (2002) \\
Espanha & 0,292 & $0,0066-47,8$ & Lee et al. (2013) \\
Espanha & $0,05-0,888$ & $0,47-1,693$ & Gorga et al. (2015) \\
China & 0,017 & $0,013-4,536$ & Salgueiro-González et al. (2015) \\
China & 0,157 & 0,124 & Wang et al. (2016) \\
China & 0,769 & 0,021 & Liu et al. (2016) \\
Espanha & - & $0,00043-0,047$ & Liu et al. (2017) \\
China & $0,233-3,353$ & $0,0075-0,0208$ & Pintado-Herrera et al. (2017) \\
China & 5,05 & 0,0144 & Diao et al. (2017) \\
\hline
\end{tabular}

*As unidades originais foram transformadas para fins de comparação. 


\subsection{Degradação de 4-Nonilfenol em ETE}

A remoção do 4-Nonilfenol e seus etoxilados tem sido investigada principalmente em condições aeróbias. Há poucos relatos que documentam as condições para a degradação destes compostos e seus produtos intermediários em tratamento biológico contínuo, especialmente para processos anaeróbios. A ocorrência de NF em ETE tem sido relatada em concentrações de 1,3 a $296 \mu \mathrm{g} \mathrm{L}^{-1}$ para afluente e de 0,6 a $90 \mu \mathrm{g} \mathrm{L} \mathrm{L}^{-1}$ para efluente final. Na Tabela 3.5 estão listadas algumas das ocorrências de 4-NF em ETE.

Tabela 3.5 - Ocorrência de 4-Nonilfenol em ETE.

\begin{tabular}{|c|c|c|c|c|}
\hline País & Fonte & $\begin{array}{c}\text { Concentração } \\
\left(\mu \mathrm{g} \mathrm{L}^{-1}\right)\end{array}$ & $\begin{array}{c}\text { Remoção média } \\
\text { final }(\%)\end{array}$ & Referência \\
\hline \multirow{2}{*}{ Suíça } & Efluente primário & 43,5 & \multirow{2}{*}{65,5} & \multirow{2}{*}{ Ahel et al. (1994a) } \\
\hline & Efluente Secundário & 15 & & \\
\hline \multirow{2}{*}{ Japão } & Efluente primário & 296 & \multirow{2}{*}{69,6} & \multirow{2}{*}{ Fujita et al. (2000) } \\
\hline & Efluente final & 90 & & \\
\hline \multirow{2}{*}{ Japão } & Afluente & $1,3-75$ & \multirow{2}{*}{98,7} & \multirow{2}{*}{ Nasu et al. (2001) } \\
\hline & Efluente & $0,1-0,9$ & & \\
\hline \multirow{2}{*}{ China } & Afluente & 9,3 & \multirow{2}{*}{84,2} & \multirow{2}{*}{ Shao; Hu; Yang (2003) } \\
\hline & Efluente final & 1,5 & & \\
\hline \multirow{2}{*}{ Iran } & Afluente & $3,78-5,57$ & \multirow{2}{*}{$62-93$} & \multirow{2}{*}{ Bina et al. (2017) } \\
\hline & Efluente & $0,6-2,12$ & & \\
\hline \multirow{2}{*}{ China } & Afluente & $3,9-7$ & \multirow{2}{*}{78} & \multirow{2}{*}{ Gao et al. (2017) } \\
\hline & Efluente & 2 & & \\
\hline
\end{tabular}

Gao et al. (2017), estudaram a eficiência de remoção de 4-NF em esgoto sanitário, em sistema de tratamento composto por tanque anaeróbio seguido de anóxico, em TDH de 19 dias, cuja concentração observada foi de $2 \mu \mathrm{g} \mathrm{L} \mathrm{L}^{-1}$ de 4-NF no efluente final.

Alguns pesquisadores apontam o potencial de aplicação de processos como ozonização e radiação UV para remoção de 4-NF em ETE (FELIS; MIKSCH, 2015), porém, esta tecnologia 
tem alto custo de implantação e demanda manutenção periódica e operadores com formação especializada (LEVERENZ; DARBY; TCHOBANOGLOUS, 2006). O tratamento biológico pode ser alternativa viável para remoção de surfactantes não iônicos e compostos relacionados que persistem no esgoto sanitário (BERTIN et al., 2007).

Devido ao seu caráter hidrofóbico o 4-NF tende a se acumular no lodo de ETE, por isso, Murdoch e Sanin (2016) monitoraram a degradação de Nonilfenol dietoxilado, Nonilfenol monoetoxilado e Nonilfenol em digestores de lodo em escala de bancada. Os seis digestores com 21 litros cada, foram operados em condições mesofílicas anaeróbias, com alimentação em bateladas sequenciais, juntamente com o monitoramento simultâneo do desempenho do digestor durante 80 dias de operação. Os autores verificaram que à presença de NF não influenciou no desempenho do digestor. Além disso, verificaram também que a concentração de 4-NF aumentou (de $150 \mu \mathrm{g} \mathrm{L}^{-1}$ para $360 \mu \mathrm{g} \mathrm{L}^{-1}$ ) durante o período operacional, devido a degradação de seus precursores Nonilfenol dietoxilado (de $400 \mu \mathrm{g} \mathrm{L} \mathrm{L}^{-1}$ para $60 \mu \mathrm{g} \mathrm{L}^{-1}$ ) e monoetoxilado (de $250 \mu \mathrm{g} \mathrm{L}^{-1}$ para $160 \mu \mathrm{g} \mathrm{L}^{-1}$ ).

Bina et al. (2017) avaliaram a concentração de 4-NF em ETE do Iran com sistemas de lodos ativados, lodos ativados + wetlands e lodos ativados com leito móvel e observaram eficiências de remoção de $62 \%$ a $93 \%$ para afluentes de 1,25 a $17,02 \mu \mathrm{g} \mathrm{L} \mathrm{L}^{-1}$, conforme Tabela 3.6 .

Tabela 3.6 - Ocorrência de 4-Nonilfenol em ETE do Iran.

\begin{tabular}{cccc}
\hline \multirow{2}{*}{ Tratamento } & \multicolumn{2}{c}{ 4-Nonilfenol $\left(\mu \mathrm{g} \mathrm{L}^{-1}\right)$} & \multirow{2}{*}{ Eficiência (\%) } \\
\cline { 2 - 3 } & Afluente & Efluente & \\
\hline Lodo ativado & 4,1 & 0,768 & 81,27 \\
Lodo ativado & 3,78 & 0,605 & 83,99 \\
Lodo ativado & 4,72 & 0,924 & 80.42 \\
Lagoa aerada & 5,57 & 2,12 & 61.94 \\
Lagoa aerada & 2,56 & 0,932 & 63,59 \\
Lagoa aerada & 1,25 & 0,42 & 66.40 \\
Lodo ativado + Wetlands & 17,02 & 1,163 & 93.17 \\
Lodo ativado & 4,02 & 0,807 & 79.93 \\
Lodo ativado com leito móvel & 8,23 & 0,671 & 91.85 \\
\hline
\end{tabular}


O tratamento biológico pode ser empregado com sucesso na degradação de contaminantes emergentes, como o 4-NF. Apesar disto, há poucos relatos sobre as condições de degradação do NF e seus precursores, bem como a interação deste com os demais componentes da água residuária em tratamento biológico contínuo.

\subsection{Reator Anaeróbio de Leito Fluidificado}

A tecnologia de leito fluidificado é usada desde 1970, principalmente para tratamento de água residuárias industriais, e já foi considerada uma das mais recentes inovações tecnológicas para o tratamento de esgoto (BURGHATE; INGOLE, 2013; KARADAG et al., 2015; BELLO; RAMAN; PURUSHOTHAMAN, 2017).

O Reator Anaeróbio de Leito Fluidificado (RALF), possui concepção vertical com fluxo ascendente de massa líquida, que promove a dispersão das partículas sólidas que servem de suporte para adesão dos microrganismos responsáveis pela degradação da matéria orgânica (METCALF; EDDY, 2003).

As principais vantagens da tecnologia de fluidificação, oferecidas ao tratamento de esgoto e água residuária, são a alta concentração de biomassa aderida ao meio suporte; alta área superficial para a fixação de biomassa; diluição inicial do afluente com o efluente, que proporciona alcalinidade e reduz efeitos de choque; baixa resistência a transferência de massa e possibilidade de controlar e otimizar a espessura do biofilme ( METCALF; EDDY, 2003; DENG et al., 2016; BELLO; ABDUL RAMAN; PURUSHOTHAMAN, 2017).

Diversas pesquisas foram realizadas no Laboratório de Processos Biológicos (LPB) da EESC-USP, acerca da degradação do surfactante LAS e LAE em reatores anaeróbios de leito fluidificado (OLIVEIRA et al., 2010; CAROSIA et al., 2014; MOTTERAN et al., 2014a; BRAGA et al., 2015; DELFORNO et al., 2015; MACEDO et al., 2015), e em todas as pesquisas, verificou-se adequada remoção do contaminante bem como redução da carga poluidora dos efluentes de lavanderias comerciais, as quais podem ser verificadas na Tabela 3.7. 
Tabela 3.7 - Pesquisas sobre remoção de surfactantes (LAS e LAE) realizadas no Laboratório de Processos Biológicos (LPB) em reator anaeróbio de leito fluidificado (RALF).

\begin{tabular}{|c|c|c|c|c|c|}
\hline Referência & $\begin{array}{l}\text { OLIVEIRA } \\
\text { et al. (2010) }\end{array}$ & $\begin{array}{l}\text { CAROSIA } \\
\text { et al. (2014) }\end{array}$ & $\begin{array}{l}\text { MOTTERAN } \\
\text { et al. (2014) }\end{array}$ & $\begin{array}{c}\text { BRAGA } \\
\text { et al. (2015) }\end{array}$ & $\begin{array}{l}\text { MACEDO et } \\
\text { al. (2015) }\end{array}$ \\
\hline Reator & RALF & RALF & RALF & RALF & RALF \\
\hline TDH (h) & 18 & 15 & 18 & 19 & 18 \\
\hline Duração(Dias) & 100 & 231 & 492 & 489 & 330 \\
\hline $\begin{array}{l}\text { Temperatura } \\
\left({ }^{\circ} \mathrm{C}\right)\end{array}$ & 30 & 30 & 30 & 30 & 30 \\
\hline Alimentação & $\begin{array}{l}\text { Extrato de } \\
\text { levedura e } \\
\text { sacarose }\end{array}$ & $\begin{array}{l}\text { Extrato de } \\
\text { levedura e } \\
\text { etanol }\end{array}$ & $\begin{array}{l}\text { Extrato de } \\
\text { levedura e } \\
\text { sacarose }\end{array}$ & $\begin{array}{l}\text { Extrato de } \\
\text { levedura, } \\
\text { sacarose e } \\
\text { água de } \\
\text { lavanderia }\end{array}$ & $\begin{array}{l}\text { Extrato de } \\
\text { levedura, } \\
\text { sacarose e } \\
\text { etanol }\end{array}$ \\
\hline $\begin{array}{l}\text { DQO afluente } \\
\left(\mathrm{mg} \mathrm{L}^{-1}\right)\end{array}$ & $632 \pm 42$ & $607 \pm 60$ & $735 \pm 87$ & $686 \pm 92$ & $705,0 \pm 155,8$ \\
\hline $\begin{array}{l}\text { DQO efluente } \\
\left(\mathrm{mg} \mathrm{L}^{-1}\right)\end{array}$ & $60 \pm 17$ & $87 \pm 33$ & $49,7 \pm 18$ & $61 \pm 22$ & $75,8 \pm 41,0$ \\
\hline Eficiência (\%) & $91 \pm 2$ & $85,8 \pm 4,9$ & $93 \pm 2$ & $90,9 \pm 13,0$ & $89,2 \pm 5,4$ \\
\hline Surfactante & LAS* & LAS & $\mathrm{LAE}^{* *}$ & LAS & LAS \\
\hline $\begin{array}{l}\text { Afluente } \\
\left(\mathrm{mg} \mathrm{L}^{-1}\right)\end{array}$ & $45,8 \pm 5,4$ & $14,4 \pm 3,5$ & $4,7-107,4$ & $23,3 \pm 5,5$ & $25,4 \pm 8,8$ \\
\hline $\begin{array}{l}\text { Efluente } \\
\left(\mathrm{mg} \mathrm{L}^{-1}\right)\end{array}$ & $3,2 \pm 1,2$ & $7,5 \pm 2,2$ & $0,01-2,6$ & $8,27 \pm 4,45$ & $6,0 \pm 3,8$ \\
\hline Eficiência (\%) & $93 \pm 3$ & $47,6 \pm 10,2$ & $97 \%-99 \%$ & $65,3 \pm 14,3$ & $72,9 \pm 18,8$ \\
\hline
\end{tabular}

Por meio destas pesquisas obteve-se indicativo das diferentes condições de operação do RALF e consequente aplicação para a degradação de outros surfactantes, como por exemplo o Nonilfenol Etoxilado (NFe) e seu principal subproduto 4-Nonilfenol (4-NF). 


\section{MATERIAL E MÉTODOS}

A execução desta pesquisa foi dividida em três etapas distintas, a saber: Desenvolvimento de metodologia em HPLC; Testes em reatores em batelada e Operação de reator contínuo RALF; conforme delineado no fluxograma geral da Figura 4.1.

Figura 4.1 - Fluxograma geral das etapas de execução do projeto.
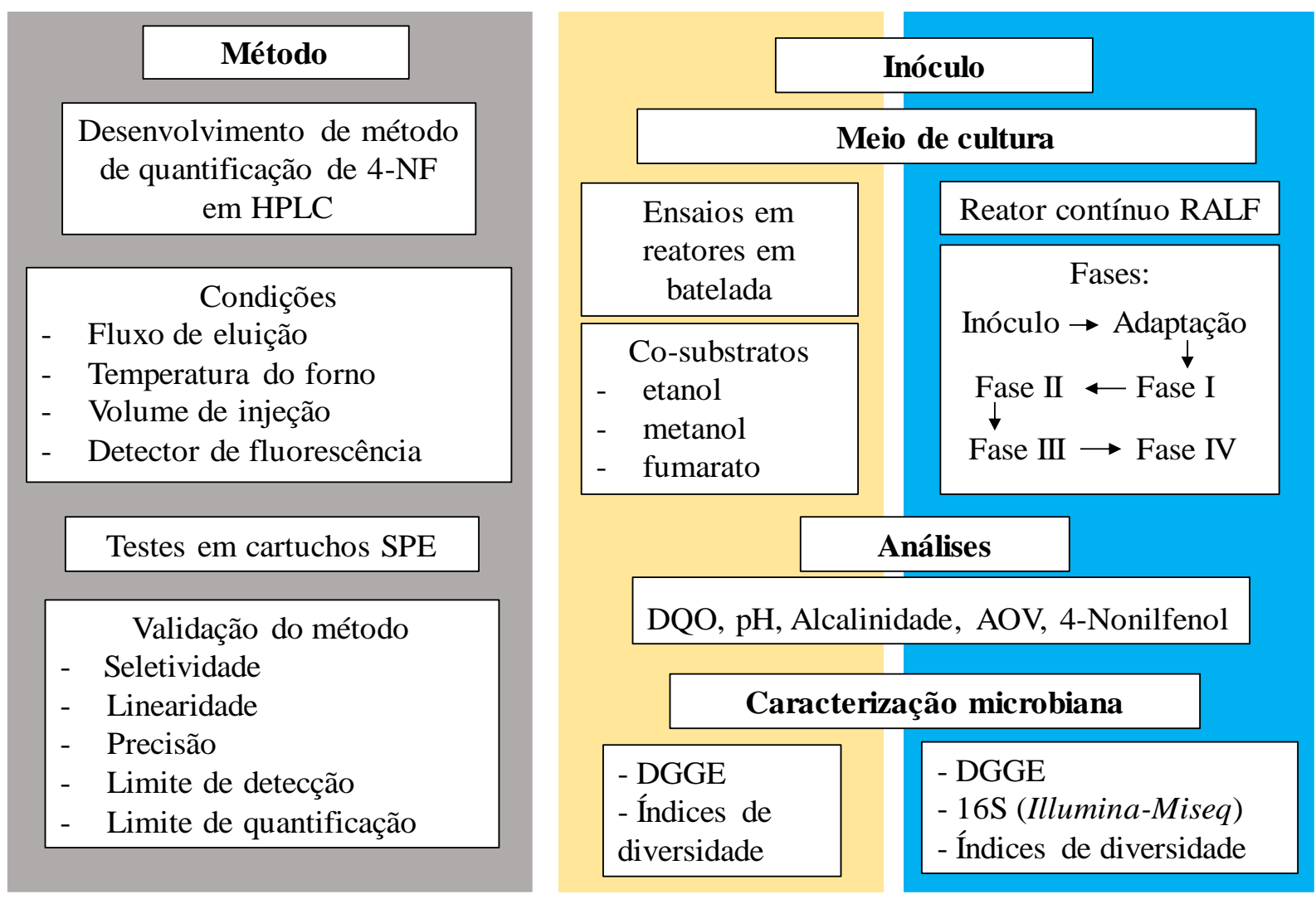

Fonte: $\mathrm{O}$ autor.

\subsection{Inóculo}

O lodo anaeróbio usado para inoculação do RALF e dos reatores em batelada foi proveniente de reator UASB usado no tratamento de água residuária de abatedouro de aves (Pereira, São Paulo). Tal lodo foi escolhido devido aos bons resultados obtidos em trabalhos 
anteriores na degradação de surfactante aniônico (LAS) (DUARTE et al., 2006; OLIVEIRA et al., 2010). Antes de ser usado, o lodo foi armazenado em câmara fria a $4{ }^{\circ} \mathrm{C}$.

Para inoculação dos reatores em batelada o lodo passou por processo de esgotamento, condicionado a $30{ }^{\circ} \mathrm{C}$ durante dez dias a fim de exaurir as fontes de carbono provenientes da água residuária a qual o lodo originou. A produção acumulada de metano foi monitorada até estabilização, indicando o total consumo das fontes de carbono solúveis. A concentração de sólidos totais voláteis - STV $\left(36,6 \pm 1,5 \mathrm{~g} \mathrm{~L}^{-1}\right)$ ao final do processo de esgotamento foi usada para calcular a diluição necessária para garantir uma concentração de $2 \mathrm{~g} \mathrm{STV} \mathrm{L}^{-1}$ nos reatores em batelada.

Para a inoculação do RALF, o lodo granular com uma concentração de STV de 40,2 $\pm 0,1$ $\mathrm{g} \mathrm{L}^{-1}$ foi desestruturado afim de garantir que não houvesse colmatação ${ }^{1}$ do leito de areia devido aos grânulos.

\subsection{4-Nonilfenol}

$\mathrm{Na}$ alimentação dos reatores em batelada e reator contínuo de leito fluidificado foi usado 4-NF padrão (Sigma-Aldrich ${ }^{\circledR}$, CAS n $^{\circ}$ 104-40-5). As propriedades físicas e químicas do 4-NF usado estão apresentadas na Tabela 4.1.

Tabela 4.1 - Propriedades físicas e químicas do 4-Nonilfenol.

\begin{tabular}{cc}
\hline Propriedades & Valor \\
\hline CAS N & $104-40-5$ \\
PubChem Substance ID & 329757165 \\
Massa Molecular $\left(\mathrm{g} \mathrm{mol}^{-1}\right)$ & 220,35 \\
Fórmula & $\mathrm{C}_{15} \mathrm{H}_{24} \mathrm{O}$ \\
Densidade $\left(\mathrm{g} \mathrm{mL}^{-1}\right.$ a $\left.20^{\circ} \mathrm{C}\right)$ & 0,6 \\
Ponto de Fusão $\left({ }^{\circ} \mathrm{C}\right)$ & -10 \\
Ponto de Ebulição $\left({ }^{\circ} \mathrm{C}\right)$ & 113 \\
pKa & 10,7 \\
Solubilidade em água $\left(\mathrm{mg} \mathrm{L}^{-1}\right)$ & 4,90 \\
Pressão de Vapor Pa $\left(20^{\circ} \mathrm{C}\right)$ & $1,33 \mathrm{~Pa}$ \\
Log Kow & $4,36-4,60$ \\
\hline
\end{tabular}

\footnotetext{
${ }^{1} \mathrm{O}$ processo de colmatação pode ser basicamente explicado como o entupimento do leito; caracteriza-se pela redução da condutividade hidráulica pelo material poroso, causada pela combinação do processo biológico de crescimento microbiano (biofilme) com a acumulação de material particulado presente no meio líquido (METCALF; EDDY, 2003).
} 


\subsection{Meio de cultura}

A base do meio nutricional dos reatores em batelada e reator contínuo de leito fluidificado foi aquela estabelecida por Torres (1992) e modificado por Duarte et al. (2006), conforme descrição nas Tabela 4.2 e Tabela 4.3.

Tabela 4.2 - Composição do meio de cultura.

\begin{tabular}{cc} 
Componente & q.s.p. 1000 mL \\
\hline Extrato de levedura (Kasvi, K25-611005) & $500 \mathrm{mg}$ \\
Etanol & $192,2 \pm 50,8 \mathrm{mg}$ \\
Bicarbonato de sódio & $400 \mathrm{mg}$ \\
Solução de sais (Tabela 4.3) & $5,0 \mathrm{ml}$ \\
\hline
\end{tabular}

q.s.p. - quantidade suficiente para

Fonte: modificado de Duarte (2006).

Tabela 4.3 - Composição da solução de sais para meio de cultura.

\begin{tabular}{cc}
\hline Sais & q.s.p. $\mathbf{1 0 0 0 ~} \mathbf{~ L L}$ \\
\hline $\mathrm{NaCl}$ & 50 \\
$\mathrm{MgCl}_{2} .6 \mathrm{H}_{2} \mathrm{O}$ & $1,4 \mathrm{~g}$ \\
$\mathrm{CaCl}_{2} \cdot 2 \mathrm{H}_{2} \mathrm{O}$ & $0,9 \mathrm{~g}$ \\
\hline
\end{tabular}

q.s.p. - quantidade suficiente para

Fonte: Torres (1992)

A solução de sais foi preparada quinzenalmente e mantida sob refrigeração em frasco âmbar de 1,0 L. Os demais compostos foram pesados semanalmente e mantidos em frascos tampados. Os componentes do meio de cultura foram dissolvidos em água da rede pública de abastecimento, completando o volume do frasco de alimentação.

A solução de 4-NF usada nos ensaios em reatores em batelada e na alimentação do RALF foi preparada em etanol e água ultrapura (50:50, v/v). Inicialmente o 4-NF foi adicionado em etanol p.a. e agitado homogeneizado até completa solubilização, seguido da adição de igual 
volume de água ultrapura. Este procedimento foi necessário devido as características hidrofóbicas do 4-NF.

\subsection{Ensaios em Reator em Batelada}

Nos ensaios em batelada foi estimado o potencial metanogênico com as diferentes concentrações de 4-NF. Este experimento foi realizado em reatores anaeróbios em batelada (frascos Duran ${ }^{\circledR}$ ) de $500 \mathrm{~mL}$ de volume total, sendo $250 \mathrm{~mL}$ de headspace e $250 \mathrm{~mL}$ de volume reacional, em triplicata. Os reatores foram alimentados com meio de cultura idêntico ao da alimentação do reator anaeróbio de leito fluidificado em escala aumentada (Tabela 4.2 e Tabela 4.3), juntamente com o co-substrato de cada ensaio.

A concentração de cada co-substrato utilizado foi padronizada de acordo com a concentração de etanol (200 mg L$\left.{ }^{-1}\right)$ propostas por Macedo et al. (2015), equivalente a 4,3 mM. Assim, o valor teórico de cada co-substrato adicionado foi de $200 \mathrm{mg} \mathrm{L}^{-1}$ de Etanol, $140 \mathrm{mg} \mathrm{L}^{-}$ ${ }^{1}$ de Metanol e 600 mg L $^{-1}$ de Fumarato (Sigma-Aldrich ${ }^{\circledR}$, CAS n ${ }^{\circ}$ 17013-01-3).

O inóculo dos reatores em batelada foi proveniente de reator UASB usado no tratamento de água residuária de abatedouro de aves (Pereira, São Paulo), o mesmo lodo utilizado para inoculação do RALF. O lodo antes de ser utilizado, passou por condicionamento em câmara termo estatizada a $30 \pm 1^{\circ} \mathrm{C}$ por 10 dias, a fim de exaurir as fontes de carbono disponíveis no inóculo. Após este período, $2 \mathrm{~g} \mathrm{STV} \mathrm{L}^{-1}$ de lodo foi adicionado a cada reator, juntamente com o meio de cultura, os co-substratos e 4-NP.

Os reatores controle, sem adição de 4-NF ao meio reacional, seguiram a mesma operação dos demais. Para a confecção do meio de cultura preparou-se 1 L de solução para cada condição (Etanol, Metanol e Fumarato) de acordo com a composição nutricional das Tabelas 4.1 e 4.2, juntamente com a adição do co-substrato.

Os reatores foram submetidos ao fluxo de $\mathrm{N}_{2}(100 \%)$ por 10 minutos a fim de garantir a anaerobiose do meio. Posteriormente estes foram vedados com tampa de butila e rosca plástica. Os reatores foram mantidos sob agitação de $180 \mathrm{rpm}$ a $30 \pm 1^{\circ} \mathrm{C}$. O monitoramento dos reatores anaeróbios em batelada foi realizado por meio de análises inicial e final da composição do biogás $\left(\mathrm{H}_{2}, \mathrm{CH}_{4}\right.$ e $\mathrm{CO}_{2}$ ), matéria orgânica (DQO), pH, alcalinidade e 4-NF (Figura 4.2). 
Figura 4.2 - Fluxograma experimental dos ensaios de potencial metanogênico.

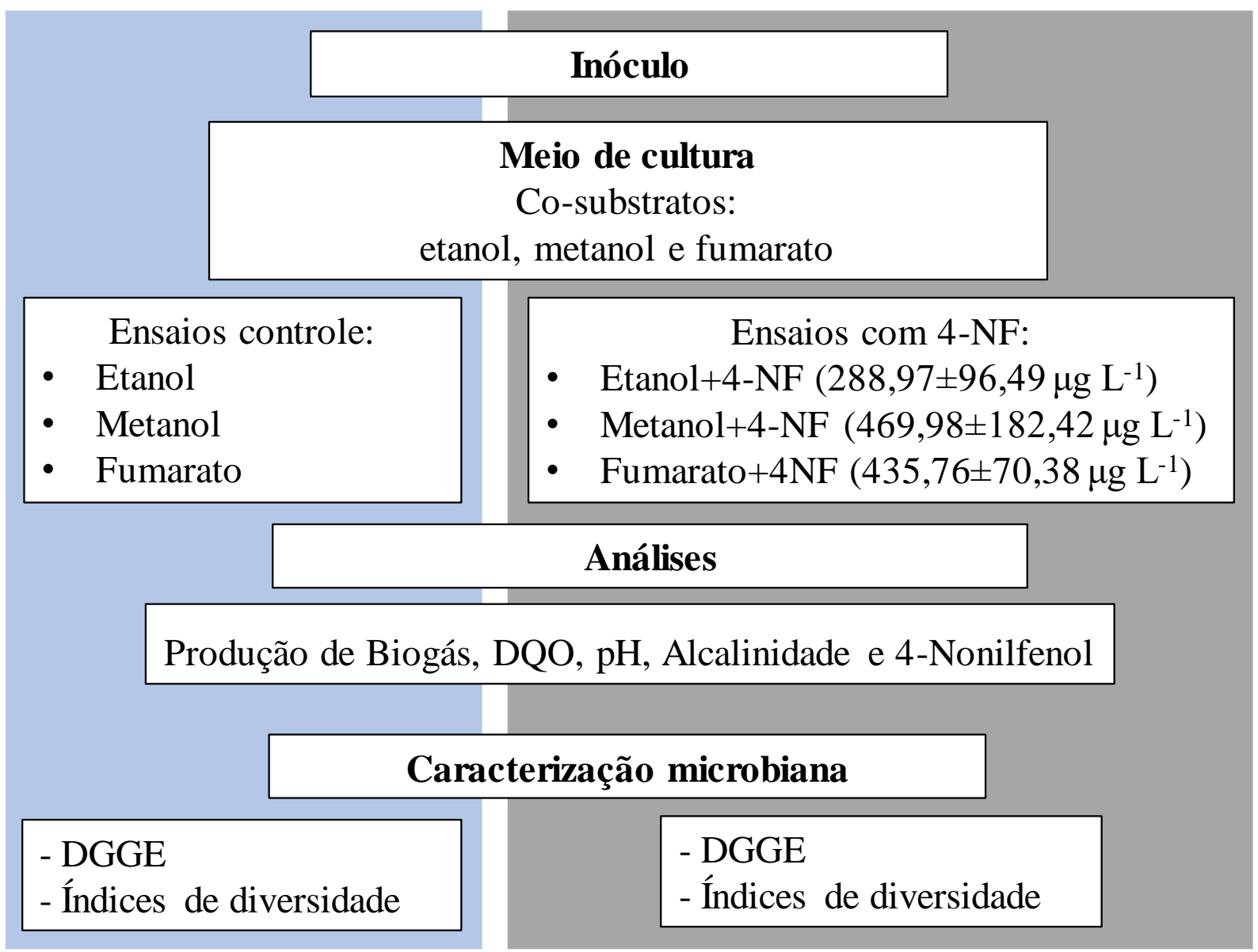

Fonte: $\mathrm{O}$ autor.

\subsection{Reator Anaeróbio de Leito Fluidificado}

O RALF foi construído em PVC (Policloreto de vinila) com $10 \mathrm{~cm}$ de diâmetro, $254 \mathrm{~cm}$ de altura, área de 78,54 $\mathrm{cm}^{2}$ com volume de $20 \mathrm{~L}$. Estas dimensões do reator foram as mesmas adotadas por Macedo (2015), em estudo da degradação de LAS em água residuária de lavanderia comercial $\mathrm{Na}$ base do reator foi instalado um distribuidor para garantir a uniformidade do fluxo e no topo, um separador de fases para impedir que partículas sólidas fossem levadas para o efluente. $\mathrm{O}$ esquema da configuração reacional pode ser visualizado na Figura 4.3. 
Figura 4.3 - Reator Anaeróbio de Leito Fluidificado em escala aumentada (RALF).

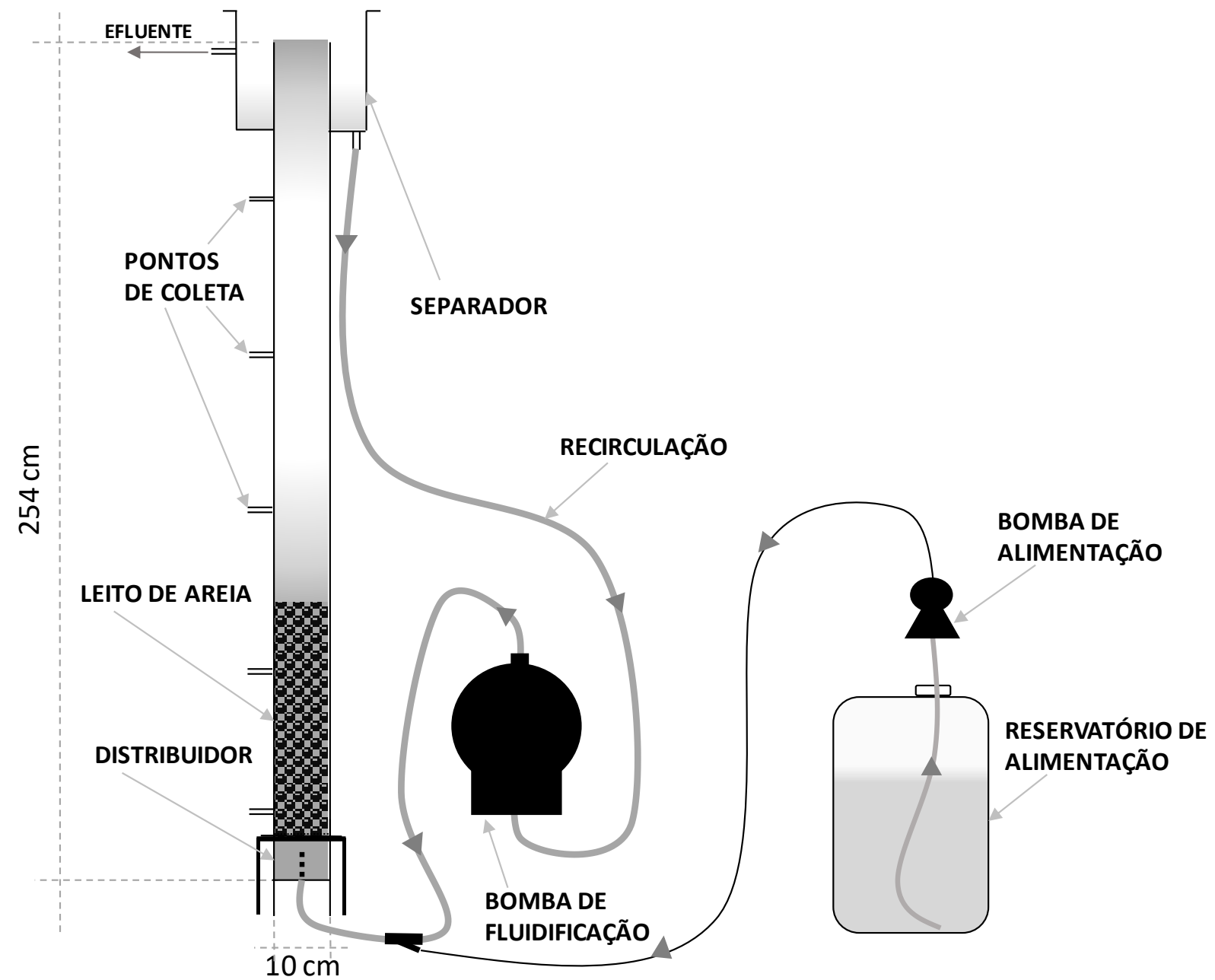

Fonte: $\mathrm{O}$ autor.

O reator foi instalado em sala anexa ao Laboratório de Processos Biológicos (LPB) e mantido em temperatura ambiente. A vazão da bomba de recirculação foi de $180 \mathrm{~L} \mathrm{~h}^{-1}$ e a vazão de alimentação de $1 \mathrm{~L} \mathrm{~h}^{-1}$, resultando em um TDH de 18,2 $\pm 1,1 \mathrm{~h}$. Estes parâmetros foram adotados devido aos bons resultados obtidos por Macedo et al. (2015).

Para a imobilização da biomassa no RALF utilizou-se areia como material suporte, devido aos bons resultados obtidos por Oliveira et al. (2010). As características físicas desse material suporte estão descritas na Tabela 4.4. 
Tabela 4.4 - Características da areia utilizada como material suporte.

\begin{tabular}{cccc} 
Material suporte & Massa $(\mathrm{g})$ & Diâmetro $(\mathrm{mm})$ & Densidade $\left(\mathrm{g} \mathrm{cm}^{-3}\right)$ \\
\hline Areia & 4500 & $0,8-1,2$ & 2,3 \\
\hline
\end{tabular}

Anterior a sua utilização no reator, a areia foi submetida a tratamento ácido com a finalidade de remover impurezas e criar rugosidades em sua superfície que facilitem a adesão da biomassa durante o período de inoculação do reator. Para isso a areia foi imersa em solução de ácido fluorídrico a 10\%, até completa limpeza. Após esse período a areia foi lavada em água corrente até completa retirada do ácido fluorídrico. Em seguida este material foi levado à estufa de secagem $\left(105^{\circ} \mathrm{C}\right)$ por 24 horas (SILVA, 1985).

Em relação a temperatura ambiente durante a operação do RALF foram usados os dados do Instituto Nacional de Meteorologia (INMET) da Estação Meteorológica Automática A711, da Embrapa Pecuária Sudeste, localizada em São Carlos - SP, com as coordenadas geográficas Latitude: $21^{\circ} 57^{\prime} 42^{\prime \prime}$, Longitude: 4750'28” e Altitude de $860 \mathrm{~m}$.

Para a imobilização da biomassa no material suporte (areia), o sistema foi mantido em circuito fechado com meio de cultura (Tabela 4.2 e Tabela 4.3) e $1 \mathrm{~L}$ de lodo (5\% do volume total do reator) por 7 dias. Conforme verificado o consumo de substrato (DQO), adicionou-se nova solução de meio de cultura (Tabela 4.2 e Tabela 4.3) ao frasco de alimentação do reator. Após a etapa de inoculação o sistema foi aberto (sistema contínuo), mantendo-se a mesma composição do meio de cultura (Tabela 4.2 e Tabela 4.3). O sistema foi operado com Tempo de Detenção Hidráulico (TDH) de 18,2ะ1,1 horas e a alimentação do reator mantida sob refrigeração a $4^{\circ} \mathrm{C}$.

Adição de alcalinizante (Bicarbonato de Sódio) foi realizada nas etapas de Inoculação e Adaptação, a fim de garantir o tamponamento do meio. Na etapa de adaptação a concentração de alcalinizante foi reduzida gradativamente até atingir zero. Da Fase I em diante não foi realizada a adição de alcalinizante a composição do meio de cultura (Tabela 4.2 e Tabela 4.3).

A operação do Reator Anaeróbio de Leito Fluidificado foi dividida em seis fases; iniciando-se com a inoculação do reator em circuito fechado (sem afluente e efluente de fluxo contínuo), adaptação da biomassa as condições nutricionais e reacionais e posteriores fases com adição de 4-NF. O fluxograma experimental das etapas de operação do RALF está ilustrado na Figura 4.4. 
Figura 4.4 - Fluxograma experimental das etapas de operação do RALF.

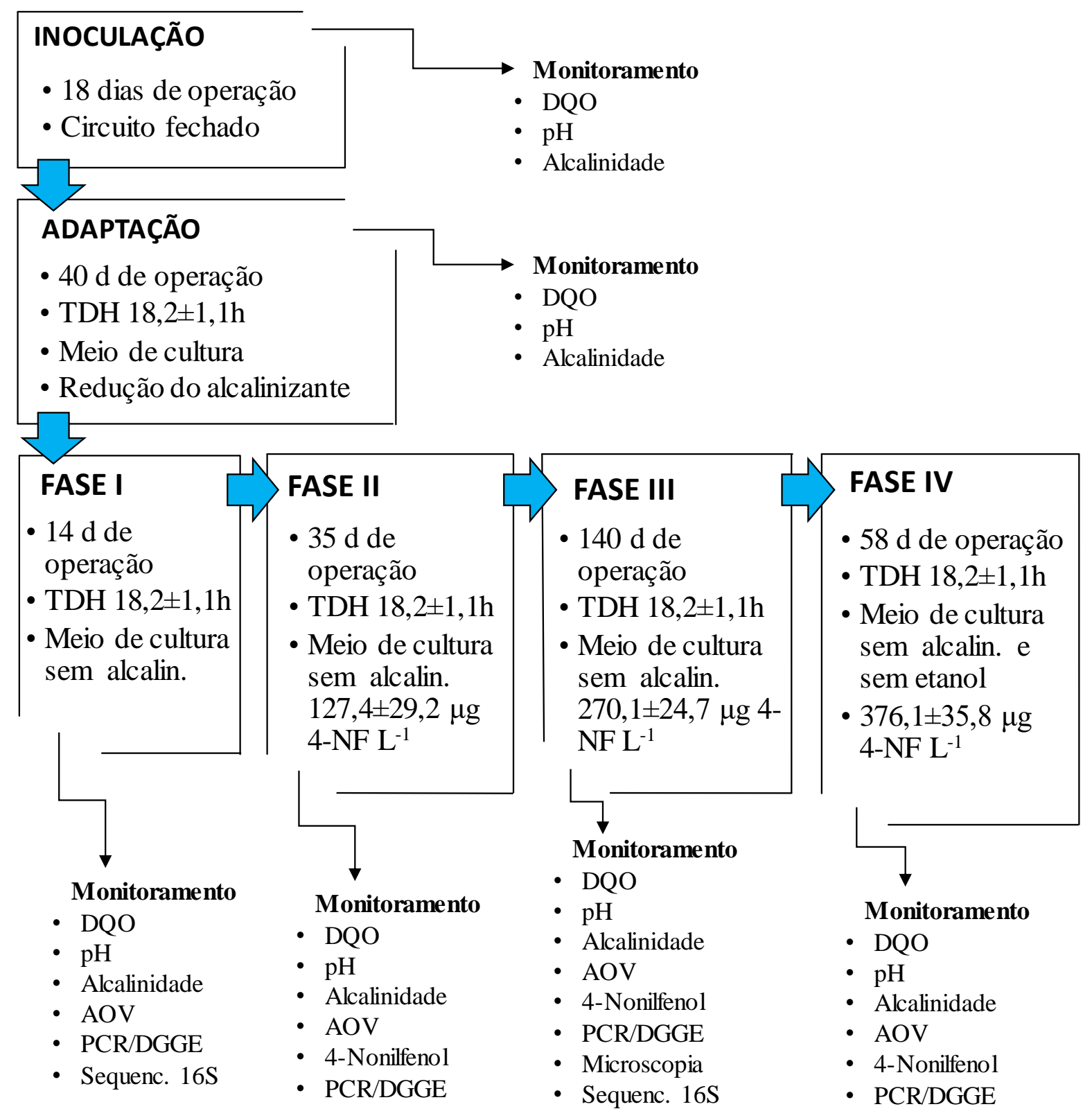

Fonte: $\mathrm{O}$ autor.

Após atingir remoção estável de DQO foram adicionadas diferentes concentrações de 4-Nonilfenol, seguindo as fases pré-estabelecidas. Estas fases foram denominadas II, III e IV e referem-se às concentrações de 4-NF de $127,4 \pm 29,2 ; 270,1 \pm 24,7$ e $376,1 \pm 35,8 \mu \mathrm{g} \mathrm{L}^{-1}$, respectivamente. Na Fase IV, além do aumento da concentração afluente de 4-NF, foi realizada redução da concentração de co-substrato (etanol) a composição nutricional do meio de cultura (Tabela 4.2 e Tabela 4.3). 


\subsection{Desenvolvimento de método analítico para quantificação de 4-NF}

A etapa inicial do projeto consistiu no desenvolvimento de método para quantificação do 4-Nonilfenol, baseado em condições de qualidade propostas pelo Método USEPA 8310 Polynuclear Aromatic Hydrocarbons, utilizando-se cromatografia líquida de alta eficiência com detector de fluorescência. Diferentes condições e métodos cromatográficos já foram relatados na literatura para a quantificação deste composto, sendo a Cromatografia Líquida de Alta Eficiência (HPLC) o mais adequado a rotina de laboratório para essa identificação e quantificação (LIU et al., 2003; CRUCERU et al., 2012).

Para tanto, foi desenvolvido o método cromatográfico de quantificação de NF no Laboratório de Processos Biológicos (LPB-EESC-USP), utilizando parâmetros já relatados em literatura a fim de balizar a confecção dessa ferramenta analítica (LIU et al., 2003; BARAHONA; TURIEL; MARTÍN-ESTEBAN, 2011; CRUCERU et al., 2012).

\subsubsection{Equipamento}

Foi usado um HPLC (Shimadzu ${ }^{\circledR}$ Co., Kyoto Japan), equipado com bomba LC10ADvp, válvula FCV-10 AL $\mathrm{AL}_{\mathrm{vp}}$, forno CTO-10A $\mathrm{A}_{\mathrm{vp}}$, detector de fluorescência RF10A $\mathrm{XL}$ e unidade controladora SCL-10A $\mathrm{A}_{\mathrm{vp}}$, para a determinação do 4-NF, utilizando o softwareClass-VP $\left(\right.$ Shimadzu $\left.^{\circledR}\right)$ para o controle do sistema operacional do HPLC. As condições cromatográficas avaliadas foram as seguintes: fase estacionária (colunas C-8 e C-18), fase móvel (solução acetonitrila/água em diferentes proporções), sistema de eluição isocrática, detector de fluorescência (diferentes comprimentos de onda - $\lambda$ ), temperatura e fluxo dos eluentes, conforme itens a seguir.

\subsubsection{Fase Estacionária}

Como fase estacionária foram usadas as colunas C-8 da Agilent ${ }^{\circledR}$ com tamanho de partícula de $5 \mu \mathrm{m}, 15 \mathrm{~cm}$ de comprimento e 4,6 mm de diâmetro interno e a coluna C-18 da Shimadzu ${ }^{\circledR}$ com tamanho de partícula de $5 \mu \mathrm{m}, 250 \mathrm{~mm}$ de comprimento e 4,6 mm de diâmetro. 


\subsubsection{Fase Móvel}

Como fase móvel foram usados Acetonitrila (J. T. Baker ${ }^{\circledR}$, CAS n ${ }^{\circ}$ 75-05-8) e água ultrapura (Merck Millipore ${ }^{\circledR}$ ). As proporções testadas de acetonitrila/água (v/v) foram de 90:10, $70: 10,50: 10$.

\subsubsection{Preparo da Solução Padrão e meio de cultura}

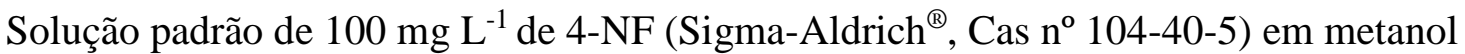
$\left(\right.$ Panreac $^{\circledR}, \mathrm{CAS} \mathrm{n}^{\circ}$ 67-56-1) foi preparada e armazenada a $2^{\circ} \mathrm{C}$ em frasco âmbar. Posteriores diluições foram feitas a partir da solução estoque para testes das condições de quantificação e curva analítica. Outra solução de trabalho de $1000 \mu \mathrm{g} \mathrm{L} \mathrm{L}^{-1}$ de 4-NF em metanol foi também usada para quantificação das melhores condições de quantificação via método cromatográfico.

$\mathrm{O}$ meio de cultura usado nos testes de quantificação de 4-NF foi confeccionado de acordo com a composição nutricional das Tabela 4.2 e Tabela 4.3, a mesma usada para alimentação do RALF e ensaios com reatores anaeróbios em batelada.

Para amostras provenientes dos reatores em batelada e RALF, com alto teor de sólidos, deve-se centrifugar em frascos de vidro a $2.500 \mathrm{rpm}$ por $10 \mathrm{~min}$ para posterior extração em cartuchos SPE e quantificação em HPLC.

\subsubsection{Otimização dos Parâmetros Cromatográficos}

Os testes em HPLC para o desenvolvimento do método analítico foram iniciados usando solução de $1000 \mu \mathrm{g} \mathrm{L}{ }^{-1}$ de 4-NF solubilizado em metanol, coluna C-8 como fase estacionária e acetonitrila/água como fase móvel na proporção 90:10 (v/v). Para o detector de fluorescência² usou-se os comprimentos de onda ( $\lambda$ ) de $220 \mathrm{~nm}$ (excitação ${ }^{3}$ ) e 315 nm (emissão), conforme já

\footnotetext{
${ }^{2}$ A fluorescência é a emissão de luz a partir de um estado excitado, no qual o elétron excitado não muda a orientação (LAKOWICZ, 2006).

${ }^{3}$ Compostos orgânicos aromáticos emitem fluorescência e partir disso podem ser medidos; os espectros de fluorescência geralmente são apresentados como espectro de emissão, gerando uma curva de intensidade versus comprimento de onda em nanômetros (LAKOWICZ, 2006).
} 
relatado por Liu et al. (2003) e Cruceru et al. (2012). Esta primeira tentativa teve por objetivo obter a detecção do composto de interesse em uma matriz simples, sem demais contaminantes.

A seletividade do método foi verificada por meio da aplicação da técnica de superposição de matriz ${ }^{4}$ (RIBANI et al., 2004). Foram confeccionadas duas soluções de meio de cultura, uma contendo 4-NF e outra sem adição do composto. Os parâmetros de detecção otimizados foram fluxo dos eluentes, temperatura, volume de injeção e comprimentos de onda do detector de fluorescência.

Os fluxos dos eluentes testados foram de 0,5, 0,8 e $1 \mathrm{~mL} \mathrm{~min}^{-1}$. A escolha do melhor fluxo foi de acordo com a definição do pico de detecção, quanto a área e altura do mesmo. Foram testadas as temperaturas da coluna de $35^{\circ} \mathrm{C}, 40^{\circ} \mathrm{C}$ e $45^{\circ} \mathrm{C}$ para todos os fluxos testados anteriormente. A melhor resposta para cada parâmetro testado foi fixada e usada para os próximos testes, conforme fluxograma da Figura 4.5.

Figura 4.5 - Sequência de testes para quantificação de 4-Nonilfenol.

\begin{tabular}{|c|c|c|c|}
\hline Fluxo & Temperatura & Vol. de injeçã & Detecção \\
\hline - Vol. Injeção: $10 \mu \mathrm{L}$ & • Vol.Injeção $10 \mu \mathrm{L}$ & - Fluxo: $0,8 \mathrm{~mL} \mathrm{~min}^{-1}$ & - Fluxo: $0,8 \mathrm{~mL} \mathrm{~min}^{-1}$ \\
\hline - Temp.: $40^{\circ} \mathrm{C}$ & - Fluxo: $0,8 \mathrm{~mL} \mathrm{~min}^{-1}$ & - Temperatura: $40^{\circ} \mathrm{C}$ & - Temperatura: $40^{\circ} \mathrm{C}$ \\
\hline - NF:1000 $\mu \mathrm{g} \mathrm{L}^{-1}$ & - NF:1000 $\mu \mathrm{g} \mathrm{L}^{-1}$ & - NF:1000 $\mu \mathrm{g} \mathrm{L}^{-1}$ & - Vol. de injeção: $100 \mu \mathrm{L}$ \\
\hline - Exc: $220 \mathrm{~nm}$ & - Exc: $220 \mathrm{~nm}$ & - Exc: $220 \mathrm{~nm}$ & - NF:1000 $\mu \mathrm{g} \mathrm{L}^{-1}$ \\
\hline - Emi: $315 \mathrm{~nm}$ & - Emi: $315 \mathrm{~nm}$ & - Emi: $315 \mathrm{~nm}$ & - Comprimentos de onda \\
\hline - Fluxos testados: & - Temp. testadas: & - Volumes de inj. testados: & \\
\hline $0,5,0,8$ e $1,0 \mathrm{~mL} \mathrm{~min}^{-1}$ & 35,40 e $45^{\circ} \mathrm{C}$ & 30,50 e $100 \mu \mathrm{L}$ & \\
\hline
\end{tabular}

Fonte: $\mathrm{O}$ autor.

Os volumes de injeção testados foram de $10 \mu \mathrm{L}$ a $100 \mu \mathrm{L}$. Neste teste foram usadas concentrações de $2 \mu \mathrm{g} \mathrm{L}^{-1}, 5 \mu \mathrm{g} \mathrm{L} \mathrm{L}^{-1}$ e $60 \mu \mathrm{g} \mathrm{L} \mathrm{L}^{-1}$ de 4-NF. O volume de injeção foi aumentado para que pudesse se obter a detecção de menores concentrações do composto de interesse, sem que saturasse a capacidade de detecção. No detector de fluorescência RF10Axl foram testados

\footnotetext{
${ }^{4} \mathrm{O}$ método de superposição de matriz ("matrix-matched”) consiste na adição do padrão da substância de interesse em uma matriz similar à da amostra, isenta da substância, e construção do gráfico de calibração relacionando as áreas obtidas com as concentrações dos padrões. Este método é usado para compensar o efeito da matriz ou de possíveis interferentes e é de grande importância em determinações quando a matriz pode interferir na concentração, extração, separação ou detecção da substância de interesse (RIBANI et al., 2004).
} 
diferentes comprimentos de excitação e emissão já descritos na literatura, de acordo com a Tabela 4.5.

Tabela 4.5 - Comprimentos de onda de excitação e emissão testados.

\begin{tabular}{lcc}
\multicolumn{1}{c}{ Referência } & Excitação (nm) & Emissão (nm) \\
\hline $\begin{array}{l}\text { (CRUCERU et al., 2012) } \\
\text { (LIU et al., 2003) }\end{array}$ & 220 & 315 \\
(BARAHONA; TURIEL; MARTÍN-ESTEBAN, & 226 & 305 \\
2011) & 230 & 320 \\
(CHERNIAEV; KONDAKOVA; ZYK, 2016) & 230 & 300 \\
(BENNIE et al., 1997) & 225 & 305 \\
Neste estudo * & 225 & 315 \\
Neste estudo * & 220 & 305 \\
Neste estudo * & 25 & \\
\hline
\end{tabular}

*não relatados na literatura.

\subsubsection{Validação do método}

Após estabelecidas as condições otimizadas para a quantificação de 4-Nonilfenol, iniciou-se as etapas experimentais de ensaios em reator anaeróbio em batelada, pré-definidas de acordo com a concentração de surfactante 4-NF adicionada ao meio de cultura. Os ensaios em batelada foram usados para avaliar a remoção de 4-NF na presença de diferentes cosusbtratos (etanol, metanol e fumarato). Amostras desses reatores foram coletadas e usadas para análise da remoção em função do tempo, comprovando a aplicabilidade e robustez do método de quantificação desse surfactante por HPLC em uma matriz complexa.

A curva de quantificação de 4-NF foi realizada em meio de cultura, conforme Tabelas 4.1 e 4.2. Os parâmetros de qualidade para avaliar o método desenvolvido foram Seletividade, Linearidade, Limite de Deteç̧ão (LD), Limite de Quantificação (LQ), Exatidão, Precisão, Repetibilidade (RIBANI et al., 2004). 


\subsubsection{Seletividade}

A avaliação da seletividade do método desenvolvido foi realizada por meio da injeção de amostras contendo 4-NF e amostra isenta do analito. A seletividade também foi avaliada pelo método de sobreposição de matriz, usando meio de cultura (Tabela 4.2 e Tabela 4.3), efluente do RALF após adição de 4-NF ao meio de cultura, amostras de esgoto doméstico e água residuária de lavanderia.

\subsubsection{Linearidade}

A linearidade foi avaliada por meio de curvas analíticas obtidas pela proporção matemática entre o sinal analítico (áreas do cromatograma) e a concentração teórica (nominal) foi usada para a curva analítica.

\subsubsection{Precisão}

A precisão foi avaliada pelo desvio padrão relativo (RSD\%) (RIBANI et al., 2004), para concentrações entre 55,6 $\mu \mathrm{g} / \mathrm{L}$ e $3250 \mu \mathrm{g} / \mathrm{L}$ de $4-\mathrm{NF}$.

\subsubsection{Limite de Detecção}

O limite de detecção foi calculado com base nos parâmetros da curva analítica, conforme descrito por Ribani et al. (2004), de acordo com a equação 01.

$$
L D=3,3 * \frac{s}{s}
$$

Sendo:

LD = Limite de Detecção

$\mathrm{s}=$ coeficiente linear da equação;

$\mathrm{S}=$ Coeficiente angular da equação da curva analítica 


\subsubsection{Limite de Quantificação}

O limite de quantificação também foi obtido com base nos parâmetros da curva analítica, conforme descrito por Ribani et al. (2004), por ser estatisticamente mais confiável; de acordo com a equação 02 .

$$
L D=10 * \frac{s}{S}
$$

Sendo:

LD = Limite de Detecção

$\mathrm{s}=$ coeficiente linear da equação;

$\mathrm{S}=$ Coeficiente angular da equação da curva analítica

\subsubsection{Preparo de amostras}

O método de Extração em Fase Sólida (Solid Phase Extraction - SPE) foi usado para purificação e concentração de amostras. Os cartuchos foram acoplados a estação de filtração a vácuo (Vacuum Manifold Processing Station, Agilent Technologies ${ }^{\circledR}$ ) e submetidos a filtração com bomba de vácuo (Prismatec ${ }^{\circledR}$ ) a pressão de 5 bar. Os Cartuchos testados para extração em fase sólida estão descritos na Tabela 4.6.

Tabela 4.6 - Cartuchos testados para extração em fase sólida (SPE).

\begin{tabular}{cccl}
\hline Cartucho & Marca & Tamanho & \multicolumn{1}{c}{ Composição } \\
\hline C18-ODS & Agilent Technologies $^{\circledR}$ & $6 \mathrm{~mL}$ & Sílica modificada-octadecil (500 mg) \\
C18-ec & Macherey-Nagel $^{\circledR}$ & $6 \mathrm{~mL}$ & Sílica modificada-octadecil (500 mg) \\
Alumina & Supelco $^{\circledR}$ & $6 \mathrm{~mL}$ & Óxido de alumínio (2g) \\
\hline
\end{tabular}

Anteriormente a adoção de cartuchos SPE como método de purificação de amostras, testou-se filtração a vácuo com membranas como tentativa de reduzir os procedimentos de análise de cada amostra, bem como o custo do método. Foram testados três tipos de membranas com porosidade de 0,2 $\mu \mathrm{m}$, sendo: membrana de Acetato de Celulose (StarTech ${ }^{\circledR}$ ), Celulose Regenerada (Sartorius ${ }^{\circledR}$ ) e Fibra de Vidro $\left(\operatorname{StarTech}^{\circledR}\right)$. Solução em meio de cultura (Tabela 4.2 e Tabela 4.3 ) com $2.999,27 \pm 74,95 \mu \mathrm{g} 4-\mathrm{NF} \mathrm{L}^{-1}$ foi filtrada em quintuplicada para cada 
membrana testada. As concentrações médias verificadas após a filtração foram comparadas estatisticamente com a concentração da solução controle pelo teste de Tukey a $5 \%$ de probabilidade de erro.

Os procedimentos de filtração em membranas, cartuchos SPE e manuseio de eluentes foram executados em capela de exaustão (Quimis ${ }^{\circledR}$ ) devido ao alto teor de solventes (etanol, metanol e acetonitrila) utilizados.

\subsection{Análises Físico-químicas}

As amostras do afluente e efluente do RALF e aquelas do reator em batelada foram analisadas seguindo a frequência e parâmetros apresentados na Tabela 4.7.

Tabela 4.7 - Análises de monitoramento do RALF e reator em batelada

\begin{tabular}{lccc}
\hline \multicolumn{1}{c}{ Parâmetros } & Método & Frequência & Referências \\
\hline $\mathrm{pH}$ & Potenciométrico & 2X semana & APHA (2005) \\
Alcalinidade & Titulométrico & 2X semana & RIPLEY et al. (1986) \\
DQO & Espectrofotométrico & 2X semana & APHA (2005) \\
Sólidos (STV) & Gravimétrico & - & APHA (2005) \\
4-Nonilfenol & HPLC & 2X semana & $*$ \\
Ácidos orgânicos voláteis & HPLC & 1X semana & PENTEADO (2012) \\
Vazão $\left(\mathrm{mL} \mathrm{h}^{-1}\right)$ & Volumétrico & 1X semana & - \\
Biogás & GC & - & PERNA et al. $(2013)$
\end{tabular}

*Desenvolvido no presente trabalho. DQO - Demanda química de oxigênio, HPLC - Cromatografia liquida de alta eficiência; $\mathrm{CG}$ - Cromatografia gasosa

A análise da composição de biogás foi realizada em cromatógrafo gasoso modelo GC 2010 (Shimadzu $^{\circledR}$, Scientific Instruments ${ }^{\circledR}$, Columbia, MD, EUA), equipado com detector de condutividade térmica (TCD), com coluna Supelco Carboxen ${ }^{\circledR} 1010$ Plot (30 m x 0,53 mm de diâmetro externo, $0,30 \mu \mathrm{m}$ de espessura), utilizando argônio como gás de arraste $\left(5,66 \mathrm{~mL} \mathrm{~min}^{-}\right.$ ${ }^{1}$ ). As temperaturas do injetor e do detector foram de $220^{\circ} \mathrm{C} \mathrm{e} 230^{\circ} \mathrm{C}$, respectivamente. A rampa 
de aquecimento da coluna foi de 130 a $135^{\circ} \mathrm{C}$, a $46^{\circ} \mathrm{C}^{-1}$, com tempo de corrida aproximado de 6 min. A amostra do headspace $(0,5 \mathrm{~mL})$ foi coletada dos reatores pressurizados com auxílio de uma seringa gastight com trava e imediatamente analisada.

\subsubsection{Extração de 4-Nonilfenol Adsorvido e Balanço de Massa}

A quantificação de 4-Nonilfenol adsorvido na biomassa do RALF foi baseada em método descrito por Duarte et al. (2008). Ao final da operação do RALF, foram retiradas amostras de biomassa do leito de areia para determinação do 4-Nonilfenol adsorvido e cálculo do balanço de massa. Essas amostras foram transferidas para estufa a $65^{\circ} \mathrm{C}$ por 24 horas para posterior realização da extração.

A amostra seca foi pesada e imersa e submetidas ao banho em metanol por três vezes (10 mL) sob ultrassom por $30 \mathrm{~min}$, seguida de dois banhos em água ultrapura $(10 \mathrm{~mL}) \mathrm{e}$ ultrassom (30 min). Após cada banho, a fase líquida foi coletada e transferida para balão volumétrico completando o volume para $50 \mathrm{~mL}$ e posterior centrifugação em frasco de vidro a $2500 \mathrm{rpm}$.

\subsubsection{Exames Microscópicos}

Análises de microscopia eletrônica de varredura (MEV) foram realizadas durante as fases de operação do reator para verificar a formação do biofilme microbiano, por meio do Digital Scanning Microscope da Zeiss ${ }^{\circledR}$ modelo DSM-960. As amostras foram preparadas de acordo com método descrito por Nation (1983) e modificado por Araújo (1994).

\subsubsection{Caracterização Microbiana}

A comunidade microbiana dos reatores em batelada e RALF foram comparadas por meio do perfil de bandas do DGGE (Eletroforese em Gel de Gradiente Desnaturante), com a construção de matrizes usando o software BioNumerics ${ }^{\circledR}$ versão 7.0 (Applied Maths ${ }^{\circledR}$, SintMartens-Latem, Bélgica). Os valores gerados foram usados para cálculos de coeficiente de similaridade. O agrupamento do dendograma foi realizado usando algoritmo UPGMA (Unweighted Pair Group Method with Arithmetic Averages) e o coeficiente de similaridade 
utilizado foi o coeficiente de Pearson. Os índices ecológicos foram calculados usando o software Past.

O DNA foi extraído usando o kit PowerSoil ${ }^{\circledR}$ DNA Isolation (MoBio Laboratories, Inc., Carlsbad, CA, EUA) de acordo com as instruções do fabricante. A qualidade do DNA e as concentrações foram avaliadas por eletroforese em gel (agarose a 1\%) e espectrofotômetro ND2000 (Nanodrop Inc., Wilmington, DE), usando uma razão de 260/280 nm > 1,8. Na PCR foram usados iniciadores set primer 968FGC - 1401R, para o Domínio Bacteria (NUBEL et al., 1996).

As condições da eletroforese do DGGE foram de $75 \mathrm{~V}$ a $60^{\circ} \mathrm{C}$ por 16 horas. Após esse período, o gel foi corado com Brometo de Etídeo. A leitura do perfil padrão das bandas do DGGE foi realizada no Sistema de Fotodocumentação (L.PixTouch - Loccus Biotechnology) sob a exposição UV de $254 \mathrm{~nm}$.

Para análise filogenética das amostras referentes ao RALF (Inóculo, Fase I, Fase III e Grânulos), as amostras de DNA foram enviadas para GenOne Soluções em Biotecnologia (www.genone.com.br, RJ, Brasil). Na PCR foi usado o set de primers 515F/907R (Domínio Bacteria) do gene RNAr 16S, região variável V4-V5. O sequenciamento foi realizado via plataforma Illumina - MiSeq seguindo as diretrizes do fabricante. Os dados foram avaliados na GenOne, com bioinformática primária para metabarcoding (unindo pares, removendo adaptadores, removendo reads que não contém primers e removendo os primers, filtrando por qualidade, criando OTU, tabelas com contagem de OTU, classificação taxonômica das OTU, diversidade alfa e curva de rarefação.

\subsubsection{Tratamento estatístico dos dados experimentais}

Os dados experimentais dos reatores em batelada e RALF foram submetidos a análise de variância (ANOVA) e a comparação entre as médias foi realizada usando o teste de Tukey ${ }^{5}$ a $5 \%$ de probabilidade de erro ( $p$-valor: 0,05$)^{6}$.

\footnotetext{
${ }^{5} \mathrm{O}$ Teste de Tukey consiste na comparação de todos os possíveis pares de médias e se baseia na diferença mínima significativa. Para grupos amostrais de mesmo tamanho, o Teste de Tukey é um teste exato, ou seja, para o conjunto de todas as comparações par a par, a taxa de erro do conjunto dos testes é exatamente $\alpha$ (nível de significância) e o intervalo de confiança é também exatamente $1-\alpha$ (TUKEY, 1949).

${ }^{6} \mathrm{O}$ valor de significância é valor de variação máximo aceito para que um par seja considerado estatisticamente igual.
} 
Os valores de produção de biogás verificados no reatores anaeróbios em batelada, foram ajustados pela equação de Gompertz ${ }^{7}$ modificada (Equação 1) (ZWIETERING et al., 1990; PEIXOTO et al., 2012), sendo possível determinar o potencial de produção de metano, produção acumulada de metano, taxa de produção de metano e período de início da produção de metano.

$$
\mathrm{M}=\mathrm{P} \exp \left\{-\exp \left[\frac{\mathrm{Rm} \cdot e}{\mathrm{P}}(\lambda-\mathrm{t})+1\right]\right\}
$$

Sendo:

$\mathrm{M}=$ produção acumulada de metano $(\mu \mathrm{mol})$,

$\mathrm{P}=$ produção potencial de metano $(\mu \mathrm{mol})$

$\mathrm{Rm}=$ taxa de produção de metano $\left(\mu \mathrm{mol} \mathrm{h}^{-1}\right)$

$\lambda=$ período de início da produção de metano (horas)

$\mathrm{t}=$ tempo (horas)

e $=$ número de Euler $(2,71828)$

Os parâmetros $\mathrm{P}, \mathrm{Rm}$ e $\lambda$ foram calculados com o software OriginPro ${ }^{\circledR} 8.1$ (OriginLab Corporation $^{\odot}$ ) e foram realizadas acima de 100 interações para convergir os dados usando o modelo matemático supracitado.

\footnotetext{
${ }^{7}$ A equação de Gompertz é um modelo aplicado em biologia que utiliza uma função sigmoidal para descrever uma serie de dados de uma variável sob um intervalo de tempo definido, deste modo, pode ser aplicada para predizer o crescimento microbiano de uma comunidade de organismos (ZWIETERING et al., 1990)
} 


\section{RESULTADOS E DISCUSSÃO}

Neste item serão apresentados os resultados deste estudo, iniciando com o desenvolvimento de método de quantificação de 4-NF, testes de co-substratos em reatores anaeróbios em batelada e operação e monitoramento do Reator Anaeróbio de Leito Fluidificado para a remoção e degradação do 4-NF.

\subsection{Desenvolvimento do método de quantificação o de 4-Nonilfenol}

Os testes em HPLC foram realizados preliminarmente com a solução de 4-NF de 1000 $\mu \mathrm{g} \mathrm{L} \mathrm{L}^{-1}$ em metanol, acetonitrila/água na proporção de 90:10 (v/v) como fase móvel, temperaturas do forno em $35^{\circ} \mathrm{C}, 40^{\circ} \mathrm{C}$ e $45^{\circ} \mathrm{C}$, fluxos de eluição de $0,5 \mathrm{~mL} \mathrm{~min}^{-1}, 0,8 \mathrm{~mL} \mathrm{~min}^{-}$ ${ }^{1}$ e $1,0 \mathrm{~mL} \mathrm{~min}^{-1}$, colunas C-8 $\left(\right.$ Agilent $\left.^{\circledR}\right)$ e C-18 (Shimadzu $\left.{ }^{\circledR}\right)$ como fase estacionária. No detector de fluorescência usou-se os comprimentos de onda de $220 \mathrm{~nm}\left(\lambda_{\text {exc }}\right)$ e $315 \mathrm{~nm}\left(\lambda_{\text {em }}\right)$, conforme descrito por Liu et al. (2003) e Cruceru et al. (2012).

Neste primeiro resultado foi possível identificar e detectar o composto de interesse e verificar qual a melhor coluna cromatográfica de separação analítica para o 4-NF. Em ambas as colunas cromatográficas testadas (C-8 e C-18) foi possível obter a seletividade para o analito, indicada pela boa separação dos picos cromatográficos referente ao analito bem como os picos referentes a composição do meio de cultura. As áreas cromatográficas referentes aos testes nas colunas C-8 e C18, com diferentes temperaturas $\left(35^{\circ} \mathrm{C}, 40^{\circ} \mathrm{C}\right.$ e $\left.45^{\circ} \mathrm{C}\right)$ e fluxos de eluição $(0,5$ $\mathrm{mL} \min ^{-1}, 0,8 \mathrm{~mL} \mathrm{~min}{ }^{-1}$ e $1,0 \mathrm{~mL} \mathrm{~min}^{-1}$ ), podem ser verificados na Tabela 5.1. 
Tabela 5.1- Teste de detecção de 4-NF com variação de fase estacionária utilizando colunas cromatográficas C-8 $\left(\right.$ Agilent $\left.^{\circledR}\right)$ e C-18 $\left(\right.$ Shimadzu $\left.^{\circledR}\right)$, para as temperaturas de $35^{\circ} \mathrm{C}, 40^{\circ} \mathrm{C}$ e $45^{\circ} \mathrm{C}$, fluxos de eluição de $0,5 \mathrm{~mL} \mathrm{~min}^{-1}, 0,8 \mathrm{~mL} \mathrm{~min}^{-1}$ e $1,0 \mathrm{~mL} \mathrm{~min}^{-1}$ e acetonitrila/água nas proporções 90:10 (v/v) como fase móvel.

\begin{tabular}{|c|c|c|c|c|c|}
\hline Coluna & $\begin{array}{c}\text { Temperatura } \\
\left({ }^{\circ} \mathrm{C}\right)\end{array}$ & $\begin{array}{c}\text { Fluxo } \\
\left(\mathrm{mL} \min ^{-1}\right)\end{array}$ & 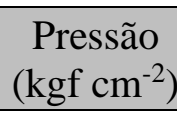 & $\begin{array}{c}\text { Tempo de } \\
\text { retenção (min) }\end{array}$ & Área \\
\hline \multirow{9}{*}{$\begin{array}{c}\text { C-8 } \\
\left(\text { Agilent }^{\circledR}\right)\end{array}$} & \multirow{3}{*}{35} & 1 & 22 & 3,02 & 3.197 .929 \\
\hline & & 0,8 & 18 & 3,79 & 4.009 .194 \\
\hline & & 0,5 & 11 & 6,07 & 6.522 .803 \\
\hline & \multirow{3}{*}{40} & 1 & 21 & 2,88 & 3.172 .647 \\
\hline & & 0,8 & 17 & 3,58 & 4.115 .893 \\
\hline & & 0,5 & 11 & 5,73 & 6.475 .660 \\
\hline & \multirow{3}{*}{45} & 1 & 20 & 2,77 & 3.199 .221 \\
\hline & & 0,8 & 16 & 3,46 & 4.038 .492 \\
\hline & & 0,5 & 10 & 5,54 & 6.450 .971 \\
\hline \multirow{9}{*}{$\begin{array}{c}\mathrm{C}-18 \\
\left(\mathrm{Shimadzu}^{\circledR}\right)\end{array}$} & \multirow{3}{*}{35} & 1 & 56 & 5,96 & 3.984 .745 \\
\hline & & 0,8 & 47 & 7,55 & 5.013 .762 \\
\hline & & 0,5 & 29 & 12,071 & 7.846 .737 \\
\hline & \multirow{3}{*}{40} & 1 & 53 & 5,68 & 3.934 .145 \\
\hline & & 0,8 & 42 & 7,21 & 4.919 .265 \\
\hline & & 0,5 & 32 & 11,22 & 8.319 .225 \\
\hline & \multirow{3}{*}{45} & 1 & 58 & 5,37 & 4.080 .279 \\
\hline & & 0,8 & 46 & 6,69 & 5.115 .348 \\
\hline & & 0,5 & 30 & 10,67 & 8.191 .792 \\
\hline
\end{tabular}

Para a coluna analitica C-18 foram verificadas as maiores áreas cromatográficas em comparação as condições testadas com a coluna C-8, entretanto, os cromatogramas apresentaram menor simetria e a maior área foi gerada pela maior largura dos picos cromatográficos (Tabela 5.1). Além disso, com a coluna C-8 foi possível obter menores tempos de retenção do analito, proporcionando corridas cromatográficas mais curtas e com boa separação analítica. Devido a estes fatores, optou-se pela coluna cromatográfica C-8 para os demais testes de detecção do 4-NF. A comparação entre cromatogramas de 4-NF em colunas C-8 e C-18 pode ser verificada na Figura 5.1. 
Figura 5.1 - Cromatogramas de 4-Nonilfenol em coluna cromatográfica C-8 (Agilent ${ }^{\circledR}$ ) e C-18 $\left(\right.$ Shimadzu $\left.{ }^{\circledR}\right)$, com temperatura de $40^{\circ} \mathrm{C}$, fluxos de eluição de $0,8 \mathrm{~mL} \mathrm{~min}^{-1}$ e acetonitrila/água na proporção 90:10 (v/v) como fase móvel.

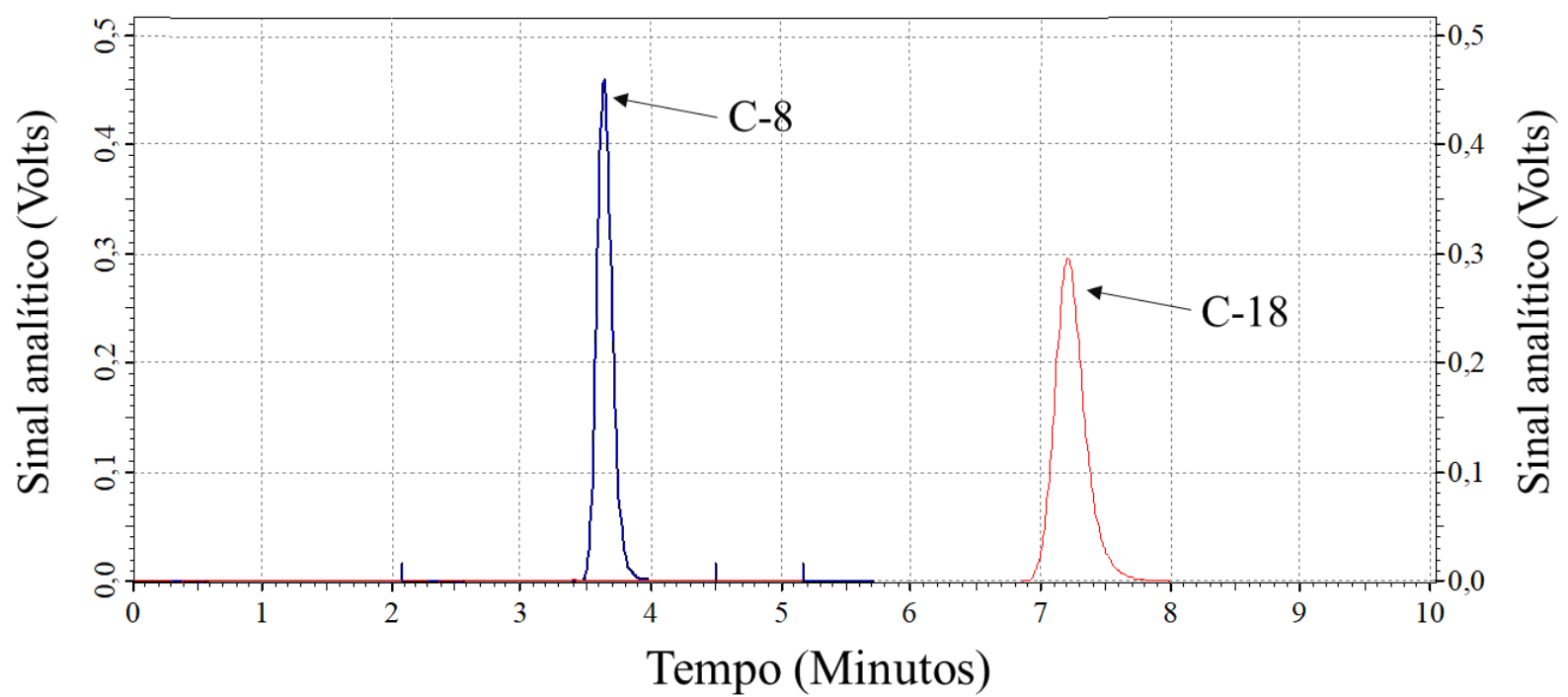

Fonte: $\mathrm{O}$ autor.

Para a coluna C-8, o aumento do fluxo dos eluentes gerou aumento da pressão na coluna, para todos os valores testados. Entretanto, o aumento da temperatura provocou a redução da pressão em todos os fluxos. Isto pode estar relacionado a redução da viscosidade do eluentes (acetonitrila/água) proporcionada pelo aumento da temperatura, causando, consequentemente, redução da pressão na coluna. Segundo Lanças (2012) a temperatura do método cromatográfico tem influência direta tanto no carreamento do analito quanto na pressão exercida no sistema, possibilitando assim a utilização de fluxos maiores porem sob pressões menores, entretanto isso pode afetar a interação do analito com a fase estacionária.

A redução do fluxo de eluição alterou a altura e largura do pico cromatográfico. O menor fluxo testado $\left(0,5 \mathrm{~mL} \mathrm{~min}^{-1}\right)$ proporcionou maiores áreas cromatográficas em comparação aos demais fluxos $\left(0,8 \mathrm{~mL} \mathrm{~min}^{-1} \mathrm{e} 1,0 \mathrm{~mL} \mathrm{~min}{ }^{-1}\right)$, para todas as temperaturas testadas $\left(35^{\circ} \mathrm{C}, 40^{\circ} \mathrm{C}\right.$ e $45^{\circ} \mathrm{C}$ ). Dessa forma os fluxos de $0,8 \mathrm{~mL} \mathrm{~min}^{-1}$ e $1,0 \mathrm{~mL} \mathrm{~min}^{-1} \mathrm{sob}$ as temperaturas de $35^{\circ} \mathrm{C}$, $40^{\circ} \mathrm{C}$ e $45^{\circ} \mathrm{C}$ proporcionou o estreitamento da base do pico e aumento da altura do pico

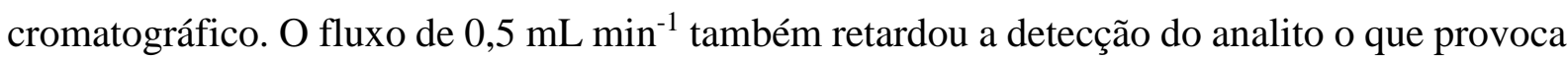
aumento do tempo de corrida cromatográfica, uma vez que seria necessário um maior tempo para a estabilidade do sistema para a nova injeção. A largura do pico cromatográfico deve ser a menor possível para garantir que outros compostos não coincidam no mesmo tempo retenção do início ou final da base, comprometendo a seletividade do método de separação e a 
conformidade do sistema de detecção (RIBANI et al., 2004). O pico cromatográfico com a melhor seletividade e maior área cromatográfica foi verificado para a condição com fluxo de eluição de $0,8 \mathrm{~mL} \mathrm{~min}{ }^{-1}$ e temperatura de $40{ }^{\circ} \mathrm{C}$, como indicam os cromatogramas da Figura 5.2 .

Figura 5.2 - Cromatogramas de 4-Nonilfenol em coluna cromatográfica C-8 (Agilent ${ }^{\circledR}$ ) com temperatura $40^{\circ} \mathrm{C}$, fluxos de eluição de $0,5 \mathrm{~mL} \mathrm{~min}^{-1}, 0,8 \mathrm{~mL} \min ^{-1}$ e $1,0 \mathrm{~mL} \mathrm{~min}{ }^{-1}$ e acetonitrila/água na proporção 90:10 (v/v) como fase móvel.

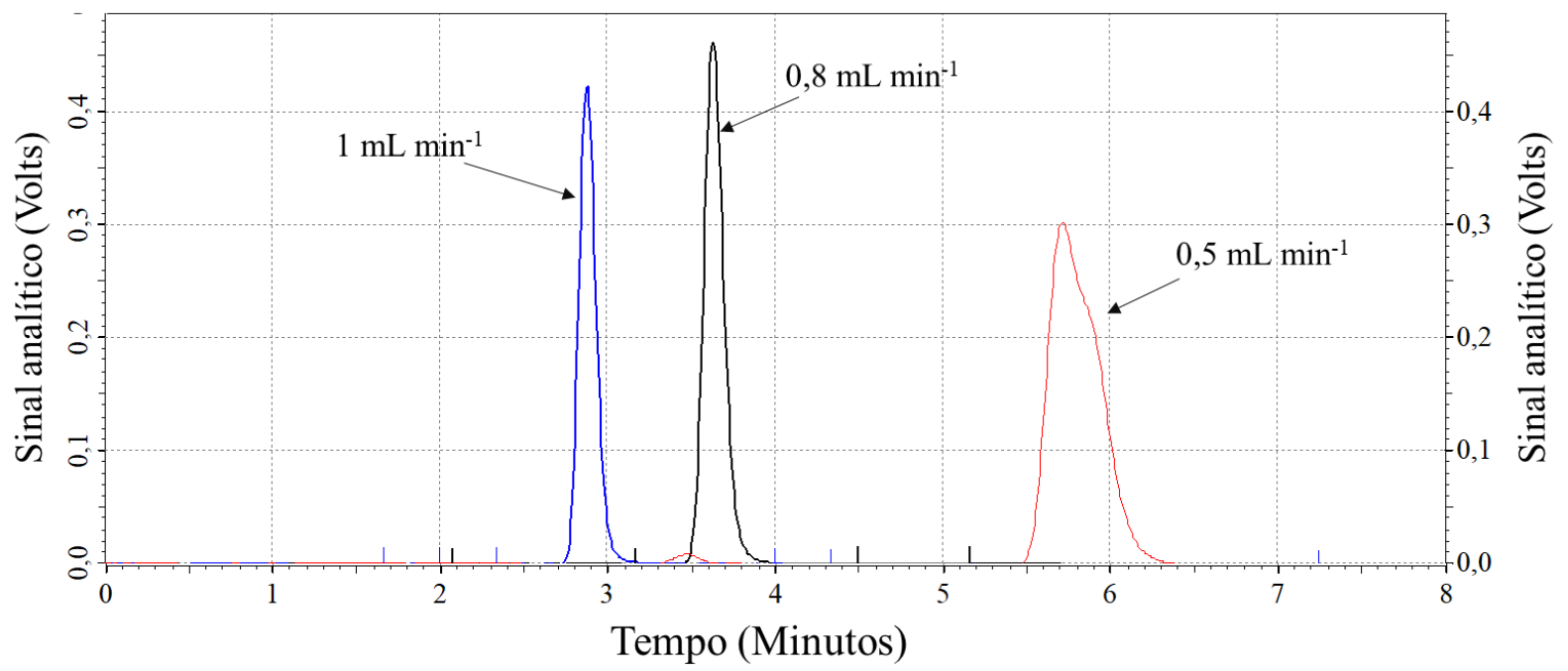

Fonte: $\mathrm{O}$ autor.

Para avaliar os efeitos dos fluxos de eluição na detecção do 4-NF, os demais parâmetros foram fixados para garantir que a resposta obtida fosse unicamente devido a variação do fluxo. $\mathrm{O}$ volume de injeção foi fixado em $10 \mu \mathrm{L}$, temperatura de $40^{\circ} \mathrm{C}$, e comprimento de onda foi fixado em $220 \mathrm{~nm}\left(\lambda_{\text {exc }}\right)$ e $315 \mathrm{~nm}\left(\lambda_{\text {em }}\right)$. Foram realizadas injeções com fluxos de 0,5 mL min ${ }^{-}$ 1, 0,8 $\mathrm{mL} \mathrm{min}^{-1}$ e 1,0 $\mathrm{mL} \mathrm{min}^{-1} \mathrm{e}$ as áreas cromatográficas obtidas foram comparadas entre si. Após a identificação do melhor fluxo de eluição para detecção do analito, este foi fixado e os demais parâmetros variados.

A alteração da temperatura do forno provocou variação no pico cromatográfico do 4$\mathrm{NF}$ para todos os fluxos testados. Com relação ao fluxo de eluição de $0,8 \mathrm{~mL} \mathrm{~min}{ }^{-1}$, as áreas cromatográficas foram de 4.009.194, 4.115.893 e 4.038.492, para as temperaturas de $35^{\circ} \mathrm{C}$, $40^{\circ} \mathrm{C}$ e $45^{\circ} \mathrm{C}$, respectivamente. A Figura 5.3 ilustra a comparação entre os picos cromatográficos obtidos para as diferentes temperaturas testadas, com fluxo de eluição de 0,8 $\mathrm{mL} \min ^{-1}$. 
Figura 5.3 - Cromatograma de 4-Nonilfenol em coluna C-8 (Agilent ${ }^{\circledR}$ ) com fluxo de eluição de $0,8 \mathrm{~mL} \mathrm{~min}^{-1}$, para temperaturas de $35^{\circ} \mathrm{C}, 40^{\circ} \mathrm{C}$ e $45^{\circ} \mathrm{C}$ e acetonitrila/água na proporção de 90:10 (v/v) como fase móvel.

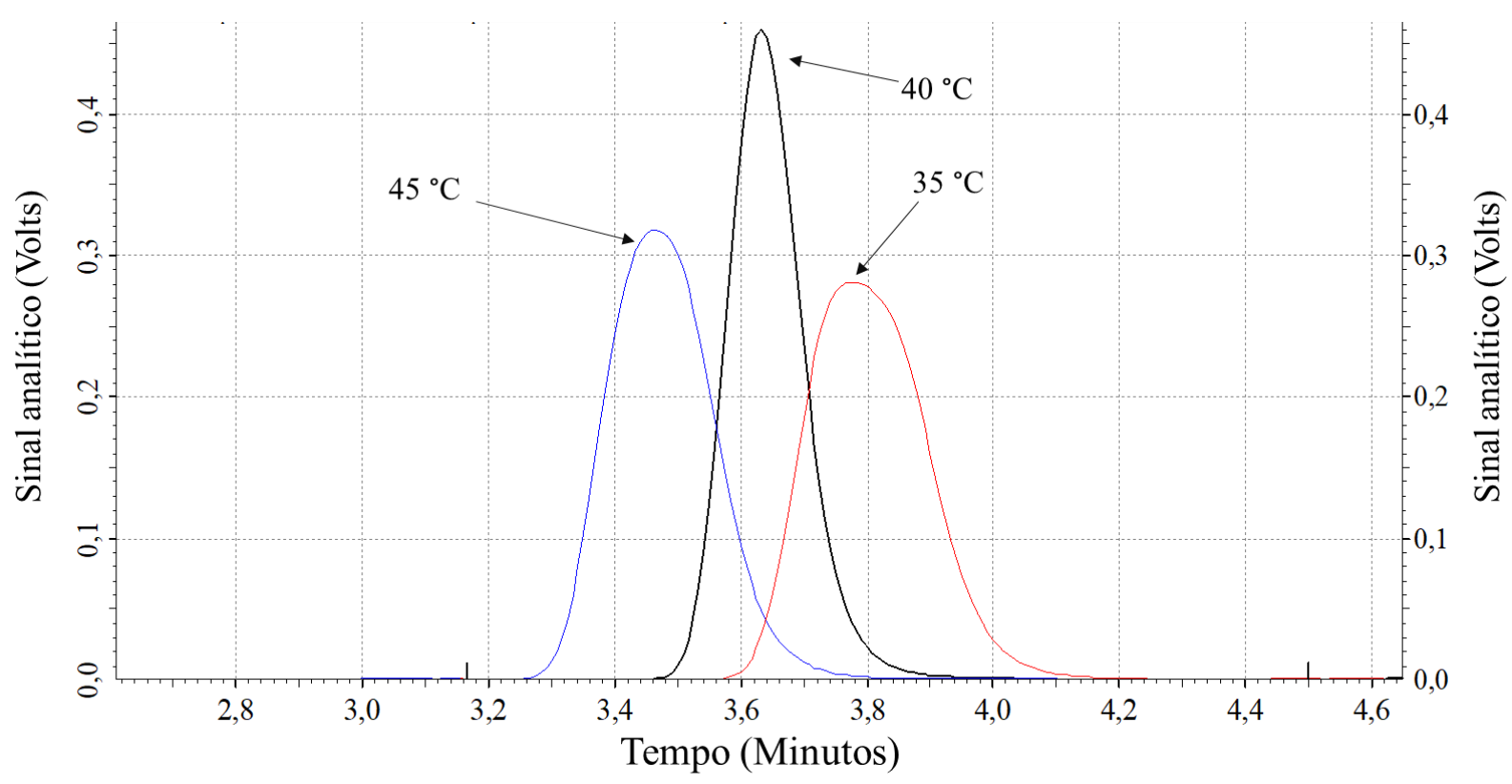

Fonte: $\mathrm{O}$ autor.

Para verificar a seletividade ${ }^{8}$ do método utilizou-se a técnica de superposição ${ }^{9}$ de matriz, e para isso realizou-se a injeção de amostras de meio de cultura isentas do analito (Figura 5.4) e amostras de 4-NF em água ultrapurificada (Figura 5.5). Por meio da comparação dos cromatogramas foi possível verificar que o tempo de retenção de nenhum interferente coincidiu com o composto de interesse (4-NF).

\footnotetext{
${ }^{8}$ A seletividade de um método instrumental reflete a capacidade de avaliar, de maneira inequívoca, as substâncias em exame na presença de outros compostos que podem interferir com a sua determinação, assim, a seletividade deve garantir que o pico de resposta seja exclusivamente do composto de interesse (RIBANI et al., 2004).

${ }^{9} \mathrm{O}$ método de superposição de matriz ("matrix-matched") consiste na adição do padrão da substância de interesse em uma matriz similar à da amostra, isenta da substância, e construção do gráfico de calibração relacionando as áreas obtidas com as concentrações dos padrões. Este método é usado para compensar o efeito da matriz ou de possíveis interferentes e é de grande importância em determinações quando a matriz pode interferir na concentração, extração, separação ou detecção da substância de interesse (RIBANI et al., 2004).
} 
Figura 5.4 - Cromatograma do meio de cultura em coluna cromatográfica C-8 (Agilent ${ }^{\circledR}$ ) com fluxo de eluição de $0,8 \mathrm{~mL} \mathrm{~min}^{-1}$, temperatura de $40^{\circ} \mathrm{C}$ e acetonitrila/água na proporção 90:10 $(\mathrm{v} / \mathrm{v})$ como fase móvel.

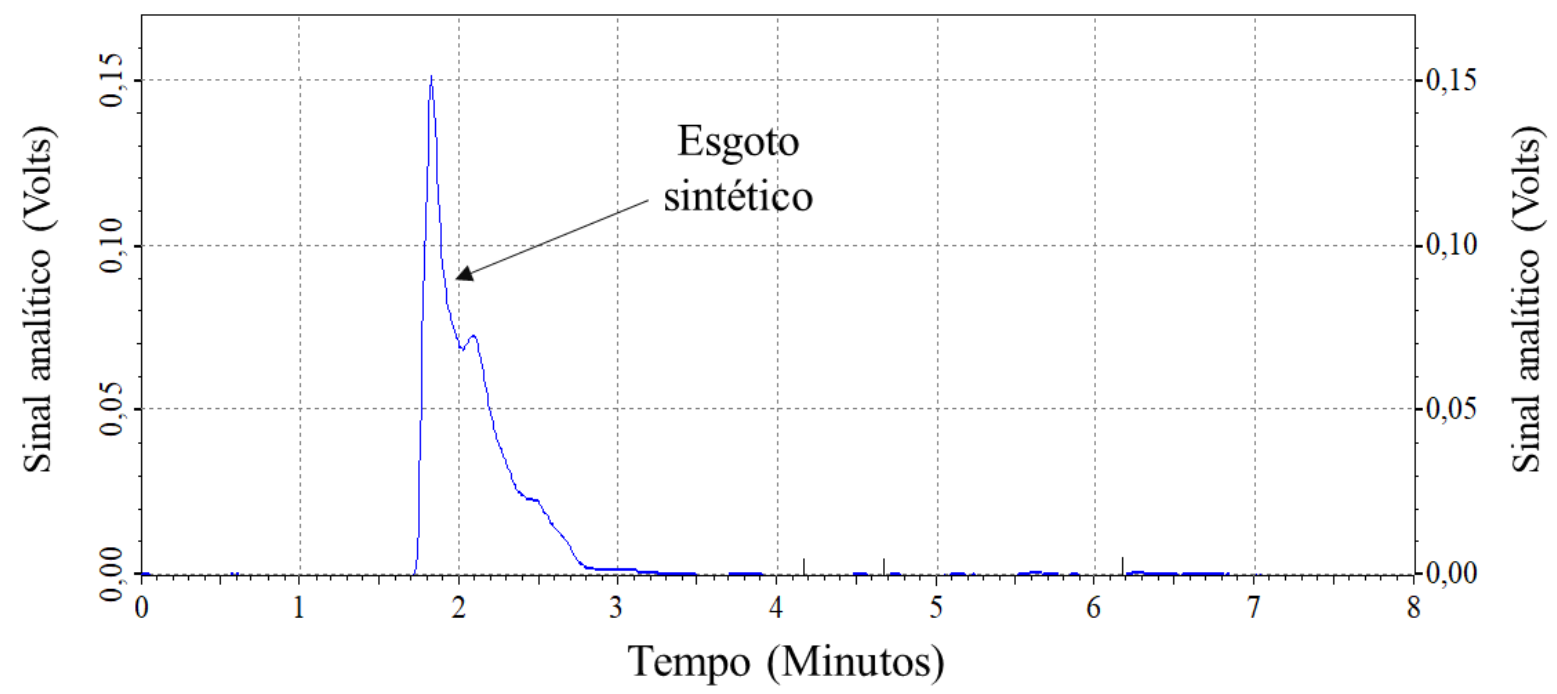

Fonte: O autor.

Figura 5.5 - Cromatograma do 4-NF em água ultra purificada (coluna C-8), eluição isocrática com acetonitrila/água na proporção 90:10 (v/v), fluxo de 1,0 mL $\mathrm{min}^{-1}$, detector com comprimentos de onda em $220 \mathrm{~nm}\left(\lambda_{\text {exc }}\right)$ e $315 \mathrm{~nm}\left(\lambda_{\text {em }}\right)$ a $40^{\circ} \mathrm{C}$.

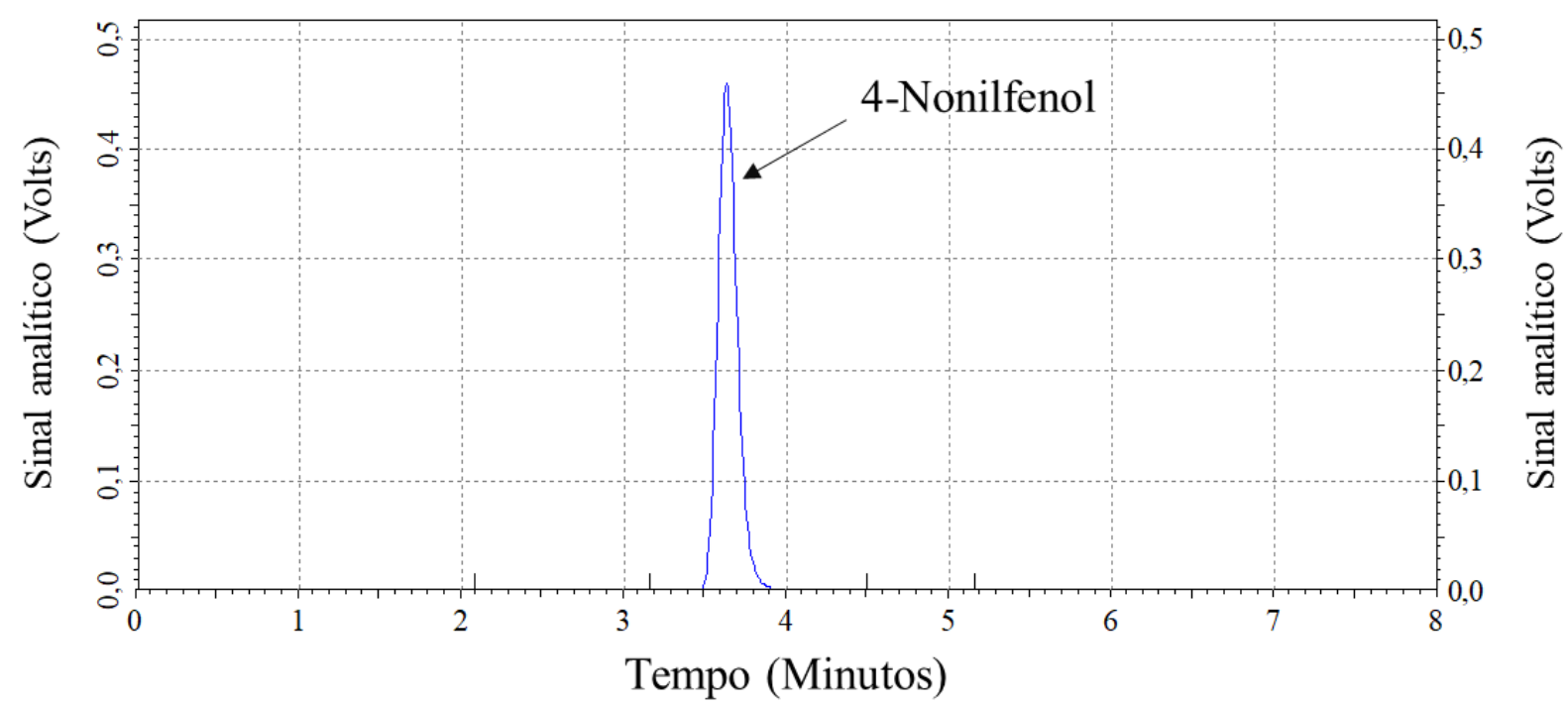

Fonte: $\mathrm{O}$ autor.

O tempo de retenção do 4-NF foi 3,6 minutos, para uma temperatura do forno de $40^{\circ} \mathrm{C}$ e fluxo de eluição de $0,8 \mathrm{~mL} \mathrm{~min}^{-1}$. Após repetidas injeções de metanol, verificou-se que não houve adsorção do 4-NF nos compartimentos do HPLC, sendo obtido cromatograma de detecção do 4-NF com único pico bem definido. A seletividade também foi verificada em 
matrizes complexas reais como esgoto doméstico e água de lavanderia. Em nenhuma das amostras avaliadas houve detecção de picos cromatográficos interferentes no mesmo tempo de detecção do composto de interesse (4-NF).

A proporção de acetonitrila em água foi reduzida para 70:10 (v/v), objetivando a diminuição do uso deste reagente, entretanto, os cromatogramas obtidos não apresentaram boa separação do analito e da matriz referente ao meio de cultura, comprometendo a seletividade do método. Barahona; Turiel; Martín-Esteban (2011) utilizaram uma proporção de acetonitrila/água inferior à usada neste estudo, de 65:35 (v/v); entretanto, os autores utilizaram uma coluna cromatográfica XDB-C8 Agilent $^{\circledR}(3 \mu \mathrm{m}$ e $4,6 \times 150 \mathrm{~mm})$ e um fluxo de eluição de $1,0 \mathrm{~mL} \mathrm{~min}^{-1}$.

Cherniaev; Kondakova; Zyk (2016) avaliaram a detecção de 4-NF utilizando coluna C18 (Discovery $^{\circledR}$ ) com $5 \mu \mathrm{m}$ e $25 \mathrm{~cm} \times 0,46 \mathrm{~cm}$, fluxo de eluição de $0,5 \mathrm{~mL} \mathrm{~min}^{-1}$ e acetonitrila/água como fase móvel na proporção de 90:10 (v/v), similar ao usado neste estudo. Araujo; Bauerfeldt; Cid, (2018) desenvolveram método de detecção do 4-NF usando uma coluna Zorbax Eclipse Plus (3,5 $\mu \mathrm{m}$ e 4,6 × $100 \mathrm{~mm})$ da Agilent ${ }^{\circledR}$, com fluxo de eluição de 1,0 $\mathrm{mL} \min ^{-1}$ e acetonitrila/água na proporção de 90:10 (v/v).

Portanto, não existe unanimidade nos parâmetros de determinação do 4-NF e a eficiência do método varia de acordo com a marca dos equipamentos e reagentes usados, podendo atingir, no máximo uma proximidade dos parâmetros usados e variando os limites de detecção bem como o tempo de corrida cromatográfica (RIBANI et al., 2004; EPA, 2014b). Cada método deve ser desenvolvido para atender as necessidades específicas de cada estudo e estar relacionada com cada matriz a ser utilizada. Neste estudo, especificamente, desenvolvimento de método analítico cromatográfico utilizando meio de cultura, para a detecção do 4-NF em reatores anaeróbios tanto em batelada quando de fluxo continuo.

O aumento do volume de injeção pode ser uma alternativa para alcançar menores concentrações do analito (RIBANI et al., 2004), assim, o volume de injeção foi aumentado e as áreas dos cromatogramas comparadas quanto à altura do pico e sua largura. Para o teste do volume de injeção, foram avaliadas três concentrações diferentes de 4-NF, até que se pudesse obter a detecção na menor concentração testada. Para isso foi utilizada a coluna cromatográfica C-8 (Agilent ${ }^{\circledR}$ ), fluxo de eluição de $0,8 \mathrm{~mL} \mathrm{~min}^{-1}$, acetonitrila/água na proporção de 90:10 (v/v) como fase móvel e temperatura do forno de $40^{\circ} \mathrm{C}$. Estes valores foram fixados de acordo com os testes anteriormente explicitados. Os volumes de injeção testados foram $30 \mu \mathrm{L}, 50 \mu \mathrm{L}$ e 100 $\mu \mathrm{L}$, para as concentrações nominais de 4-NF de $2 \mu \mathrm{g} \mathrm{L}^{-1}, 5 \mu \mathrm{g} \mathrm{\textrm {L } ^ { - 1 }}$ e $60 \mu \mathrm{g} \mathrm{L} \mathrm{L}^{-1}$. Os valores de 
verificados para as áreas cromatográficas do teste de volume de injeção estão dispostos na Tabela 5.2.

Tabela 5.2 - Valores do teste de detecção de 4-NF com variação do volume de injeção, para coluna cromatográfica C-8 $\left(\right.$ Agilent $^{\circledR}$ ), temperatura de $40^{\circ} \mathrm{C}$, fluxo de eluição de $0,8 \mathrm{~mL} \mathrm{~min}^{-1}$ e acetonitrila/água na proporção de 90:10 (v/v) como fase móvel.

\begin{tabular}{cccccc}
\hline $\begin{array}{c}\text { 4-NF* } \\
\left(\mu \mathrm{L} \mathrm{L}^{-1}\right)\end{array}$ & $\begin{array}{c}\text { Volume de } \\
\text { injeção }(\mu \mathrm{L})\end{array}$ & $\begin{array}{c}\text { Temperatura } \\
\left({ }^{\circ} \mathrm{C}\right)\end{array}$ & $\begin{array}{c}\text { Pressão } \\
\left(\mathrm{kgf} \mathrm{cm}^{-2}\right)\end{array}$ & $\begin{array}{c}\text { Tempo de } \\
\text { retenção }(\mathrm{min})\end{array}$ & Área \\
\hline \multirow{2}{*}{2} & 30 & 40 & 17 & 3,63 & 32.548 \\
& 50 & 40 & 17 & 3,64 & 48.275 \\
& 100 & 40 & 17 & 3,62 & 91.199 \\
5 & 30 & 40 & 17 & 3,63 & 74.414 \\
& 50 & 40 & 17 & 3,63 & 100.022 \\
& 100 & 40 & 17 & 3,63 & 193.042 \\
& 30 & 40 & 17 & 3,63 & 668.593 \\
& 50 & 40 & 17 & 3,63 & 1.108 .251 \\
& 100 & 40 & 17 & 3,63 & 2.192 .975 \\
\hline
\end{tabular}

* Concentração teórica de 4-NF em água ultrapura.

A aumento do volume de injeção proporcionou alteração da área cromatográfica para todas as concentrações testadas, assim quanto maior o volume injetado maior a área cromatográfica. Para o aumento do volume de injeção de 30 para $50 \mu \mathrm{L}$ (40\% de aumento), foram verificadas áreas de 32.548 e 48.275 , respectivamente, indicando um aumento de $33 \%$ da área para a concentração nominal de 4-NF de $2 \mu \mathrm{g} \mathrm{L} \mathrm{L}^{-1}$. Considerando o aumento do volume de injeção de 50 para $100 \mu \mathrm{L}$, o percentual médio de aumento da área cromatográfica foi $48 \%$ para as concentrações de $2 \mu \mathrm{g} \mathrm{L}^{-1}, 5 \mu \mathrm{g} \mathrm{L} \mathrm{L}^{-1}$ e $60 \mu \mathrm{g} \mathrm{L}^{-1}$, próximo ao aumento percentual do volume de injeção (50\%), indicando linearidade do aumento da área cromatográfica com aumento do volume de injeção. A comparação entre os cromatogramas com variação do volume de injeção para a concentração de $60 \mu \mathrm{g} \mathrm{L} \mathrm{L}^{-1}$ podem ser observados na Figura 5.6. 
Figura 5.6 - Cromatogramas de 4-Nonilfenol sob diferentes volumes de Injeção para coluna cromatográfica C-8 $\left(\right.$ Agilent $^{\circledR}$ ), temperatura de $40^{\circ} \mathrm{C}$, fluxo de eluição de $0,8 \mathrm{~mL} \mathrm{~min}^{-1}$ e acetonitrila/água na proporção de 90:10 (v/v) como fase móvel.

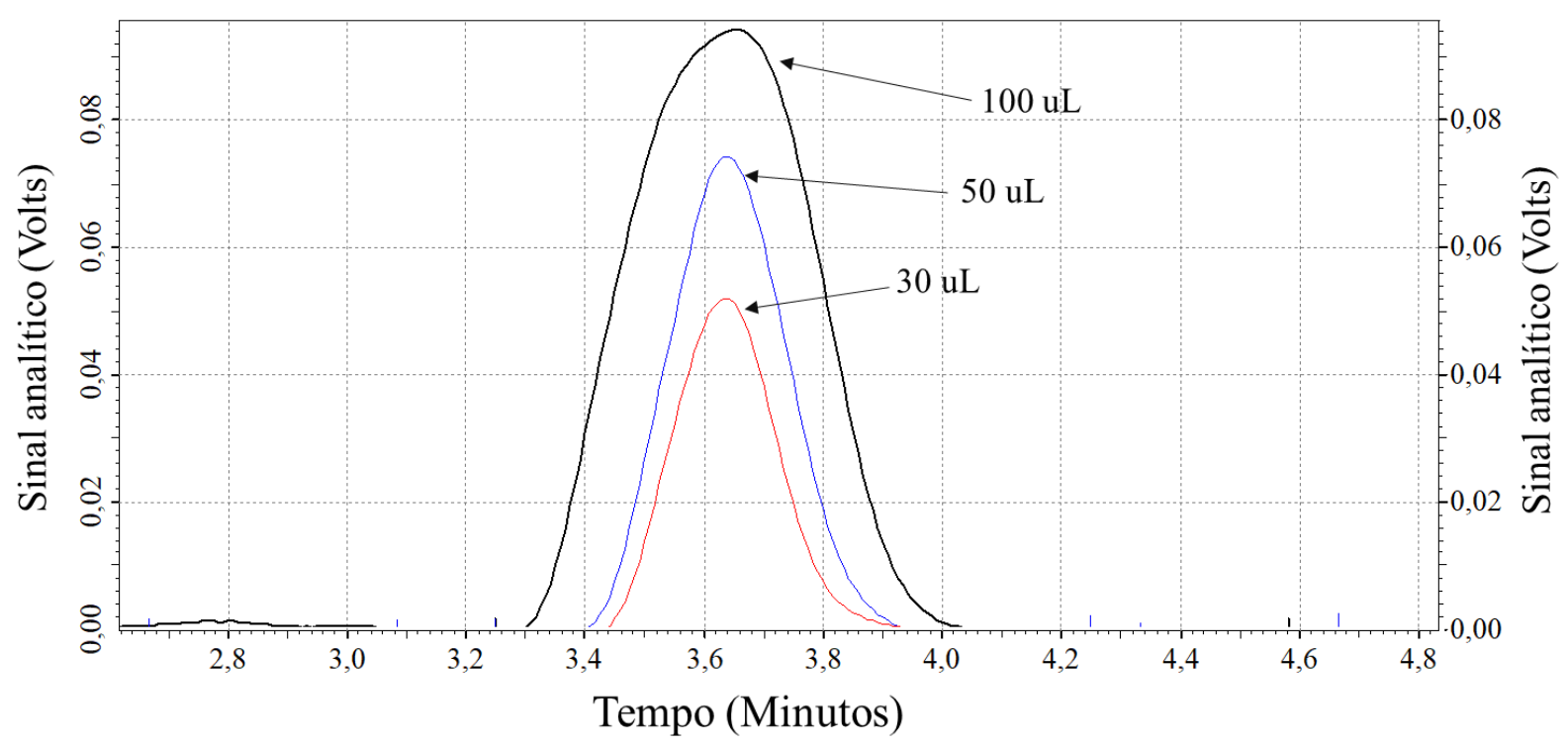

Fonte: $\mathrm{O}$ autor.

Assim, o volume de Injeção foi fixado em $100 \mu \mathrm{L}$. O aumento do volume de Injeção é alternativa para aumentar a detecção e quantificação de compostos em baixas concentrações, como o caso do 4-NF, tanto em reatores biológico, quanto em sistemas aquáticos como verificados por (GORGA et al., 2015)

Visando aprimorar a detecção de 4-NF, foram testados os comprimentos de onda do detector de fluorescência $\left(\mathrm{RF} 10 \mathrm{~A}_{\mathrm{xl}}\right)$ para excitação e emissão de acordo com valores relatados na literatura por Liu et al. (2003) e Cruceru et al. (2012) $\left(\lambda_{\mathrm{exc}}=220 \mathrm{~nm}\right.$ e $\left.\lambda_{\mathrm{em}}=315 \mathrm{~nm}\right)$; Barahona; Turiel e Martín-Esteban (2011) $\left(\lambda_{\mathrm{exc}}=226 \mathrm{~nm}\right.$ e $\left.\lambda_{\mathrm{em}}=305 \mathrm{~nm}\right)$; Cherniaev; Kondakova e Zyk (2016) $\left(\lambda_{\mathrm{exc}}=230 \mathrm{~nm}\right.$ e $\left.\lambda_{\mathrm{em}}=320 \mathrm{~nm}\right)$; e Bennie et al. (1997) $\left(\lambda_{\mathrm{exc}}=230 \mathrm{~nm}\right.$ e $\left.\lambda_{\mathrm{em}}=300 \mathrm{~nm}\right)$. A partir destes comprimentos de onda, os novos valores testados foram $\lambda_{\mathrm{exc}}=$ $225 \mathrm{~nm}$ e $\lambda_{\mathrm{em}}=305 \mathrm{~nm} ; \lambda_{\mathrm{exc}}=225 \mathrm{~nm}$ e $\lambda_{\mathrm{em}}=315 \mathrm{~nm} ;\left(\lambda_{\mathrm{exc}}=220 \mathrm{~nm}\right.$ e $\left.\lambda_{\mathrm{em}}=305 \mathrm{~nm}\right)$. Para que a variação na área dos picos cromatográficos fosse provocada exclusivamente pela variação dos comprimentos de onda, foram fixados os parâmetros de fluxo de eluição de $0,8 \mathrm{~mL} \mathrm{~min}{ }^{-1}$, temperatura de $40^{\circ} \mathrm{C}$, volume de Injeção de $100 \mu \mathrm{L}$ e acetonitrila/água na proporção de 90:10 (v/v). O teste de comprimentos de onda foi realizado usando uma solução de 4-NF com concentração nominal de $60 \mu \mathrm{g} \mathrm{L} \mathrm{L}^{-1}$ em água ultrapura. 
A maior área cromatográfica (3.339.835) foi alcançada pelos comprimentos de onda de $\lambda_{\text {exc }}=225 \mathrm{~nm}$ e $\lambda_{\mathrm{em}}=305 \mathrm{~nm}$, seguido pelos parâmetros usados por Barahona; Turiel e MartínEsteban (2011), no qual estes obtiveram área cromatográfica de 3.271.197. A comparação das áreas obtidas com a variação dos comprimentos de onda do detector pode ser verificada na Tabela 5.3.

Tabela 5.3 - Valores do teste de determinação de 4-NF com variação dos comprimentos de onda do detector, para coluna cromatográfica C-8 $\left(\right.$ Agilent $^{\circledR}$ ), temperatura de $40^{\circ} \mathrm{C}$, volume de Injeção de $100 \mu \mathrm{L}$, fluxo de eluição de $0,8 \mathrm{~mL} \mathrm{~min}^{-1}$ e acetonitrila/água na proporção de 90:10 (v/v) como fase móvel.

\begin{tabular}{|c|c|c|c|c|}
\hline \multirow{2}{*}{ Referência } & \multicolumn{2}{|c|}{ Comprimento de onda (nm) } & \multirow{2}{*}{$\begin{array}{l}\text { Tempo de } \\
\text { retenção (min) }\end{array}$} & \multirow{2}{*}{ Área } \\
\hline & Excitação & Emissão & & \\
\hline CRUCERU et al., (2012) & 220 & 315 & 3,63 & 2.192 .975 \\
\hline LIU et al., (2003) & & & & \\
\hline $\begin{array}{l}\text { CHERNIAEV; } \\
\text { KONDAKOVA; ZYK, (2016) }\end{array}$ & 230 & 320 & 3,61 & 1.810 .991 \\
\hline $\begin{array}{l}\text { BARAHONA; TURIEL; } \\
\text { MARTÍN-ESTEBAN, (2011) }\end{array}$ & 226 & 305 & 3,62 & 3.271 .197 \\
\hline BENNIE et al., (1997) & 230 & 300 & 3,62 & 3.075 .047 \\
\hline Neste estudo* & 220 & 305 & 3,61 & 2.909 .518 \\
\hline Neste estudo * & 225 & 305 & 3,62 & 3.339 .835 \\
\hline Neste estudo * & 225 & 315 & 3,61 & 1.443 .753 \\
\hline
\end{tabular}

* Valores não relatados na literatura.

Avaliando os valores obtidos usando os comprimentos de onda já descritos na literatura, a menor área cromatográfica (1.810.991) foi verificada usando os valores de $\lambda$ de $230 \mathrm{~nm}$ para excitação e $320 \mathrm{~nm}$ para emissão, os quais foram relatados por Cherniaev; Kondakova e Zyk (2016). Os cromatogramas obtidos para todos os comprimentos de onda testados podem ser observados na Figura 5.7. 
Figura 5.7 - Cromatogramas de 4-NF com variação dos comprimentos de onda do detector, para coluna cromatográfica C-8 $\left(\right.$ Agilent $\left.^{\circledR}\right)$, temperatura de $40^{\circ} \mathrm{C}$, volume de injeção de $100 \mu \mathrm{L}$, fluxo de eluição de $0,8 \mathrm{~mL} \mathrm{~min}^{-1}$ e acetonitrila/água na proporção de 90:10 (v/v) como fase móvel.

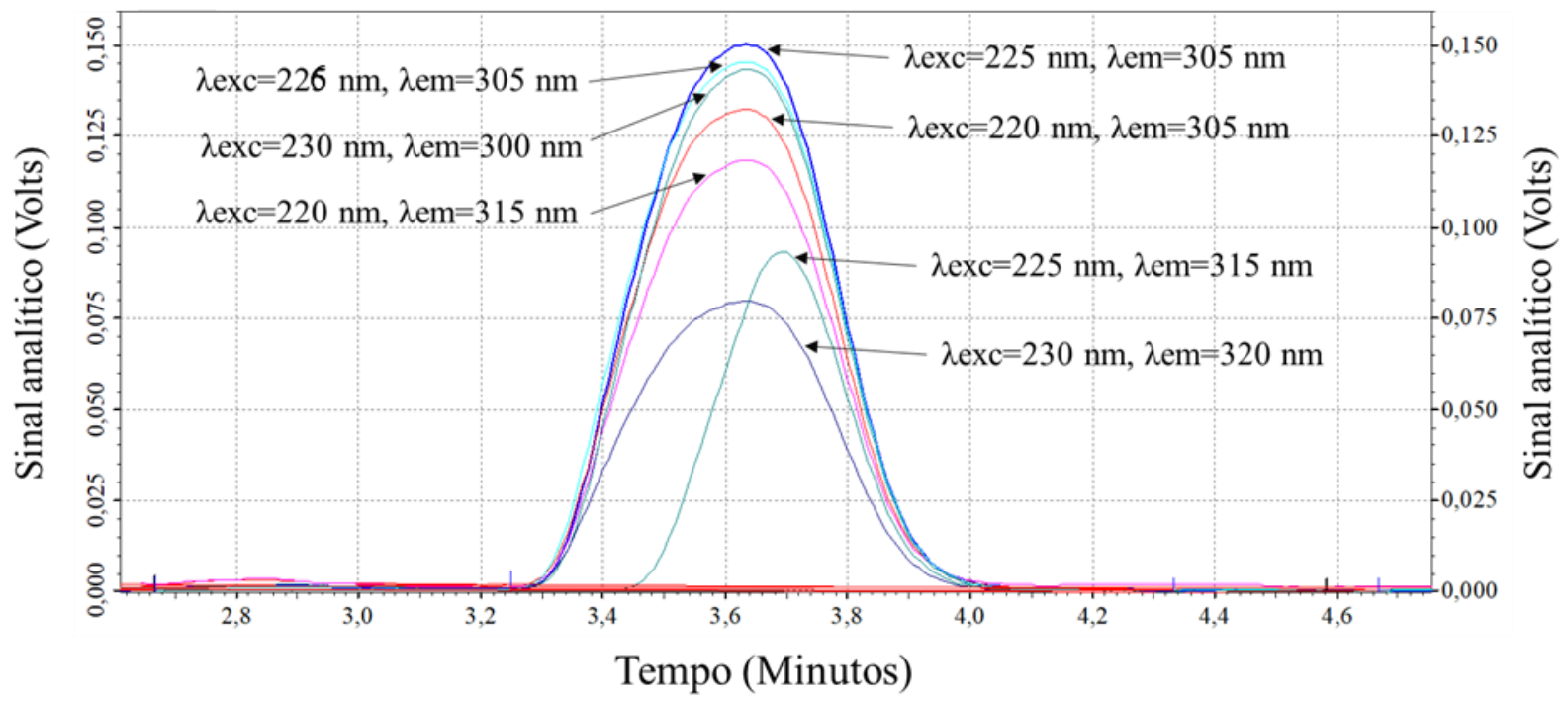

Fonte: $\mathrm{O}$ autor.

Portanto, os parâmetros cromatográficos aprimorados para a determinação de 4-NF em HPLC usando coluna cromatográfica C-8 $\left(\right.$ Agilent $\left.^{\circledR}\right)$ como fase estacionária foram o fluxo de eluição de $0,8 \mathrm{~mL} \mathrm{~min}{ }^{-1}$, temperatura do forno de $40^{\circ} \mathrm{C}$, volume de injeção de $100 \mu \mathrm{L}$, proporção do eluente acetonitrila/água de 90:10 (v/v) e comprimentos de onda para o detector de fluorescência de $\lambda_{\text {exc }}=225 \mathrm{~nm}$ e $\lambda_{\mathrm{em}}=305 \mathrm{~nm}$, o que proporcionou um método simples, rapico e prático para a determinação do surfactante não iônico em matriz complexa de reatores anaeróbios.

\subsubsection{Preparo de amostras}

O método cromatográfico testado neste estudo visa a quantificação do 4-NF em reatores biológicos usados no tratamento de águas residuárias, portanto, com alto teor de impurezas. As amostras analisadas em HPLC precisam atender a um grau pureza para que a concentração do analito não seja subestimada ou haja o comprometimento do aparato instrumental. Anterior a análise, é recomendado que cada amostra seja filtrada em membrana com porosidade $>0,2 \mu \mathrm{m}$ a fim de remover sólidos em suspensão ou material particulado presente no meio liquido. 
Para avaliar a recuperação de 4-NF após filtração, foram testadas membranas de celulose, celulose regenerada e fibra de vidro. As membranas de filtração a vácuo indicaram percentual médio de adsorção de 4-NF de $85 \%$, inviabilizando seu uso. A comparação entre os valores de 4-NF antes da filtração (Controle) e recuperados após a filtração a vácuo podem ser verificados na Tabela 5.4.

Tabela 5.4 - Percentual de adsorção de 4-NF em membranas de filtração.

\begin{tabular}{ccccc}
\hline \multirow{2}{*}{ Réplicas } & \multicolumn{4}{c}{ Nonilfenol $\left(\mu \mathrm{g} \mathrm{L}^{-1}\right)$} \\
\cline { 2 - 5 } & Controle*1 $^{*}$ Celulose*2 $^{* 2}$ & $\begin{array}{c}\text { Celulose } \\
\text { Regenerada*3 }\end{array}$ & Fibra de Vidro*4 $^{* 4}$ \\
\hline 1 & 3118,03 & 356,34 & 584,69 & 163,56 \\
3 & 3057,08 & 166,32 & 578,52 & 664,62 \\
4 & 2932,21 & 301,87 & 542,70 & 742,03 \\
5 & 2953,22 & 351,27 & 532,08 & 705,39 \\
Média & $2999,27 \pm 74,95$ a & $270,49 \pm 83,11 \mathrm{c}$ & $480,51 \pm 159,25 \mathrm{bc}^{*}$ & $606,22 \pm 223,57 \mathrm{~b}$ \\
\multicolumn{2}{c}{ Adsorção $(\%)$} & 90,98 & 83,98 & 79,79 \\
\hline
\end{tabular}

\footnotetext{
* Médias seguidas da mesma letra não diferem pelo teste de Tukey, a 5\% de probabilidade de erro.

*1 Solução de 4-NF em meio de cultura (Tabela 4.2 e Tabela 4.3)

*2 Membrana de acetato de celulose 0,2 $\mu \mathrm{m}$.

*3 Membrana de Celulose Regenerada 0,2 $\mu \mathrm{m}$.

*4 Membrana de fibra de vidro 0,2 $\mu \mathrm{m}$.
}

Tendo em vista os elevados percentuais de adsorção (80\%, 84\% e 91\%) de 4-NF para todas as membranas de filtração testadas, fez-se necessário o uso de método alternativo para purificação de amostras. Assim, para o procedimento de purificação da amostra e recuperação do 4-NF foram testados diferentes sistemas de condicionamento e eluição em cartuchos de extração em fase sólida (SPE).

Todos os cartuchos (C18-ODS, C18-ec e Alumina) foram testados em relação aos solventes de condicionamento (etanol, metanol e água ultrapurificada) e eluentes (etanol e metanol). O mesmo procedimento de condicionamento e eluição foi aplicado em todos os cartuchos testados supracitado, entretanto, para os cartuchos de Alumina e C18-ec não foram obtidas boa recuperação. Já para o cartucho C18-ODS foi observada recuperação de $101 \%$ e, 
portanto, usado para a validação do método de determinação do 4-NF Os dados de recuperação para o cartucho C18-ODS estão descritos na Tabela 5.5.

Tabela 5.5 - Recuperação de 4-NF em cartucho C18-ODS.

\begin{tabular}{|c|c|c|}
\hline \multicolumn{2}{|c|}{ Nonilfenol $\left(\mu g \mathrm{~L}^{-1}\right)$} & \multirow{2}{*}{ Recuperação (\%) } \\
\hline Controle* & Recuperado** & \\
\hline $317,20 \pm 0,33$ & $319,60 \pm 28,77$ & $100,77 \pm 9,14$ \\
\hline
\end{tabular}

* Solução de 4-NF em meio de cultura (Tabela 4.2 e Tabela 4.3)

** Após condicionamento em cartucho C18-ODS.

O método de extração em cartucho que apresentou as melhores uniformidades dos picos cromatográficos foi com condicionamento do cartucho em metanol ( $2 \mathrm{~mL})$ e eluição com etanol $(1 \mathrm{~mL})$ seguida de lavagem com água ultrapurificada $(1 \mathrm{~mL})$. Após passar pelo cartucho a amostra não apresentou concentração residual de 4-NF, indicando que o composto alvo ficou adsorvido ao cartucho. Após a primeira eluição $(1 \mathrm{~mL}$ de etanol seguida de $1 \mathrm{~mL}$ de água ultrapura), toda a concentração de 4-NF adicionado ao cartucho foi eluída para a fase líquida. Para confirmar a eficiência do método de extração, uma segunda eluição foi executada, entretanto, a presença do analito não foi verificada indicando que todo o composto (4-NF) foi extraído na primeira eluição. Os cromatrogramas referentes aos testes de eluição podem ser verificados na Figura 5.8.

Figura 5.8 - Cromatogramas do método de extração em fase sólida para cartucho C18-ODS.

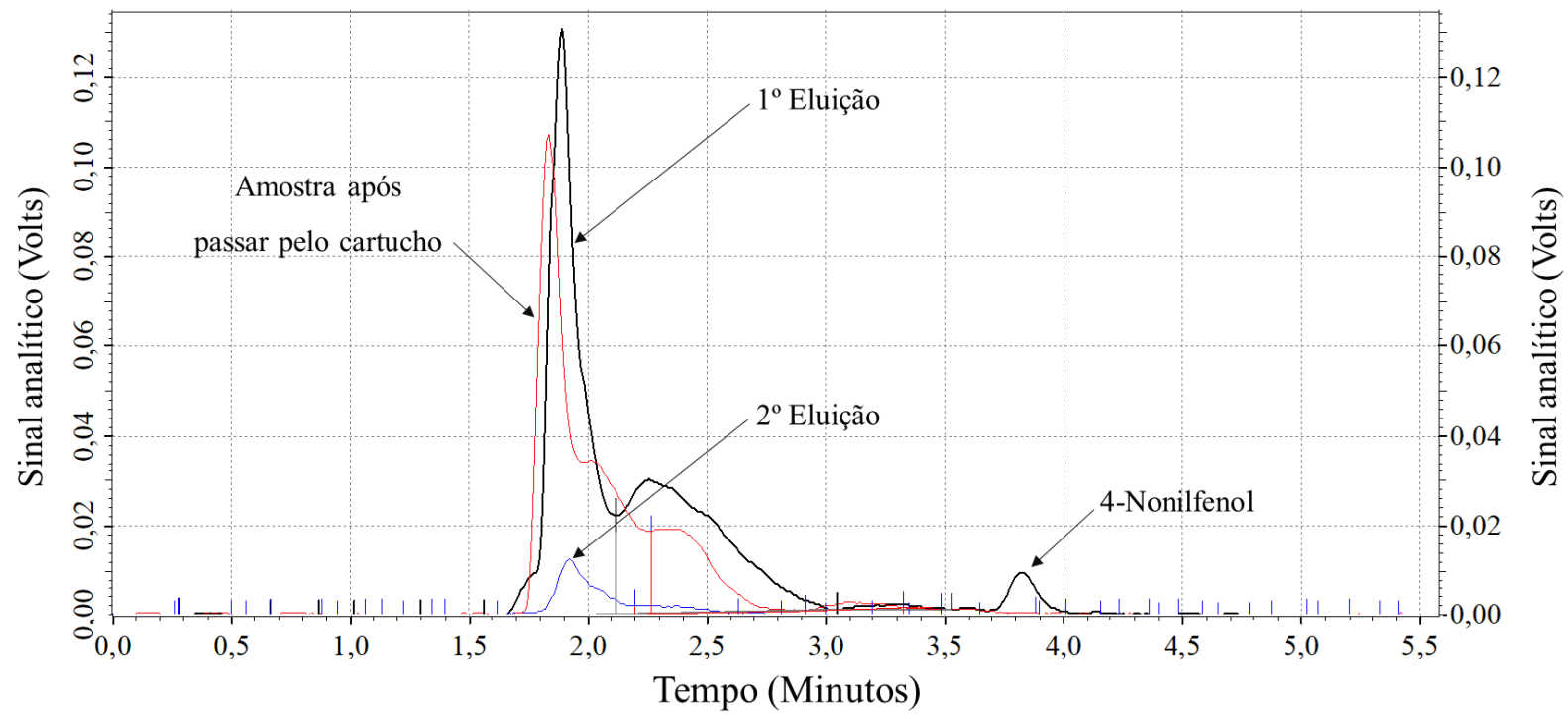

Fonte: $\mathrm{O}$ autor. 
Assim, o procedimento de extração e purificação do 4-NF em cartucho de SPE (C18ODS) foi: condicionar o cartucho com $2 \mathrm{~mL}$ de $\mathrm{MeOH}$ (metanol); adicionar $2 \mathrm{~mL}$ da amostra contendo 4-NF; eluir com $1 \mathrm{~mL}$ de EtOH (etanol) seguido de $1 \mathrm{~mL}$ de água ultra purificada, (Figura 5.9).

Figura 5.9 - Esquema de purificação de amostra em cartucho SPE C18-ODS.
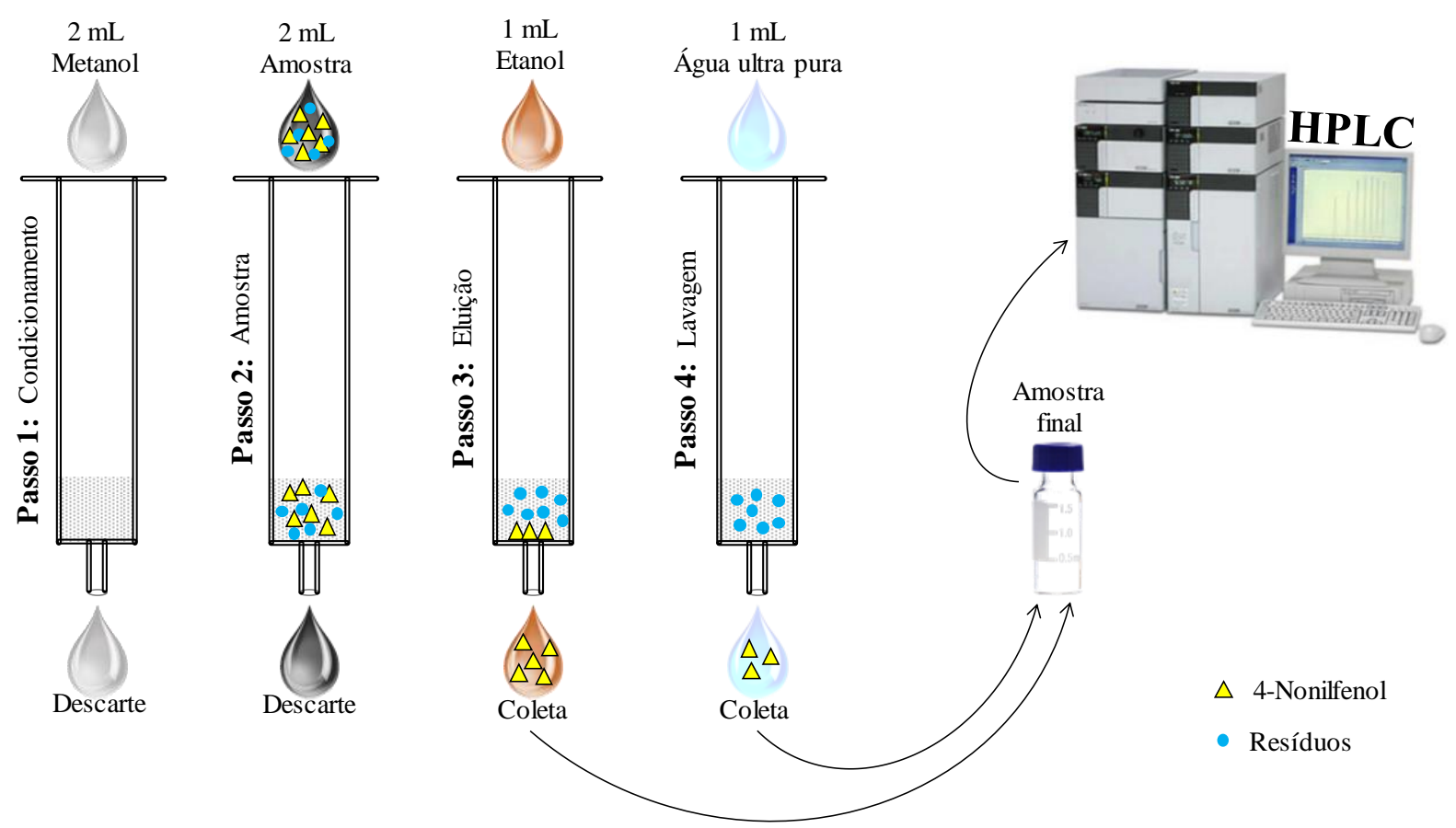

$\triangle$ 4-Nonilfenol

- Resíduos

Fonte: $\mathrm{O}$ autor.

LIU et al., (2016) usaram cartuchos $\left(\right.$ Oasis $^{\circledR}$ ) de extração em fase sólida SPE (Solid Phase Exctraction) para concentrar amostras $(1000 \mathrm{~mL})$ de águas superficiais visando quantificar a concentração de 4-NF; os autores condicionaram os cartuchos com metanol e eluíram as amostras concentradas com o mesmo solvente.

Lu; Reif e Gan (2015) utilizaram cartuchos SPE (Thermo Scientific ${ }^{\circledR}$ ) para monitorar a biodegradação de 4-NF em reatores de lodo ativado, os cartuchos foram condicionados com 25 $\mathrm{mL}$ de hexano e eluídos com $35 \mathrm{~mL}$ de cloreto de metileno, diferente da condição usada no presente estudo.

Lee et al. (2013) avaliaram os parâmetros de qualidade da água e ocorrência de 4-NF em rios com pontos de lançamento de efluentes e usaram cartuchos LiChrolut RP-18 (SigmaAldrich $^{\circledR}$ ), para a etapa de condicionamento foi usada $45 \mathrm{~mL}$ de solução de metanol/acetona na proporção de 1:1(v/v) e $10 \mathrm{~mL}$ de água ultrapurificada. Após a adição da amostra o cartucho foi eluído com $15 \mathrm{~mL}$ de metanol/acetona na proporção de 1:1 (v/v) e $5 \mathrm{~mL}$ de diclorometano. 
Os eluentes das amostras foram concentrados com fluxo de nitrogênio e o volume final aferido para $1 \mathrm{~mL}$ com acetonitrila.

Portanto, uma variedade de estratégias pode ser adotada para realizar o preparo de amostras e determinação de 4-NF por Cromatografia Líquida de Alta Eficiência (HPLC). Neste estudo foram priorizadas alternativas que proporcionassem menor consumo de reagentes e manipulação de amostras visando custo e os princípios de química verde, ocasionando um método compacto, viável, estável, confiável e adaptado a rotina de laboratório, podendo ser aplicado a matrizes complexas como afluentes e efluentes de reatores biológicos.

\subsubsection{Validação do método}

Aa matrizes reais complexas contendo surfactantes, como esgoto doméstico e água residuária de lavanderia, podem criar interferências na análise por HPLC, as quais influenciam o sinal e podem interferir na concentrações dos analitos de interesse, resultando na competição entre os componentes da matriz e os analitos alvo (TRUFELLI et al., 2011). Por meio dos testes anteriormente realizados verificou-se a presença destes interferentes, entretanto, para o método isocrático com acetonitrila/água (90:10 v/v), não foi verificado nenhuma sobreposição de pico em relação ao tempo de retenção do surfactante não iônico 4-NF.

Para a obtenção dos parâmetros de validação do método desenvolvido foram injetadas 15 concentrações diferentes do surfactante 4-Nonilfenol $\left(55,6 \mu \mathrm{g} \mathrm{L}^{-1} ; 83,3 \mu \mathrm{g} \mathrm{L}^{-1} ; 100,0 \mu \mathrm{g} \mathrm{L}\right.$ 1; 166,7 $\mu \mathrm{g} \mathrm{L}{ }^{-1}, 200 \mu \mathrm{g} \mathrm{L}^{-1} ; 250 \mu \mathrm{g} \mathrm{L}^{-1} ; 375 \mu \mathrm{g} \mathrm{L}^{-1} ; 500 \mu \mathrm{g} \mathrm{L}^{-1} ; 625 \mu \mathrm{g} \mathrm{L}^{-1} ; 750 \mu \mathrm{g} \mathrm{L}^{-1} ; 875 \mu \mathrm{g}$ $\mathrm{L}^{-1} ; 1250 \mu \mathrm{g} \mathrm{L}^{-1} ; 1750 \mu \mathrm{g} \mathrm{L}^{-1} ; 2250 \mu \mathrm{g} \mathrm{L}^{-1} ; 2750 \mu \mathrm{g} \mathrm{L}^{-1}$ e $\left.3250 \mu \mathrm{g} \mathrm{L}^{-1}\right)$ e a relação matemática entre o sinal analítico detectado (áreas do pico cromatográfico) e a concentração teórica (nominal) foi usada para confeccionar curva analítica, a qual pode ser observada na Figura 5.10. 
Figura 5.10 - Curva analítica de quantificação de 4-Nonilfenol em HPLC.

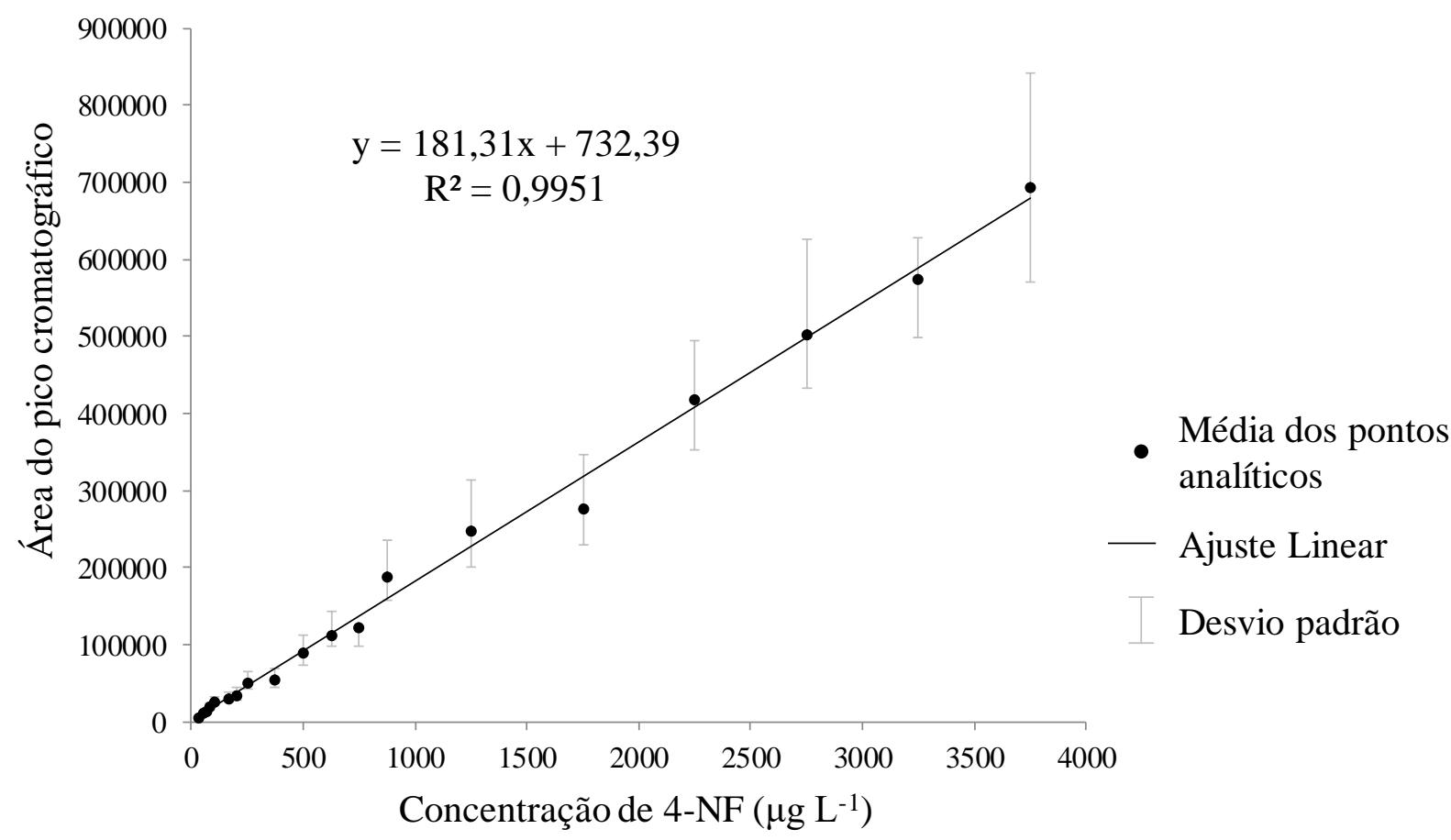

Fonte: $\mathrm{O}$ autor.

A curva analítica foi obtida para concentrações entre $55,6 \mu \mathrm{g} \mathrm{L}^{-1}$ e $3.250 \mu \mathrm{g} \mathrm{L}^{-1}$, com coeficientes de regressão linear de 0,9951 . Todos os valores de desvio padrão relativo (RSD\%) para 4-Nonilfenol obtidos foram inferiores a 20\%, atendendo aos parâmetros recomendados por Ribani et al. (2004) e EPA (2014b). O desvio padrão relativo para cada sinal analítico médio estão dispostos na Tabela 5.6.

Os limites de Detecção ${ }^{10}$ e Quantificação ${ }^{11}$ foram calculados com base na curva analítica utilizando as equações descritas por Ribani et al. (2004) no ítem 4.6.6.3 (Limite de Detecção) e 4.6.6.4 (Limite de Quantificação). Os limites de detecção e quantificação calculados com base na curva analítica foram $13,3 \mu \mathrm{g} \mathrm{\textrm {L } ^ { - 1 } \mathrm { e }} 40,4 \mu \mathrm{g} \mathrm{\textrm {L } ^ { - 1 }}$, respectivamente.

\footnotetext{
${ }^{10} \mathrm{O}$ limite de detecção (LD) indica a menor concentração da substância que pode ser detectada, mas não necessariamente quantificada, utilizando determinado procedimento experimental (RIBANI et al., 2004).

${ }^{11} \mathrm{O}$ limite de quantificação (LQ) é a menor concentração do analito que pode ser medida, utilizando determinado procedimento experimental (RIBANI et al., 2004).
} 
Tabela 5.6 - Valores referentes ao sinal analítico médio, desvio padrão e desvio padrão relativo da curva analítica do 4-Nonilfenol.

\begin{tabular}{cccc}
\hline $\begin{array}{c}\text { Concentração Nominal } \\
\left(\mu \mathrm{g} \mathrm{L}^{-1}\right)\end{array}$ & Sinal analítico médio & Desvio Padrão & RSD $(\%)$ \\
\hline 3.750 & 695.122 & $123.456,89$ & 17,76 \\
3.250 & 574.096 & $74.439,40$ & 12,97 \\
2.750 & 503.139 & $69.301,21$ & 13,77 \\
2.250 & 419.367 & $65.572,61$ & 15,64 \\
1.750 & 277.376 & $46.913,17$ & 16,91 \\
1.250 & 248.868 & $47.223,43$ & 18,98 \\
875 & 187.774 & $30.950,60$ & 16,48 \\
750 & 121.951 & $24.303,20$ & 19,93 \\
625 & 111.498 & $14.211,65$ & 12,75 \\
500 & 88.845 & $14.513,94$ & 16,34 \\
375 & 55.042 & $10.655,09$ & 19,36 \\
250 & 49.713 & $6.725,96$ & 13,53 \\
200 & 33.620 & $5.409,51$ & 16,09 \\
166,7 & 30.947 & $4.716,00$ & 15,24 \\
100,0 & 27.028 & $4.490,62$ & 16,61 \\
83,3 & 19.833 & $2.432,91$ & 12,27 \\
55,6 & 11.126 & 264,95 & 2,38 \\
\hline
\end{tabular}

RSD\% - desvio padrão relativo (coeficiente de variação)

Duarte et al. (2006) desenvolveram método para quantificação do surfactante aniônico LAS em HPLC, foi usada uma coluna C-8 Agilent ${ }^{\circledR}$, fase móvel com metanol/perclorato de sódio e temperatura do forno a $37^{\circ} \mathrm{C}$; os autores verificaram limites médios ${ }^{12}$ de detecção e

\footnotetext{
${ }^{12} \mathrm{O}$ surfactante LAS é constituído por uma mistura de homólogos e o seu método de determinação indica o somatório destes homólogos. Para fim de comparação foram usados os valores médios. Os valores originais verificados por Duarte et al. (2006) para cada homólogo foram 0,37; 0,69; 0,54; e 0,42 $\mathrm{mg} \mathrm{L}^{-1}$ para LD e 1,23; 2,$30 ; 1,80 ;$ e $1,40 \mathrm{mg} \mathrm{L}^{-1}$ para LQ.
} 
quantificação de $505 \mu \mathrm{g} \mathrm{\textrm {L } ^ { - 1 }}$ e $1683^{13} \mu \mathrm{g} \mathrm{\textrm {L } ^ { - 1 }}$, respectivamente. Diferentemente dos verificados no presente estudo, o que pode estar relacionado as características de cada analito.

Araujo; Bauerfeldt e Cid, (2018) desenvolveram método de quantificação de 4-NF em água doce superficial utilizando HPLC, com detecção UV (225 nm), acetonitrila/água (90:10 v:v) como eluente, coluna Zorbax Eclipse Plus (Agilent ${ }^{\circledR}$ ), volume de Injeção de $10 \mu \mathrm{L}$, fluxo de eluição 1,0 mL min ${ }^{-1}$ e verificaram limites de detecção e quantificação de $0,20 \mu \mathrm{g} \mathrm{L}^{-1}$ e 1,15 $\mu \mathrm{g} \mathrm{L} \mathrm{L}^{-1}$, respectivamente. Os valores relatados por Araujo; Bauerfeldt e Cid, (2018) foram inferiores ao encontrados no presente estudo; o que pode estar relacionado as condições cromatográficas usadas e instrumental analítico disponível.

Portanto, a abordagem utilizada neste estudo para quantificar 4-NF em amostras ambientais foi validada avaliando a linearidade da curva analítica, seletividade, limite de detecção, limite de quantificação e recuperação. No método desenvolvido, o 4-NF apresentou cromatograma com um pico bem definido (Figura 5.5), sem interferente da matriz (Figura 5.4). As amostras analisadas por este método necessitam precisam prévia separação utilizando baixos volumes de solventes. Este método é particularmente útil para a quantificação de 4-NF em grande número de amostras, uma vez que o procedimento analítico apresenta seletividade de determinação, simplicidade e curto tempo de análise.

\subsection{Ensaios em Reatores Anaeróbios em Batelada}

Testes com co-substratos em reatores anaeróbios em batelada foram realizados a fim de estimar o potencial metanogênico do inoculo na presença de 4-Nonilfenol. Para tanto, foram realizados ensaios nas seguintes condições: (1) reatores controle com etanol, (2) reatores controle com metanol, (3) reatores controle com fumarato, (4) reatores com adição de 4-NF e etanol, (5) reatores com adição de 4-NF e metanol e (6) reatores com adição de 4-NF e fumarato.

\subsubsection{Remoção de matéria orgânica}

Os ensaios em reatores em bateladas foram monitorados por $217,8 \pm 13,6$ horas para as condições controle (Etanol, Metanol e Fumarato) e 420,4+36,7 horas para ensaios com adição de 4-NF (Etanol+4-NF, Metanol+4-NF e Fumarato+4-NF).

\footnotetext{
${ }^{13}$ Para fim de comparação, os valores originais descritos por Duarte et al. (2006) foram convertidos para $\mu g \mathrm{~L}^{-1}$.
} 
O maior valor de DQO inicial $\left(1305,20 \pm 7,43 \mathrm{mg} \mathrm{L}^{-1}\right)$ foi verificado para o ensaio com adição 4-NF e etanol como co-substrato (Etanol+4-NF) e o menor $\left(883,33 \pm 43,78 \mathrm{mg} \mathrm{L}^{-1}\right)$ para o ensaio Metanol. Para os ensaios controle (sem adição de 4-NF), a maior eficiência de remoção

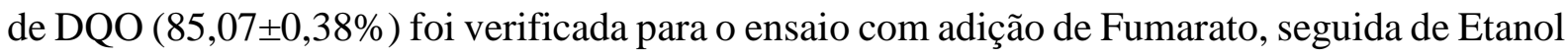
$(82,52 \pm 0,29 \%)$ e Metanol $(77,75 \pm 0,91 \%)$. Nos ensaios com adição de 4-NF a eficiência de remoção de DQO seguiu o mesmo comportamento dos ensaios controle e os valores verificados

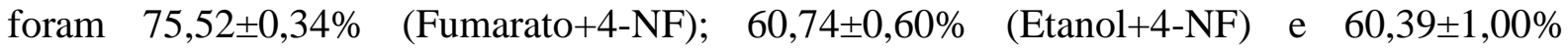
(Metanol+4-NF). Os valores de DQO média inicial, final e eficiência de remoção são apresentados na Tabela 5.7, bem como sua comparação estatística.

Tabela 5.7 - DQO média inicial, final e eficiência de remoção.

\begin{tabular}{|c|c|c|c|}
\hline \multirow{2}{*}{ Ensaios } & \multicolumn{2}{|c|}{ DQO $\left(\mathrm{mg} \mathrm{L}^{-1}\right)$} & \multirow{2}{*}{ Eficiência (\%) } \\
\hline & Inicial & Final & \\
\hline Etanol & $1.183,33 \pm 11,25 \mathrm{c}$ & $208,00 \pm 4,08 \mathrm{~d}$ & $82,52 \pm 0,29 b$ \\
\hline Etanol + 4-NF & $1.305,20 \pm 7,43 \mathrm{a}$ & $512,40 \pm 6,23 \mathrm{a}$ & $60,74 \pm 0,60 \mathrm{e}$ \\
\hline Metanol & $883,33 \pm 43,78 \mathrm{~d}$ & $194,50 \pm 3,11 \mathrm{e}$ & $77,75 \pm 0,91 \mathrm{c}$ \\
\hline Metanol + 4-NF & $914,83 \pm 8,95 \mathrm{~d}^{*}$ & $362,33 \pm 8,62 b$ & $60,39 \pm 1,00 \mathrm{e}$ \\
\hline Fumarato & $1.160,83 \pm 36,66 \mathrm{c}$ & $170,00 \pm 2,45 \mathrm{f}$ & $85,07 \pm 0,38 \mathrm{a}$ \\
\hline Fumarato + 4-NF & $1.242,00 \pm 27,48 \mathrm{~b}$ & $304,00 \pm 4,15 \mathrm{c}$ & $75,52 \pm 0,34 \mathrm{~d}$ \\
\hline
\end{tabular}

* Médias seguidas da mesma letra não diferem pelo teste de Tukey, a 5\% de probabilidade de erro.

Os ensaios com adição de fumarato a composição nutricional, obtiveram as maiores eficiências de remoção de DQO $(85,07 \pm 0,38 \%)$ e até mesmo com a adição do 4-NF $(75,52 \pm 0,34 \%)$. A adição de Fumarato favorece a degradação de compostos aromáticos por meio da formação de benzilsuccinato (HEIDER, 2007; FUCHS; BOLL; HEIDER, 2011). A síntese de benzilsuccinato foi proposta a partir de tolueno (SEYFRIED et al., 1994) e posteriormente verificada para benzeno, xileno, etilbenzeno e compostos aromáticos de baixa massa molar (SCHMITT et al., 1996). A geração de benzilsuccinato é iniciada pela remoção de um átomo de hidrogênio do grupo metil, gerando um radical benzila ligado à enzima (glycylradical), que então poderia adicionar à ligação dupla de um substrato de fumarato no seu sítio 
ativo. O radical benzilsuccinil gerado se rearranja ao átomo de hidrogênio da enzima(glycylradical), produzindo (R)-benzilsuccinato e a enzima na forma de radical ativo (HEIDER et al., 1999).

Os ensaios com adição de metanol apresentaram as menores eficiências de remoção de de DQO, tanto para a condição controle $(77,75 \pm 0,91 \%)$ quanto no ensaio Metanol+4-NF $(60,39 \pm 1,00 \%)$. A adição de 4-NF ao meio reacional provocou redução significativa da eficiência de remoção de DQO para todos os co-substratos testados (Etanol, Metanol e Fumarato). Nas condições experimentais deste estudo, a composição nutricional com adição de Fumarato (600 $\left.\mathrm{mg} \mathrm{L}^{-1}\right)$ apresentou a maior eficiênicia de remoção de DQO $(85,07 \pm 0,38 \%)$ e, consequentemente, a menor concentração de DQO final $\left(170,00 \pm 2,45 \mathrm{mg} \mathrm{L}^{-1}\right)$, as quais foram estatisticamente diferentes das demais condições avaliadas, indicando o potencial de uso do Fumarato como co-substrato em reatores anaeróbios.

\subsection{2 pH e Alcalinidade}

Os valores de $\mathrm{pH}$ inicial variaram de 7,7 a 8,0 para os ensaios com Fumarato $+4-\mathrm{NF}$ e Etanol + 4-NF, respectivamente. Foram verificados valores de Alcalinidade Total de 196,73 mg CaCO $3 \mathrm{~L}^{-1}$ (Etanol), 197,45 $\mathrm{mg} \mathrm{CaCO}_{3} \mathrm{~L}^{-1}$ (Metanol) e 258,48 $\mathrm{mg} \mathrm{CaCO}_{3} \mathrm{~L}^{-1}$ (Fumarato) para os ensaios controle e 124,21 mg CaCO $3 \mathrm{~L}^{-1}$ (Etanol+4-NF), 125,65 mg $\mathrm{CaCO}_{3} \mathrm{~L}^{-1}$ (Metanol+4-NF) e 271,40 mg $\mathrm{CaCO}_{3} \mathrm{~L}^{-1}$ (Fumarato+4-NF) para os ensaios com adição de 4NF. O maior valor de Alcalinidade Total $\left(271,40 \mathrm{mg} \mathrm{CaCO}_{3} \mathrm{~L}^{-1}\right)$ foi verificado para o ensaio com Fumarato+4-NF, enquanto o menor valor $\left(124,21 \mathrm{mg} \mathrm{CaCO}_{3} \mathrm{~L}^{-1}\right)$ para o ensaio Etanol + 4-NF.

A adição de 4-NF ocasionou redução da Alcalinidade Total, Parcial e Intermediária nos ensaios Etanol+4-NF e Metanol+4-NF. Já para o ensaio Fumarato+4-NF verificou-se o aumento da Alcalinidade Total, Parcial e Intermediária. Os valores iniciais observados de $\mathrm{pH}$, Alcalinidade Parcial, Intermediária e Total e a relação AI/AP podem ser observados Tabela 5.8. 
Tabela 5.8 - Valores iniciais de pH, Alcalinidade Parcial, Intermediária e Total e Relação AI/AP.

\begin{tabular}{lccccc}
\hline \multirow{2}{*}{ Ensaios } & $\mathrm{pH}$ & \multicolumn{2}{c}{ Alcalinidade $\left(\mathrm{mg} \mathrm{CaCO}_{3} \mathrm{~L}^{-1}\right)$} & \multirow{2}{*}{ AI/AP } \\
\cline { 3 - 5 } & & $\mathrm{AP}$ & $\mathrm{AI}$ & $\mathrm{AT}$ & \\
\hline Etanol & 7,79 & 147,91 & 48,82 & 196,73 & 0,33 \\
Etanol + 4-NF & 8,00 & 96,21 & 28,00 & 124,21 & 0,29 \\
Metanol & 7,83 & 147,19 & 50,26 & 197,45 & 0,34 \\
Metanol + 4-NF & 7,93 & 94,78 & 30,87 & 125,65 & 0,33 \\
Fumarato & 7,79 & 145,75 & 112,73 & 258,48 & 0,77 \\
Fumarato + 4-NF & 7,75 & 155,09 & 116,32 & 271,40 & 0,75 \\
\hline
\end{tabular}

A adição de Fumarato a composição nutricional provocou aumento da Alcalinidade Intermediária e, consequentemente, aumento da relação AI/AP, tanto para o ensaio controle (Fumarato, AI/AP = 0,77) e com adição de 4-NF (Fumarato+4-NF, AI/AP = 0,75), em comparação aos valores verificados para os demais ensaios, que variaram de 0,29 a 0,34 para os ensaios Etanol+4-NF e Metanol, respectivamente.

Com relação aos valores de $\mathrm{pH}$ ao final dos ensaios, foi verificada variação de 7,28 a 7,61 para os ensaios Etanol e Metanol+4-NF, respectivamente. Foram verificados valores de Alcalinidade Total de 511,93 mg CaCO $\mathrm{LL}^{-1}$ (Etanol), 508,34 $\mathrm{mg} \mathrm{CaCO}_{3} \mathrm{~L}^{-1}$ (Metanol) e 756,05 $\mathrm{mg} \mathrm{CaCO} \mathrm{L}^{-1}$ (Fumarato) para os ensaios controle e 592,35 mg $\mathrm{CaCO}_{3} \mathrm{~L}^{-1}$ (Etanol+4-NF), $579,43 \mathrm{mg} \mathrm{CaCO} 3 \mathrm{~L}^{-1}$ (Metanol+4-NF) e 883,86 $\mathrm{mg} \mathrm{CaCO}_{3} \mathrm{~L}^{-1}$ (Fumarato+4-NF) para os ensaios com adição de 4-NF. O maior valor de Alcalinidade Total $\left(883,86 \mathrm{mg} \mathrm{CaCO}_{3} \mathrm{~L}^{-1}\right)$ foi verificado para o ensaio com Fumarato+4-NF, enquanto o menor valor $\left(508,34 \mathrm{mg} \mathrm{CaCO}_{3} \mathrm{~L}^{-1}\right)$ para o ensaio Metanol.

A adição de 4-NF ao meio reacional provocou aumento da Alcalinidade Parcial, Intermediária e Total para todas as condições nutricionais testadas. Para os valores de AI/AP, a adição de 4-NF provocou aumento na relação para os ensaios Etanol+4-NF (AI/AP = 0,36) e Metanol+4-NF (AI/AP = 0,39), em comparação aos seus respectivos ensaios controle Etanol $(\mathrm{AI} / \mathrm{AP}=0,32)$ e Metanol $(\mathrm{AI} / \mathrm{AP}=0,25) . \mathrm{O}$ mesmo comportamento não foi verificado em ensaios com adição de Fumarato; foram verificados valores AI/AP de 0,26 para os ensaios Fumarato e Fumarato+4-NF, indicando que a adição de 4-NF não promoveu a alteração da 
proporção entre alcalinidade intermediária e parcial. Os valores de $\mathrm{pH}$, Alcalinidade Parcial, Intermediária e Total e a relação AI/AP observados ao final dos ensaios em batelada podem ser verificados na Tabela 5.9.

Tabela 5.9 - Valores finais de pH, Alcalinidade Parcial, Intermediária e Total e Relação $\mathrm{AI} / \mathrm{AP}$.

\begin{tabular}{lccccc}
\hline \multirow{2}{*}{\multicolumn{1}{c}{ Ensaios }} & $\mathrm{pH}$ & \multicolumn{3}{c}{ Alcalinidade $\left(\mathrm{mg} \mathrm{CaCO}_{3} \mathrm{~L}^{-1}\right)$} & \multirow{2}{*}{ AI/AP } \\
\cline { 3 - 5 } & & $\mathrm{AP}$ & $\mathrm{AI}$ & $\mathrm{AT}$ & \\
\hline Etanol & 7,28 & 387,72 & 124,21 & 511,93 & 0,32 \\
Etanol + 4-NF & 7,52 & 435,83 & 156,52 & 592,35 & 0,36 \\
Metanol & 7,41 & 405,67 & 102,67 & 508,34 & 0,25 \\
Metanol + 4-NF & 7,61 & 416,44 & 162,99 & 579,43 & 0,39 \\
Fumarato & 7,50 & 599,53 & 156,52 & 756,05 & 0,26 \\
Fumarato + 4-NF & 7,50 & 701,49 & 182,37 & 883,86 & 0,26 \\
\hline
\end{tabular}

AP: Alcalinidade Parcial

AI: Alcalinidade Intermediária

AT: Alcalinidade Total

Foram verificados os maiores valores de Alcalinidade Parcial (701,49 $\left.\mathrm{mg} \mathrm{CaCO}_{3} \mathrm{~L}^{-1}\right)$, Intermediária $\left(182,37 \mathrm{mg} \mathrm{CaCO}_{3} \mathrm{~L}^{-1}\right)$ e Total $\left(883,86 \mathrm{mg} \mathrm{CaCO}_{3} \mathrm{~L}^{-1}\right)$ para o ensaio Fumarato+4-NF, em comparação aos demais ensaios com adição de 4-NF (Etanol+4-NF e Metanol+4-NF). Este comportamento pode estar relacionado a maior eficiência de remoção de DQO verificada no ensaio Fumarato+4-NF $(75,52 \pm 0,34 \%)$ e consequente tamponamento do meio reacional proporcionado pelo $\mathrm{CO}_{2}$ produzido.

\subsubsection{Remoção de 4-Nonilfenol}

Em relação as eficiências de remoção de 4-NF, não foi verificada diferença significativa

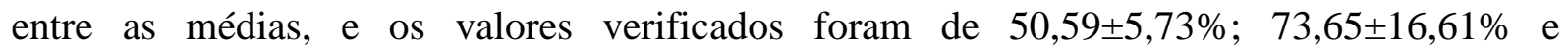
$81,44 \pm 14,25 \%$ para os ensaios com Fumarato+4-NF, Metanol+4-NF e Etanol+4-NF, respectivamente. As concentrações médias de 4-NF inicial, final e eficiências de remoção podem ser observadas Tabela 5.10. 
Tabela 5.10 - Valores médios de 4-NF Inicial, Final e Eficiência de Remoção

\begin{tabular}{|c|c|c|c|}
\hline \multirow{2}{*}{ Ensaios } & \multicolumn{2}{|c|}{ Nonilfenol $\left(\mu \mathrm{g} \mathrm{L}^{-1}\right)$} & \multirow{2}{*}{ Eficiência (\%) } \\
\hline & Inicial & Final & \\
\hline Etanol+4-NF & $288,97 \pm 96,49$ a & $52,86 \pm 41,91 \mathrm{~b}$ & $81,44 \pm 14,25 \mathrm{a}$ \\
\hline Metanol+4-NF & $469,98 \pm 182,42 \mathrm{a}^{*}$ & $110,95 \pm 50,37 \mathrm{~b}$ & $73,65 \pm 16,61$ a \\
\hline Fumarato+4-NF & $435,76 \pm 70,38 \mathrm{a}$ & $212,61 \pm 9,26 \mathrm{a}$ & $50,59 \pm 5,73 \mathrm{a}$ \\
\hline
\end{tabular}

* Médias seguidas da mesma letra não diferem pelo teste de Tukey, a 5 e $10 \%$ de probabilidade de erro.

As eficiências de remoção de 4-NF não apresentarem diferença estatística pelo teste de Tukey a 5\% e 10\% de probabilidade de erro, devido ao alto desvio padrão entre as réplicas. Entretanto, a maior eficiência média foi verificada para o ensaio com Etanol+4-NF. Isto pode estar relacionado a concentração inicial de 4-NF neste ensaio $\left(288,97 \pm 96,49 \mu \mathrm{g} \mathrm{L}^{-1}\right)$, a qual foi a menor em comparação aos ensaios com Metanol + 4-NF $\left(469,98 \pm 182,42 \mu \mathrm{g} \mathrm{L}^{-1}\right)$ e Fumarato + 4-NF $\left(435,76 \pm 70,38 \mu \mathrm{g} \mathrm{L}^{-1}\right)$. A maior concentração final de 4-NF foi verificada para o ensaio Fumarato+4-NF $\left(212,61 \pm 9,26 \mu \mathrm{g} \mathrm{L}^{-1}\right)$, seguido de Metanol+4-NF $\left(110,95 \pm 50,37 \mu \mathrm{g} \mathrm{L}^{-1}\right) \mathrm{e}$ Etanol+4-NF $\left(52,86 \pm 41,91 \mu \mathrm{g} \mathrm{L}^{-1}\right)$.

Os elevados desvios padrão verificados para a concentração de 4-NF inicial, final e eficiência de remoção da Tabela 5.10 podem estar relacionados ao fenômeno de adsorção ao lodo. Devido ao seu caráter hidrofóbico, o 4-NF tende a adsorver no lodo de estação de tratamento de esgoto (AHEL et al., 1994; PETROVIC et al., 2002b; LEE et al., 2013; GORGA et al., 2015; WANG et al., 2016; PENG et al., 2017) atingindo concentração muito superior as verificadas na fase líquida, o que pode ter ocorrido nestes testes com reatores em batelada.

Peng et al. (2017) monitoraram a ocorrênica de contaminantes emergentes em seis rios urbanos da cidade de Guangzhou (China) e verificaram que o 4-NF foi o mais recorrente ${ }^{14}$, com concentrações máximas de 5,05 $\mu \mathrm{g} \mathrm{L}^{-1}$ para a fase líquida e $14,40 \mu \mathrm{g} \mathrm{g}^{-1}$ de sedimento seco. Lee et al. (2013) avaliaram os parâmetros de qualidade da água e ocorrência de 4-NF nos 16 maiores

\footnotetext{
${ }^{14}$ Peng et al. (2017) monitoraram, além de 4-Nonilfenol, um total de vinte compostos, incluindo: 4-tert- octifenol (4-t-OP), bisfenol A (BPA), triclocarban (TCC), triclosan (TCS), galaxolide (HHCB) e tonalide (AHTN), musk xyleno (MX), musk ketone (MK), ácido clofibrico, ketoprofeno, naproxeno, diclofenaco, indometacina, ibuprofeno, ácido meclofenamico, ácid mefenamico, fenoprofeno, gemfibrozil e ácido tolfenamico.
} 
rios ${ }^{15}$ de Taiwan (China), em zonas com lançamento de efluentes e verificaram concentrações máximas de 3,94 $\mu \mathrm{g} \mathrm{L}^{-1}$ para amostras de água e 47,79 $\mu \mathrm{g} \mathrm{g}^{-1}$ de sedimento seco.

Deste modo, foi verificada a remoção anaeróbia de 4-NF nas condições experimentais testadas no presente estudo. Entretanto, não foi possível inferir o melhor co-substrato para promover a biodegradação deste composto, devido a diferença de concentração inicial e pela elevada afinidade de adsorção no 4-NF na matriz orgânica do reator. Neste estudo não foi avaliada a fração adsorvida ao lodo dos reatores em batelada, a qual pode desempenhar grande papel na adsorção de 4-NF, de acordo com os estudos supracitados.

\subsubsection{Potêncial metanogênico - Produção de $\mathrm{CH}_{4}$ e Parâmetros cinéticos}

Os valores médios de produção acumulada de metano foram de 2.292,34 $\mu$ mol para os ensaios controle (Etanol, Metanol e Fumarato) e 2.744,74 $\mu$ mol para ensaios com adição de 4-

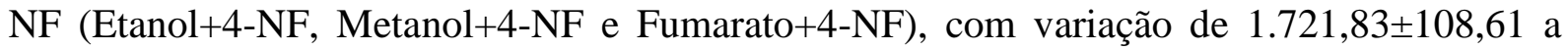
$3.163,68 \pm 169,17 \mu \mathrm{mol}$ para os ensaios Metanol e Fumarato+4-NF, respectivamente. A velocidade média de produção de metano foi de $24,5 \mu \mathrm{mol} \mathrm{h}^{-1}$ para os ensaios controle (Etanol, Metanol e Fumarato) e 10,9 $\mu \mathrm{mol} \mathrm{h}^{-1}$ para ensaios com adição de 4-NF (Etanol+4-NF, Metanol+4-NF e Fumarato+4-NF). Os parâmetros cinéticos obtidos com base na curva de produção acumulada de metano em todos os ensaios em batelada podem ser verificados na Tabela 5.11.

Tabela 5.11 - Parâmetros cinéticos para todos os ensaios em reatores em batelada.

\begin{tabular}{lcccc}
\hline \multicolumn{1}{c}{ Ensaios } & $\begin{array}{c}\text { Produção } \\
\text { acumulada }(\mu \mathrm{mol})\end{array}$ & $\begin{array}{c}\text { Velocidade de } \\
\text { produção }\left(\mu \mathrm{mol} \mathrm{d}{ }^{-1}\right)\end{array}$ & $\begin{array}{c}\text { Tempo de } \\
\text { início }(\mathrm{h})\end{array}$ & $\mathrm{R}^{2}$ \\
\hline Etanol & $2.849,39 \pm 107,36$ & $26,69 \pm 2,71$ & $17,40 \pm 5,02$ & 0,9839 \\
Etanol+4-NF & $2.883,48 \pm 180,94$ & $11,50 \pm 1,07$ & $122,00 \pm 10,26$ & 0,9896 \\
Metanol & $1.721,83 \pm 108,61$ & $16,71 \pm 3,00$ & $11,04 \pm 8,78$ & 0,9464 \\
Metanol+4-NF & $2.187,06 \pm 57,76$ & $9,53 \pm 0,49$ & $112,31 \pm 5,60$ & 0,9960 \\
Fumarato & $2.305,80 \pm 85,02$ & $29,92 \pm 4,77$ & $19,12 \pm 5,46$ & 0,9715 \\
Fumarato+4-NF & $3.163,68 \pm 169,17$ & $11,75 \pm 0,68$ & $89,40 \pm 6,80$ & 0,9908 \\
\hline
\end{tabular}

\footnotetext{
${ }^{15}$ Os 16 rios monitorados por Lee et al. (2013) foram: Siouguluan; Dahan; Sindian; Keelung; Danshuei; Laojie; Toucian; Koya; Dajia; Jhuoshuei; Hsinhuwei; Beigang; Puzih; Jiangchun; Erren e Love River.
} 
O 4-NF elevou a produção de metano com a utilização para os co-substratos Fumarato

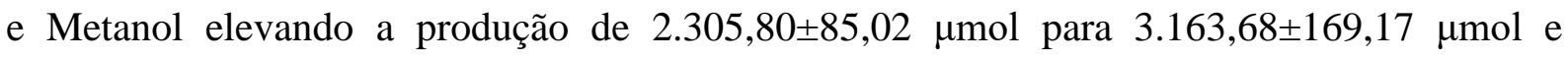
$1.721,83 \pm 108,61 \mu \mathrm{mol}$ para $2.187,06 \pm 57,76 \mu \mathrm{mol}$, respectivamente, ou seja, um aumento de $37,2 \%$ para o Fumarato e 27\% para o Metanol, auxiliando na conversão do substrato a metano. Os valores de produção de metano para os reatores com Etanol não foram significativos, como observados na Tabela 5.11.

Entretanto, a adição de 4-NF a composição nutricional dos reatores em batelada provocou redução da velocidade de produção de $\mathrm{CH}_{4}$, independentemente do co-subtrato usado, com o menor valor $\left(9,53 \pm 0,49 \mu \mathrm{mol} \mathrm{h}^{-1}\right)$ verificado para o ensaio Metanol+4-NF. A redução percentual da velocidade de produção de $\mathrm{CH}_{4}$ foi de 57\%, 43\% e 61\% para Etanol+4-NF, Metanol+4-NF e Fumarato+4-NF, respectivamente, em comparação aos ensaios controle (Etanol, Metanol e Fumarato).

Também foi verificado o aumento do tempo de início de produção de $\mathrm{CH}_{4}$ após adição

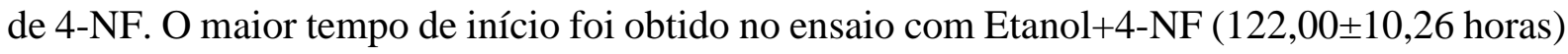

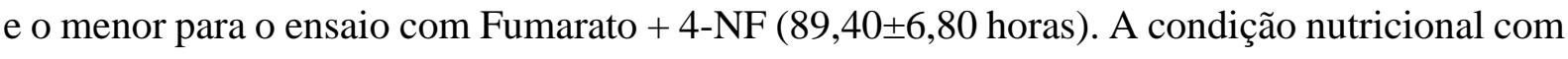
adição de fumarato e 4-Nonilfenol (Fumarato+4-NF) também apresentou a maior velocidade de produção $\left(11,75 \pm 0,68 \mu \mathrm{mol} \mathrm{h}^{-1}\right)$ e produção acumulada de metano $(3.163,68 \pm 169,17 \mu \mathrm{mol})$. Provavelmente, a adição de fumarato pode ter favorecido a degradação e conversão do 4-NF a substratos para a produção de metano. A degradação de compostos aromáticos pode ser favorecida pela adição de fumarato, formando benzilsuccinato, como descrito por Heider (2007); Fuchs; Boll e Heider (2011).

Além da atuação do fumarato no metabolismo de degradação de compostos aromáticos, Stams (1994) também relatou ação do fumarato no metabolismo de oxidação do propionato, no qual os microrganismos foram capazes de acoplar a degradação do propionato a redução do fumarato, gerando succinato. A proporção gerada foi de 1 mol de acetato e 3 mol de succinato para cada $1 \mathrm{~mol}$ de propionato e $3 \mathrm{~mol}$ de fumarato consumidos. Microrganismos do gênero Methanosaeta são os principais produtores de metano em consórcios anaeróbios (SMITH; INGRAM-SMITH, 2007) e utilizam unicamente acetato como substrato (SPEECE, 1983; STAMS, 1994). Assim, a adição de fumarato aos ensaios em batelada pode ter favorecido a produção de acetato e, consequentemente, a produção de metano por arqueias metanogênicas acetoclásticas.

A adição de 4-NF (Etanol+4-NF, Metanol+4-NF e Fumarato+4-NF) ocasionou aumento no tempo de adaptação da biomassa e retardou a velocidade de conversão de substrato em 
metano em todas as condições experimentais deste estudo. A produção de $\mathrm{CH}_{4}$ acumulada e o ajuste ao modelo de Gompertz modificado podem ser visualizados na Figura 5.11.

Figura 5.11 - Produção acumulada de metano e ajuste ao modelo de Gompertz modificado nos ensaios controle e com adição de 4-Nonilfenol.

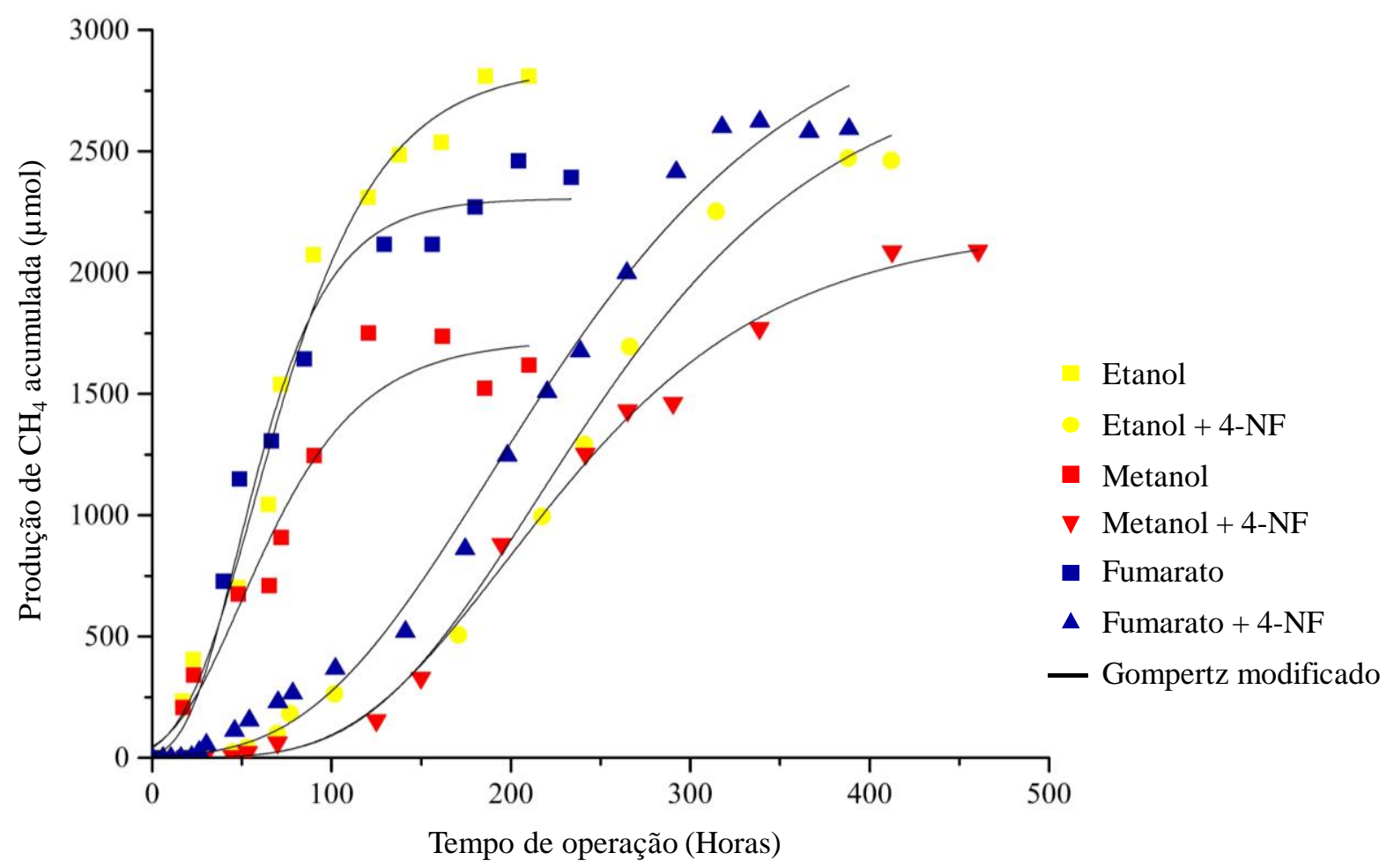

Fonte: $\mathrm{O}$ autor.

Motteran et al. (2014b) avaliaram o potencial metanogênico em reatores em batelada com adição de surfactante aniônico (LAS) e não iônico (LAE), utilizando meio de cultura ${ }^{16}$; a eficiência máxima de remoção de DQO foi 79,4ะ16\% para uma concentração inicial de LAE de $24,1 \pm 0,7 \mathrm{mg} \mathrm{L}^{-1}$ e $86,2 \pm 2,8 \%$ para uma concentração inicial de LAS de 75,4 \pm 7,5 $\mathrm{mg} \mathrm{L}^{-1}$, e verificaram que a adição de surfactante favoreceu um aumento de $26 \%$ da produção acumulada $(783,3 \pm 20,6 \mu \mathrm{mol})$ para LAE e $27 \%$ de aumento na produção acumulada $(1.141,8 \pm 65,5 \mu \mathrm{mol})$ em ensaio com adição de LAS; entretanto, houve redução da velocidade de produção $(28,1 \pm 4,9$ $\mu \mathrm{mol} \mathrm{d} \mathrm{d}^{-1}$ para LAE e $8,16 \pm 1,71 \mu \mathrm{mol} \mathrm{d} \mathrm{d}^{-1}$ para LAS), comportamento similar ao verificado no presente estudo.

\footnotetext{
${ }^{16} \mathrm{O}$ meio de cultura usado por Motteran et al. (2014b), em concentrações para um volume reacional de $250 \mathrm{~mL}$, consistiu em: extrato de levedura $(0,11 \mathrm{~g})$, sacarose $(0,018 \mathrm{~g})$, bicarbonato de sódio $(0,09 \mathrm{~g})$ e $1,125 \mathrm{~mL}$ de solução salina ( $\left.\mathrm{NaCl} 50 \mathrm{~g} \mathrm{~L}^{-1}, \mathrm{MgCl}_{2} 1,4 \mathrm{~g} \mathrm{~L}^{-1}, \mathrm{CaCl}_{2} 0,9 \mathrm{~g} \mathrm{~L}^{-1}\right)$.
} 
Para Doorn et al. (2006) o principal fator para estimar o potencial de geração de metano de um substrato é a partir da concentração de matéria orgânica, geralmente expressa em DQO. Conhecendo-se a concentração de matéria orgânica (DQO), pode-se estimar a produção teórica de metano, no qual toda a matéria orgânica biodegradável seria convertida em biogás; atingindo uma concentração de $0,25 \mathrm{~kg} \mathrm{CH}_{4} \mathrm{~kg}^{-1}$ DQO.

Assim, com base no conceito de produção teórica de metano, neste estudo foram verificados valores de $13.767,66 \mu \mathrm{mol}$ a 20.342,89 $\mu \mathrm{mol}$ para os ensaios Metanol e Etanol+4$\mathrm{NF}$, respectivamente. $\mathrm{O}$ maior percentual de conversão de produção de $\mathrm{CH}_{4}$ observada com relação Produção Teórica foi para o ensaio Fumarato+4-NF (16,3\%), enquanto o menor percentual para o ensaio Metanol (12,5\%). Os valores de produção teórica de $\mathrm{CH}_{4}$, produção observada e percentual de conversão podem ser verificados na Tabela 5.12.

Tabela 5.12 - Valores de produção teórica de $\mathrm{CH}_{4}$, produção observada e percentual de conversão.

\begin{tabular}{lcccc}
\hline \multicolumn{1}{c}{ Ensaio } & $\begin{array}{c}\text { DQO inicial } \\
\left(\mathrm{mg} \mathrm{L}^{-1}\right)\end{array}$ & $\begin{array}{c}\text { Produção teórica } \\
(\mu \mathrm{mol})\end{array}$ & $\begin{array}{c}\text { Produção } \\
\text { Observada }(\mu \mathrm{mol})\end{array}$ & $\begin{array}{c}\text { Conversão } \\
(\%)\end{array}$ \\
\hline Etanol & $1.183,33$ & $18.443,47$ & $2.849,39$ & 15,4 \\
Etanol+4-NF & $1.305,20$ & $20.342,89$ & $2.883,48$ & 14,2 \\
Metanol & 883,33 & $13.767,66$ & $1.721,83$ & 12,5 \\
Metanol+4-NF & 914,83 & $14.258,62$ & $2.187,06$ & 15,3 \\
Fumarato & $1.160,83$ & $18.092,79$ & $2.305,80$ & 12,7 \\
Fumarato+4-NF & $1.242,00$ & $19.357,86$ & $3.163,68$ & 16,3 \\
\hline
\end{tabular}

Com base nos valores de produção teórica de $\mathrm{CH}_{4}$ da Tabela 5.12, é possível verificar que a adição de 4-NF aumentou o percentual de metano produzido em relação ao valor teórico para os ensaios Metanol+4-NF (de 12,5\% para 15,3\%) e Fumarato+4-NF (de 12,7\% para $16,3 \%$ ), diferentemente do ensaio Etanol+4-NF, onde foi verificada a redução do percentual de $15,4 \%$ para $14,2 \%$.

De acordo com os valores calculados para produção teórica de $\mathrm{CH}_{4}$, a hierarquia de produção (do maior para o menor) para os ensaios controle (Etanol, Metanol e Fumarato) foi Etanol > Fumarato > Metanol. Para os ensaios com adição de 4-NF (Etanol+4-NF, Metanol+4-NF e Fumarato+4-NF) foi verificado o mesmo comportamento. 
Para os valores de produção de $\mathrm{CH}_{4}$ observada, a hierarquia de produção para os ensaios controle (Etanol, Metanol e Fumarato) foi Etanol > Fumarato > Metanol, seguindo o mesmo comportamento dos valores teóricos. Entretanto, para os ensaios com adição de 4-NF (Etanol+4-NF, Metanol+4-NF e Fumarato+4-NF) não foi verificado o mesmo desempenho e a hierarquia de produção foi Fumarato+4-NF > Etanol+4-NF > Metanol+4-NF, indicativo da presença de 4-NF alterou a hierarquia de desempenho. A comparação entre os valores de produção teórica de metano, produção observada e percentual de conversão para todos os ensaios em reatores em batelada pode ser verificada na Figura 5.12.

Figura 5.12 - Comparação entre Produção de Metano acumulada, Produção Teórica e percentual de conversão para todos os ensaios em reatores em batelada.

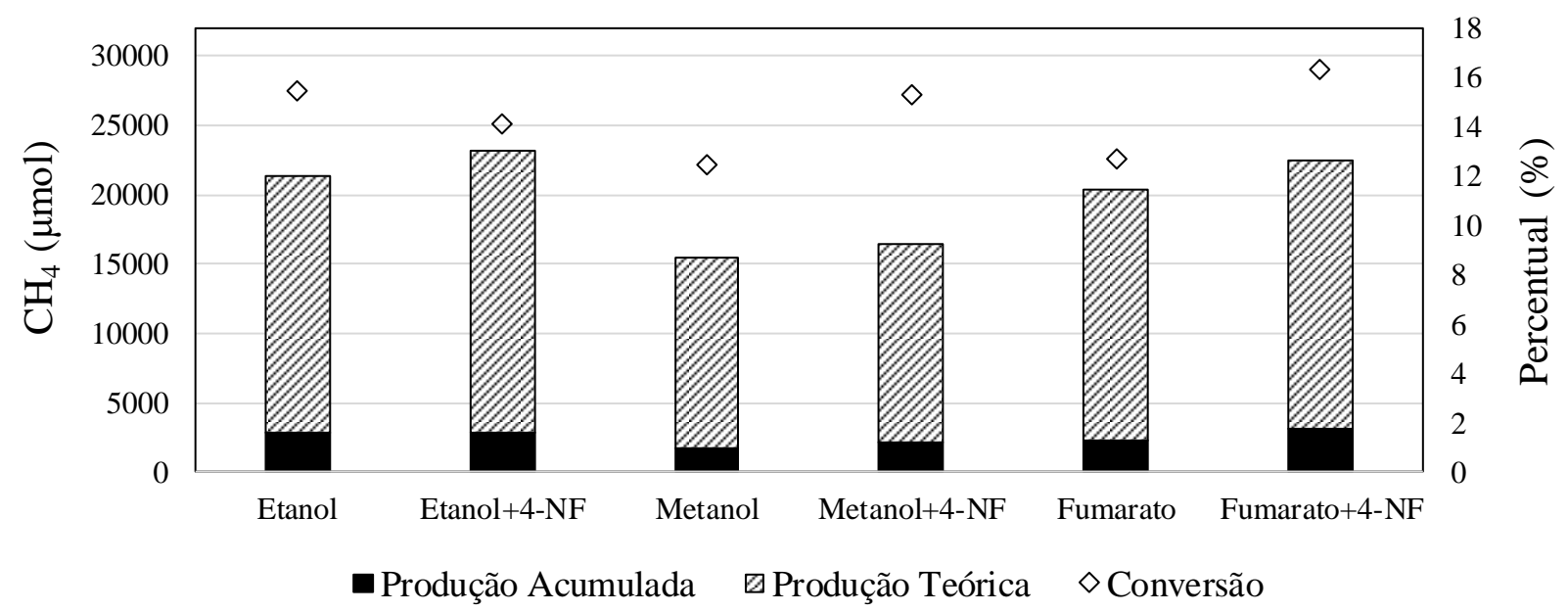

Fonte: $\mathrm{O}$ autor.

Por meio da análise da Figura 5.12 é possível verificar que a produção acumulada de metano que mais se aproximou do valor teórico foi para o ensaio Fumarato+4-NF com adição de $600 \mathrm{mg} \mathrm{L}^{-1}$ de Fumarato e 435,76 $\pm 70,38 \mu \mathrm{g} \mathrm{L}^{-1}$ de 4-NF, atingindo 16,3\% da produção teórica de $\mathrm{CH}_{4}$.

$\mathrm{O}$ maior percentual de produção de $\mathrm{CH}_{4}$ verificado no ensaio Fumarato+4-NF pode estar relacionado à rota metabólica de degradação, uma vez que a adição de fumarato favorece a síntese de benzilsuccinato em condições anaeróbias estritas (EVANS et al., 1992; SEYFRIED et al., 1994; SCHMITT et al., 1996; HEIDER et al., 1999), catalisando a degradação de compostos aromáticos (HEIDER, 2007; FUCHS; BOLL; HEIDER, 2011) e, consequentemente, aumentando a produção de metano. 


\subsubsection{Eletroforese em Gel com Gradiente Desnaturante (DGGE)}

Foram analisadas amostras da biomassa de todos os ensaios em reatores em batelada e, pela análise do perfil de bandas do DGGE, foram observadas mudanças nas populações microbianas para os Domínios Archaea e Bacteria.

\subsubsection{Domínio Bacteria}

Mediante comparação do perfil de bandas para o domínio Bacteria observou-se similaridade de $40 \%$ do inóculo com os demais ensaios, indicando que todas as condições experimentais testadas promoveram grande alteração da comunidade microbiana para o domínio Bacteria. Os maiores percentuais de similaridade foram verificados para os ensaios Fumarato e Fumarato+4-NF (96\%), e Etanol e Metanol (96\%). A elevada similaridade (96\%) entre os ensaios com adição de Fumarato (Fumarato e Fumarato+4-NF) indica que para este cosubstratos a adição de 4-NF provocou pouca alteração na comunidade microbiana. Os percentuais de similaridade para o domínio Bacteria para os ensaios em reatores em batelada podem ser verificados no dendograma da Figura 5.13.

Figura 5.13 - Análise de cluster (Correlação de Pearson, UPGMA) do perfil das bandas do DGGE dos fragmentos do RNAr 16S para o Domínio Bacteria.
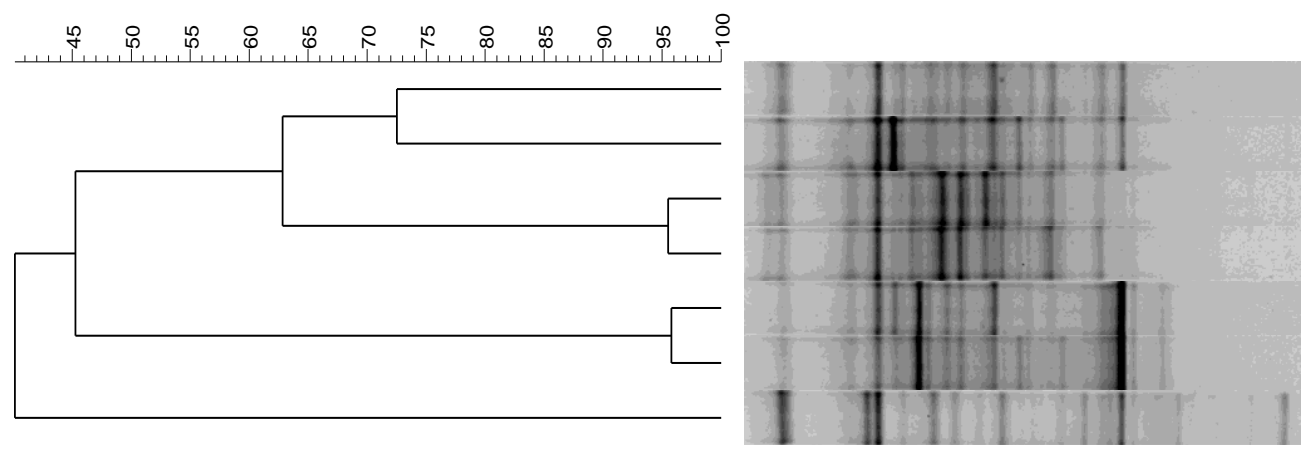

Etanol + NF
Metanol + NF
Fumarato
Fumarato + NF
Etanol
Metanol
Inóculo

Fonte: $\mathrm{O}$ autor.

Os ensaios Etanol+4-NF e Metanol+4-NF apresentaram similaridade de 45\% com seus respectivos ensaios controle, Etanol e Metanol, indicando que a adição de 4-NF na presença 
destes co-substratos (Etanol e Metanol) provoca grandes alterações na composição da comunidade microbiana.

Em relação aos índices ecológicos para a o domínio Bacteria, os maiores valores de diversidade $(2,742)$ e riqueza (22) foram verificados para a amostra de inóculo. Para as amostras referentes aos ensaios em batelada, a maior diversidade ${ }^{17}$ (2,721) e riqueza (21) foram observadas para o ensaio Fumarato + 4-NF, enquanto que o ensaio Etanol apresentou os menores valores de diversidade $(2,421)$ e riqueza (16). Os valores referentes aos índices de diversidade para o Domínio Bacteria para os ensaios em reatores em batelada e Inóculo podem ser verificados na Tabela 5.13.

Tabela 5.13 - Índices de diversidade para o Domínio Bacteria em ensaios com reatores em batelada e inóculo.

\begin{tabular}{lccccccc}
\hline & \multicolumn{7}{c}{ Condição } \\
\cline { 2 - 8 } Indice & Inóculo & Etanol & $\begin{array}{c}\text { Etanol } \\
+4-N F\end{array}$ & Metanol & $\begin{array}{c}\text { Metanol } \\
+4-N F\end{array}$ & Fumarato & $\begin{array}{c}\text { Fumarato } \\
+ \text { 4-NF }\end{array}$ \\
\hline Dominância & 0,0821 & 0,111 & 0,084 & 0,099 & 0,087 & 0,085 & 0,082 \\
Diversidade & 2,742 & 2,421 & 2,642 & 2,610 & 2,663 & 2,673 & 2,721 \\
Equitabilidade & 0,887 & 0,873 & 0,9142 & 0,886 & 0,905 & 0,878 & 0,894 \\
Riqueza & 22 & 16 & 18 & 19 & 19 & 21 & 21 \\
\hline
\end{tabular}

Motteran et al. (2014b) avaliaram o potencial metanogênico de lodo anaeróbio na presença de surfactantes aniônico (LAS) e não iônico (LAE) em reatores em batelada; houve aumento no índice de diversidade para o domínio Bacteria de 3,5\% para o ensaio com adição de LAE e 3,8\% com adição de LAS, próximo aos valores encontrados no presente trabalho (aumento médio de 4,0\%).

Foi verificado aumento da diversidade para todos os ensaios com adição de 4-NF (Etanol+4-NF, Metanol+4-NF e Fumarato+4-NF), em comparação aos ensaios sem adição de 4-NF (Etanol, Metanol e Fumarato), conforme ilustrado na Figura 5.14.

\footnotetext{
${ }^{17} \mathrm{O}$ índice de Shannon é o mais usado no mundo (LUDWIG; REYNOLDS, 1988; BEISEL; MORETEAU, 1997) para estimar a diversidade de uma população, assim, quanto maior o número mais diversa a composição de uma comunidade (SHANNON; WEAVER, 1948).
} 
Figura 5.14 - Variação dos índices de riqueza e diversidade para o Domínio Bacteria em ensaios com reatores em batelada e inóculo.

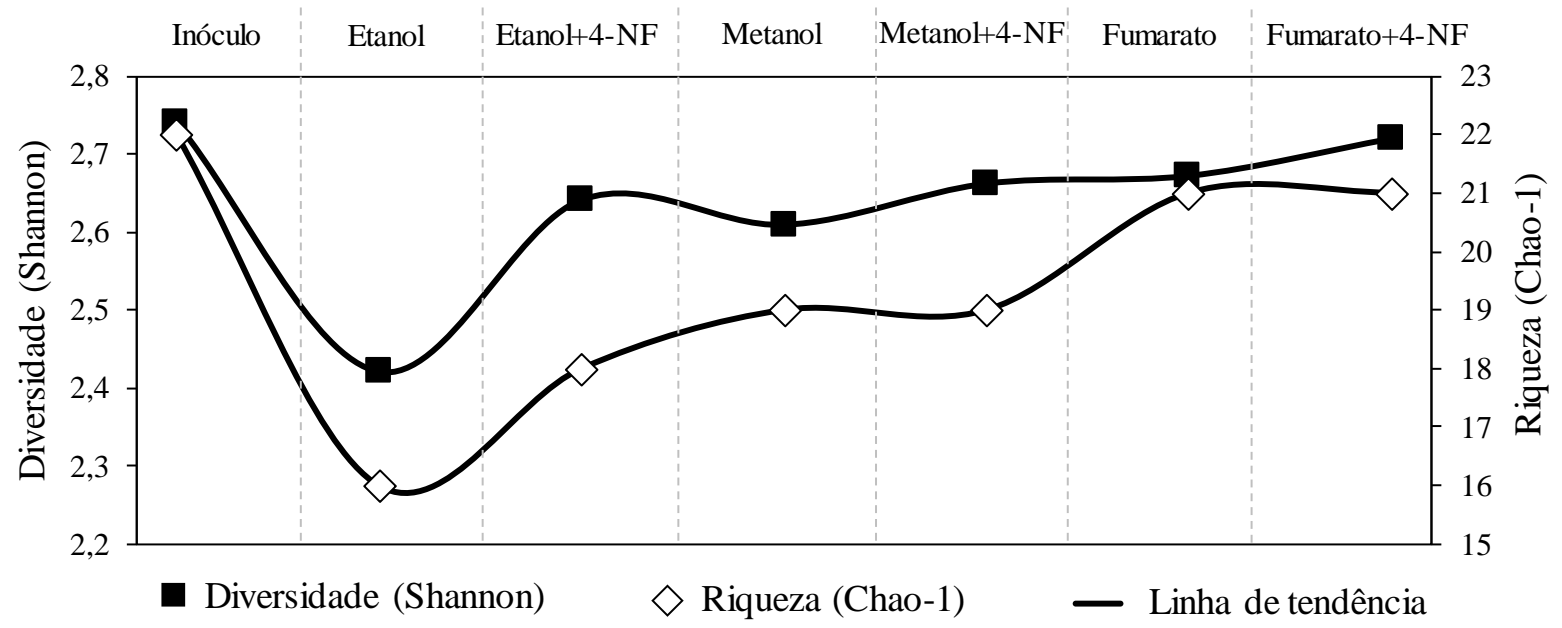

Fonte: $\mathrm{O}$ autor.

Os valores encontrados para o índice de equitabilidade variaram de 0,873 (Etanol) a 0,9142 (Etanol + 4-NF). Foi verificado aumento da equitabilidade para todos os ensaios com adição de 4-NF (Etanol+4-NF, Metanol+4-NF e Fumarato+4-NF) em relação aos ensaios controle (Etanol, Metanol e Fumarato).

Para os ensaios com adição de 4-NF ocorreu a redução da dominância ${ }^{18}$ para todos os co-substratos testados, em comparação aos ensaios sem adição de 4-NF; proporcionando também o aumento da equitabilidade ${ }^{19}$ (Pielou). Em todos os ensaios observou-se a redução do índice de dominância e, consequentemente, aumento da distribuição equitativa das comunidades, indicada pelo índice de equitabilidade de Pielou.

O aumento da diversidade em ensaios com adição de 4-NF (Etanol+4-NF, Metanol+4NF e Fumarato+4-NF) ocasionou a redução do índice de dominância em relação aos ensaios controle (Etanol, Metanol e Fumarato), conforme Figura 5.15.

\footnotetext{
${ }^{18}$ O índice de Simpson foi o primeiro usado em estudos ecológicos e indica a probabilidade de dois indivíduos, selecionados ao acaso na amostra, pertencerem à mesma espécie. Assim, 1-Simpson indica a dominância de uma ou mais espécies em uma comunidade, fazendo com que a Dominância represente um valor na escala de zero a um; quanto mais próximo de zero maior a Dominância e quanto mais próximo de 1, maior a distribuição equânime entre os táxons. (SIMPSON, 1949; LUDWIG; REYNOLDS, 1988)

19 O índice de Pielou representa a proporção da diversidade de espécies encontradas na amostragem atual em relação à diversidade máxima que a comunidade poderá atingir (PIELOU, 1966).
} 
Figura 5.15 - Variação dos índices de diversidade e dominância para o Domínio Bacteria em ensaios com reatores em batelada e inóculo.

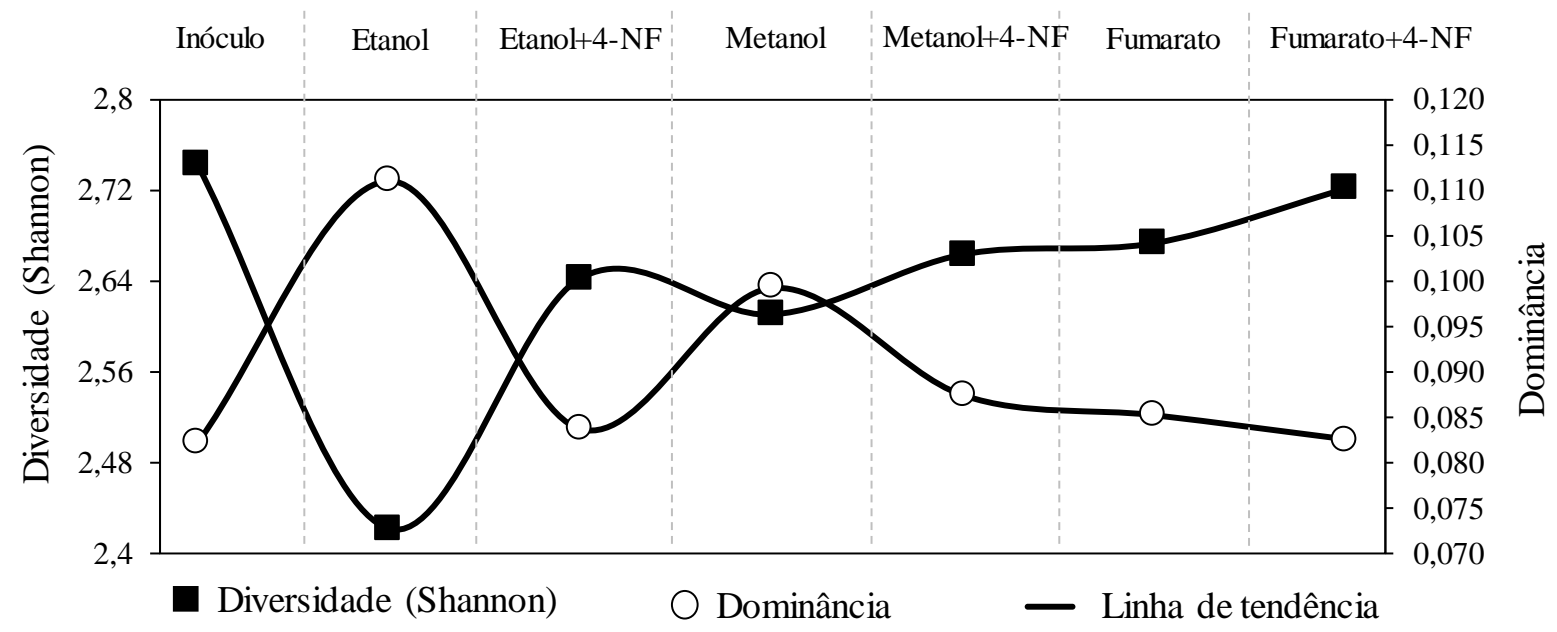

Fonte: $\mathrm{O}$ autor.

\subsubsection{Domínio Archaea}

Mediante comparação do perfil de bandas para o domínio Archaea observou-se similaridade de $82 \%$ do inóculo com os demais ensaios, indicando que as condições experimentais testadas provocaram alterações mais sutis na comunidade microbiana para o domínio Archaea em comparação ao domínio Bacteria (similaridade de 40\%). Os percentuais de similaridade foram de 98\% para Etanol e Etanol+4-NF, 96\% para Metanol e Metanol+4-NF e $91 \%$ para Fumarato e Fumarato+4-NF, indicando que a adição de 4-NF provocou pequenas alterações na comunidade microbiana para o domínio Archea e os ensaios com adição de 4-NF (Etanol+4-NF, Metanol+4-NF e Fumarato+4-NF) foram mais similares aos seus respectivos ensaios controle (Etanol, Metanol e Fumarato). Os percentuais de similaridade para o domínio Archaea para os ensaios em reatores em batelada podem ser verificados no dendograma da Figura 5.16. 
Figura 5.16 - Análise de cluster (Correlação de Pearson, UPGMA) do perfil das bandas do DGGE dos fragmentos do rRNA 16S para o Domínio Archaea.
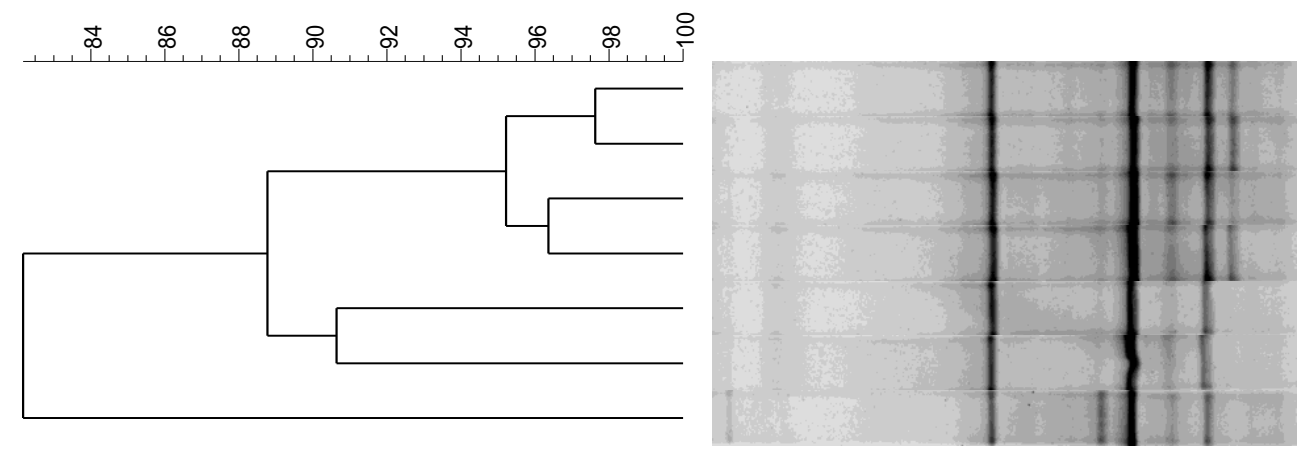

Etanol

Etanol + NF

Metanol

Metanol + NF

Fumarato

Fumarato + NF

Fonte: $\mathrm{O}$ autor.

Inóculo

Em todos as condições testadas houve maior similaridade entre ensaios com adição de 4-NF (Etanol + 4-NF, Metanol + 4-NF e Fumarato + 4-NF) e seu respectivo ensaio controle (Etanol, Metanol e Fumarato), indicando que o tipo de co-substrato causou maior efeito a comunidade do domínio Archaea do que a presença de 4-NF.

Em relação aos índices ecológicos para a o domínio Archaea, os maiores valores de diversidade $(2,048)$ e riqueza (12) foram verificados para a amostra de inóculo. Para as amostras referentes aos ensaios em batelada, a maior diversidade $(1,964)$ ocorreu para o ensaio Etanol+4$\mathrm{NF}$, enquanto que o ensaio Fumarato apresentou os menores valores de diversidade $(1,269)$ e riqueza (5). Verificou-se aumento da diversidade para todos os ensaios com adição de 4-NF (Etanol+4-NF, Metanol+4-NF e Fumarato+4-NF), em comparação aos ensaios sem adição de 4-NF (Etanol, Metanol e Fumarato). Os valores referentes aos índices de diversidade para o Domínio Archea para os ensaios em reatores em batelada e Inóculo podem ser verificados na Tabela 5.14.

Tabela 5.14 - Índices de diversidade para o Domínio Archaea em ensaios com reatores em batelada e Inóculo.

\begin{tabular}{lcccccccc}
\hline \multirow{1}{*}{ Índice } & \multicolumn{7}{c}{ Condição } \\
\cline { 2 - 8 } & Inóculo & Etanol & $\begin{array}{c}\text { Etanol } \\
+4-N F\end{array}$ & Metanol & $\begin{array}{c}\text { Metanol } \\
+4-N F\end{array}$ & Fumarato & $\begin{array}{c}\text { Fumarato } \\
+4-N F\end{array}$ \\
\hline Dominância & 0,1677 & 0,1794 & 0,1722 & 0,198 & 0,1788 & 0,318 & 0,2948 \\
Diversidade & 2,048 & 1,936 & 1,964 & 1,862 & 1,902 & 1,269 & 1,348 \\
Equitabilidade & 0,8241 & 0,8073 & 0,8192 & 0,7766 & 0,8258 & 0,7888 & 0,8374 \\
Riqueza & 12 & 11 & 11 & 11 & 10 & 5 & 5 \\
\hline
\end{tabular}


Não houve variação do índice de riqueza para os ensaios Etanol+4-NF e Fumarato+4NF, em relação aos ensaios controle (Metanol e Fumarato). Apenas para o ensaio Metanol+4NF ocorreu redução da riqueza (de 11 para 10) em relação ao ensaio sem adição de 4-NF (Metanol).

O índice de equitabilidade variou de 0,7766 (Metanol) a 0,8374 (Fumaratol+4-NF). Houve aumento da equitabilidade para todos os ensaios com adição de 4-NF (Etanol+4-NF, Metanol+4-NF e Fumarato+4-NF) em relação aos ensaios controle (Etanol, Metanol e Fumarato), os quais também estiveram próximos ao valor encontrado na amostra de inóculo $(0,8241)$.

Apenas para o ensaio Metanol+4-NF verificou-se redução do índice de riqueza (de 11 para 10), enquanto em Etanol+4-NF e Fumarato+4-NF não foi constatada alteração. A variação dos índices de diversidade e riqueza para o Domínio Bacteria pode ser observada na Figura 5.17 .

Figura 5.17 - Variação dos índices de diversidade e riqueza para o Domínio Archaea em ensaios com adição de 4-NF em reatores em batelada e inóculo.

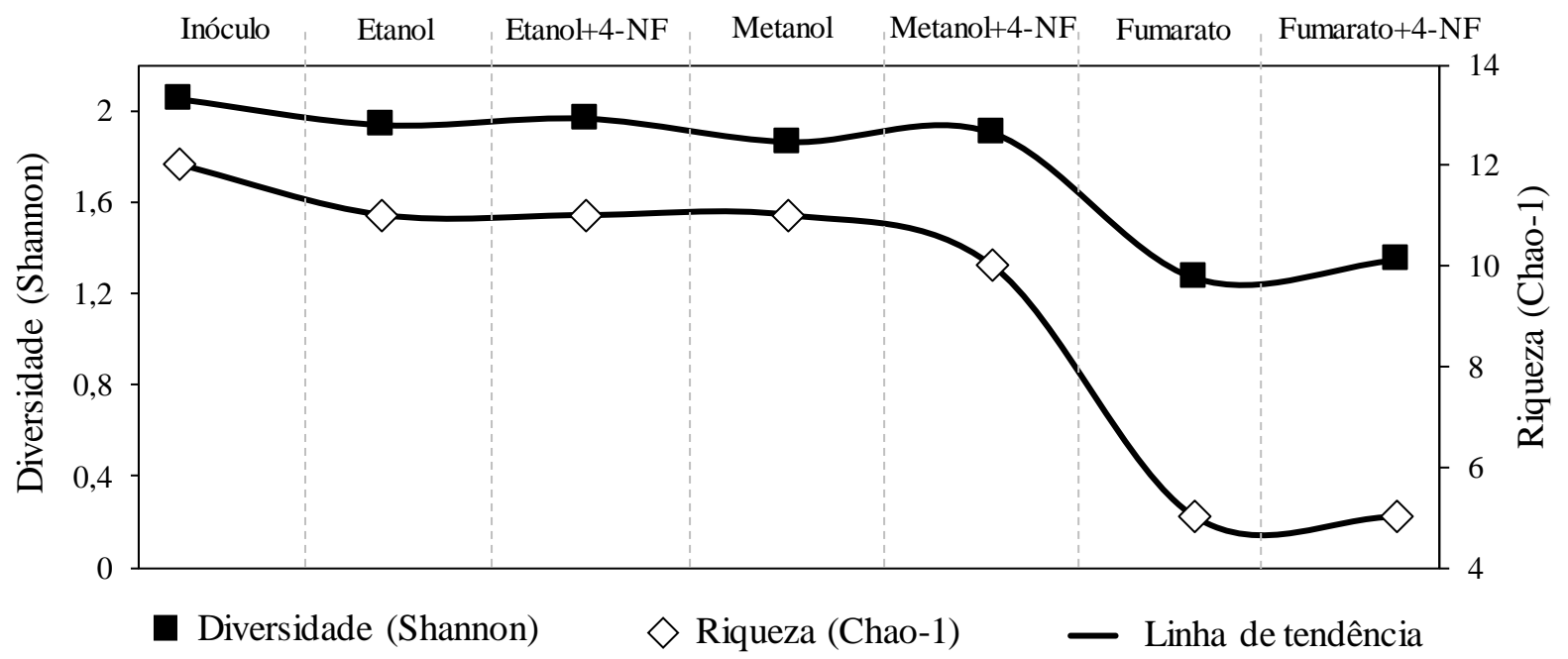

Fonte: $\mathrm{O}$ autor.

Constatou-se aumento do índice de diversidade em todos os ensaios com adição de 4NF (Etanol+4-NF, Metanol+4-NF e Fumarato+4-NF) em comparação aos ensaios controle (Etanol, Metanol e Fumarato), proporcionando redução da dominância como pode ser observado na Figura 5.18. 
Figura 5.18 - Variação dos índices de diversidade e dominância para o Domínio Archaea em ensaios em reatores em batelada e inóculo.

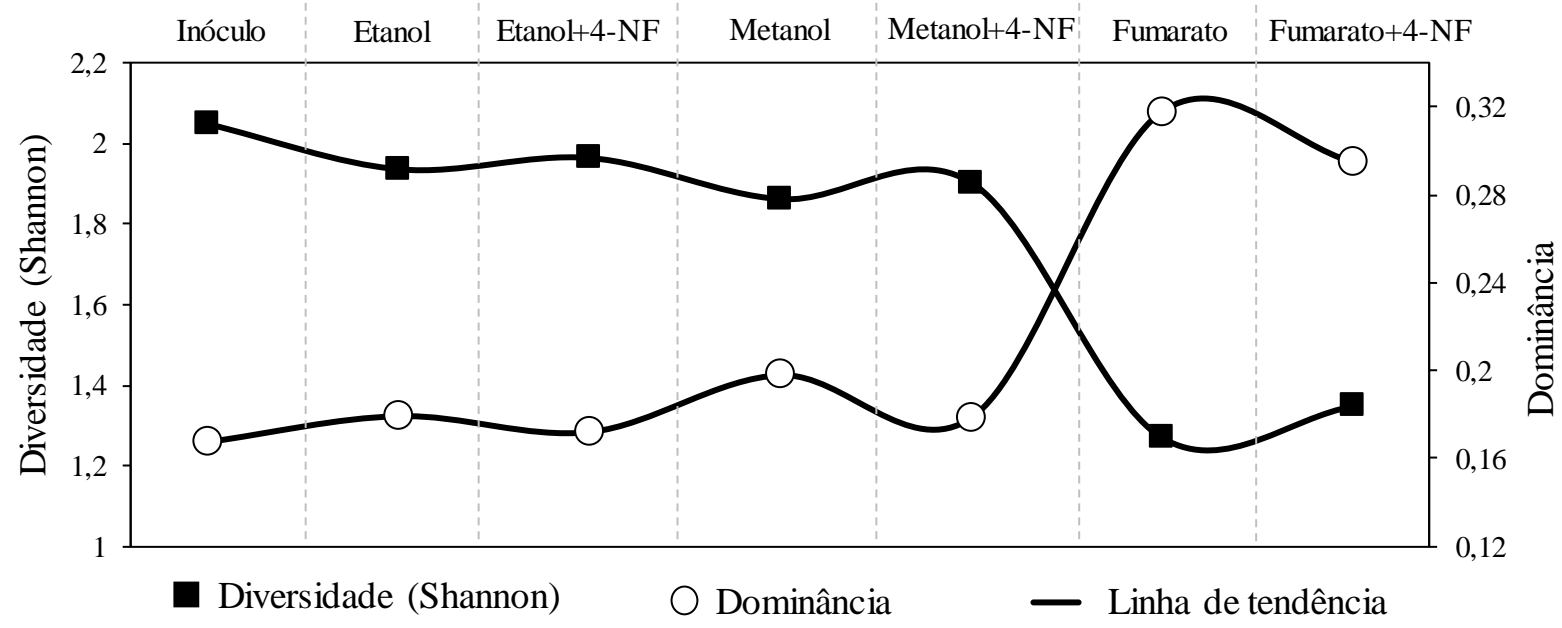

Fonte: $\mathrm{O}$ autor.

Motteran et al. (2014b) avaliaram o potencial metanogênico de lodo anaeróbio na presença de surfactante não iônico Álcool Etoxilado (LAE) em reatores em batelada e verificaram aumento no índice de diversidade para o domínio Archaea (de 2,42 para 2,57), para ensaios com adição de $\operatorname{LAE}\left(16,3 \pm 2,5 \mathrm{mg} \mathrm{L}^{-1}\right)$ em comparação ao ensaio controle (sem adição de LAE), similar ao comportamento verificado no presente estudo.

\subsection{Monitoramento do reator de leito fluidificado}

Neste capítulo serão apresentados os resultados referentes à operação e monitoramento do Reator Anaeróbio de Leito Fluidificado em escala aumentada. Serão abordados os parâmetros físico-químicos de monitoramento e caracterização microbiana ao final das fases operacionais.

\subsubsection{Remoção de matéria orgânica}

Após etapa inicial de inoculação em circuito fechado iniciou-se a operação do reator em circuito aberto, no qual a duração das fases operacionais foi determinada de acordo com a estabilidade de remoção de matéria orgânica (DQO) e 4-Nonilfenol (4-NF). O tempo de 
operação de cada fase foi de 40, 14, 35, 140 e 58 dias, para a Fase de Adaptação, Fase I, II, III e IV, respectivamente.

Foi realizada a redução da concentração de co-substrato (etanol) a composição do meio de cultura (Tabelas 4.2 e 4.3) para Fase IV (58 dias de duração), com o objetivo de avaliar a comportamento do reator quanto a remoção de 4-NF em condição de limitação nutricional. A adição de co-substrato ao meio reacional pode favorecer o estabelecimento de comunidade degradadora do composto de interesse (OKADA et al., 2014) e, uma vez adaptada, a comunidade microbiana pode continuar degradado o composto tóxico mesmo na ausência do co-substrato (SANZ et al., 2003; DUARTE et al., 2010; MACEDO et al., 2015).

A etapa de inoculação (circuito fechado) teve duração de 20 dias e foram verificados

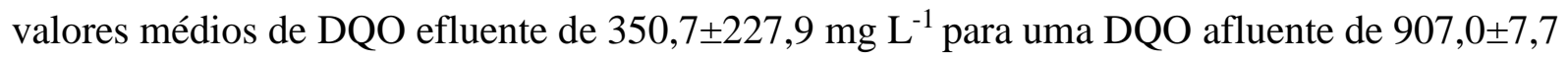
$\mathrm{mg} \mathrm{L}^{-1}$. Após esse período tiveram início as etapas em sistema contínuo sem adição de 4-NF (Adaptação e Fase I) e com adição de 4-NF (Fase II, III e IV).

Foram verificados valores médios de DQO afluente para as fases sem adição de 4-NF de $905,8 \pm 19,7 \mathrm{mg} \mathrm{L}^{-1}$ (Adaptação) e $894,4 \pm 14,1 \mathrm{mg} \mathrm{L}^{-1}$ (Fase I). Para as fases com adição de 4-NF os valores médios de DQO afluente foram de 877,6 $\pm 13,5 \mathrm{mg} \mathrm{L}^{-1}$ (Fase II); 939,7 $\pm 23,1$ $\mathrm{mg} \mathrm{L}^{-1}$ (Fase III) e 568,0 $\pm 18,0 \mathrm{mg} \mathrm{L}^{-1}$ (Fase IV). A redução da DQO afluente verificada na Fase IV $\left(568,0 \pm 18,0 \mathrm{mg} \mathrm{L}^{-1}\right)$ foi devido a retirada do co-substrato da composição do meio de cultura (Tabelas 4.2 e 4.3), o qual foi adicionado em todas as fases anteriores (Inoculação, Adaptação, Fase I, II e III) de operação do RALF.

O maior valor médio para a DQO efluente $\left(337,36 \pm 106,0 \mathrm{mg} \mathrm{L}^{-1}\right)$ ocorreu na fase inicial de operação em modo contínuo (Adaptação). Isto pode ter ocorrido devido a adaptação da comunidade do leito de areia a configuração reacional e composição nutricional do meio de cultura (Tabelas 4.2 e 4.3), o que resultou também na menor eficiência de remoção de DQO

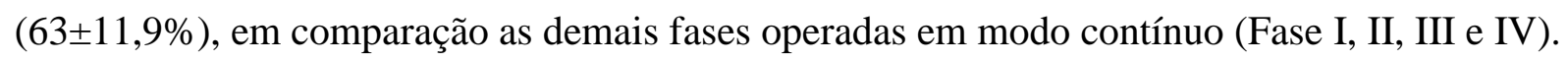

As menores concentrações médias de DQO efluente foram verificadas para as Fases III $\left(32,8 \pm 11,8 \mathrm{mg} \mathrm{L}^{-1}\right)$ e IV $\left(29,11 \pm 8,7 \mathrm{mg} \mathrm{L}^{-1}\right)$, seguidas da Fase II $\left(50,2 \pm 11,2 \mathrm{mg} \mathrm{L}^{-1}\right)$ e Fase I $\left(72,2 \pm 53,2 \mathrm{mg} \mathrm{L}^{-1}\right)$. Observou-se tendência de redução da concentração de média de DQO efluente com o aumento do período operacional, apesar de os valores não apresentarem diferença significativa. A fase sem adição de 4-NF (Fase I) diferiu significativamente das fases com a as maiores doses de 4-NF (Fase III e IV).

As maiores eficiências médias de remoção de DQO foram verificadas para as Fases III $(97,0 \pm 1,3 \%)$ e IV $(95 \pm 1,5 \%)$, seguidas da Fase II $(94,0 \pm 1,2 \%)$ e Fase I $(90,34 \pm 6,1 \%)$. A eficiência de remoção de DQO para a fase operacional sem adição de 4-NF (Fase I) diferiu 
significativamente das fases com maiores concentrações de 4-NF (Fase III e IV). A fase inicial de adição de 4-NF (Fase II) não diferiu significativamente da fase controle (Fase I) nem das fases com maiores concentrações de 4-NF (Fase III e IV). Os valores médios para DQO afluente, efluente (filtrado) e eficiência de remoção são apresentadas na Tabela 5.15, bem como sua comparação estatística.

Tabela 5.15 - DQO média afluente, efluente e eficiência de remoção.

\begin{tabular}{|c|c|c|c|}
\hline \multirow{2}{*}{ FASES } & \multicolumn{2}{|c|}{ DQO $\left(\mathrm{mg} \mathrm{L}^{-1}\right)$} & \multirow{2}{*}{ Eficiência (\%) } \\
\hline & Afluente & Efluente filtrado & \\
\hline Adaptação & $905,8 \pm 19,7 \mathrm{~b}$ & $337,36 \pm 106,0$ a & $63 \pm 11,9 c$ \\
\hline Fase I & $894,4 \pm 14,1 b^{*} *$ & $72,2 \pm 53,2 \mathrm{~b}$ & $90,34 \pm 6,1 \mathrm{~b}$ \\
\hline Fase II & $877,6 \pm 13,5 \mathrm{c}$ & $50,2 \pm 11,2 \mathrm{bc}$ & $94,0 \pm 1,2 \mathrm{ab}$ \\
\hline Fase III & $939,7 \pm 23,1 \mathrm{a}$ & $32,8 \pm 11,8 \mathrm{c}$ & $97,0 \pm 1,3 \mathrm{a}$ \\
\hline Fase IV & $568,0 \pm 18,0 \mathrm{~d}$ & $29,11 \pm 8,7 \mathrm{c}$ & $95 \pm 1,5 \mathrm{a}$ \\
\hline
\end{tabular}

* Médias seguidas da mesma letra não diferem pelo teste de Tukey, a 5\% de probabilidade de erro.

A concentração de etanol adicionada ao meio de cultura (Tabelas 4.2 e 4.3) foi de 192,2 $\pm 50,8 \mathrm{mg} \mathrm{L}^{-1}$ para as fases de Inoculação, Adaptação, Fase I, II, III. Considerando o fator de equivalência de etanol em DQO de 2,09 mg DQO mg-1 EtOH (FUESS, 2017), a concentração de etanol equivaleu a $402 \mathrm{mg} \mathrm{DQO} \mathrm{L}^{-1}$, assim, pode-se verificar que a redução da DQO afluente

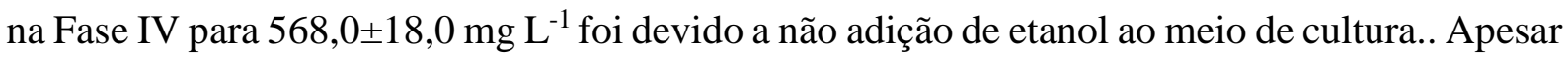
da não adição de etanol a composição do meio de cultura na Fase IV, a solução de 4-NF usada na alimentação do reator foi confeccionada em $50 \%$ de etanol afim de promover a solubilização do contaminante, uma vez que este apresenta hidrofobicidade. Deste modo, para a Fase IV a concentração de etanol afluente foi de $20,2 \pm 8,8 \mathrm{mg} \mathrm{L}^{-1}$. Não foi verificado etanol residual no efluente do RALF, tanto para as fases com adição de $192,2 \pm 50,8 \mathrm{mg} \mathrm{L}^{-1}$ de etanol afluente (Adaptação, Fase I, II, III), quanto para adição de 20,2 $\pm 8,8 \mathrm{mg} \mathrm{L}^{-1}$ (Fase IV).

As concentrações de ácidos orgânicos voláteis (AOV) no efluente estiveram abaixo do limite de detecção, impossibilitado sua quantificação. Isto pode ter ocorrido devido as altas eficiências de remoção de DQO (91 a 97\%) e baixas concentrações de DQO efluente $(29,11 \pm 8,7$ a $\left.72,2 \pm 53,2 \mathrm{mg} \mathrm{L}^{-1}\right)$. 
A adição de 4-NF não provocou alteração significativa na eficiência de remoção de DQO filtrada. A eficiência média de remoção de DQO $(94,0 \pm 1,2 \%)$ da fase inicial de adição e 4-NF (Fase II) não diferiu significativamente da eficiência da fase controle $(90,34 \pm 6,1 \%)$, sem adição de 4-NF (Fase I).

Murdoch e Sanin (2016) avaliaram o comportamento de digestores anaeróbios (2 litros) semi contínuos com adição de Nonilfenol Dietoxilado (3000 $\left.\mu \mathrm{g} \mathrm{L}^{-1}\right)$ em picos; os autores verificaram que a adição do composto (Nonilfenol Dietoxilado) não provocou alteração no pH (7,0 a 7,6), na eficiência de remoção de DQO (55 a 59\%), produção de metano (0,374 a 0,388 $\mathrm{L} \mathrm{CH}_{4} \mathrm{~L}^{-1}$ dia $\left.^{-1}\right)$. Assim, as maiores eficiências médias de remoção de DQO verificadas para as Fases III $(97,0 \pm 1,3 \%)$ e IV $(95 \pm 1,5 \%)$ podem estar relacionadas ao tempo de operação do RALF e à estabilidade desta configuração reacional.

Oliveira et al. (2010) avaliaram a remoção de surfactante aniônico LAS (20 mg L $\left.{ }^{-1}\right) \mathrm{em}$ reator anaeróbio de leito fluidificado em escala de bancada $(353 \mathrm{ml})$ semelhante ao usado neste trabalho. O reator foi alimentado com meio de cultura ${ }^{20}$, TDH de $18 \mathrm{~h}$ e operado por 100 dias. Os autores verificaram eficiência de remoção de DQO de $97 \pm 2 \%$ para $560 \mathrm{mg} \mathrm{L}^{-1}$ afluente, próximo aos verificados neste trabalho. Apesar de Oliveira et al. (2010) ter utilizado diferente contaminante do presente trabalho (4-NF), os autores verificaram estabilidade da configuração reacional (RALF) para a degradação do composto de interesse (LAS), similar ao verificado no presente estudo.

A aplicabilidade desta configuração reacional (RALF) para a degradação de outros compostos tóxicos também já foi relatada por Motteran et al. (2014), que utilizaram RALF em escala de bancada $(1.256 \mathrm{~mL})$ para avaliar a degradação do surfactante não iônico Álcool Etoxilado (4,7 a 107,4 $\mathrm{mg} \mathrm{L}^{-1}$ ) em meio de cultura ${ }^{21}$, com TDH de 18 h e tempo de operação de 492 dias. Foi verificada máxima eficiência de remoção de DQO de 93ะ2\% para $735 \pm 87$ mg $\mathrm{L}^{-1}$ afluente, próximo as eficiências de remoção de DQO verificadas no presente trabalho (90 a $97 \%)$.

Por meio da análise temporal (Figura 5.19.), verificou-se estabilidade de remoção de DQO após a fase de adaptação da biomassa a configuração reacional (RALF) e ao meio de cultura (Tabelas 4.2 e 4.3). A adição de 4-NF a partir da Fase II não provocou alteração na

\footnotetext{
${ }^{20}$ Composição do meio de cultura usado por Oliveira et al. (2010): extrato de levedura (500 $\left.\mathrm{mg} \mathrm{L}^{-1}\right)$, sacarose (80 $\left.\mathrm{mg} \mathrm{L}^{-1}\right)$, bicarbonato de sódio $\left(\mathrm{mg} \mathrm{L}^{-1}\right)$ e $5 \mathrm{~mL} \mathrm{~L}^{-1}$ de solução salina $\left(50,0 \mathrm{~g} \mathrm{~L}^{-1} \mathrm{de} \mathrm{NaCl}, 1,4 \mathrm{mg} \mathrm{L} \mathrm{Le}^{-1} \mathrm{MgCl}_{2} 6 \mathrm{H}_{2} \mathrm{O}\right.$ e $0,9 \mathrm{~g} \mathrm{~L}^{-1}$ de $\mathrm{CaCl}_{2}-2 \mathrm{H}_{2} \mathrm{O}$ ).

${ }^{21}$ Composição do meio de cultura usado Motteran et al. (2014): extrato de levedura (500 mg L $\left.{ }^{-1}\right)$, sacarose (80 mg $\left.\mathrm{L}^{-1}\right)$, bicarbonato de sódio $\left(\mathrm{mg} \mathrm{L}^{-1}\right)$ e $5 \mathrm{~mL} \mathrm{~L}^{-1}$ de solução salina $\left(50,0 \mathrm{~g} \mathrm{~L}^{-1} \mathrm{de} \mathrm{NaCl}, 1,4 \mathrm{mg} \mathrm{L} \mathrm{de}^{-1} \mathrm{MgCl}_{2} 6 \mathrm{H}_{2} \mathrm{O}\right.$ e $\left.0,9 \mathrm{~g} \mathrm{~L}^{-1} \mathrm{de} \mathrm{CaCl}_{2}-2 \mathrm{H}_{2} \mathrm{O}\right)$.
} 
eficiência de remoção de matéria orgânica. O mesmo comportamento foi verificado com o aumento da dose de 4-NF durante a Fase III. A redução da concentração de DQO afluente na fase IV não provocou alterações na eficiência de remoção de matéria orgânica. A variação temporal de DQO afluente, efluente e eficiência de remoção pode ser verificada na Figura 5.19.

Figura 5.19 - Variação temporal de DQO afluente, efluente e eficiência de remoção.

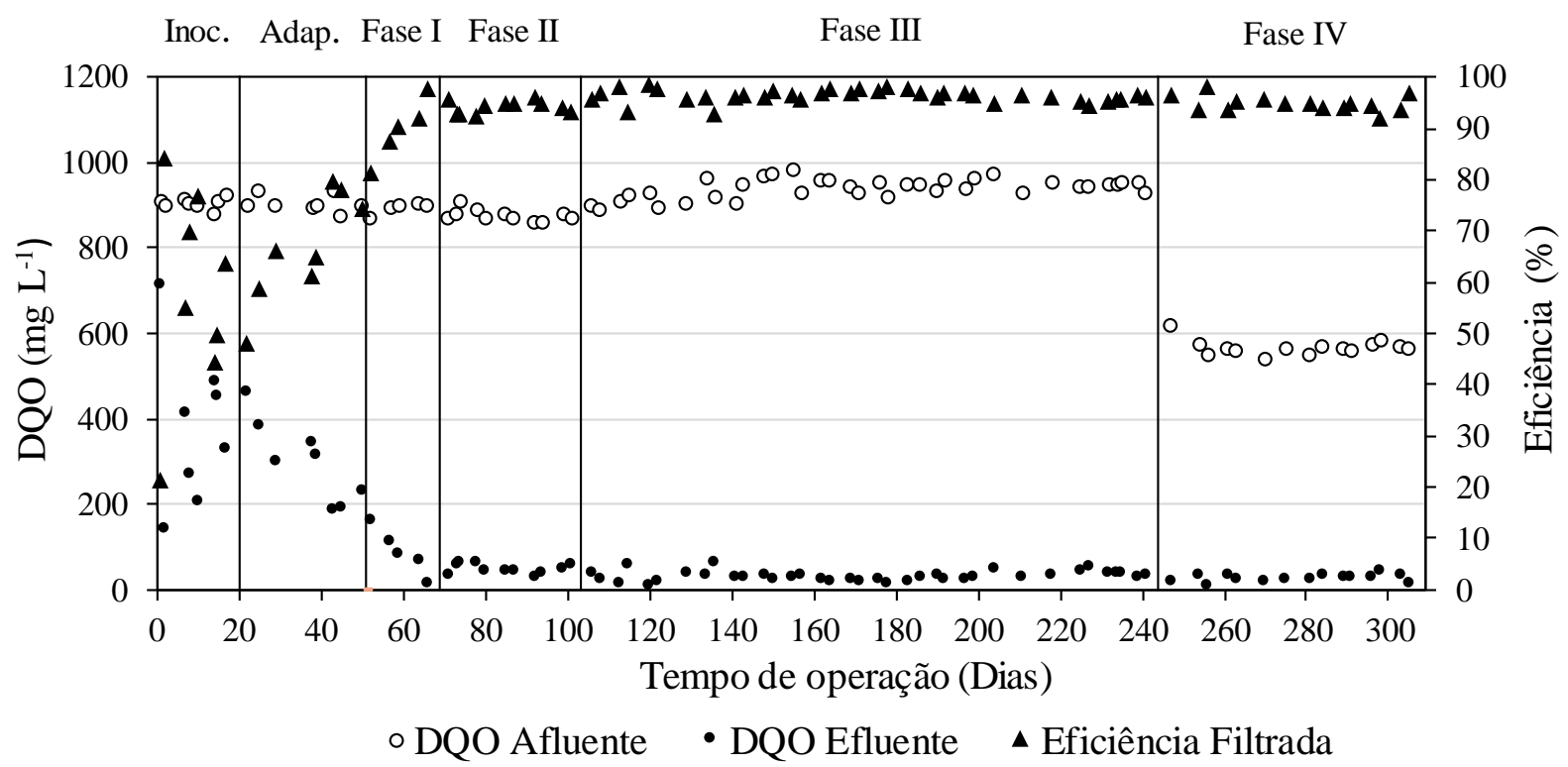

Fonte: O autor.

Zhang et al. (2008), avaliaram a remoção do surfactante Nonilfenol Etoxilado (NFe) em reator anaeróbio de manta de lodo (UASB) em escala de bancada (4 L), alimentado continuamente com esgoto doméstico e TDH de 5,5, 8,7 e 15,8 h. Os autores verificaram que as concentrações de Nonilfenol etoxilado (em picos de $15 \mathrm{mg} \mathrm{L}^{-1}$ a cada $12 \mathrm{~h}$ ) não interferiram na eficiência de remoção de matéria orgânica, com 56,8 $\pm 6,5$ a $60,1 \pm 4,2 \%$ de eficiência para DQO afluente de $232 \pm 15 \mathrm{mg} \mathrm{L}^{-1}$. As altas concentrações de $\mathrm{NFe}$ aplicadas $\left(15 \mathrm{mg} \mathrm{L}^{-1}\right)$ não foram suficientes para reduzir a eficiência do reator (UASB). Apesar de, no presente estudo, ter sido usada diferente configuração reacional (RALF), os valores relatados por Zhang et al. (2008) dão um indicativo da robustez do processo biológico de tratamento de esgoto frente a presença de desregulador endócrinos, como o caso do 4-Nonilfenol.

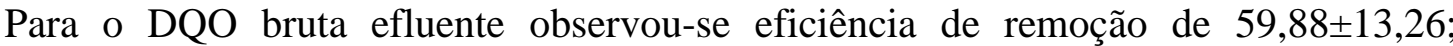
$82,53 \pm 8,90 ; 88,01 \pm 3,00 ; 93,25 \pm 1,49$ e 91,02 $\pm 1,68 \%$ para a Fase de Adaptação, Fase I, II, III e IV, respectivamente (Tabela 5.16). 
Tabela 5.16 - Valores médios de DQO bruta afluente, efluente e eficiência de remoção.

\begin{tabular}{cccc}
\hline \multirow{2}{*}{ FASES } & \multicolumn{2}{c}{ DQO bruta $\left(\mathrm{mg} \mathrm{L}^{-1}\right)$} & Eficiência (\%) \\
\cline { 2 - 3 } & Afluente & Efluente bruto & \\
\hline Adaptação & $905,8 \pm 19,7 \mathrm{~b}$ & $362,29 \pm 117,34 \mathrm{a}$ & $59,88 \pm 13,26 \mathrm{c}$ \\
Fase I & $894,4 \pm 14,1 \mathrm{bc} *$ & $155,60 \pm 77,85 \mathrm{~b}$ & $82,53 \pm 8,90 \mathrm{~b}$ \\
Fase II & $877,6 \pm 13,5 \mathrm{c}$ & $105,25 \pm 27,59 \mathrm{bc}$ & $88,01 \pm 3,00 \mathrm{ab}$ \\
Fase III & $939,7 \pm 23,1 \mathrm{a}$ & $62,82 \pm 13,48 \mathrm{c}$ & $93,25 \pm 1,49 \mathrm{a}$ \\
Fase IV & $568,0 \pm 18,0 \mathrm{~d}$ & $50,96 \pm 10,04 \mathrm{c}$ & $91,02 \pm 1,68 \mathrm{a}$ \\
\hline
\end{tabular}

* Médias seguidas da mesma letra não diferem pelo teste de Tukey, a 5\% de probabilidade de erro.

Para remoção de DQO bruta verificou-se comportamento semelhante aquele observado para DQO filtrada, sendo verificado para as fases com adição de 4-NF (Fases II, III e IV) diferença significativa quando comparado as etapas sem adição de 4-NF (Fases de Adaptação e Fase 1). Esta diferença pode ter sido causada pelo tempo de operação do reator e não por algum possível efeito tóxico do surfactante, uma vez que foi verificado tendência de aumento da eficiência de remoção de DQO bruta, conforme aumento do tempo operacional.

Os altos valores de eficiência de remoção de DQO verificados no presente trabalho, foram atingidos devido às características do reator de leito fluidificado. Provavelmente, o sistema de mistura completa com alta recirculação, associado a imobilização da biomassa no material suporte e diluição inicial do afluente, tenham favorecido o contato e disponibilidade do substrato para os microrganismos, em relação às outras configurações reacionais (SHIEH; KEENAN, 1986; IZA，1991; METCALF; EDDY, 2003; DENG et al., 2016; BELLO; RAMAN; PURUSHOTHAMAN, 2017).

A estabilidade desta configuração reacional (RALF) proporcionou um efluente clarificado, evidenciado pelas baixas concentrações de DQO bruta no efluente $(155,60 \pm 77 \mathrm{mg}$ $\mathrm{L}^{-1}$ para Fase I; $105,25 \pm 27 \mathrm{mg} \mathrm{L}^{-1}$ para Fase II; 62,82 $\pm 13 \mathrm{mg} \mathrm{L}^{-1}$ para Fase III e 50,96 $\pm 10,04$ mg L ${ }^{-1}$ para Fase IV). A comparação entre DQO efluente (bruta e filtrada), eficiência de remoção (bruta e filtrada) para cada fase de operação do RALF pode ser verificada na Figura 5.20 . 
Figura 5.20 - Representação em box-plot para DQO afluente, efluente (bruta e filtrada) e eficiências de remoção (bruta e filtrada) para cada fase de operação do RALF.

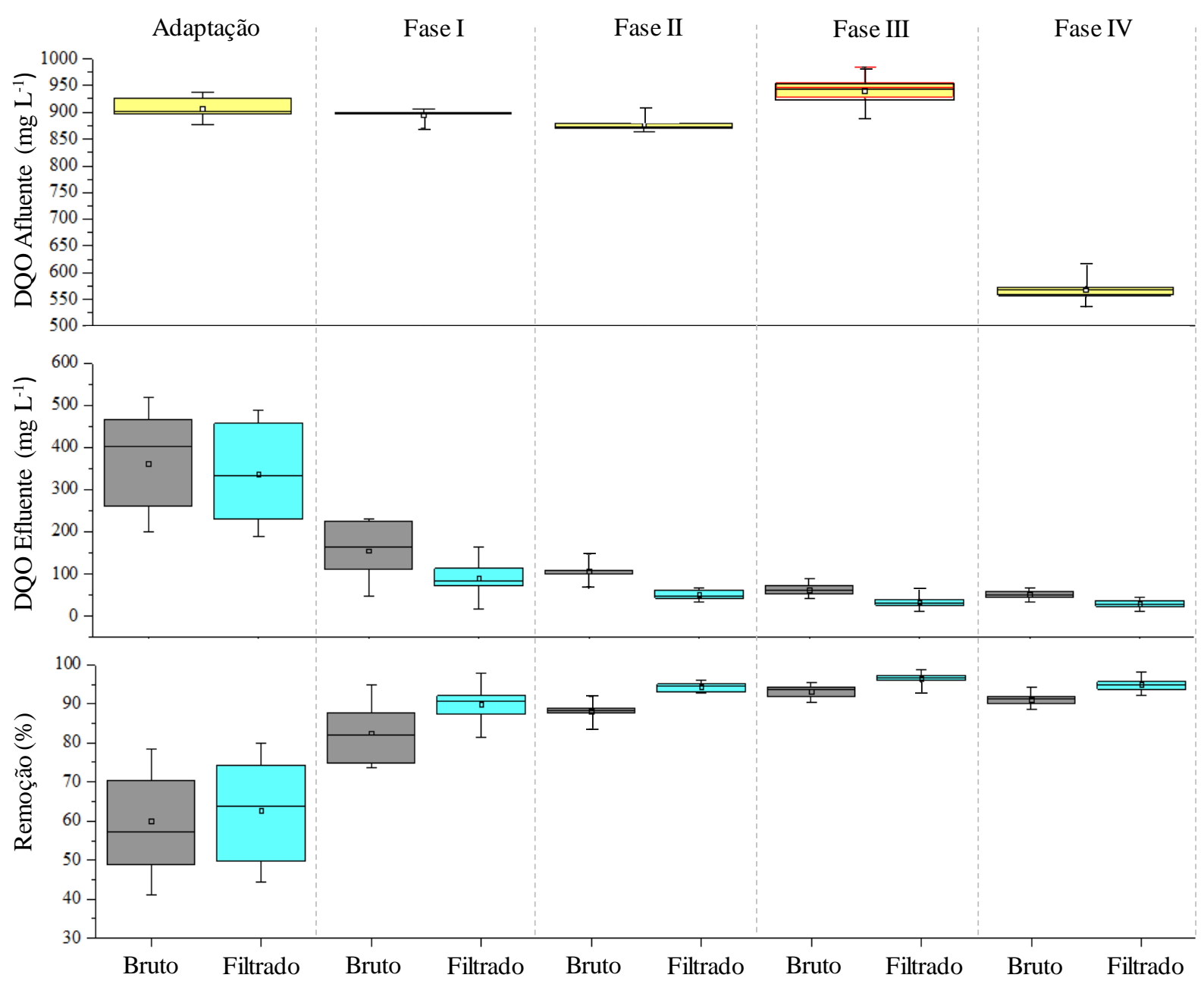

Fonte: $\mathrm{O}$ autor.

A Carga Orgânica Volumétrica (COV) aplicada ao reator foi de 1,15 $\pm 0,03 ; 1,14 \pm 0,02$;

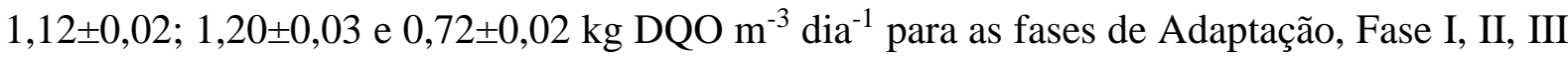
e IV, respectivamente. A redução da COV não provocou alteração significativa na eficiência de remoção de DQO filtrada e bruta, em função do tempo como pode ser verificado na Figura 5.21 . 
Figura 5.21 - Variação temporal da Carga Orgânica Volumétrica.

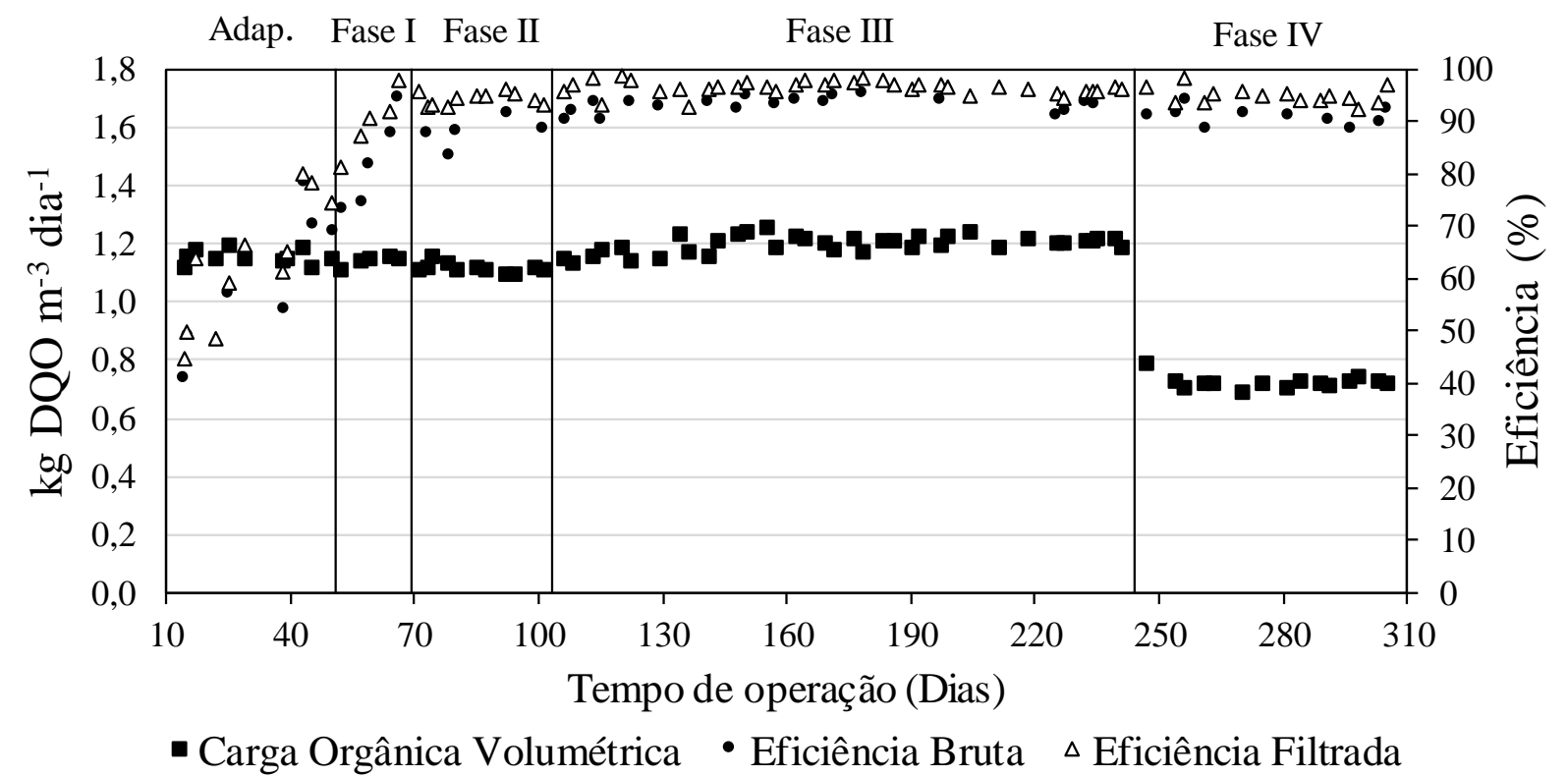

Fonte: $\mathrm{O}$ autor.

Observou-se estabilidade da COV aplicada em todas as fases operacionais em modo contínuo (Adaptação, Fase I, II, III e IV). A redução da COV na Fase IV foi provocada pela diminuição da concentração de co-substrato (etanol) da composição do meio de cultura (Tabela 4.2 e Tabela 4.3).

Na Fase IV (58 dias de duração), foi realizada adição de co-substrato (etanol) a composição do meio de cultura (Tabela 4.2 e Tabela 4.3), como estratégia para aumentar a eficiência de degradação de 4-NF. A adição de co-substrato a alimentação pode subsidiar o desenvolvimento de comunidade degradadora do composto de interesse (OKADA et al., 2014) e, uma vez adaptada, a comunidade microbiana pode consumir o composto tóxico mesmo na ausência do co-substrato (SANZ et al., 2003; DUARTE et al., 2010; MACEDO et al., 2015).

Os valores de COV usados neste trabalho foram similares aos aplicados por Motteran (2013) (0,8 a 1,18 kg DQO m ${ }^{-3}$ dia $\left.^{-1}\right)$ e Braga (2014) (0,53 a 1,05 kg DQO m${ }^{-3}$ dia $\left.^{-1}\right)$, usando a mesma configuração reacional (RALF), alcançando eficiências máximas de remoção de DQO de cerca de $93 \pm 2 \%$ e $90,9 \pm 3,2 \%$, respectivamente. 


\subsubsection{Temperatura}

A temperatura ambiente média do período operacional de monitoramento do RALF foi de $21,02 \pm 2,64{ }^{\circ} \mathrm{C}$. Os valores médios registrados em cada fase de operação para temperatura diária Máxima, Mínima e Média e comparação estatística estão apresentados na Tabela 5.17.

Tabela 5.17 - Valores médios de temperatura diária máxima, mínima e média.

\begin{tabular}{lccc}
\hline \multicolumn{1}{c}{ Fases } & Máxima $\left({ }^{\circ} \mathrm{C}\right)$ & Mínima $\left({ }^{\circ} \mathrm{C}\right)$ & Média $\left({ }^{\circ} \mathrm{C}\right)$ \\
\hline Inoculação & $28,1 \pm 2,5 \mathrm{ab}$ & $18,1 \pm 1,2 \mathrm{abc}$ & $21,9 \pm 1,7 \mathrm{ab}$ \\
Adaptação & $28,8 \pm 2,5 \mathrm{a}$ & $18,5 \pm 1,3 \mathrm{ab}$ & $22,6 \pm 1,5 \mathrm{a}$ \\
Fase I & $30,4 \pm 1,0 \mathrm{a}^{*}$ & $19,6 \pm 0,9 \mathrm{a}$ & $24,1 \pm 1,3 \mathrm{a}$ \\
Fase II & $28,4 \pm 1,9 \mathrm{a}$ & $17,4 \pm 1,6 \mathrm{bc}$ & $21,7 \pm 1,4 \mathrm{~b}$ \\
Fase III & $26,3 \pm 3,3 \mathrm{~b}$ & $14,6 \pm 2,7 \mathrm{~d}$ & $19,6 \pm 2,7 \mathrm{c}$ \\
Fase IV & $28,3 \pm 3,8 \mathrm{a}$ & $16,9 \pm 2,0 \mathrm{c}$ & $21,7 \pm 2,2 \mathrm{~b}$ \\
\hline
\end{tabular}

* Médias seguidas da mesma letra não diferem pelo teste de Tukey, a 5\% de probabilidade de erro.

As maiores médias registradas para a temperatura máxima diária foram nas Fases de Adaptação, Fase I, Fase II e Fase IV, as quais não diferiram significativamente. A menor média registrada para a temperatura mínima diária foi na Fase III $\left(14,6 \pm 2,7^{\circ} \mathrm{C}\right)$, seguida das Fases IV $\left(16,9 \pm 2,0{ }^{\circ} \mathrm{C}\right)$ e Fase II $\left(17,4 \pm 1,6^{\circ} \mathrm{C}\right)$.

Em relação a temperatura média, verificou-se o menor valor médio para a fase III $\left(14,6 \pm 2,7^{\circ} \mathrm{C}\right)$. Durante a Fase III também foi verificada a maior amplitude térmica $\left(25,6^{\circ} \mathrm{C}\right)$, cuja temperatura mínima e máxima observadas foram de $6,6^{\circ} \mathrm{C}$ e $32,2{ }^{\circ} \mathrm{C}$, respectivamente. Os valores registrados para temperatura diária média, máxima e mínima durante as fases operacionais podem ser visualizados na Figura 5.22. 
Figura 5.22 - Temperatura diária média, máxima e mínima durante as fases de operação do RALF.

Inoc. Adap. Fase I Fase II

Fase III

Fase IV

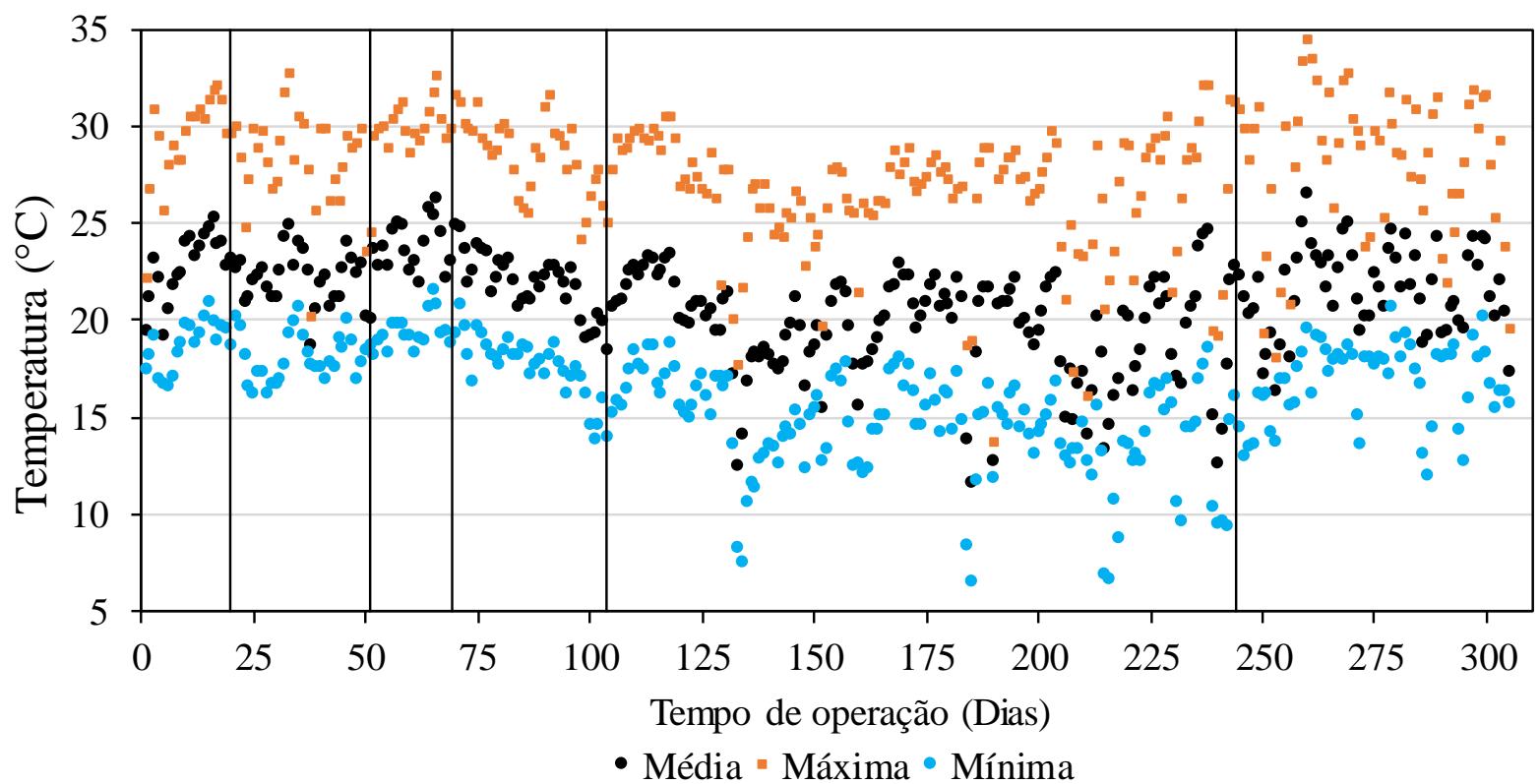

Fonte: $\mathrm{O}$ autor.

Neste estudo, a variação de temperatura não interferiu na eficiência de remoção de matéria orgânica (DQO bruta e filtrada) como pode ser verificado tanto pelo gráfico temporal Figura 5.19. quanto pelos baixos desvios padrões dos box-plot da Figura 5.20.

\subsection{3 pH e Alcalinidade}

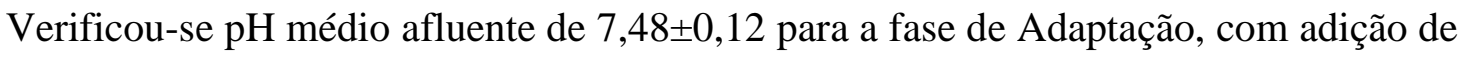
alcalinizante ao meio de cultura e 6,76 $\pm 0,07$ para as demais fases operacionais, as quais não foi observado diferença significativa. Para os valores médios afluente de $\mathrm{pH}$, Alcalinidade Parcial, Intermediária, Total e relação AI/AP não foi verificado diferença significativa para as Fases I, II, III e IV. Os valores afluentes observados para pH, Alcalinidade Parcial, Intermediária e Total, relação AI/AP e comparação estatísticas das médias estão incluídos na Tabela 5.18. 
Tabela 5.18 - Valores médios afluente e efluente de pH, Alcalinidade Parcial, Intermediária e Total e Relação AI/AP para as fases de operação do RALF.

\begin{tabular}{|c|c|c|c|c|c|}
\hline \multirow{2}{*}{ Fases } & \multirow{2}{*}{$\mathrm{pH}$} & \multicolumn{3}{|c|}{ Alcalinidade $\left(\mathrm{mg} \mathrm{CaCO}_{3} \mathrm{~L}^{-1}\right)$} & \multirow{2}{*}{$\mathrm{AI} / \mathrm{AP}$} \\
\hline & & $\mathrm{AP}$ & $\mathrm{AI}$ & AT & \\
\hline \multicolumn{6}{|c|}{ Afluente } \\
\hline Adaptação & $7,48 \pm 0,12$ a & $20,64 \pm 1,80 \mathrm{a}$ & $14,92 \pm 2,27 b$ & $35,56 \pm 2,71 \mathrm{a}$ & $0,73 \pm 0,14 b$ \\
\hline Fase I & $6,77 \pm 0,05 b$ & $14,23 \pm 1,09 b$ & $19,59 \pm 1,48 \mathrm{a}$ & $33,82 \pm 1,47 \mathrm{a}$ & $1,38 \pm 0,17 \mathrm{a}$ \\
\hline Fase II & $6,81 \pm 0,02 b$ & $13,47 \pm 1,89 \mathrm{~b}$ & $17,55 \pm 0,91 \mathrm{ab}$ & $31,02 \pm 1,58 \mathrm{a}$ & $1,32 \pm 0,23 \mathrm{a}$ \\
\hline Fase III & $6,82 \pm 0,05 b$ & $15,22 \pm 2,80 \mathrm{~b}$ & $17,38 \pm 0,79 \mathrm{ab}$ & $32,60 \pm 2,36 \mathrm{a}$ & $1,18 \pm 0,26 \mathrm{a}$ \\
\hline Fase IV & $6,69 \pm 0,03 b$ & $14,12 \pm 0,41 \mathrm{~b}$ & $19,63 \pm 1,49$ a & $33,75 \pm 1,90 \mathrm{a}$ & $1,39 \pm 0,07 \mathrm{a}$ \\
\hline \multicolumn{6}{|c|}{ Efluente } \\
\hline Adaptação & $7,69 \pm 0,25 \mathrm{a}$ & $158,68 \pm 42,95 \mathrm{a}$ & $97,65 \pm 28,77$ a & $256,33 \pm 28,69 \mathrm{a}$ & $0,62 \pm 0,33 \mathrm{a}$ \\
\hline Fase I & $7,69 \pm 0,25 \mathrm{~b}$ & $103,03 \pm 29,86 b$ & $59,47 \pm 33,54 \mathrm{~b}$ & $178,35 \pm 54,82 \mathrm{~b}$ & $0,58 \pm 0,08 \mathrm{ab}$ \\
\hline Fase II & $7,45 \pm 0,20 \mathrm{~b}$ & $92,21 \pm 6,38 b^{*}$ & $32,26 \pm 4,61 \mathrm{bc}$ & $124,47 \pm 8,70 \mathrm{~b}$ & $0,35 \pm 0,05 \mathrm{bc}$ \\
\hline Fase III & $7,43 \pm 0,16 b$ & $101,44 \pm 26,87 \mathrm{~b}$ & $30,67 \pm 8,60 \mathrm{c}$ & $139,88 \pm 7,43 \mathrm{~b}$ & $0,30 \pm 0,05 \mathrm{c}$ \\
\hline Fase IV & $7,45 \pm 0,15 \mathrm{~b}$ & $110,13 \pm 13,70 \mathrm{~b}$ & $32,28 \pm 5,20 \mathrm{bc}$ & $132,73 \pm 18,75 \mathrm{~b}$ & $0,29 \pm 0,02 \mathrm{c}$ \\
\hline
\end{tabular}

* Médias seguidas da mesma letra não diferem pelo teste de Tukey, a 5\% de probabilidade de erro.

Os valores médios afluentes de $\mathrm{pH}, \mathrm{AP}, \mathrm{AI}$ e relação $\mathrm{AI} / \mathrm{AP}$ verificados na Fase de Adaptação diferiram significativamente das demais fases operacionais. Isso ocorreu devido à adição de alcalinizante (bicarbonato de sódio) à composição do meio de cultura (Tabelas 4.2 e 4.3) na fase de Adaptação, para garantir a estabilidade do sistema até que a comunidade microbiana estivesse adaptada as novas condições reacionais.

No monitoramento do efluente foram observados valores de $\mathrm{pH}$ de 7,69 $\pm 0,25$; $7,69 \pm 0,25 ; 7,45 \pm 0,20 ; 7,43 \pm 0,16$ e $7,45 \pm 0,15$ para a Fase de Adaptação, Fase I, II, III e IV, respectivamente. Durante todo o período operacional verificou-se $\mathrm{pH}$ efluente médio de $7,69 \pm 0,25$ para a fase com adição de alcalinizante ao meio de cultura (Adaptação) e 7,44 $\pm 0,18$ para as demais fases operacionais (Fase I, II, III e IV), as quais não diferiram significativamente. A comparação entre os valores de $\mathrm{pH}$ e alcalinidade total pode ser observada no box-plot da Figura 5.23. 
Figura 5.23 - Representação em box-plot para pH (afluente e efluente) e alcalinidade total (afluente e efluente) para cada fase de operação do RALF.

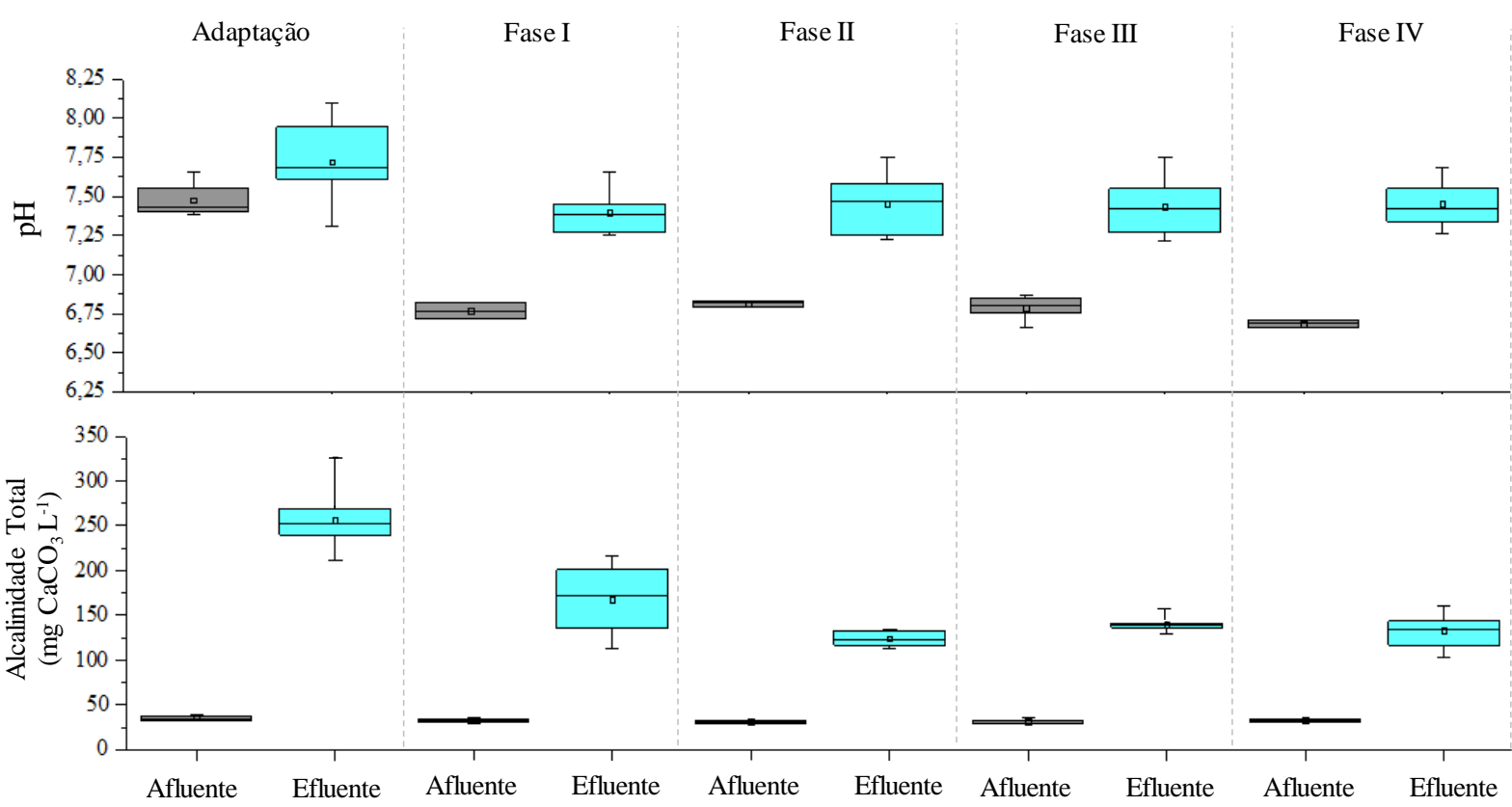

Fonte: $\mathrm{O}$ autor.

Em relação aos valores médios efluente de $\mathrm{pH}$, AP e AT não verificou-se diferença significativa para as Fases I, II, III e IV. Todavia, para todos os parâmetros analisados da Fase de Adaptação foi verificada diferença em relação as demais fases devido a retirada do alcalinizante na composição do meio de cultura (Tabela 4.2 e Tabela 4.3).

Para os valores de relação AI/AP verificou-se decréscimo ao longo do período operacional; ou seja, de $0,62 \pm 0,33 ; 0,58 \pm 0,08 ; 0,35 \pm 0,05 ; 0,30 \pm 0,05$ e $0,29 \pm 0,02$ para a Fase de Adaptação, Fase I, II, III e IV, respectivamente. De acordo com Ripley; Boyle e Converse (1986), valores de relação AI/AP relação acima de 0,3 indicam ocorrência de distúrbios no processo de digestão anaeróbia, contudo, este parâmetro não é fixo e pode variar de acordo com as especificidades de cada configuração reacional e composição nutricional do afluente tratado. Deste modo, a relação AI/AP é intrínseca a cada reator em condições estáveis (FORESTI, 1994; CHERNICHARO, 2007). O comportamento da alcalinidade parcial e intermediária, com seus respectivos valores de AI/AP para afluente e efluente pode ser observado nos box-plot da Figura 5.24 . 
Figura 5.24 - Representação em box-plot para alcalinidade parcial (afluente e efluente), alcalinidade intermediária (afluente e efluente) e relação AI/AP (afluente e efluente) para cada fase de operação do RALF.

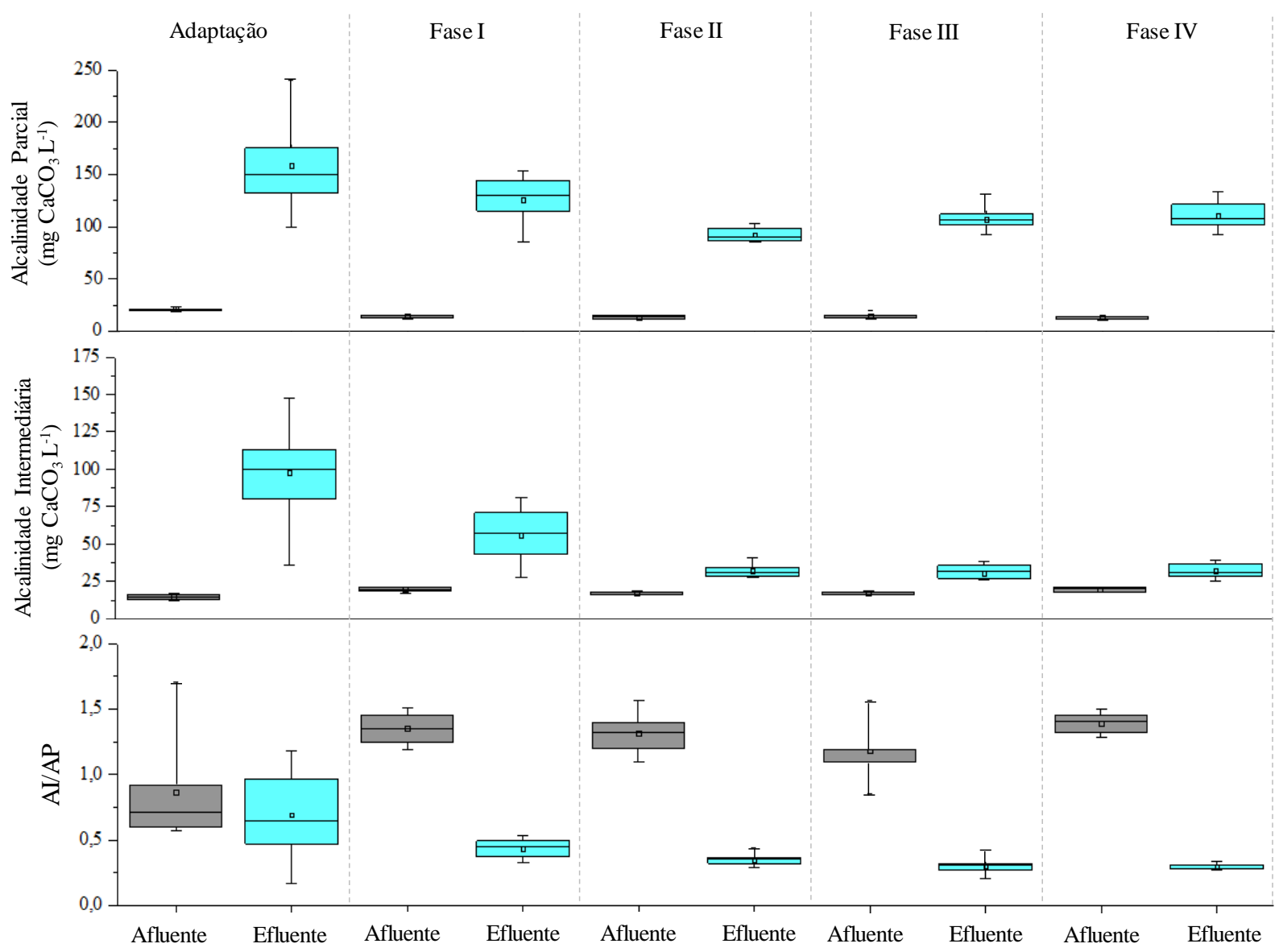

Fonte: $\mathrm{O}$ autor.

Braga et al. (2015) avaliaram a remoção do surfactante aniônico LAS em reator de leito fluidificado (RALF) em escala de bancada $(1.200 \mathrm{~mL})$, preenchido com areia como material suporte, operado por 489 dias em TDH de $18-23$ horas a temperatura de $30^{\circ} \mathrm{C}$, inoculado com lodo proveniente de reator UASB utilizado no tratamento de dejetos de suinocultura e alimentado com meio de cultura ${ }^{22}$ acrescido de água residuária de lavanderia comercial, com eficiência de remoção de DQO de 90,9 $\pm 13,0 \%$ (para afluente de $685 \pm 92 \mathrm{mg} \mathrm{L}^{-1}$ ) e $65,3 \pm 14,3 \%$ para LAS (para afluente de 23,3 $\pm 5,5 \mathrm{mg} \mathrm{L}^{-1}$ ); os autores verificaram relação AI/AP de $0,29 \pm 0,10$, similar ao verificado no presente estudo.

\footnotetext{
${ }^{22}$ Composição do meio de cultura usado por Braga et al. (2015): extrato de levedura (500 $\left.\mathrm{mg} \mathrm{L}^{-1}\right)$, sacarose (80 $\left.\mathrm{mg} \mathrm{L} \mathrm{L}^{-1}\right)$, bicarbonato de sódio $\left(\mathrm{mg} \mathrm{L}^{-1}\right)$ e $5 \mathrm{~mL} \mathrm{~L}^{-1}$ de solução salina $\left(50,0 \mathrm{~g} \mathrm{~L}^{-1} \mathrm{de} \mathrm{NaCl}, 1,4 \mathrm{mg} \mathrm{L}^{-1}\right.$ de $\mathrm{MgCl}_{2} 6 \mathrm{H}_{2} \mathrm{O}$

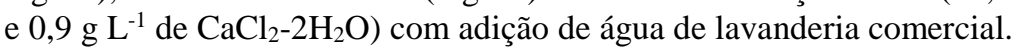


Para avaliar a amplitude de variação do pH e alcalinidade (parcial, intermediária e total), os valores da Tabela 5.18 foram usados para calcular o percentual de variação do efluente em relação ao afluente, para cada fase de operação do RALF. Assim, para a fase controle, sem adição de 4-NF (Fase I), houve aumento de 77\% na alcalinidade total efluente (em comparação ao afluente). Nas fases com adição de 4-NF (Fase II, III e IV) o aumento na alcalinidade total efluente foi equivalente a $75 \%$. Em todas as fases operacionais foi constatado aumento da alcalinidade (Intermediária, Parcial e Total) efluente em comparação a alcalinidade (Intermediária, Parcial e Total) afluente. A redução ou aumento percentual dos valores Efluente em comparação aos valores Afluente pode ser observada na Figura 5.25.

Figura 5.25 - Redução/Aumento percentual dos valores Efluente para pH, Alcalinidade parcial (AP), Alcalinidade Intermediária (AI) e Alcalinidade total (AT) para as fases de operação do RALF, em comparação aos valores Afluente.

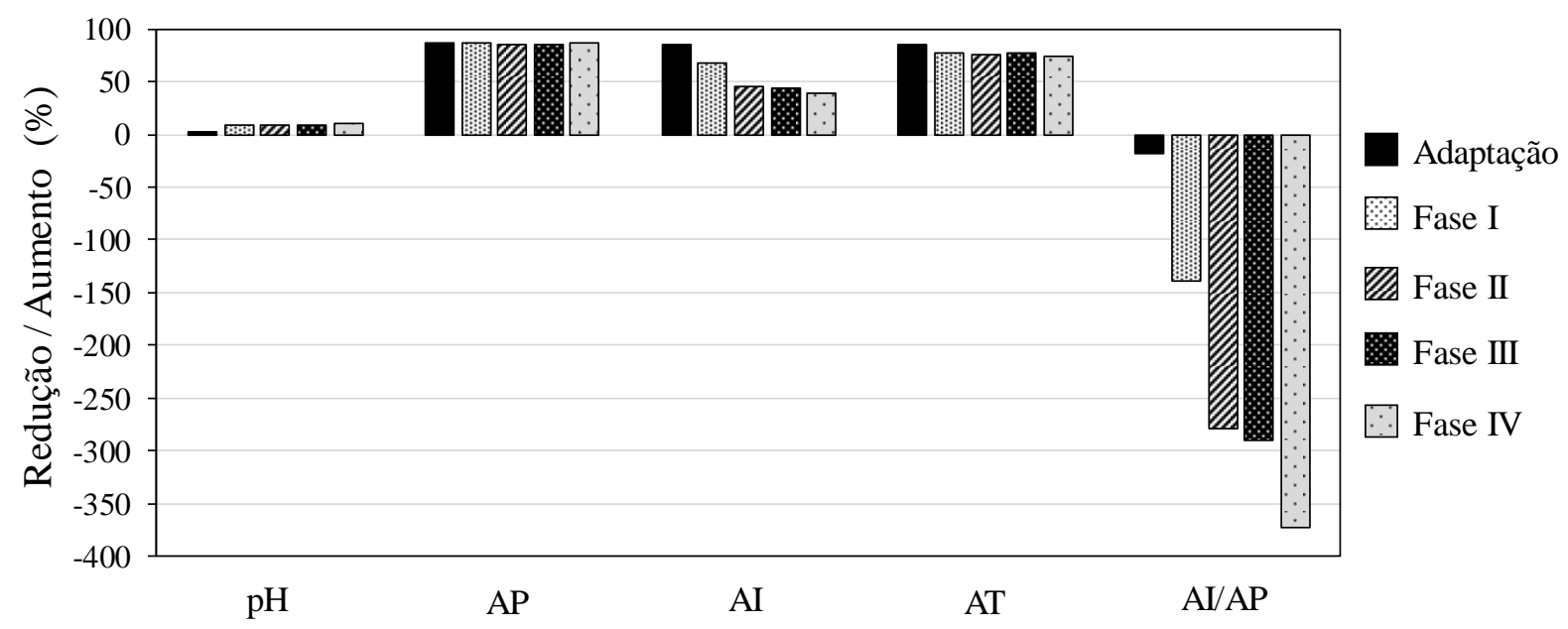

Fonte: $\mathrm{O}$ autor.

Verificou-se aumento percentual do pH efluente em comparação ao afluente para todas as fases de operação, correspondendo a 2,8\% de aumento na fase de Adaptação, 8,8\% na Fase I, 8,5\% na Fase II e 8,3\% para a Fase III. N última fase de operação do RALF (Fase IV) foi verificado o maior aumento percentual do pH efluente em relação ao afluente, de 10,3\%.

Por meio da análise dos valores verificados no afluente e efluente, é possível verificar que houve aumento da alcalinidade total efluente, em comparação ao afluente, levando a redução da relação AI/AP efluente.

O fenômeno de aumento da alcalinidade efluente em relação ao afluente no reator de leito fluidificado também foi verificado por por Motteran (2013) e (Braga, 2014). Esta configuração reacional (RALF) promove alta eficiência de degradação de compostos orgânicos 
formando $\mathrm{CO}_{2}$, o que associado a alta recirculação do efluente, permite a reintrodução deste $\mathrm{CO}_{2}$ na forma de $\mathrm{NaHCO}_{3}$, gerado pelo contato com o oxigênio atmosférico no separador de fases do RALF (SHIEH; KEENAN, 1986; IZA, 1991).

\subsubsection{Remoção de 4-Nonilfenol}

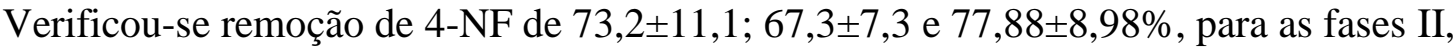
III e IV respectivamente. As concentrações médias de 4-NF afluente variaram de 127,4 $\pm 29,2$ a $376,1 \pm 35,8 \mu \mathrm{g} \mathrm{L}^{-1}$ para Fase II e IV, respectivamente. Os valores médios de 4-NF afluente, efluente, eficiência de remoção e comparação estatísticas das médias podem ser observados Tabela 5.19.

Tabela 5.19 - Valores médios de 4-NF Afluente, Efluente, Eficiência de Remoção e comparação estatísticas para as fases de operação do RALF.

\begin{tabular}{cccc}
\hline \multirow{2}{*}{ FASES } & \multicolumn{2}{c}{4 -Nonilfenol $\left(\mu \mathrm{g} \mathrm{L}^{-1}\right)$} & \multirow{2}{*}{ Eficiência (\%) } \\
\cline { 2 - 3 } & Afluente & Efluente & \\
\hline Fase II & $127,4 \pm 29,2 \mathrm{c}$ & $34,5 \pm 14,8 \mathrm{~b}$ & $73,2 \pm 11,1 \mathrm{ab}$ \\
Fase III & $270,1 \pm 24,7 \mathrm{~b}$ & $88,5 \pm 21,5 \mathrm{a}$ & $67,3 \pm 7,3 \mathrm{~b}$ \\
Fase IV & $376,1 \pm 35,8 \mathrm{a}$ & $82,72 \pm 33,8 \mathrm{ab}^{*}$ & $77,88 \pm 8,9 \mathrm{a}$ \\
\hline
\end{tabular}

* Médias seguidas da mesma letra não diferem pelo teste de Tukey, a $5 \%$ de probabilidade de erro.

A maior eficiência de remoção $(77,88 \pm 8,9 \%)$ de 4-NF ocorreu na Fase IV, para

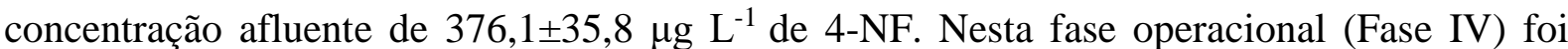
reduzida a concentração do co-substrato (etanol) da composição do meio de cultura (Tabela 4.2 e 4.3), o que pode ter favorecido na degradação do 4-NF. De acordo com Okada et al. (2014), a suplementação com co-substrato facilmente biodegradável a composição nutricional pode favorecer a colonização de consórcio degradador do composto de interesse e, uma vez adaptado, este consórcio pode consumir o contaminante mesmo na ausência do co-substrato (SANZ et al., 2003; DUARTE et al., 2010; MACEDO et al., 2015).

O aumento da concentração de 4-NF afluente da Fase III $\left(270,1 \pm 24,7 \mu \mathrm{g} \mathrm{L}^{-1}\right)$ para a Fase IV $\left(376,1 \pm 35,8 \mu \mathrm{g} \mathrm{L}^{-1}\right)$ não provocou aumento da concentração de 4-NF efluente de $88,5 \pm 21,5 \mu \mathrm{g} \mathrm{L}^{-1}$ (Fase III) para $82,72 \pm 33,8 \mu \mathrm{g} \mathrm{L} \mathrm{L}^{-1}$ (Fase IV), fazendo com que a maior 
concentração de 4-NF afluente $\left(376,1 \pm 35,8 \mu \mathrm{g} \mathrm{L}^{-1}\right)$ aplicada na Fase IV atingisse a maior eficiência de remoção $(77,88 \pm 8,9 \%)$. Este comportamento indica que o aumento da dose de 4NF proporcionou aumento da remoção deste composto.

Após 134 dias de operação, verificou-se estabilidade na concentração de 4-NF afluente $\left(273,89 \pm 18,87 \mu \mathrm{g} \mathrm{L}^{-1}\right)$, efluente $\left(96,84 \pm 13,49 \mu \mathrm{g} \mathrm{L} \mathrm{L}^{-1}\right)$ e eficiência de remoção $(64,6 \pm 4,7 \%)$, mantendo comportamento linear até o aumento da concentração de 4-NF afluente para 376,1 $\pm 35,8 \mu \mathrm{g} \mathrm{L}^{-1}$ (Fase IV). A variação temporal de 4-NF Afluente, Efluente e Eficiência de Remoção pode ser verificada no gráfico da Figura 5.26.

Figura 5.26 - Variação temporal de 4-Nonilfenol afluente, efluente e eficiência de remoção.

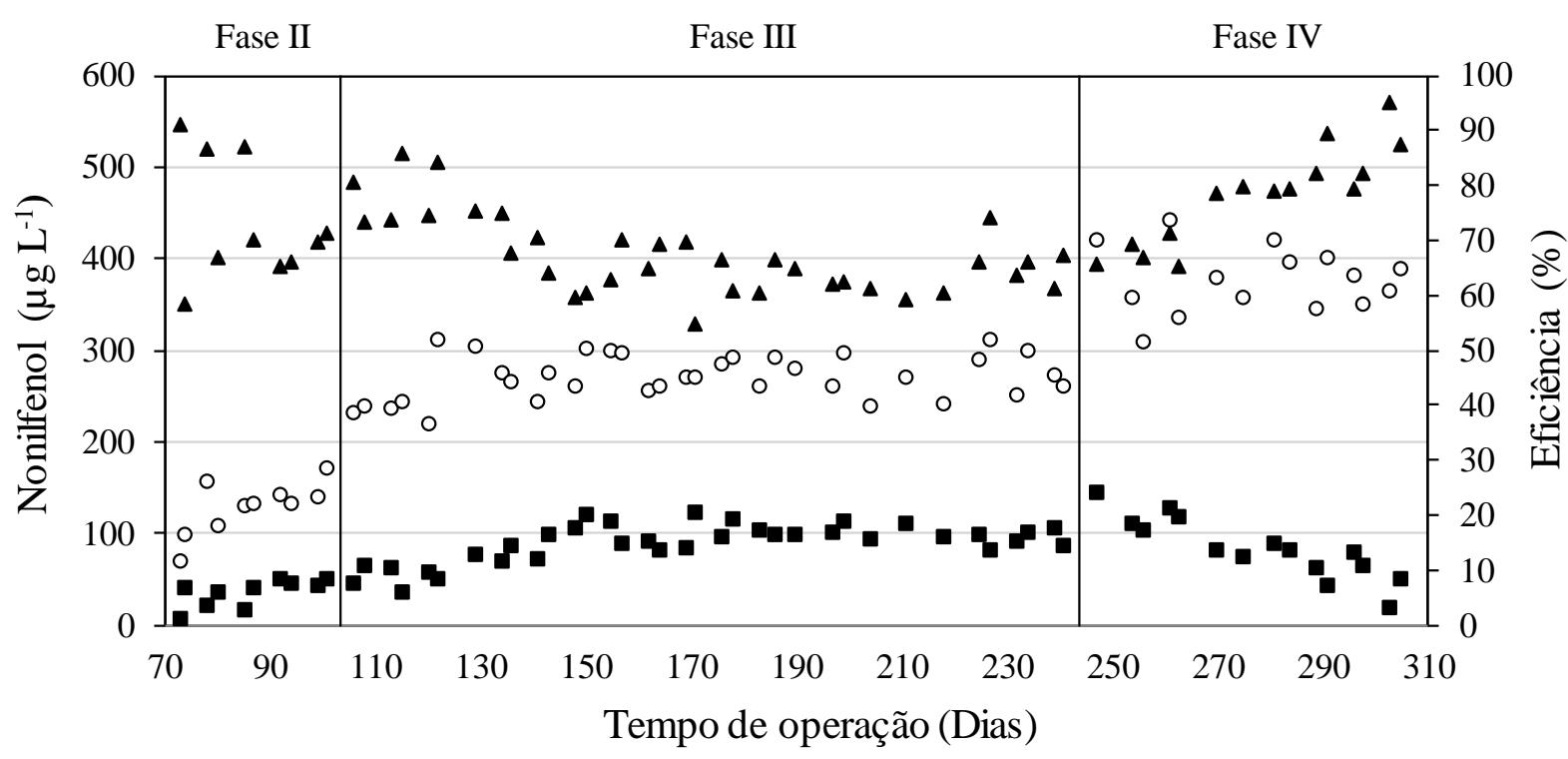

Fonte: $\mathrm{O}$ autor.

$\circ$ Afluente $\quad$ Efluente $\Delta$ Eficiência

Gao et al. (2014) avaliaram a degradação de NFe em estação de tratamento de esgoto em escala real, em sistema anaeróbio/aeróbio, composto por tanque anaeróbio seguido de filtro biológico aerado e operados com TDH de 10 horas. A eficiência de remoção após o tanque anaeróbio foi de $39 \%$ para afluente de 1,8 a $2 \mu \mathrm{g} \mathrm{L^{-1 }}$. Após o filtro aeróbio a eficiência de remoção foi de 78\%, próximo as eficiências verificadas neste trabalho (67 a 78\%). Apesar das configurações reacionais extremante diferentes do presente trabalho, os dados descritos por Gao et al. (2014) indicam a viabilidade da aplicação de processos biológico para remoção de micropoluentes como o 4-NF.

O aumento da concentração de 4-NF afluente da Fase II $\left(127,4 \pm 29,2 \mu \mathrm{g} \mathrm{L}^{-1}\right)$ para a Fase III $\left(270,1 \pm 24,7 \mu \mathrm{g} \mathrm{L}^{-1}\right)$ ocasionou aumento da concentração de 4-NF efluente de 34,5 $\pm 14,8 \mu \mathrm{g}$ $\mathrm{L}^{-1}$ (Fase II) para 88,5 $\pm 21,5 \mu \mathrm{g} \mathrm{L}{ }^{-1}$ (Fase III). Todavia, não verificou-se diferença significativa 
entre as eficiências de remoção de 4-NF para estas fases $(73,2 \pm 11,1 \%$ para Fase II e $67,3 \pm 7,3 \%$ para Fase III). O comportamento do 4-NF afluente, efluente e eficiência de remoção pode ser verificado na Figura 5.27.

Figura 5.27 - Representação em box-plot para 4-NF afluente, efluente e eficiência de remoção para as fases operacionais do RALF.
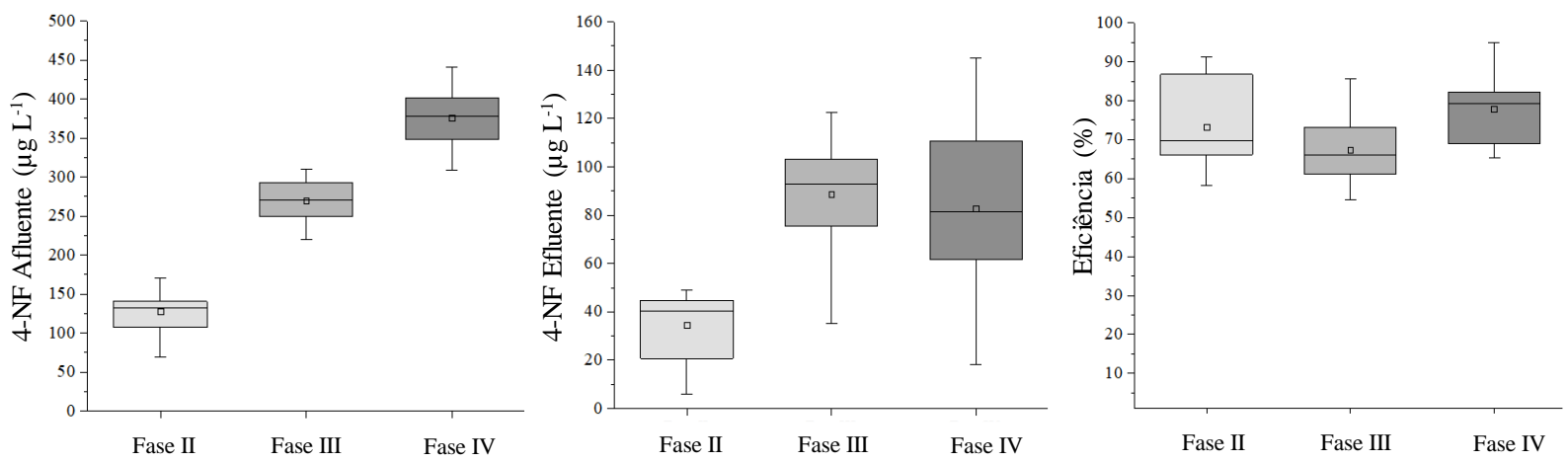

Fonte: $\mathrm{O}$ autor.

Fujita et al. (2000) avaliaram a comportamento de Nonilfenol Etoxilado (NFe) em 40 estações de tratamento de esgoto em escala real do Japão, em sistemas de lodos ativados ${ }^{23}$ e verificaram eficiências de remoção de cerca de $60 \%$, para afluente médio de $296 \mu \mathrm{g} \mathrm{L}{ }^{-1}$ de 4 NF.

Zhang et al. (2008) avaliaram a remoção do surfactante Nonilfenol Etoxilado (NFe) em reator anaeróbio de manta de lodo (UASB) em escala de bancada (4 L), alimentado continuamente com esgoto doméstico e TDHs de 5,5, 8,7 e 15,8 h; a dosagem de NFe era feita a cada $12 \mathrm{~h}$ em picos de $15 \mathrm{mg} \mathrm{L}^{-1}$. Houve aumento da eficiência de remoção com o aumento do TDH, atingindo cerca de $92 \%$ para um TDH de $15,8 \mathrm{~h}$. No presente trabalho foi verificada eficiência máxima de $77,88 \pm 8,9 \%$ para um $\mathrm{TDH}$ de $18 \mathrm{~h}$, inferior a relatada por Zhang et al. (2008), contudo, os autores não avaliaram a fração adsorvida a manta de lodo do reator UASB e a eficiência de remoção (92\%) pode ter sio superestimada pelo fenômeno de adsorção. Deste modo, a maior eficiência de remoção verificada por Zhang et al. (2008) pode estar relacionado a configuração reacional usada, uma vez que o reator UASB possui expessa manta de lodo

\footnotetext{
${ }^{23}$ As estações de tratamento de esgoto em escala real monitoradas por Fujita et al. (2000) consistiram em: clarificadores primários, tanques de aeração, clarificadores secundários e processos de desinfecção, com algumas exceções que não possuem processos de desinfecção. A maioria das ETEs eram operadas como processos convencionais de lodos ativados. As ETEs recebiam principalmente águas residuária domésticas e algumas recebiam águas residuária industriais.
} 
(potencializando a adsorção) enquanto que o reator RALF possui sua biomassa imobilizada na forma de tênue biofilme.

\subsubsection{Balanço de massa}

O 4-Nonilfenol adsorvido ao material suporte (areia) foi quantificado ao final de cada

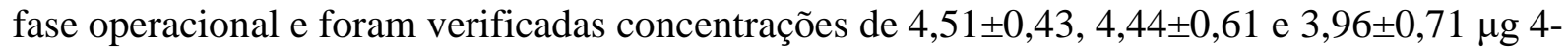
$\mathrm{NF} \mathrm{g}^{-1}$ de areia, para as Fases II, III e IV, respectivamente. Por meio do teste de Tukey (a 5\% de probabilidade de erro) não foi verificada diferença significativa entre os valores.

Em relação ao balanço de massa global de 4-Nonilfenol no RALF, foram adicionados 1,6 g de 4-NF em 233 dias de operação; sendo recuperados 0,468 g de 4-NF efluente e 0,019 g de 4-NF adsorvidos no material suporte (areia) ao final da última fase de operação (Fase IV), o que representou cerca de $1 \%$ do 4-NF total adicionado. Na Figura 5.28 estão representadas a distribuição percentual do 4-NF adsorvido na areia, recuperado no efluente e degradação.

Figura 5.28 - Distribuição percentual do balanço de massa de 4-Nonilfenol.

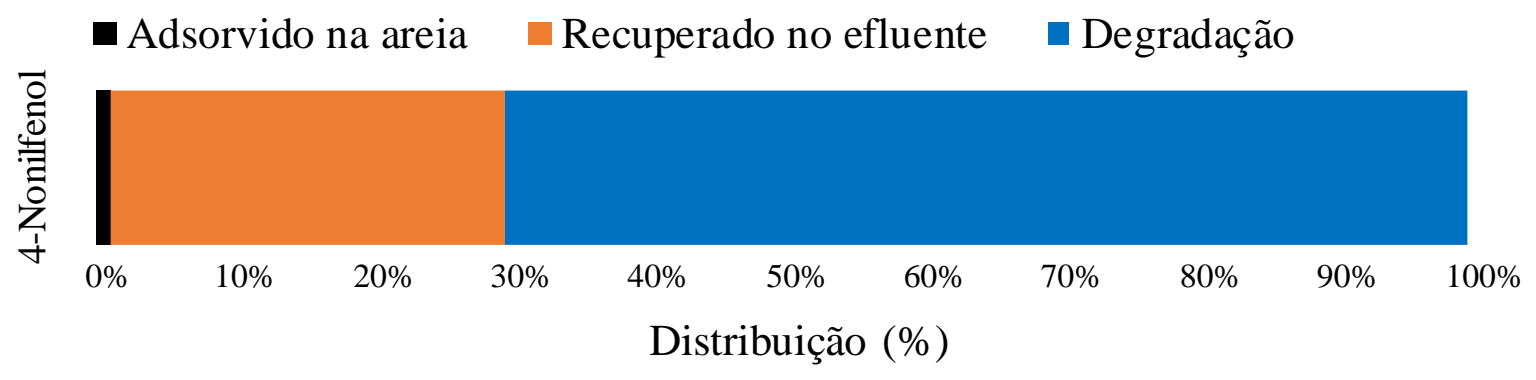

Fonte: $\mathrm{O}$ autor.

Gao et al. (2014) avaliaram a ocorrênica de NFe em estação de tratamento de esgoto em escala real e verificaram valores afluentes de 1,8 a $2,0 \mu \mathrm{g} \mathrm{L}^{-1}$ enquanto que no lodo foram verificados valores de $2,7 \mu \mathrm{g} \mathrm{g}^{-1}$ de lodo. As maiores concentrações de 4-NF adsorvidas ao material suporte verificadas no presente trabalho $\left(3,9\right.$ a $4,5 \mu \mathrm{g} \mathrm{g}^{-1}$ de areia) podem estar relacionadas a maiores concentrações afluente $\left(127,4 \pm 29,2\right.$ a $\left.376,1 \pm 35,8 \mu \mathrm{g} \mathrm{L}^{-1}\right)$.

A concentração de 4-NF adsorvido a massa total de material suporte (4.500 g de areia) ao final de cada fase operacional foi de 20.295, 19.995 e $17.800 \mu \mathrm{g}$, para a Fase II, III e IV, respectivamente. Por meio do teste de Tukey a 5\% de probabilidade de erro não foi verificada diferença significativa. Avaliando a distribuição percentual de 4-NF (adsorvido, biodegradado e recuperado no efluente) em cada fase operacional, a fração correspondente ao 4-NF adsorvido 
(em $4.500 \mathrm{~g}$ de areia) representou cerca de $22 \%$ na Fase II, $2 \%$ na Fase III e $3 \%$ na Fase IV (Figura 5.29)

Figura 5.29 - Distribuição percentual do balanço de massa em cada fase operacional e carga diária de 4-NF aplicada.

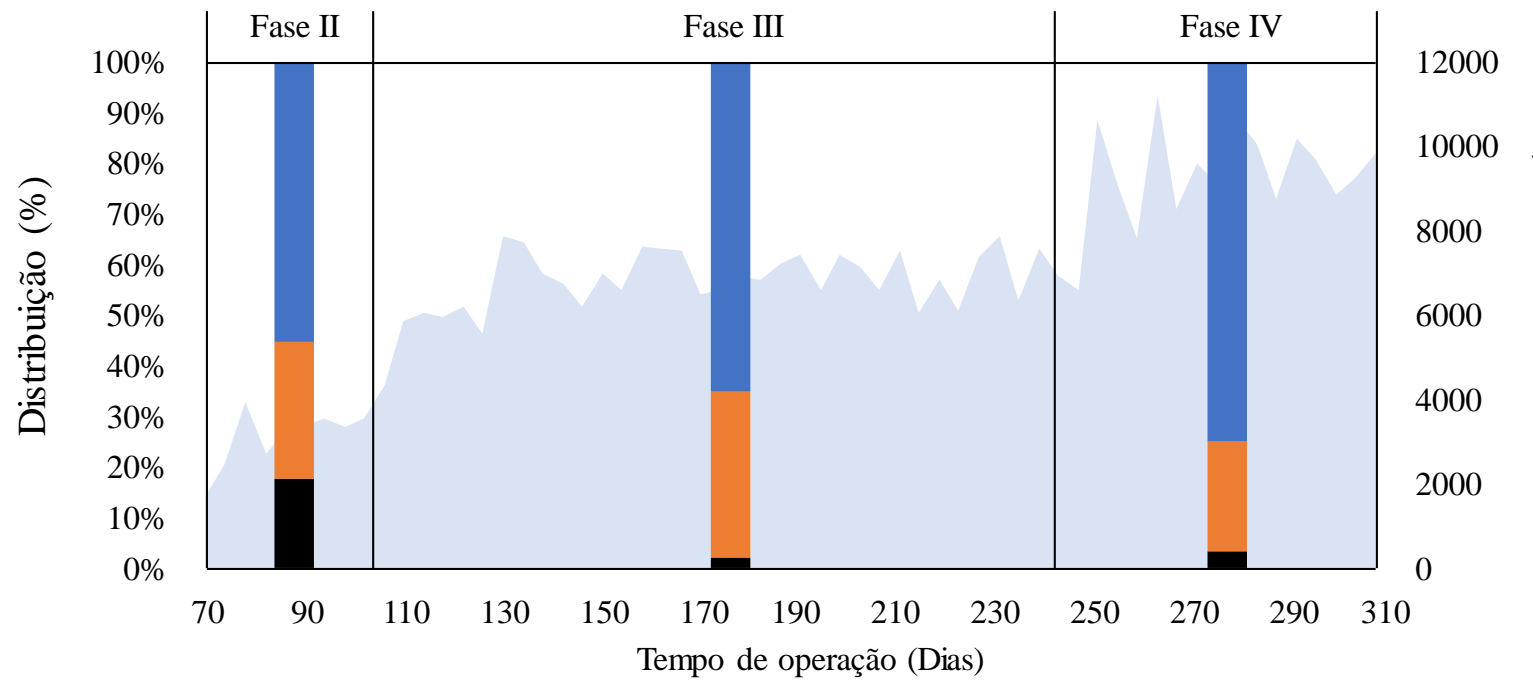

Carga aplicada

Adsorvido Recuperado no Efluente

Biodegradado

Fonte: O autor.

Verificou-se nesta pesquisa que o aumento de carga aplicada de 4-NF não implicou em aumento da concentração de 4-NF adsorvido. Provavelmente, os sítios de adsorção do material suporte foram completamente saturados logo na primeira fase operacional.

Na primeira fase com adição de 4-NF (Fase II) verificou-se o maior percentual de 4-NF adsorvido (22\%) em comparação com as Fases III (2\%) e IV (3\%). Isso aconteceu devido a menor carga de 4-NF aplicada na fase II $(0,1 \mathrm{mg})$, indicando que a concentração de 4-NF adsorvido ao material suporte (areia) não aumentou de forma proporcional ao aumento de carga. Uma vez que os sítios de adsorção do material suporte foram saturados, o aumento da carga de 4-NF aplicada na Fase III $\left(6870 \pm 628 \mu \mathrm{g} \mathrm{d}^{-1}\right)$ e IV $\left(9568 \pm 910 \mu \mathrm{g} \mathrm{d}^{-1}\right)$ proporcionou aumento da concentração de 4-NF efluente e degradado

Braga et al. (2015) avaliaram a biodegradação de surfactante aniônico LAS em RALF em escala de bancada (1,27 L), em TDH de 18 a $23 \mathrm{~h}$, usando areia como material suporte e verificaram adsorção de 1,6\%, próximo aos valores encontrados neste trabalho (1\%). A baixa adsorção percentual do composto a areia pode ter ocorrido devido as características deste material suporte. Oliveira et al. (2010) avaliaram a aplicação de diferentes materiais suporte em 
reator de leito fluidificado RALF para a degradação de surfactante aniônico (LAS) e verificaram valores de LAS adsorvido de $34 \mathrm{mg}, 0 \mathrm{mg}, 0,81 \mathrm{mg}$ e 0,92 mg para carvão ativado, argila expandida, pérolas de vidro e areia, respectivamente.

\subsubsection{Biomassa aderida ao material suporte}

Neste trabalho observou-se 2,46 $\pm 0,30 \mathrm{mg} \mathrm{STV} \mathrm{g}^{-1}$ de areia (Tabela 5.20). Por meio do teste de Tukey não foi verificada diferença significativa entre as médias, todavia, com tendência de aumento da concentração de STV com o aumento do tempo de operação do RALF (Figura 5.30).

Tabela 5.20 - Valores de Sólidos Totais Voláteis (STV) do material suporte (areia) para as fases de operação do RALF.

\begin{tabular}{cc}
\hline Fases & STV $\left(\mathrm{mg} \mathrm{g}^{-1}\right.$ de areia $)$ \\
\hline Fase I & $2,19 \pm 0,30 \mathrm{a}$ \\
Fase II & $2,27 \pm 0,04 \mathrm{a}^{*}$ \\
Fase III & $2,54 \pm 0,11 \mathrm{a}$ \\
Fase IV & $2,85 \pm 0,71 \mathrm{a}$ \\
\hline
\end{tabular}

* Médias seguidas da mesma letra não diferem pelo teste de Tukey, a 5\% de probabilidade de erro.

Figura 5.30 - Valores médios de Sólidos Totais Voláteis (STV) do material suporte (areia) para as fases de operação do RALF.

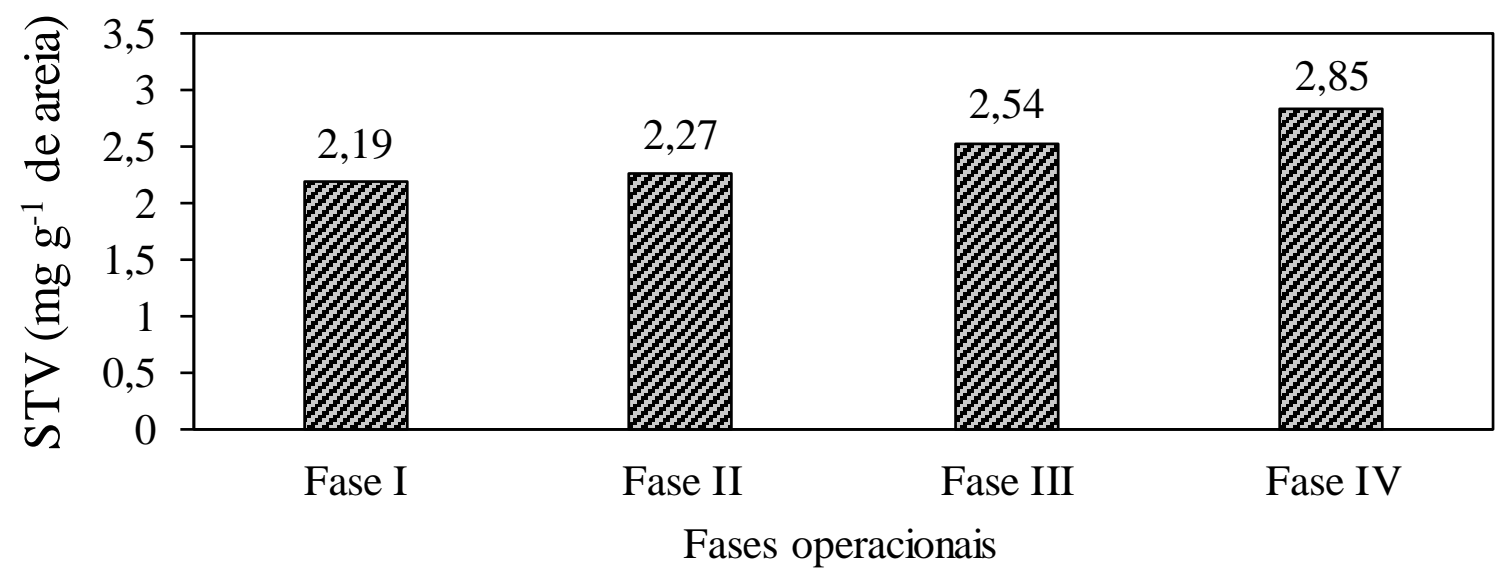

Fonte: $\mathrm{O}$ autor. 
A concentração de biomassa em reatores tende a aumentar ao decorrer do período operacional, excetuando casos onde ocorre a inibição do processo biológico por deficiências nutricionais do meio, inserção de compostos tóxicos, sobrecarga afluente ou variação brusca de temperatura, por exemplo (SHIEH; MULCAHY; LAMOTTA, 1982; HENZE; HARREMOES, 1983; SPEECE, 1983; IZA, 1991; METCALF; EDDY, 2003).

\subsubsection{Exames microscópicos}

Ao final da Fase II de operação do reator foram retiradas amostras de areia do leito do reator para a realização de Microscopia Eletrônica de Varredura (MEV), afim de verificar a diversidade morfológica dos microrganismos aderidos ao meio suporte. Para verificar a rugosidade do material suporte foi realizada MEV do grão de areia isento de biofilme, como pode ser visto na Figura 5.31.

Figura 5.31 - Microscopia eletrônica de varredura do grão de areia isento de biofilme (aumento $150 \mathrm{X})$.

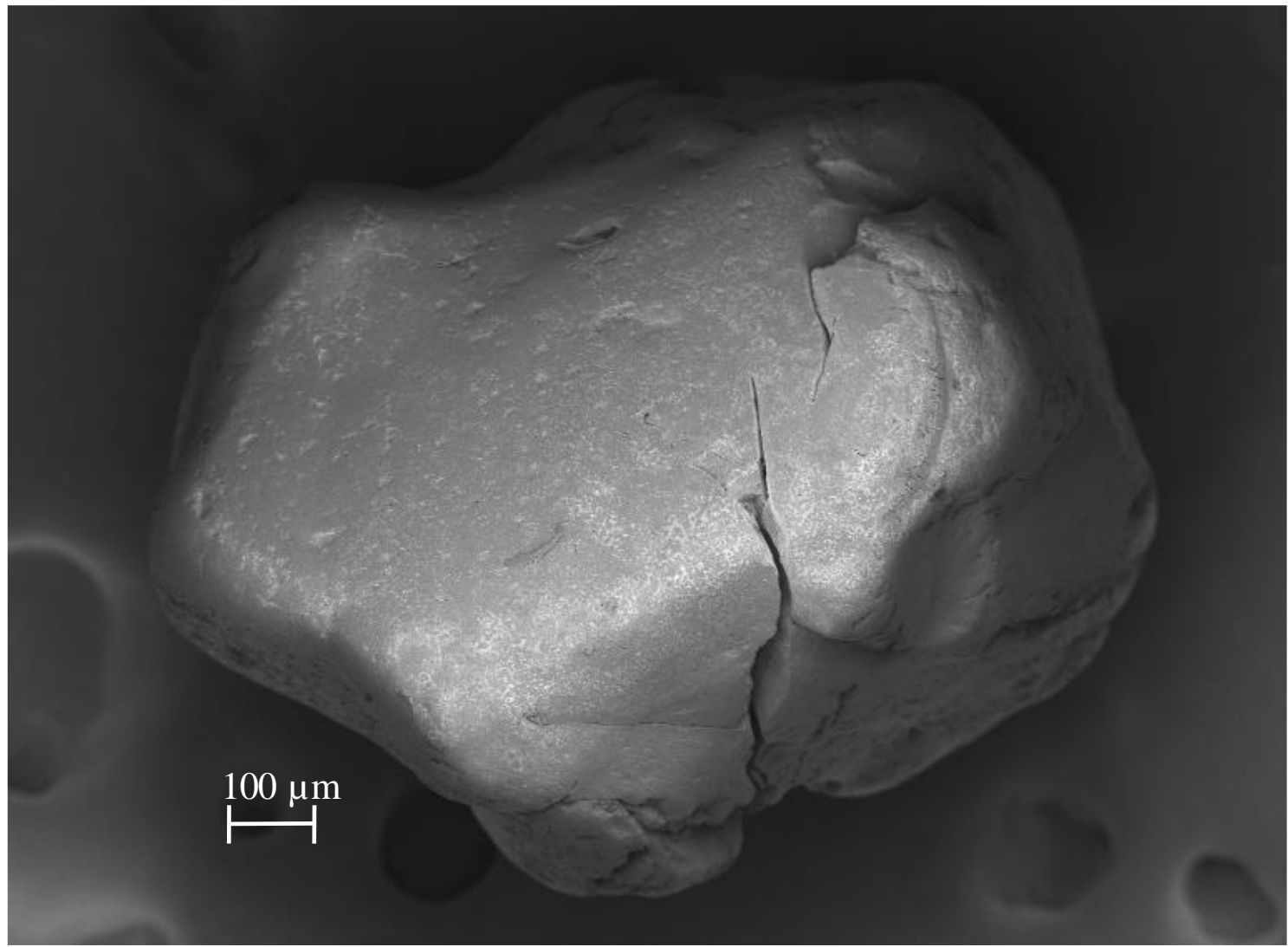

Fonte: $\mathrm{O}$ autor. 
Comparação por MEV também foi feita para areia isenta de biofilme e aquela retirada do leito do reator após 102 dias contínuos (Fase II) de operação (Figura 5.32). No detalhe das imagens (B1) é possível verificar o preenchimento das microvilosidades com biofilme microbiano.

Figura 5.32 - Microscopia eletrônica de varredura da areia isenta de biofilme (A) (aumento 1000X) com detalhe para as microvilosidades da superfície (A1); e areia retirada do leito do reator (B) (aumento 1000X) após 102 dias de operação (Fase II), com detalhe para microvilosidade preenchida com biofilme (B1).
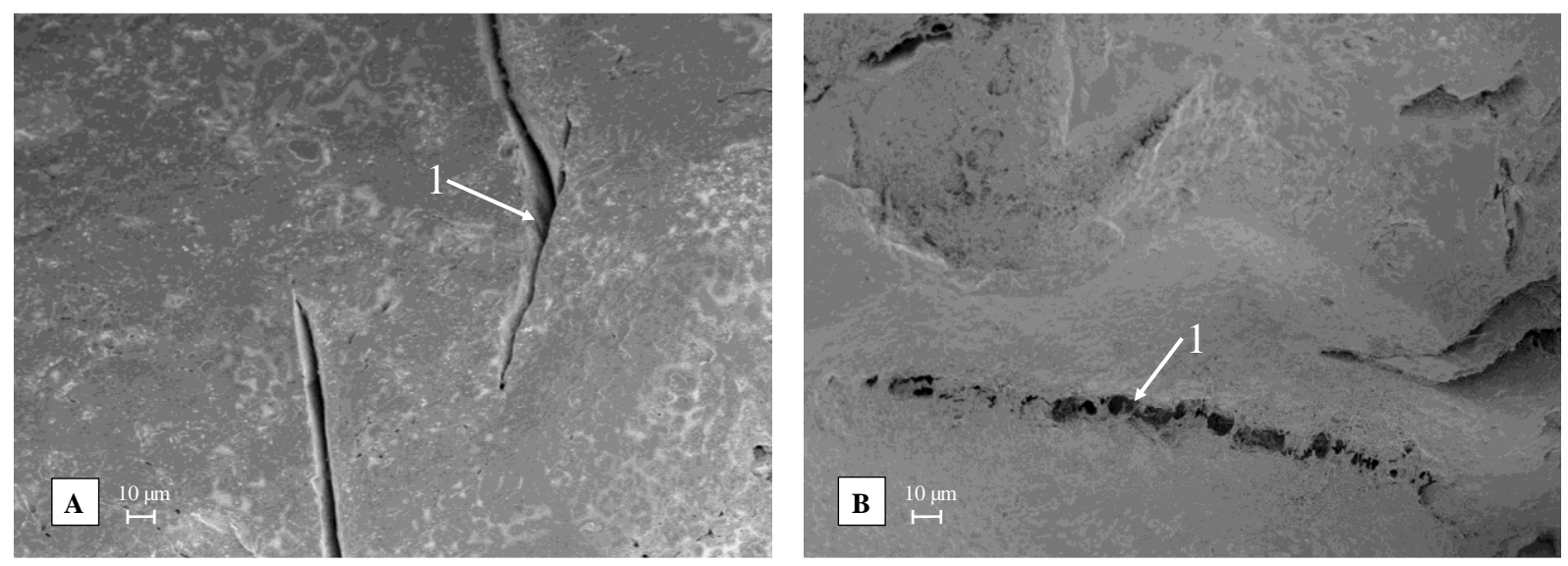

Fonte: $\mathrm{O}$ autor.

Na parte externa da areia observou-se a predominância de bacilos e cocobacilos de diversos tamanhos. Também pôde-se observar a adequada superfície de fixação promovida pelo material suporte (areia), cujas microvilosidades foram obtidas pelo tratamento com ácido fluorídrico, possibilitando assim maior área superficial para a formação do biofilme. As morfologias microbianas que compuseram o biofilme podem ser observadas na Figura 5.33.

$\mathrm{Na}$ parte interna das microvilosidades observou-se morfologia diferente, quando comparada aquelas da parte externa. $\mathrm{Na}$ parte interna foram verificados microrganismos agrupados na forma de feixes em paliçada. Esse arranjo é característico do gênero Methanosaeta (BUZZINI et al., 2006). A MEV da parte interna da microvilosidade da areia pode ser observada na Figura 5.34. 
Figura 5.33 - Microscopia eletrônica de varredura dos microrganismos observados na areia do leito do reator após 102 dias de operação (aumento 5.000X). (1) bacilos; (2) cocobacilos.

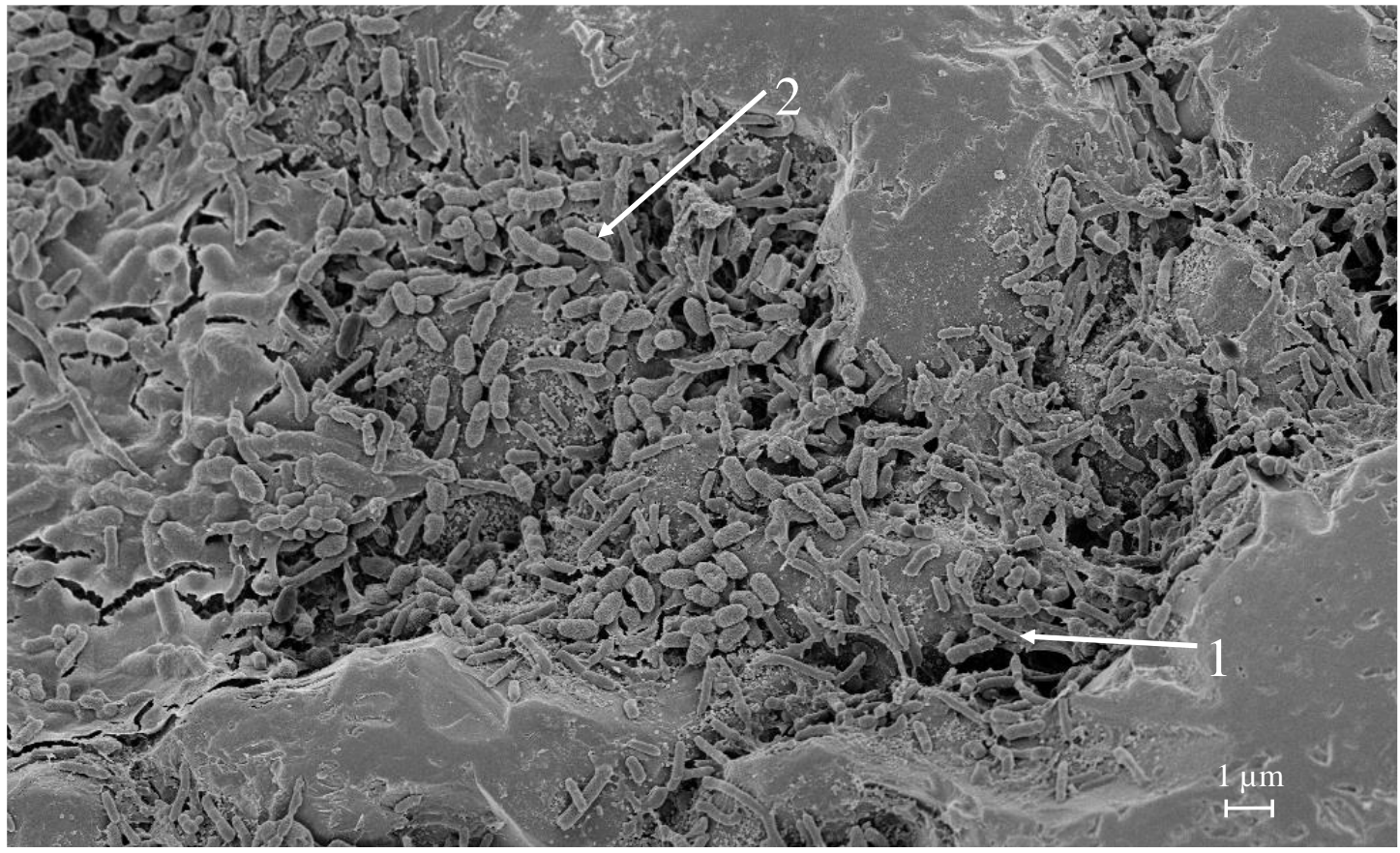

Fonte: $\mathrm{O}$ autor.

Figura 5.34 - Microscopia eletrônica de varredura das vilosidades da areia do leito do reator após 102 dias de operação (aumento 10.000X) com arranjo microbiano em feixe.

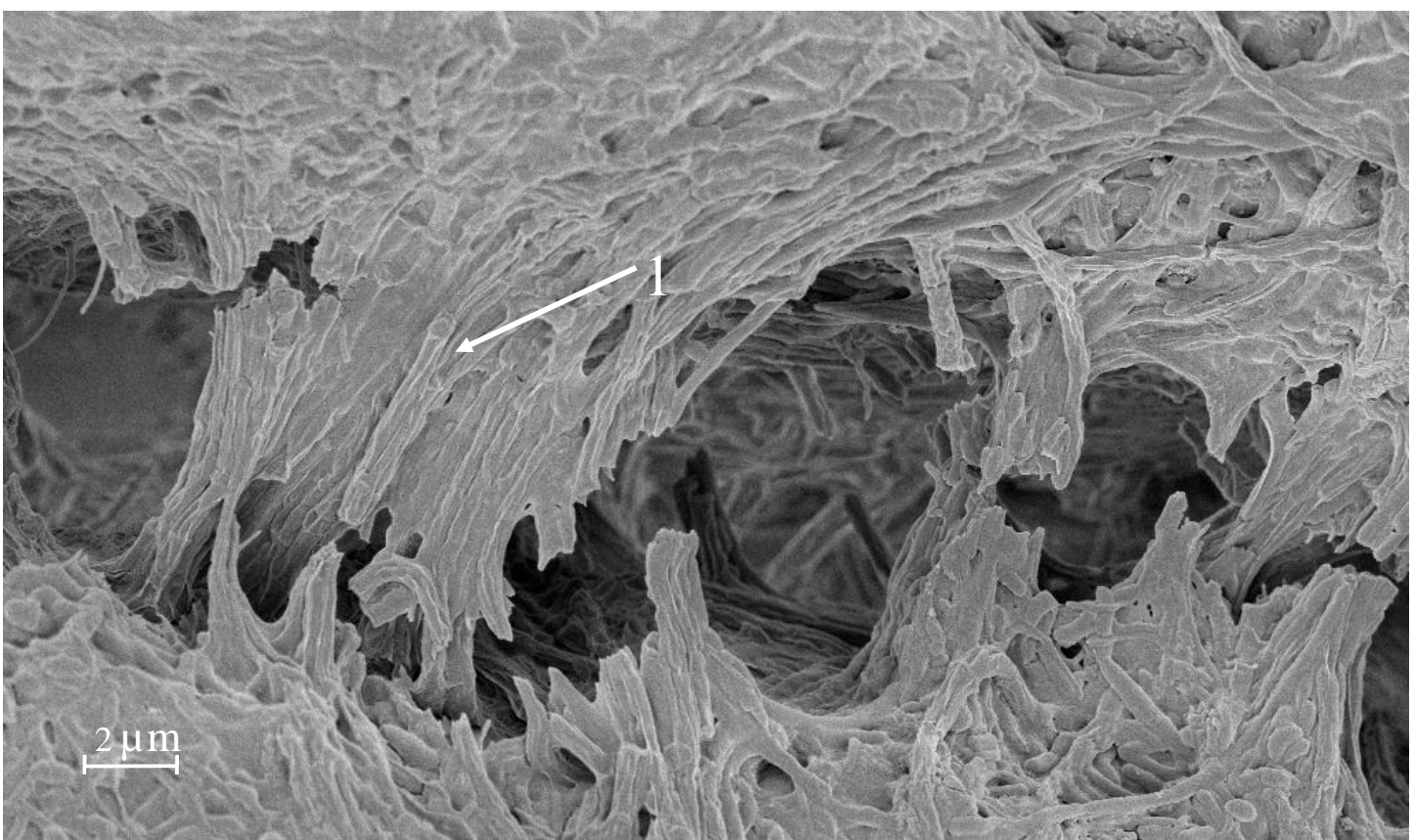

Fonte: $\mathrm{O}$ autor. 
Durante a operação do reator ocorreu a formação de um leito granular sobre o leito de areia, como visualizado na Figura 5.35.

Figura 5.35 - Fotografias do leito do RALF: (A) anterior a sua inoculação; (B) após 102 dias de operação; (B1) leito granular formado sobre o leito de areia.
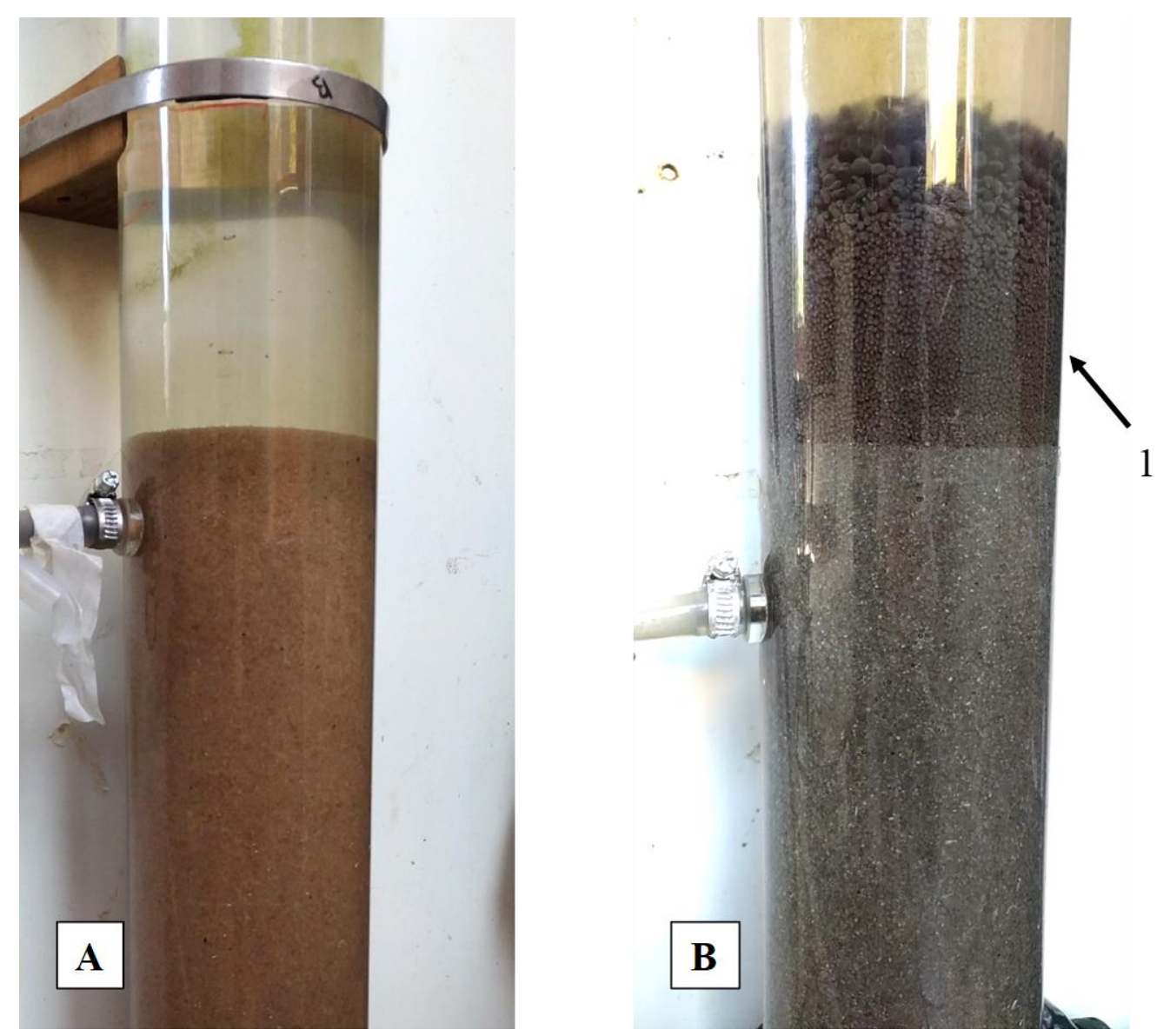

Fonte: $\mathrm{O}$ autor.

Foram coletadas amostras deste leito e os grânulos foram pré-tratados afim de realizar a MEV. Os grânulos foram recortados e dispostos de forma que seu interior pudesse ser observado. A MEV de um dos grânulos recortados pode ser verificada na Figura 5.36.

Verificou-se total recobrimento do grão de areia por biofilme espesso. Cada grânulo coletado apresentava em seu interior um grão de areia. Esse biofilme apresentou em sua constituição morfológica aglomerado celular e predomínio de exopolímeros (Figura 5.37). 
Figura 5.36 - Microscopia eletrônica de um grão de areia coberto por biofilme (aumento 150X), retirado do leito granular do RALF após 102 dias de operação.

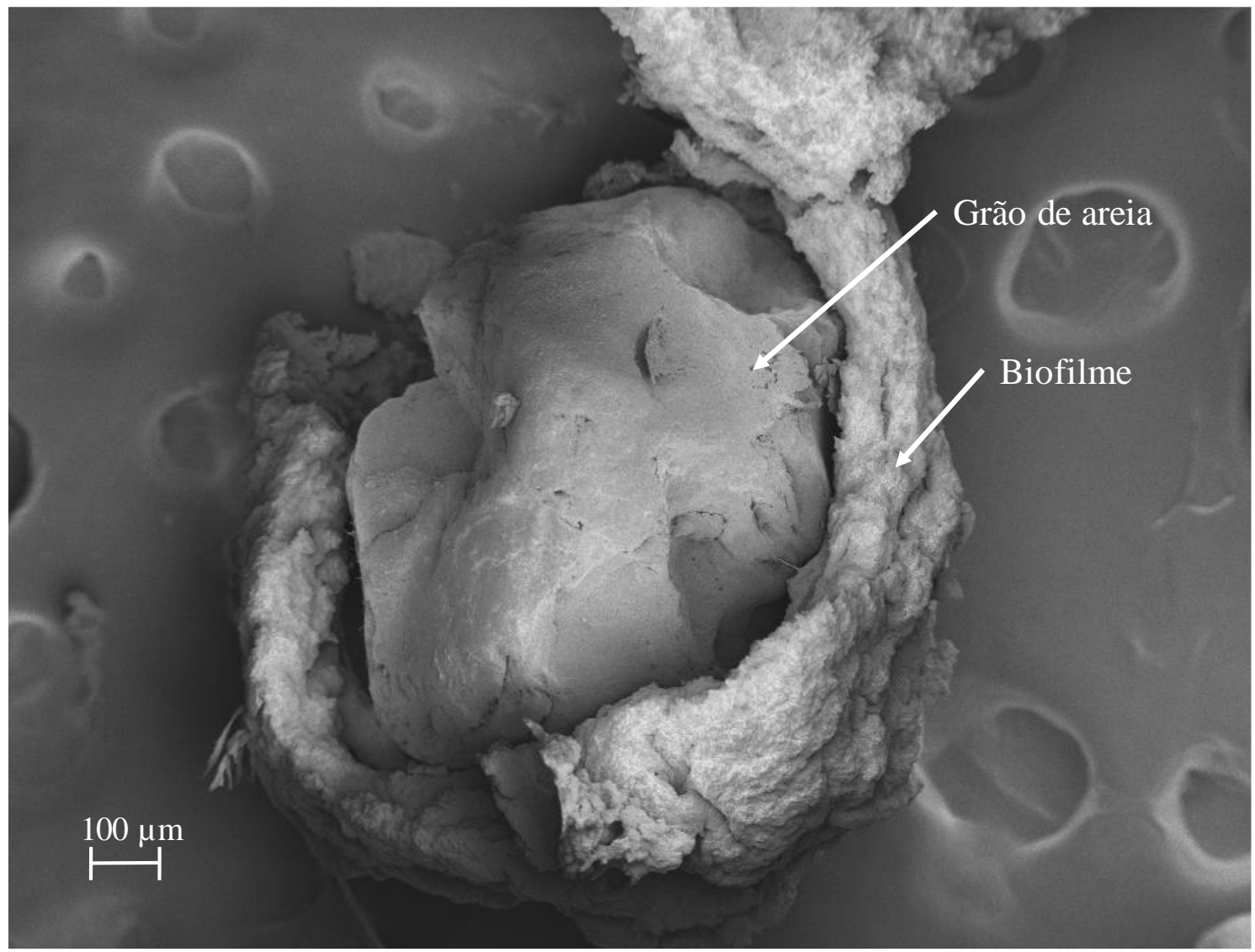

Fonte: $\mathrm{O}$ autor.

Figura 5.37 - Microscopia eletrônica de varredura do biofilme do grânulo: (A1) aglomerado celular do interior do biofilme (aumento 5.000X); (B1) aglomerado celular coberto por exopolímero; (B2) exopolímero.
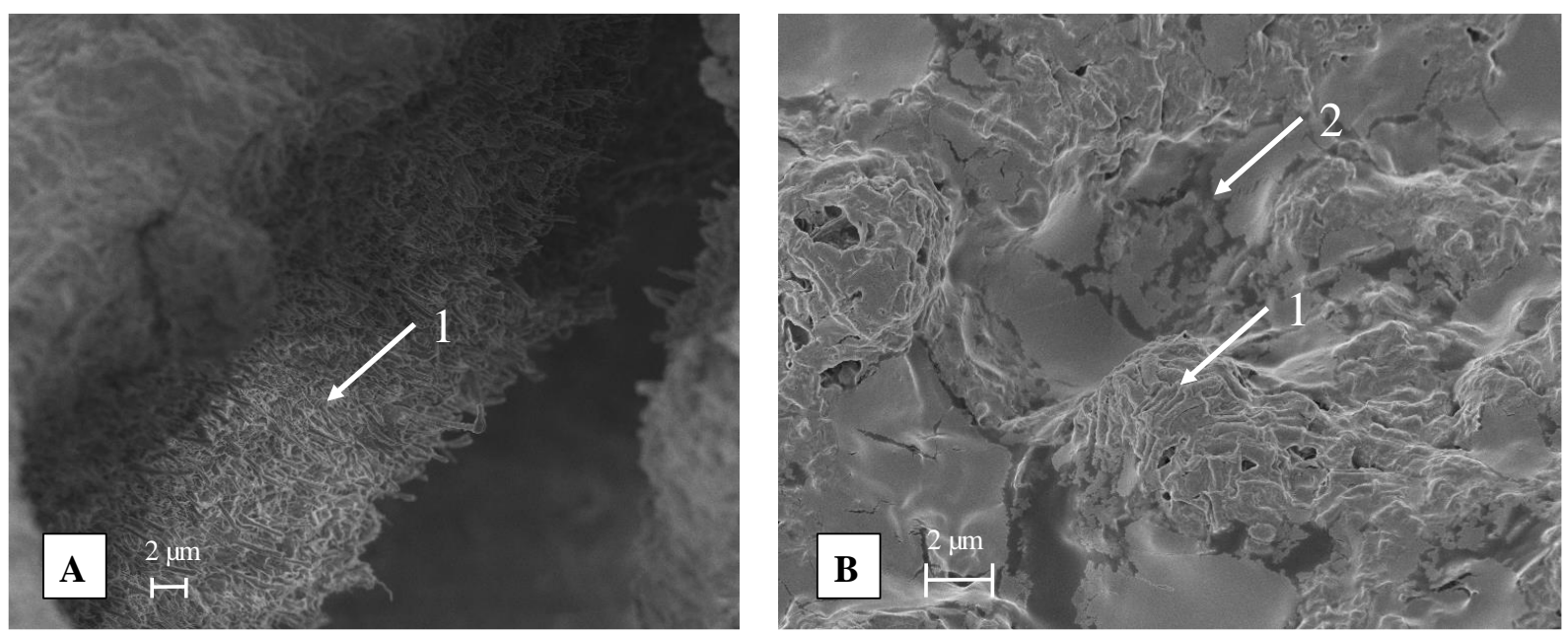

Fonte: $\mathrm{O}$ autor. 


\subsubsection{Eletroforese em Gel com Gradiente Desnaturante (DGGE)}

Foram analisadas amostras do leito de areia do RALF para as fases de Adaptação, Fase I, II, III e IV. Por meio da análise do perfil de bandas do DGGE observou-se mudanças nas populações microbianas para os Domínios Archaea e Bacteria.

\subsubsection{Domínio Bacteria}

Mediante análise de cluster do perfil das bandas padrões do DGGE para o domínio Bacteria, foram verificadas mudanças nas comunidades microbianas estabelecidas no leito de areia. A menor similaridade (10\%) foi verificada entre o inóculo e as demais fases operacionais do reator. O inóculo usado neste trabalho foi proveniente de reator UASB do tratamento de efluentes de abatedouro de aves (DEL NERY et al., 2016). A baixa similaridade pode ter ocorrido devido a mudança da configuração reacional e composição nutricional do substrato, por conseguinte, mudança brusca no perfil de populações de bactérias.

A adição de 4-NF provocou mudanças na composição da comunidade microbiana do RALF, expressa pela baixa similaridade (25\%) entre a fase sem adição de 4-NF (Fase I) e as fases com adição de 4-NF (Fases II, III e IV). Os percentuais de similaridade para o domínio Bacteria para cada fase de operação do RALF podem ser verificados no dendograma da Figura 5.38 .

Figura 5.38 - Análise de cluster (Correlação de Pearson, UPGMA) do perfil das bandas do DGGE dos fragmentos do RNAr 16S para o Domínio Bacteria de amostras do Inóculo, Fase I, II, III e IV do RALF.

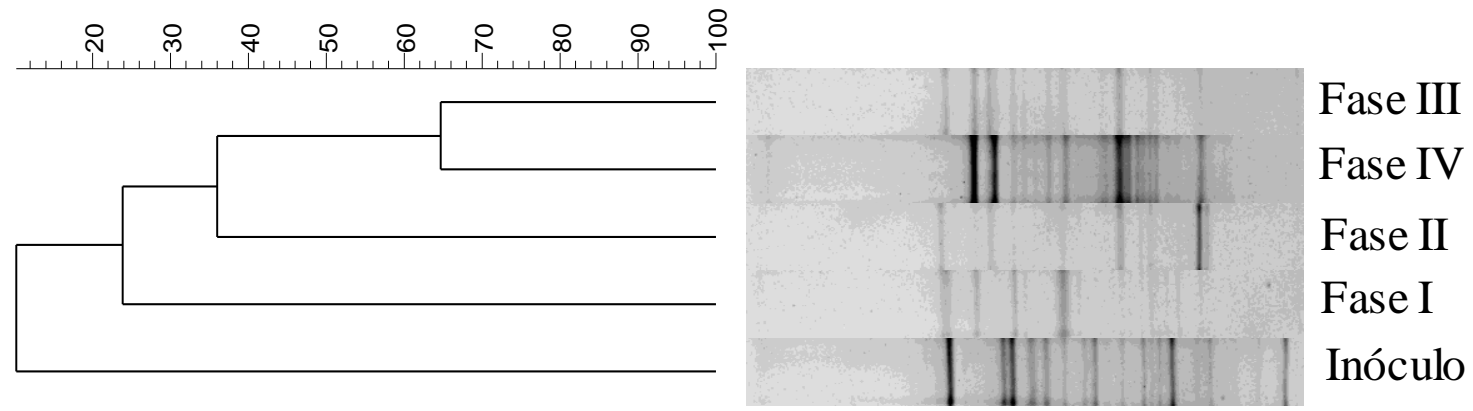

Fonte: $\mathrm{O}$ autor. 


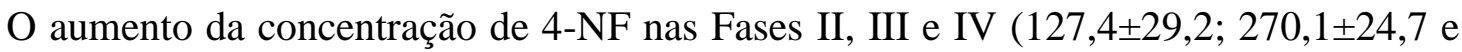
$376,1 \pm 35,8 \mu \mathrm{g} \mathrm{L}^{-1}$, respectivamente) provocou aumento da similaridade (de 35 para 65\%), indicando que adição do composto tóxico provocou a seleção de microrganismos estabelecidos no biofilme. Desse modo, observou-se a maior similaridade (65\%) entre as populações das Fases III e IV. Nessas fases foram aplicadas $270,1 \pm 24,7$ e $376,1 \pm 35,8 \mu \mathrm{g} \mathrm{L}^{-1}$, respectivamente de 4-NF. Provavelmente, a maioria das populações da fase III estava adaptada às condições com 4-NF e, mesmo com aumento da concentração, algumas populações mantiveram-se nas condições impostas à fase IV.

Em relação aos índices de diversidade, verificou-se os maiores valores de diversidade $(2,74)$ e riqueza (22) para a amostra de Inóculo, resultando também na menor dominância $(0,08512)$. Foi verificada redução da riqueza (Chao-1) e diversidade (Shannon) após a adição de 4-NF ao reator referente a Fase II, em comparação a fase sem adição de 4-NF (Fase I). Para as condições da Fase II, com menor concentração de 4-NF $\left(127,4 \pm 29,2 \mu \mathrm{g} \mathrm{L}^{-1}\right)$ observou-se os menores índices de riqueza (Chao-1), diversidade (Shannon) e equitabilidade (Pielou), em comparação as demais fases operacionais. Provavelmente, ocorreu supressão de populações de bactérias após o contato com o 4-NF (Fase II), o que justifica a menor diversidade $(2,14)$ e a maior dominância $(0,1665)$. Os valores referentes aos índices de diversidade para o Domínio Bacteria em todas as fases de operação do RALF podem ser verificados na Tabela 5.21.

Tabela 5.21 - Índices de diversidade para o Domínio Bacteria em todas as fases de operação do RALF.

\begin{tabular}{lccccc}
\hline \multicolumn{1}{c}{ Índice } & Inóculo & Fase I & Fase II & Fase III & Fase IV \\
\hline Dominância & 0,08512 & 0,1084 & 0,1665 & 0,1014 & 0,1051 \\
Diversidade & 2,74 & 2,42 & 2,14 & 2,42 & 2,53 \\
Equitabilidade & 0,8863 & 0,9171 & 0,8618 & 0,9414 & 0,8735 \\
Riqueza & 22 & 14 & 12 & 13 & 18 \\
\hline
\end{tabular}

A maior diversidade (Shannon) para o domínio Bacteria ocorreu para a amostra do inóculo. A redução da diversidade da Fase I, em comparação ao Inóculo, pode estar relacionada a configuração reacional e composição nutricional do meio, uma vez que o inóculo (proveniente de reator UASB) estava adaptado a água residuária de avicultura, rica em compostos orgânicos de fácil degradação; ou seja, meio complexo nutricionalmente favorável a suprir diversidade 
maior de populações. A Figura 5.39 ilustra a tendência de variação dos índices de riqueza e diversidade para o domínio Bacteria nas fases operacionais do RALF e no Inóculo.

Figura 5.39 - Variação dos Índices de diversidade e riqueza para o Domínio Bacteria em todas as fases de operação do RALF.

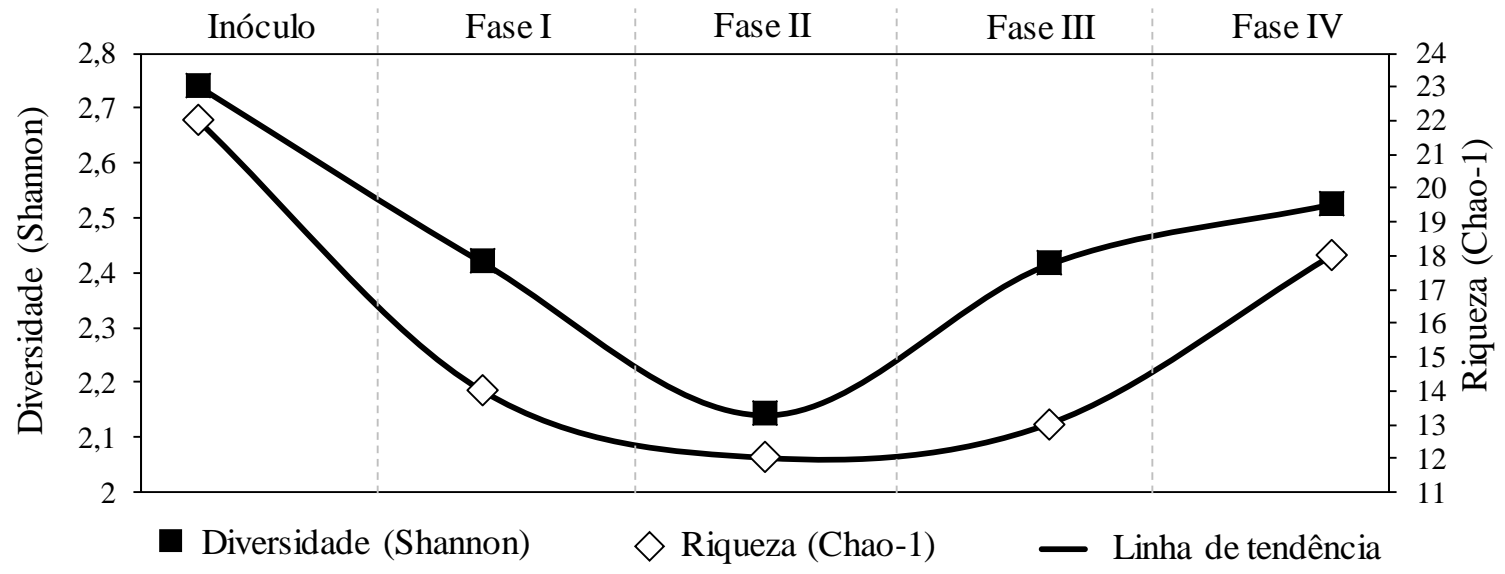

Fonte: $\mathrm{O}$ autor.

Para as fases operacionais do RALF (Fase I, II, III e IV) foi verificada redução da diversidade e riqueza imediatamente após adição de 4-NF (Fase II) em comparação a fase controle (Fase I). Provavelmente, esta redução pode estar relacionada a inibição das populações estabelecidas na fase sem adição de 4-NF (Fase I), uma vez que esta não estava adaptada a este composto e foram eliminadas nas condições impostas da Fase II. Entretanto, o aumento da concentração de 4-NF para $270,1 \pm 24,7 \mu \mathrm{g} \mathrm{L} \mathrm{L}^{-1}$ e $376,1 \pm 35,8 \mu \mathrm{g} \mathrm{L}^{-1}$ na Fase III e IV, respectivamente, favoreceu aumento da diversidade em relação as condições da Fase I (controle sem 4-NF), sugerindo adaptação das populações ao 4-NF.

Zhang et al. (2008) avaliaram a remoção do surfactante Nonilfenol etoxilado (NFe) (adicionado em picos de $15 \mathrm{mg} \mathrm{L}^{-1}$ a cada 12h) em reator anaeróbio de manta de lodo (UASB) em escala de bancada (4 L), alimentado continuamente com esgoto doméstico em TDH de 5,5, 8,7 e $15,8 \mathrm{~h}$. Os autores avaliaram a comunidade microbiana por meio do perfil de bandas do DGGE para o domínio Bacteria e constataram que a adição de NFe ocasionou a seleção de microrganismos capazes de degradas este composto.

Observou-se maior riqueza e diversidade de populações para a maior concentração de 4-NF (Fase IV), em comparação com a fases operacionais do RALF com menor concentração (Fase II e III). Provavelmente, ocorreu adaptação das populações capazes de metabolizar o 4NF e consequente aumento destas no meio reacional. A menor diversidade $(2,14)$ verificada imediatamente após a fase inicial de adição de 4-NF (Fase II) resultou no maior índice de 
dominância, todavia, observou-se redução desse índice $(0,1014)$ após aumento da concentração de 4-NF $\left(270,1 \pm 24,7 \mu \mathrm{g} \mathrm{L}^{-1}\right)$ na Fase II. A variação dos índices de diversidade e dominância pode ser observada na Figura 5.40.

Figura 5.40 - Variação dos Índices de diversidade e dominância para o Domínio Bacteria em todas as fases de operação do RALF e inóculo.

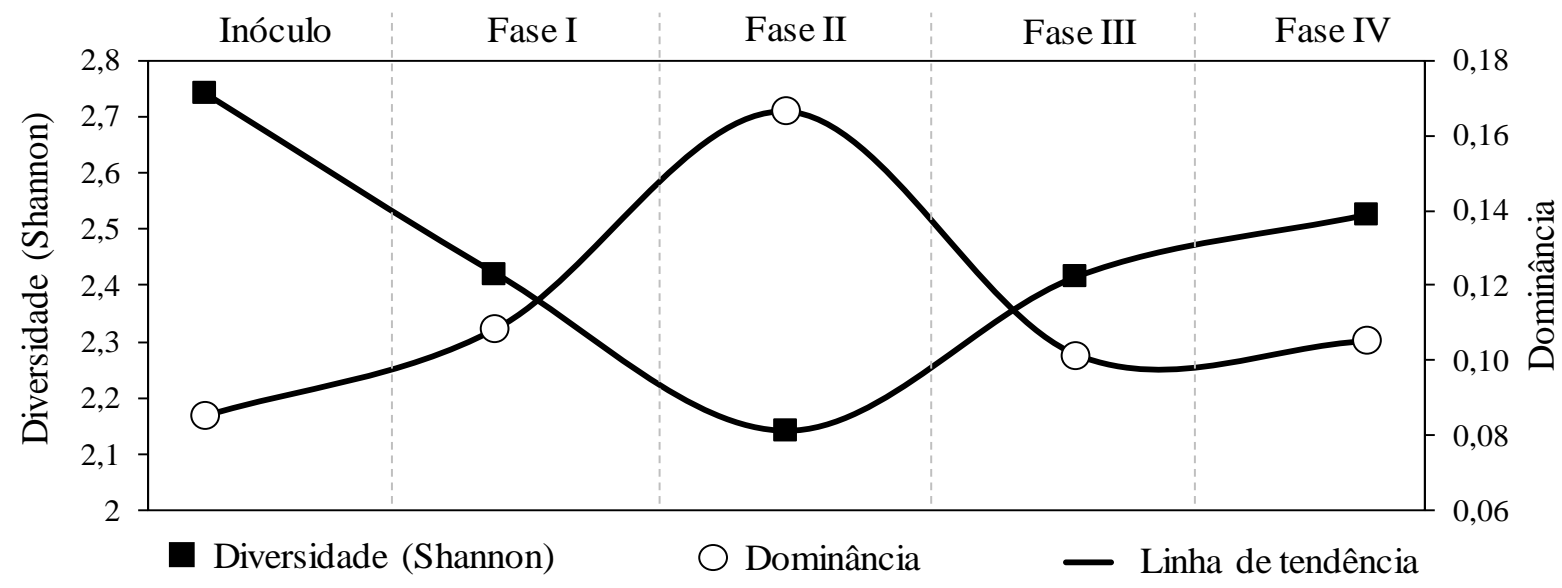

Fonte: $\mathrm{O}$ autor.

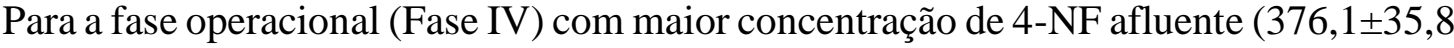
$\left.\mu \mathrm{g} \mathrm{L}^{-1}\right)$, foi verificado aumento no índice de riqueza (18) e diversidade $(2,53)$. Nesta fase operacional, além da maior concentração de 4-NF $\left(376,1 \pm 35,8 \mu \mathrm{g} \mathrm{L}^{-1}\right)$ também foi reduzida a concentração de co-substrato (etanol) na composição do meio de cultura (Tabelas 4.2 e 4.3), o que pode ter contribuído para o aumento dos índices de diversidade. A adição de co-substrato facilmente biodegradável a composição nutricional pode contribuir para o desenvolvimento de comunidade degradadora do composto de interesse (OKADA et al., 2014) e, uma vez adaptada, esta comunidade microbiana pode degradar o composto tóxico mesmo na ausência do cosubstrato (SANZ et al., 2003; DUARTE et al., 2010; MACEDO et al., 2015).

A degradação dos compostos aromáticos varia muito entre as diferentes espécies de organismos. Geralmente, o processo é regulado por vias periféricas e centrais e estas são controladas pela presença ou ausência de substratos específicos ou seus compostos intermediários (FUCHS; BOLL; HEIDER, 2011). Portanto, em meios reacionais com presença de substratos complexos é necessária maior diversidade de organismos e o sintrofismo destes para subsidiar a degradação destes compostos, como foi verificado no presente trabalho. $\mathrm{O}$ aumento da concentração de 4-NF no meio provocou aumento da diversidade e consequente aumento da eficiência de degradação deste composto, indicando que a comunidade microbiana 
estabelecida no reator desenvolveu ferramental para utilizar 4-NF como substrato em seus processos metabólicos.

\subsubsection{Domínio Archaea}

Por meio do perfil das bandas do DGGE para o domínio Archaea, foram verificadas alterações nas comunidades microbianas estabelecidas no leito de areia. A menor similaridade (51\%) ocorreu entre o inóculo e as demais fases operacionais do reator, mesmo comportamento observado para o domínio Bactéria (Figura 5.38). A menor similaridade pode ter ocorrido pela mudança da configuração reacional e composição nutricional do substrato, por conseguinte, alteração do perfil de populações de arqueias. (DEL NERY et al., 2016) .

A menor concentração de 4-NF $\left(127,4 \pm 29,2 \mu \mathrm{g} \mathrm{L}^{-1}\right)$ aplicada ao RALF ocasionou pequenas alterações na comunidade microbiana do domínio Archaea, expressa pela similaridade de $87 \%$ entre a fase sem adição de 4-NF (Fase I) e a fase inicial de adição de 4NF (Fases II). Os percentuais de similaridade para o domínio Archaea em cada fase de operação do RALF podem ser verificados no dendograma da Figura 5.41.

Figura 5.41 - Análise de cluster (Correlação de Pearson, UPGMA) do perfil das bandas do DGGE dos fragmentos do RNAr 16S para o Domínio Archaea de amostras do Inóculo, Fase I, II, III e IV do RALF.

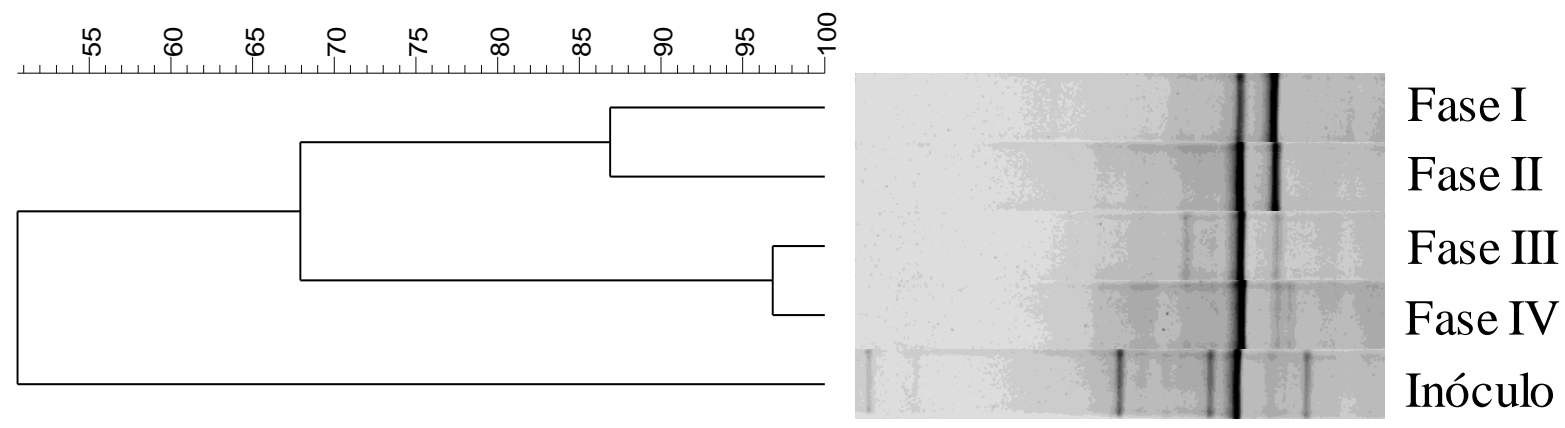

Fonte: $\mathrm{O}$ autor.

Por meio do perfil de bandas do DGGE para o domínio Archaea observou-se maior similaridade (97\%) entre as populações das Fases III e IV, o que pode estar relacionado as maiores concentrações afluente de 4-NF nessas fases $\left(270,1 \pm 24,7 \mu \mathrm{g} \mathrm{L}^{-1}\right.$ para Fase III e $376,1 \pm 35,8 \mu \mathrm{g} \mathrm{L}^{-1}$ para Fase IV). Portanto, o aumento da concentração de 4-NF provocou mudanças na composição da comunidade microbiana do RALF para o domínio Archaea, 
indicando que ocorreu seleção de microrganismos do domínio estabelecidos no biofilme, mesmo comportamento verificado anteriormente para o domínio Bacteria.

Em relação aos índices de diversidade, a adição de 4-NF ao reator causou alterações na composição da comunidade microbiana para o domínio Archaea. Os maiores valores de diversidade $(1,98)$, riqueza $(12)$ e equitabilidade $(0,7949)$ ocorreram na amostra de inóculo, o que resultou no menor índice de dominância $(0,1887)$. Este comportamento também foi verificado para o domínio Bacteria e pode estar relacionado a configuração reacional e composição nutricional do meio, uma vez que o inóculo (proveniente de reator UASB) estava adaptado a água residuária de avicultura, com ampla heterogeneidade de compostos orgânicos de fácil degradação; ou seja, meio complexo nutricionalmente adequado para suprir diversidade maior de populações. Os valores referentes aos índices de diversidade para o Domínio Archaea em todas as fases de operação do RALF e no inóculo podem ser verificados na Tabela 5.22.

Tabela 5.22 - Índices de diversidade para o Domínio Archaea em todas as fases de operação do RALF e inóculo.

\begin{tabular}{lccccc}
\multicolumn{1}{c}{ Índice } & Inóculo & Fase I & Fase II & Fase III & Fase IV \\
\hline Dominância & 0,1887 & 0,4785 & 0,3967 & 0,4616 & 0,4394 \\
Diversidade & 1,98 & 0,81 & 1,05 & 1,03 & 1,16 \\
Equitabilidade & 0,7949 & 0,7378 & 0,7601 & 0,7427 & 0,7184 \\
Riqueza & 12 & 3 & 4 & 4 & 5 \\
\hline
\end{tabular}

Os menores valores de riqueza e diversidade $(0,81)$ e riqueza (3) ocorreram na fase controle (Fase I), sem adição de 4-NF. Isto pode estar relacionado a simplicidade do meio nutricional usado (Tabela 4.2Tabela 4.3) em comparação aquele a qual a biomassa estava submetida (efluente de abatedouro de aves) anteriormente a sua inoculação no RALF. Este mesmo comportamento também foi verificado para o domínio Bacteria.

Após adição de 4-NF no RALF (Fase II) foi verificado aumento da riqueza (de 3 para 4) e diversidade (de 0,81 para 1,03), em comparação a fase sem adição de 4-NF (Fase I), indicando que a presença de 4-NF no meio reacional não apresentou efeito negativo aos representantes do domínio Archaea estabelecidas no reator. $\mathrm{O}$ aumento da diversidade e riqueza pode ter sido consequência do aumento de riqueza e diversidade anteriormente verificadas para 
o domínio Bacteria, uma vez que a comunidade de arqueias pode consumir diversos subprodutos gerados por bactérias.

Dentre todas as fases operacionais do RALF (Fase I, II, III e IV) os maiores valores para os índices de riqueza $(5)$ e diversidade $(1,16)$ foram verificados para a Fase IV, a qual também

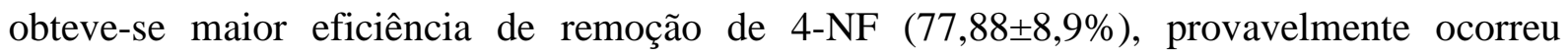
adaptação da biomassa com concentrações crescentes do composto de interesse (4-NF) aliada a adição de co-substrato ao meio nutricional (etanol). Essa possibilidade é alternativa eficaz para obter um consórcio potencialmente degradador de 4-Nonilfenol. A variação dos índices de diversidade e riqueza para o Domínio Archaea pode ser observada na Figura 5.42.

Figura 5.42 - Variação dos Índices de diversidade e riqueza para o Domínio Archaea em todas as fases de operação do RALF e inóculo.

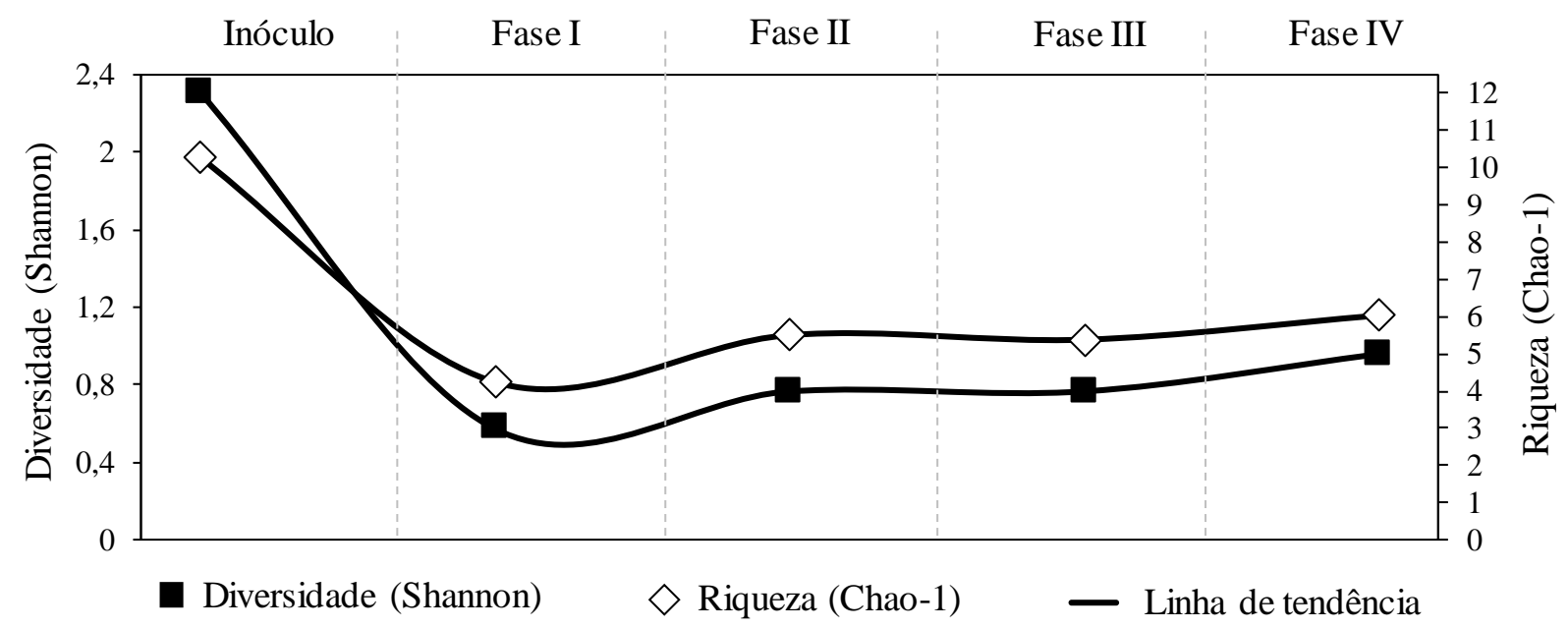

Fonte: $\mathrm{O}$ autor.

Motteran et al. (2014) avaliaram a degradação de surfactante não iônico (LAE) em reator anaeróbio de leito fluidificado em escala de bancada $(1.256 \mathrm{~mL})$, operado em TDH 18 horas e mantido a temperatura de $30{ }^{\circ} \mathrm{C}$; após longo período operacional (380 dias) com adaptação da biomassa a condição nutricional. Os autores suprimiram adição de co-substrato (sacarose) a alimentação do reator e verificaram aumento da diversidade $(2,63)$ e consequente aumento da eficiência de remoção de surfactante (99\%) e DQO $(83 \pm 11 \%)$, similar ao comportamento verificado no presente trabalho, com adição de 4-NF.

Observou-se para a maior concentração de 4-NF aplicada na Fase IV $\left(376,1 \pm 35,8 \mu \mathrm{g} \mathrm{L} \mathrm{L}^{-}\right.$ $\left.{ }^{1}\right)$ menor equitabilidade em relação a fase com menor concentração de 4-NF (Fase II: $\left.127,4 \pm 29,2 \mu \mathrm{g} \mathrm{L}^{-1}\right)$. Provavelmente, o aumento de 4-NF provocou maior dominância $(0,4785)$ de organismos para o domínio Archaea. 
De maneira geral, a adição de 4-NF (Fase II) a alimentação do RALF provocou redução imediata da diversidade $(0,81)$ e aumento da dominância $(0,4785)$ para organismos do domínio Archaea. Todavia, o aumento das concentrações de 4-NF afluente (Fase III e IV) aliado ao longo período de operação propiciou adaptação da biomassa do leito de areia.

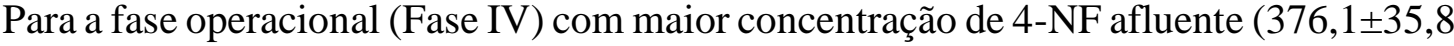
$\left.\mu \mathrm{g} \mathrm{L}^{-1}\right)$, verificou-se a maior diversidade $(1,16)$. Nesta fase operacional, além da maior concentração de 4-NF também foi reduzida a adição de o co-substrato (etanol) na composição do meio de cultura (Tabela 4.2 e Tabela 4.3), o que pode ter contribuído para o aumento do índice de diversidade (Figura 5.43).

Figura 5.43 - Variação dos Índices de diversidade e dominância para o Domínio Archaea em todas as fases de operação do RALF e inóculo.

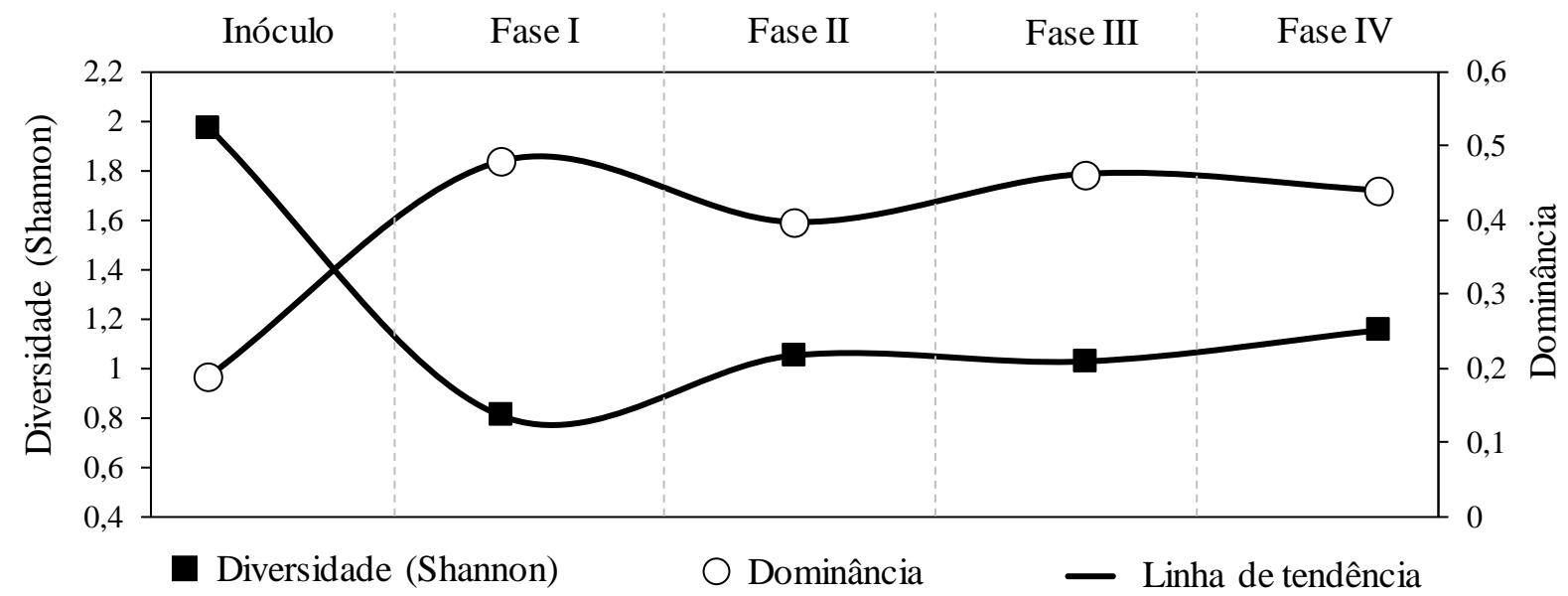

Fonte: $\mathrm{O}$ autor.

Assim sendo, por meio da análise do coeficiente de Pearson do perfil de bandas do DGGE, constatou-se que a presença de 4-NF provocou mudanças na composição da comunidade microbiana do RALF em escala aumentada, tanto para o domínio Archaea quanto Bacteria, com imediata redução da riqueza e diversidade e aumento de dominância após a primeira fase de adição de 4-NF, seguido de aumento dos índices com aumento das concentrações de 4-NF afluente, sugerindo seleção da comunidade microbiana de arqueias e bactérias. 


\subsubsection{Caracterização microbiana Illumina MiSeq}

Ao todo foram identificados 146 gêneros, divididos em 280 Unidades a Taxonômicas Operacionais $^{24}$ (UTOs). O maior número de gêneros (137) foi identificado na Fase I, referente a fase inicial de operação do RALF, sem 4-NF. O menor número de gêneros (128) foi identificado na biomassa de aspecto granular formada sobre o leito de areia na Fase III, com

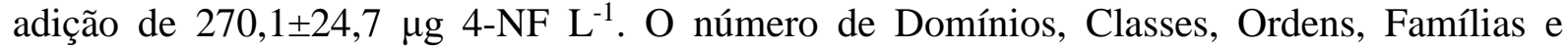
Gêneros para todas as amostras podem ser verificados na Tabela 5.23.

Tabela 5.23 - Índices de diversidade para o Domínio Archaea em todas as fases de operação do RALF.

\begin{tabular}{cccccc}
\hline Amostra & Domínio & Classe & Ordem & Família & Gêneros \\
\hline Inóculo & 2 & 30 & 56 & 86 & 131 \\
Fase I & 2 & 30 & 55 & 90 & 137 \\
Fase III & 2 & 31 & 55 & 88 & 131 \\
Grânulo & 2 & 31 & 56 & 88 & 128 \\
\hline
\end{tabular}

Verificou-se alta cobertura amostral por meio da análise das curvas de rarefação e observação do platô, ou seja, o número de sequências obtido foi satisfatório para acessar toda a diversidade das amostras. Acima de 3.000 sequências notou-se tendência à saturação. As curvas de Rarefação para as amostras do Inóculo, fases de operação do RALF e grânulos podem ser verificadas na Figura 5.44.

\footnotetext{
24 A UTO é utilizada para classificação de organismos com base no máximo de características comuns; o agrupamento em UTO é comumente usado na análise de sequenciamento de próxima geração do gene 16S rRNA (EDGAR, 2018).
} 
Figura 5.44 - Curva de rarefação (similaridade de 95\%) das sequências de amostra do Inóculo (A) Fase I (B), Fase III (B) e Grânulos (C) do RALF.
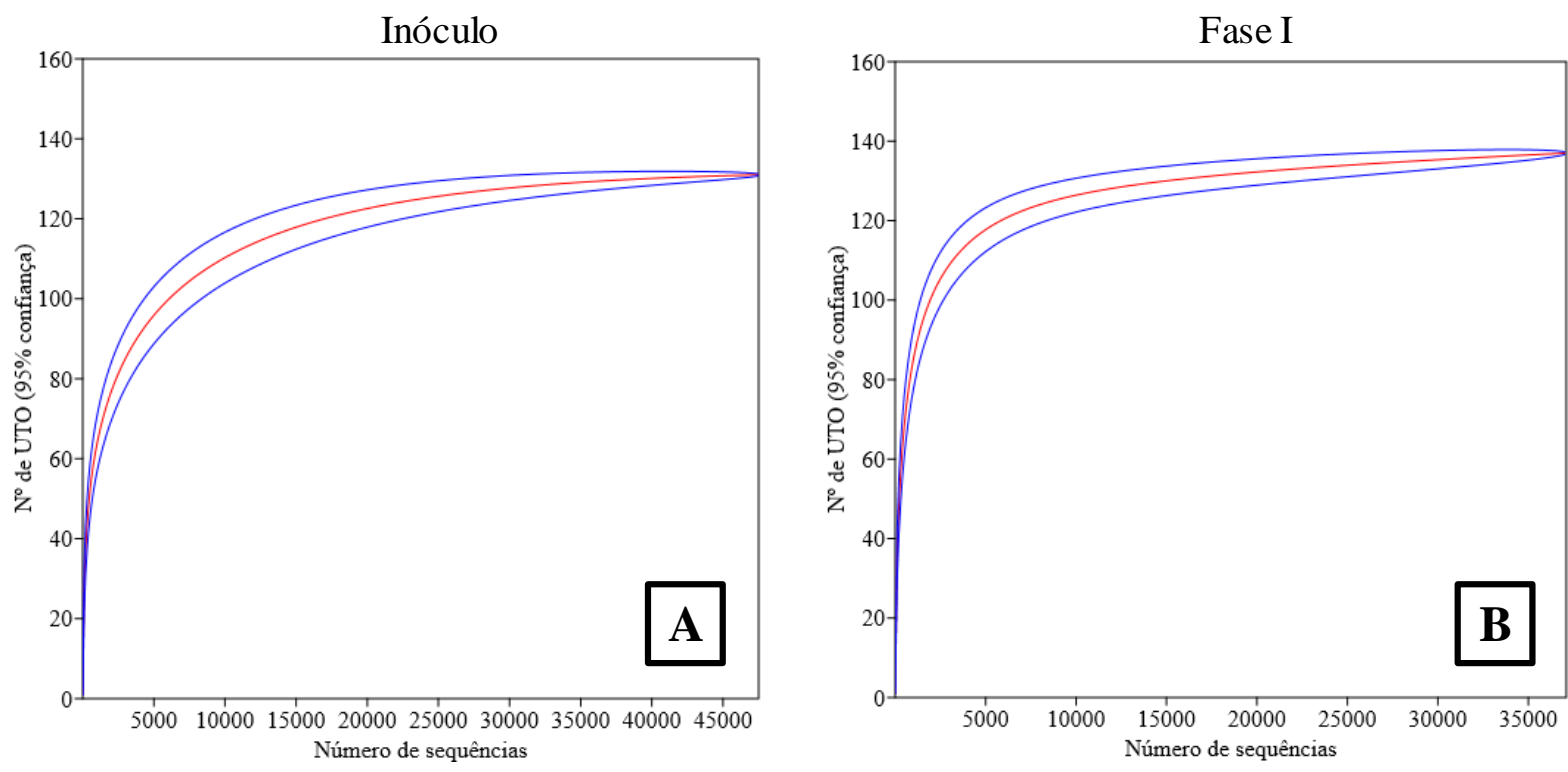

Fase III

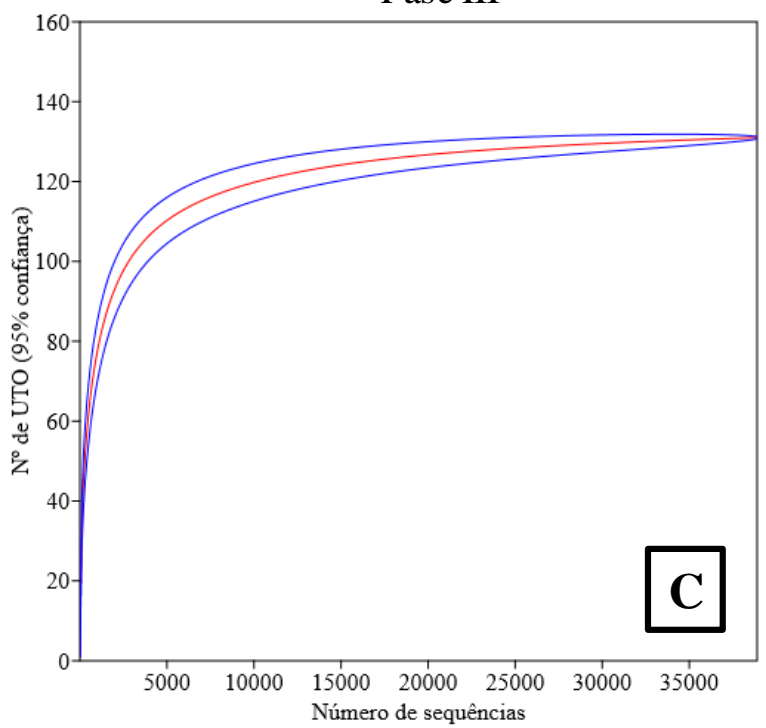

Grânulo

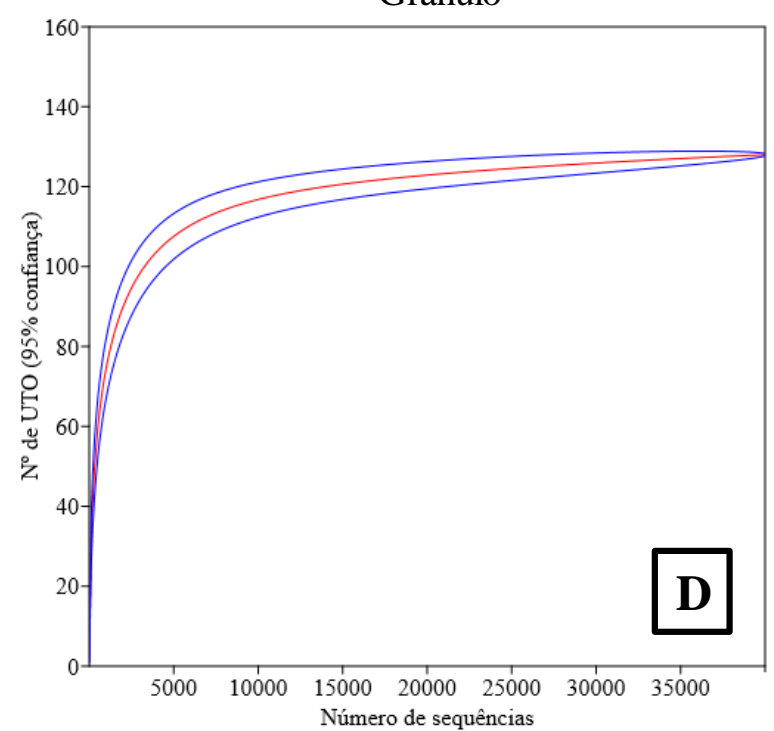

Fonte: $\mathrm{O}$ autor.

Em relação aos domínios verificou-se, para o inóculo, maior percentual de organismos do domínio Archaea (53,93\%), enquanto o maior percentual de representantes do domínio Bacteria foi observado na Fase III $(97,1 \%)$, referente a adição de $270,1 \pm 24,7 \mu \mathrm{g} 4-\mathrm{NF} \mathrm{L}^{-1}$. O maior percentual de representantes do domínio Archaea verificado no Inóculo pode estar relacionado a configuração reacional; proveniente de reator UASB usado para o tratamento de água residuária de abatedouro de aves, portanto, com maior aporte orgânico e alta produção de metano (DEL NERY et al., 2016, 2018) 
A distribuição percentual de representantes dos domínios para cada amostra pode ser verificada na Figura 5.45.

Figura 5.45 - Percentual de gêneros do domínio Archaea e Bacteria identificados em amostra do Ínoculo e fases de operação do RALF.

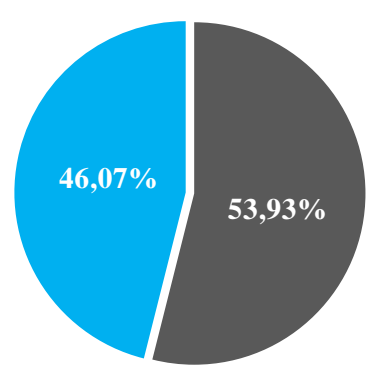

Inóculo

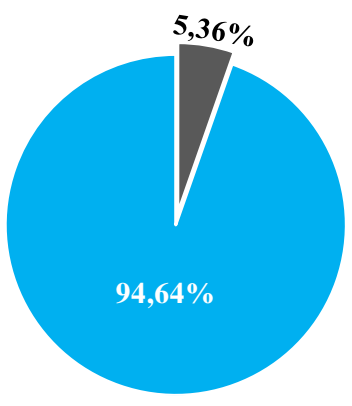

Fase I

Domínio Bacteria

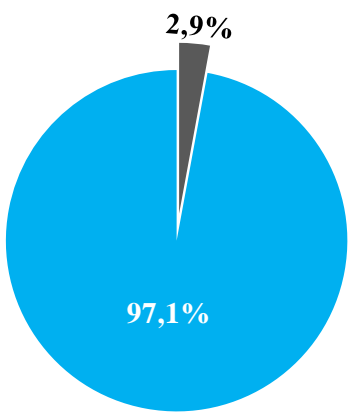

Fase III

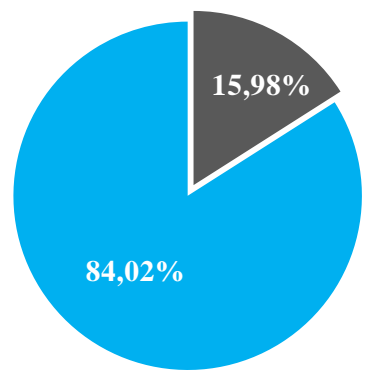

Grânulos

Domínio Archaea

Fonte: $\mathrm{O}$ autor.

Ocorreu redução percentual de representantes do domínio Archaea na biomassa do RALF após adição de 4-NF (Fase III), em comparação com a amostra sem adição de 4-NF (Fase I). A redução de gêneros de arqueias no leito de areia após adição de 4-NF (Fase III) pode estar relacionada a estratificação do leito (areia e granular) e não a toxicidade do 4-NF, uma vez que no leito com aspecto granular verificou-se $15,98 \%$ de gêneros pertencentes a Archaea. Organismos que compõem o domínio Archaea podem desempenhar importante papel em processos de biorremediação, uma vez que podem sobreviver em condições extremas (temperatura, salinidade, toxicidade) e consumir subprodutos gerados por bactérias, promovendo a completa degradação de contaminantes (KRZMARZICK et al., 2018).

\subsubsection{Filos}

Identificou-se representantes de quinze filos em diferentes abundâncias relativas, a saber: Acidobacteria, Actinobacteria, Bacteroidetes, Candidatus Cloacimonetes, Chlorobi, Chloroflexi, Cyanobacteria, Elusimicrobia, Euryarchaeota, Firmicutes, Ignavibacteriae, Proteobacteria, Spirochaetes, Synergistetes e Thermotogae. A comparação entre a abundância relativa dos filos identificados no Inóculo, Leito de Areia sem adição de 4-Nonilfenol (Fase I), Leito de Areia após adição de 4-Nonilfenol (Fase III) e Leito com aspecto Granular com adição de 4-Nonilfenol (Grânulos) pode ser verificada na representação circular da Figura 5.46. 
Figura 5.46 - Abundância relativas dos filos identificados em amostra do Inóculo e RALF (Fase I, Fase III e Grânulos).

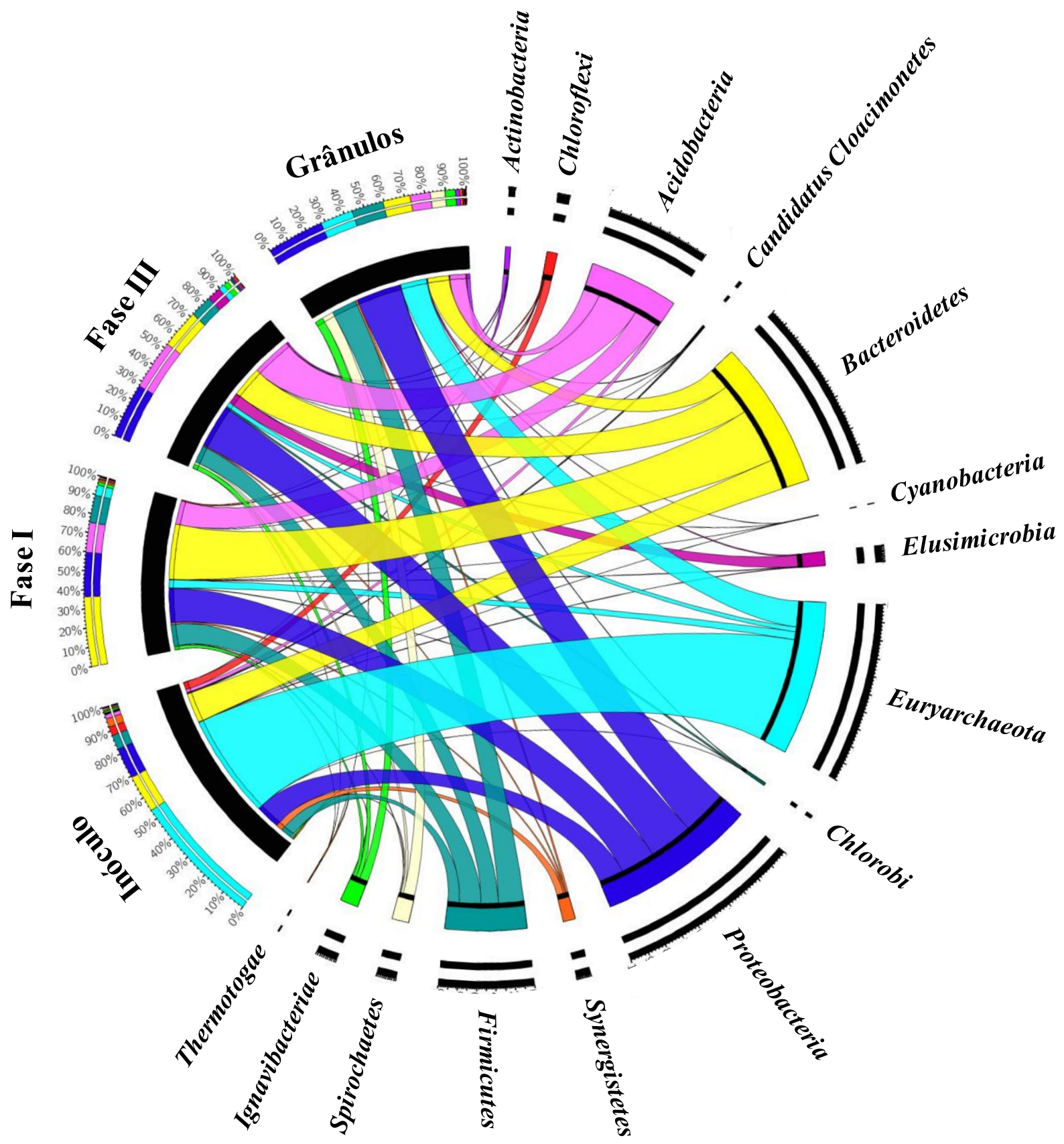

Fonte: $\mathrm{O}$ autor.

Para o inóculo observou-se maior abundância dos filos: Euryarchaeota $(53,93 \%)$, Bacteroidetes (15,53\%), Proteobacteria (12,69\%), Firmicutes (5,95\%), Chloroflexi (3,64\%). A maior abundância $(53,93 \%)$ para o domínio Archaea (Euryarchaeota) pode estar relacionada a 
configuração reacional estritamente anaeróbia (UASB) e condição nutricional (efluente de abatedouro de aves) a qual o inóculo foi proveniente (DEL NERY et al., 2016).

Em relação a Fase I de operação do RALF foram verificados os seguintes filos com maior abundância: Bacteroidetes (36,60\%), Proteobacteria (22,99\%), Acidobacteria (15,72\%), Firmicutes (14,35\%) e Euryarchaeota (5,36\%). Provavelmente, representantes desses filos se adaptaram a configuração reacional (RALF) e simplicidade das condições nutricionais impostas (Tabela 4.2 e Tabela 4.3).

Verificou-se aumento na abundância relativa na Fase I para os filos Bacteroidetes (de 15,53 para 36,60\%), Proteobacteria (de 12,69 para 22,99\%), Acidobacteria (de 1,65 para $15,72 \%$ ), Firmicutes (de 5,95 para 14,35\%), Ignavibacteriae (de 0,67 para 1,93\%), Spirochaetes (de 0,5 para 0,55\%) e Elusimicrobia (de 0,23 para 0,37\%), em comparação a amostra de Inóculo. A configuração reacional usada neste trabalho (RALF) possui características distintas da configuração reacional a qual o inóculo foi proveniente (UASB), como alta turbulência da massa líquida ocasionada pela recirculação do efluente, baixa resistência a transferência de massa e crescimento microbiano na forma de biofilme aderido ao material suporte.

$\mathrm{Na}$ Fase III do reator com 270,1 $\pm 24,7 \mu \mathrm{g}$ L-1 de 4-NF verificou-se representantes pertencentes aos filos com maior abundância para Proteobacteria (27,40\%), Acidobacteria (24,98\%), Bacteroidetes (19,39\%), Firmicutes (11,00\%) e Elusimicrobia (6,98\%). Houve aumento na abundância relativa após a adição de 4-NF (Fase III) para os filos Proteobacteria (de 22,99 para 27,40\%), Acidobacteria (de 15,72 para 24,98\%), Ignavibacteriae (de 1,93\% para 2,64\%), Spirochaetes (de 0,55 para 1,45\%), Actinobacteria (de 0,09 para 0,91\%) e Chlorobi (de 0,29 para $1,10 \%$ ), em comparação a fase controle (Fase I)

$\mathrm{Na}$ biomassa do leito com aspecto granular (Grânulos) da Fase III, após adição de $270,1 \pm 24,7 \mu \mathrm{g}$ L-1 de 4-Nonilfenol, foi verificada maior abundância relativa dos filos Proteobacteria (27,93\%), Euryarchaeota (15,98\%), Firmicutes (15,52\%), Bacteroidetes $(13,25 \%)$ e Acidobacteria (9,99\%). O aumento da abundância relativa do filo Euryarchaeota $(15,98 \%)$ no leito granular (Grânulos) em comparação a abundância deste no leito de areia da Fase III (2,90\%), pode ser indicativo da participação de organismos pertencentes ao filo Euryarchaeota no processo de granulação do leito. 


\subsubsection{Gêneros}

Dentre os 146 gêneros identificados, 80,1\% deles estiveram presentes em todas as amostras (Inóculo, Fase I, Fase III e Grânulos). Cerca de 1,4\% dos gêneros identificados foram exclusivos da amostra do leito de areia anterior adição de 4-NF (Fase I). Para a amostra do leito de areia após a adição de 4-NF (Fase III) verificou-se 1,4\% de gêneros exclusivos desta condição. A distribuição do percentual de similaridade dos gêneros identificados entre amostras (Inóculo, Fase I, Fase III e Grânulos) pode ser verificada pelo diagrama de Venn da Figura 5.47.

Figura 5.47 - Diagrama de Venn para presença de gêneros identificados em amostras de Inóculo, Fase I, Fase III e Grânulos.

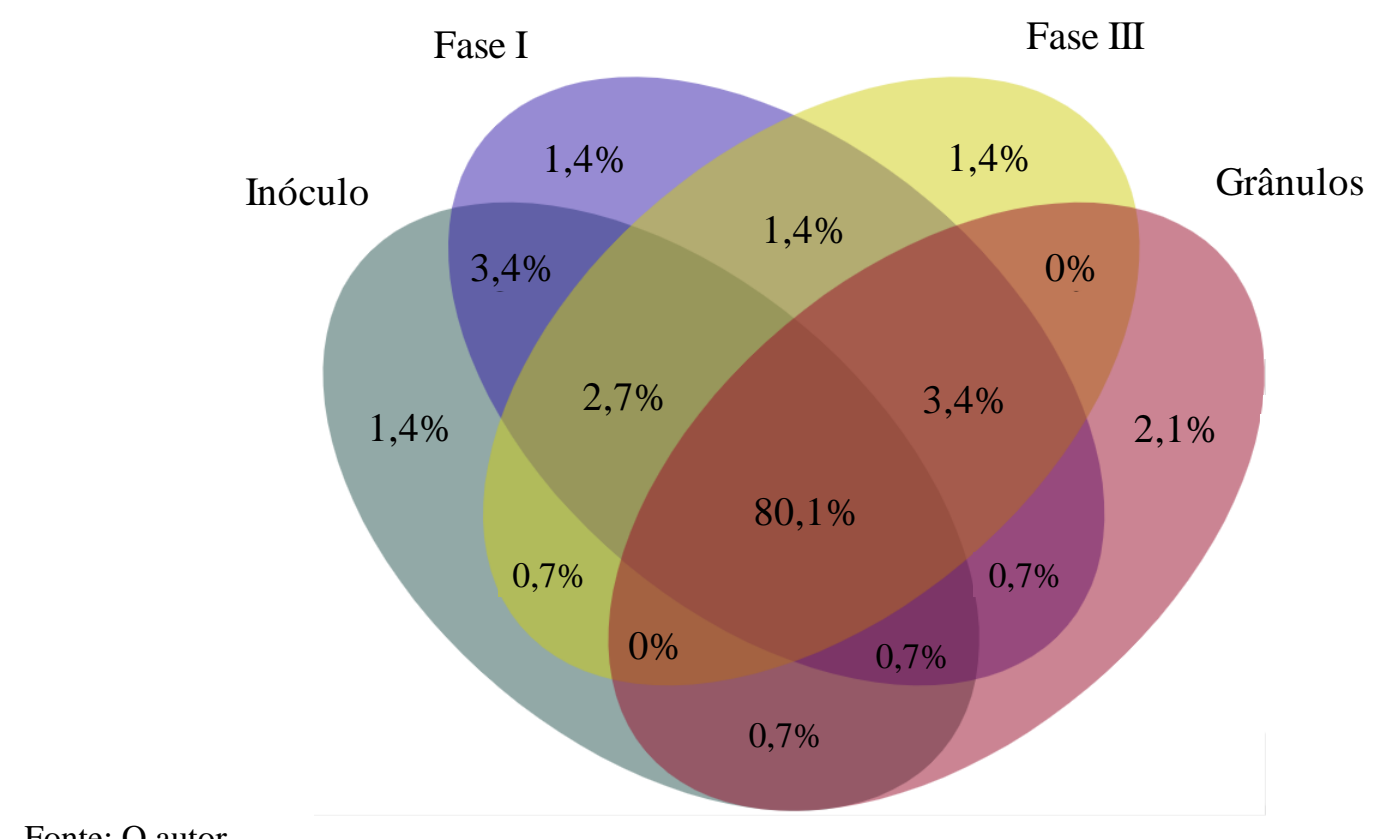

Fonte: $\mathrm{O}$ autor.

Para a construção da Figura 5.47 foram analisadas apenas presença ou ausência dos gêneros, sem considerar a abundância. Na Figura 5.48 foram selecionados gêneros com abundância relativa superior a $1 \%$ e distribuídos de acordo com sua presença ou ausência em cada amostra.

Para os gêneros identificados com abundância relativa superior a $1 \%$, apenas 5,1 estiveram presentes em todas as amostras. Cerca de 6,3\% dos gêneros (com abundância relativa 
superior a 1\%) foram exclusivos do leito de areia das Fase I e III e 7,6\% foram específicos do leito de areia após a adição de 4-NF (Fase III). Pelo diagrama de Venn da Figura 5.48 pode ser verificada a distribuição do percentual de similaridade dos gêneros identificados com abundância relativa superior a $1 \%$.

Figura 5.48 - Diagrama de Venn para presença de gêneros identificados com abundância relativa superior a 1\%, em amostras de Inóculo, Fase I, Fase III e Grânulos.

Fase I

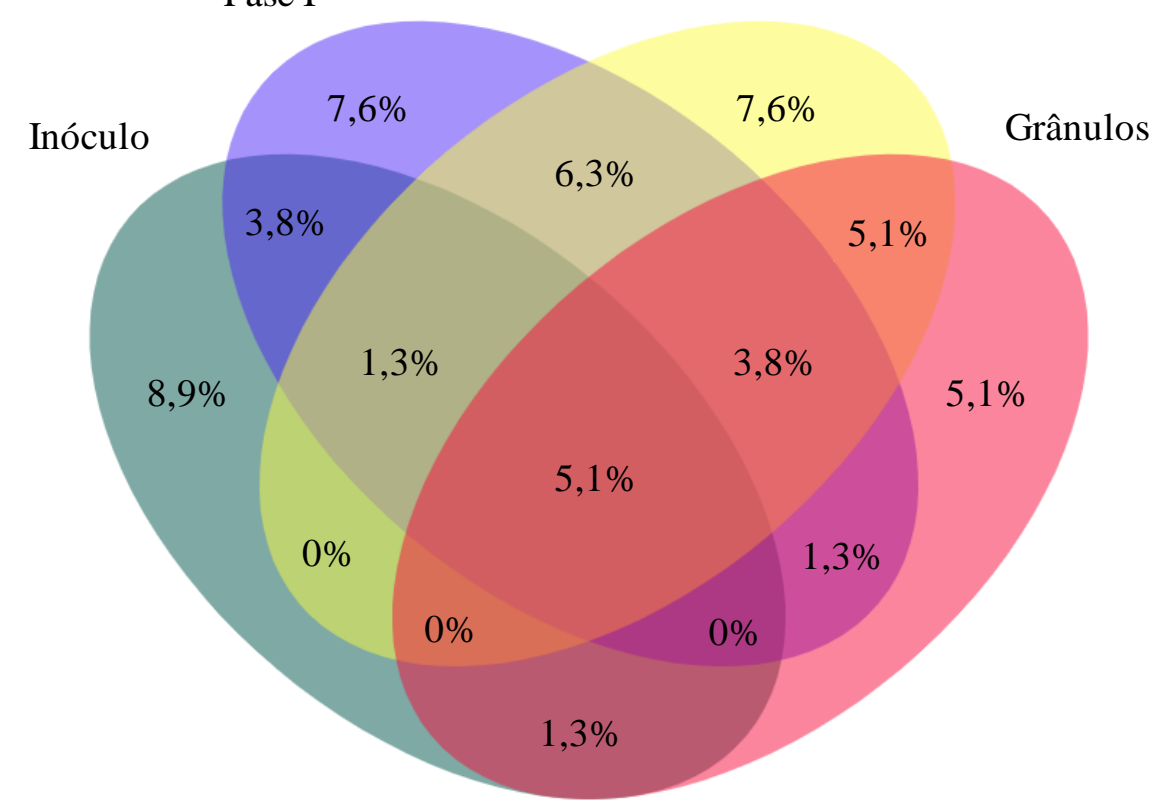

Fonte: $\mathrm{O}$ autor.

Os dez gêneros mais abundantes identificados no inóculo foram Methanosaeta (43,04\%), Methanoregula (5,36\%) e Methanosphaerula (3,22\%) para o Domínio Archaea. Em relação ao Domínio Bacteria foram identificados Mariniphaga (5,54\%), Geobacter (3,86\%), Paraclostridium (3,55\%), Anaerolinea (3,53\%), Syntrophus (3,02\%), Owenweeksia (2,52\%) e Cloacibacillus (2,37\%). Os demais gêneros identificados na amostra de inóculo (com exceção dos supracitados) compuseram $24,01 \%$ da abundância relativa.

Para a amostra de biofilme da areia da Fase I, os dez gêneros identificados mais abundantes foram Prolixibacter (20,38\%), Geothrix (14,12\%), Klebsiella (5,35\%), Lactobacillus (3,75\%), Geobacter (3,44\%), Syntrophothermus (3,03\%), Paludibacter (2,90\%), Paraclostridium (2,78\%) e Alistipes $(2,84 \%)$ para o Domínio Bacteria e somente Methanobacterium (3,06\%) para o Domínio Archaea. A soma dos demais gêneros identificados representou $38,96 \%$. 
A comparação entre os dez gêneros com maior abundância relativa identificados no Inóculo, Leito de Areia sem adição de 4-Nonilfenol (Fase I), Leito de Areia após adição de 4Nonilfenol (Fase III) e Leito com aspecto Granular com adição de 4-Nonilfenol (Grânulos) pode ser verificada na representação circular ilustrada na Figura 5.49.

Figura 5.49 - Representação circular dos dez gêneros com maior abundância relativas para Inóculo, Leito de Areia sem adição de 4-Nonilfenol (Fase I), Leito de Areia após adição de 4NF (Fase III) e Leito com aspecto Granular com adição de 4-Nonilfenol (Grânulos).

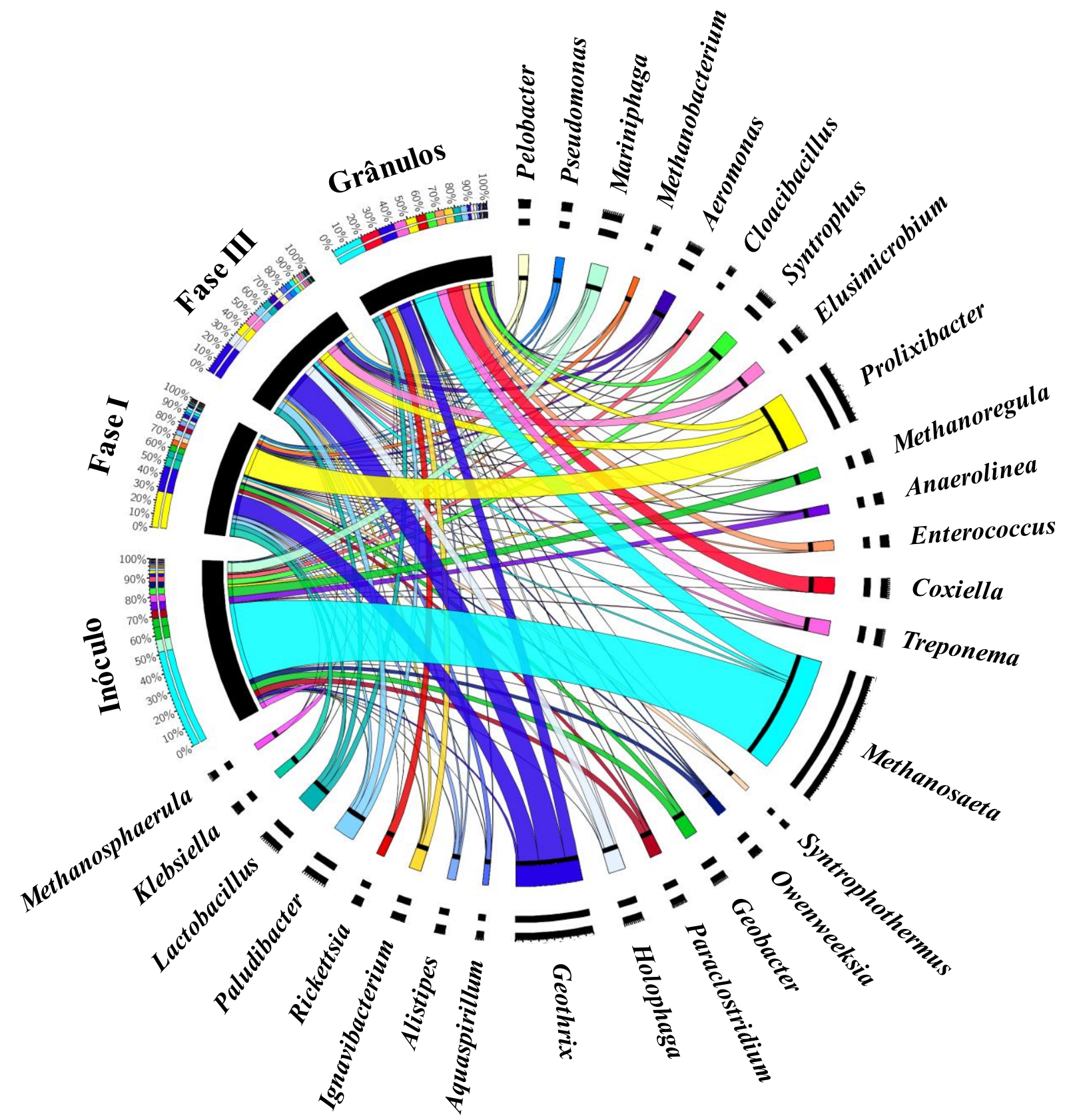

Fonte: $\mathrm{O}$ autor. 
A representação circular da Figura 5.49 apresenta total de 29 gêneros, sendo que cada gênero apresentado foi o mais abundante em pelo menos uma das amostras.

Para a amostra de biofilme da areia da Fase III (após adição de 270,1 $24,7 \mu \mathrm{g} \mathrm{L}^{-1}$ ), os dez gêneros mais abundantes identificados foram Geothrix (17,82\%), Holophaga (7,11\%), Prolixibacter (7,03\%), Elusimicrobium (6,98\%), Paludibacter (5,60\%), Lactobacillus (4,27\%), Aeromonas (4,20\%), Pelobacter (3,92\%), Aquaspirillum (2,98\%) e Pseudomonas (2,86\%), todos pertencentes ao domínio Bacteria. A soma dos demais gêneros representou 37,23\%.

Para a amostra da biomassa com aspecto granular (Grânulos) (após adição de $\left.270,1 \pm 24,7 \mu \mathrm{g} \mathrm{L}^{-1}\right)$, os dez gêneros mais abundantes identificados foram Coxiella (9,96\%), Geothrix (8,34\%), Treponema (6,60\%), Prolixibacter (5,44\%), Rickettsia (5,00\%), Syntrophus (4,92\%), Enterococcus (4,78\%), Ignavibacterium (4,71\%) e Lactobacillus (3,92\%) para o Domínio Bacteria e somente Methanosaeta $(15,65 \%)$ para o domínio Archaea. A soma dos demais gêneros representou $31,40 \%$.

Para avaliar os gêneros que melhor se adaptaram a configuração reacional (RALF) e condições nutricionais (Tabela 4.2 e Tabela 4.3) usadas neste trabalho, foram selecionados os 17 gêneros mais abundantes na amostra do Inóculo (em tons de amarelo) e na Fase I (em tons de azul). Por meio do perfil de cores da Figura 5. 50 pode-se verificar que houve grande diferenciação na composição da comunidade microbiana devido a alteração da configuração reacional e composição nutricional.

Verificou-se aumento na abundância relativa superior a 90\% para Prolixibacter, Klebsiella, Lactobacillus, Syntrophothermus, Enterobacter, Chryseobacterium e Prevotella na Fase I em comparação ao Inóculo.

Especificamente, para Geothrix e Clostridium observou-se aumento superior a $80 \% \mathrm{em}$ abundância relativa na Fase I, em comparação a abundância verificada na amostra de Inóculo.

Em relação a Methanobacterium, Alistipes, Aeromonas e Holophaga verificou-se aumento superior a $70 \%$ em sua abundância relativa na Fase I, em comparação ao observado para o Inóculo. A comparação entre os gêneros mais abundantes para a amostra do Inóculo e Fase I pode ser verificada na representação circular da Figura 5. 50. 
Figura 5. 50 - Abundância relativa dos gêneros identificados no lodo de Inóculo (Inóculo) e no Leito de Areia sem adição de 4-Nonilfenol (Fase I).

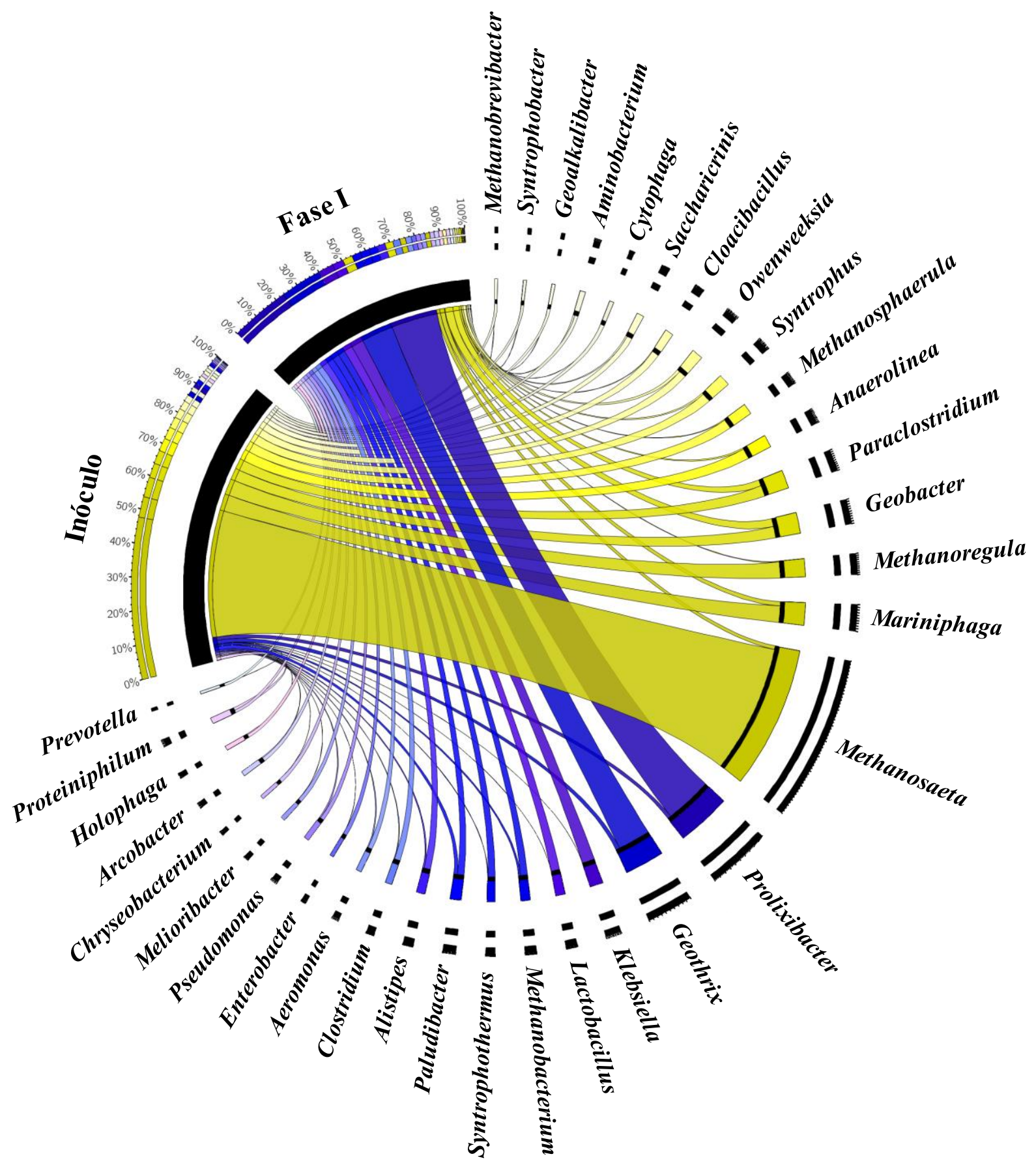

Fonte: $\mathrm{O}$ autor.

Foi constatada redução da abundância relativa de representantes do domínio Archaea na Fase I em comparação ao Inóculo, para organismos similares Methanosaeta (de 43,04\% para 1,56\%), Methanoregula (de 5,36\% para 0,29\%), Methanosphaerula (de 3,22\% para 0,29\%), Methanobrevibacter (de 0,86\% para 0,12\%), Methanomassiliicoccus (de 0,57\% para 0,04\%), 
Methanospirillum (de 0,22\% para 0,003\%) e Candidatus Methanomethylophilus (de 0,008\% para $0,003 \%$ ). O único representante do domínio Archaea para o qual verificou-se aumento na abundância na Fase I em comparação ao Inóculo foi para o gênero Methanobacterium, o qual aumentou de 0,65\% (Inóculo) para 3,06\% (Fase I). Organismos representantes de Methanobacterium são metanogênicos hidrogenotróficos e são comumente encontrados em sintrofismo com arqueias metanogênicas acetoclásticas similares a Methanosaeta (BOONE; WHITMAN; ROUVIERE, 1993), identificadas no presente estudo com abundância relativa de $1,56 \%$ para a fase controle (Fase I).

Em relação a amostra referente ao leito de areia (Fase III), a adição de 4-NF provocou redução da abundância relativa de organismos semelhantes a Prolixibacter Klebsiella, Geobacter, Methanobacterium, Syntrophothermus Alistipes, Paraclostridium, Clostridium, Mariniphaga, Enterobacter, Melioribacter, Chryseobacterium, Owenweeksia, Proteiniphilum, Prevotella, Wandonia e Stenotrophomonas, em comparação aos gêneros da fase sem adição de 4-NF (Fase I).

Na fase III (4-NF a 270,1 $\pm 24,7 \mu \mathrm{g} \mathrm{L}^{-1}$ ) verificou-se aumento da abundância relativa para organismos semelhantes a Geothrix, Holophaga, Elusimicrobium, Paludibacter, Lactobacillus, Aeromonas, Pelobacter, Aquaspirillum, Pseudomonas, Delftia, Acinetobacter, Arcobacter, Ignavibacterium, Treponema, Lysinibacillus e Enterococcus, em comparação a fase sem adição de 4-NF (Fase I).

A maior abundância relativa após adição de 4-NF ao RALF (Fase III), em relação a fase controle (Fase I), ocorreu para o gênero Geothrix (17,82\%), correspondendo a 25\% de aumento em comparação a fase sem adição de 4-Nonilfenol. Geothrix é gram-negativa, realiza fermentação e respiração anóxica. Cresce na presença de ácidos orgânicos e seus produtos finais da fermentação são ácidos acético e succínico. Geothrix está diretamente relacionado a degradação de hidrocarbonetos aromáticos (COATES et al., 1999), além de já ter sido identificado em reatores biológicos usados na degradação de surfactante aniônico LAS (OKADA, 2012; DELFORNO et al., 2015).

Para avaliar o efeito do 4-NF na comunidade microbiana estabelecida no leito de areia do RALF, foram selecionados os 17 gêneros mais abundantes na amostra da Fase I e Fase III $\left(270,1 \pm 24,7 \mu \mathrm{g} \mathrm{L}^{-1}\right.$ 4-NF). Para a composição da representação circular, os gêneros foram divididos em dois grupos: laranja (diminuição da abundância relativa após a adição de 4-NF) e azul (aumento da abundância relativa após a adição de 4-NF). A comparação entre os gêneros mais abundantes para a amostra da Fase I e Fase III pode ser verificada na representação circular da Figura 5.51. 
Figura 5.51 - Abundância relativa dos gêneros identificados no Leito de Areia sem adição de 4-Nonilfenol (Fase I) e após adição de 270,1 $\pm 24,7 \mu \mathrm{g} \mathrm{L}^{-1}$ 4-Nonilfenol (Fase III).

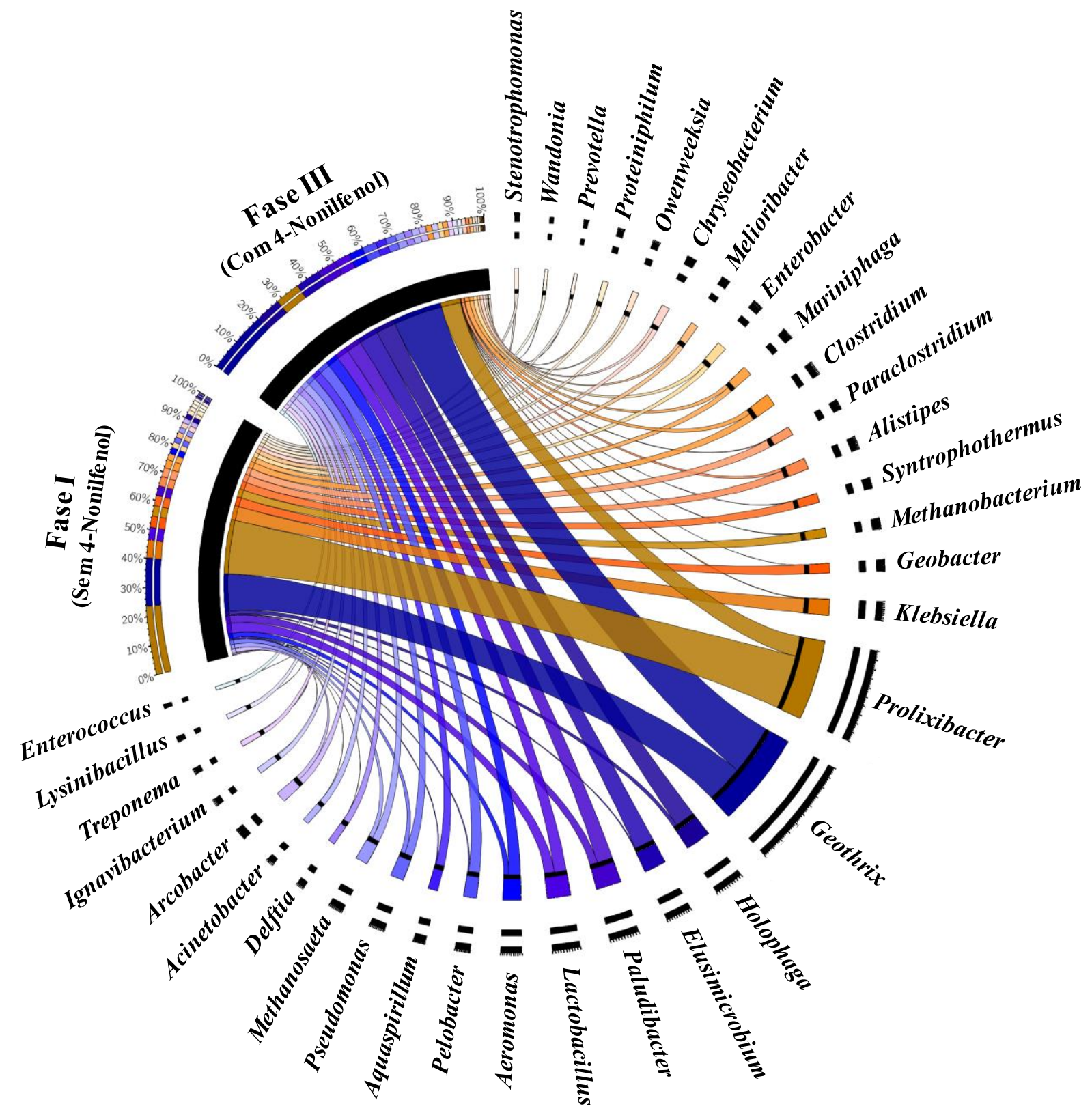

Fonte: $\mathrm{O}$ autor.

Holophaga foi o segundo gênero identificado em maior abundância $(7,06 \%)$ após a adição de 4-NF. Espécies desse gênero são gram-negativas, possuem metabolismo estritamente anaeróbio e obrigatoriamente fermentativo. Fermentam compostos aromáticos em ácido acético (LIESACK et al., 1994; KRIEG et al., 2010). Sua presença já foi associada a degradação de 
surfactante aniônico em reatores biológicos contínuos (OLIVEIRA et al., 2009, 2010; CAROSIA et al., 2014; OKADA et al., 2014; BRAGA et al., 2015; DELFORNO et al., 2015, 2017; MACEDO et al., 2015).

Bactérias semelhantes a Elusimicrobium foram também mais abundantes (6,93\%) após a adição de 4-NF. Tais bactérias possuem estrutura celular gram-negativa e metabolismo estritamente anaeróbio, mesmo na presença de espécies reativas ao oxigênio molecular. Utilizam vias fermentativas típicas para converter açúcares e amino ácidos em $\mathrm{H}_{2}, \mathrm{CO}_{2}$, etanol e ácido acético (HERLEMANN et al., 2009).

Em relação a Paludibacter verificou-se $51 \%$ de aumento em sua abundância relativa após adição de 4-NF. São gram-negativas estritamente anaeróbias. Espécies deste gênero são sacarolíticas e geram, como produto final da fermentação, ácido acético e propiônico (KRIEG et al., 2010).

Para Lactobacillus verificou-se aumento em sua abundância relativa de cerca de $17 \%$ após adição de 4-NF. Este gênero é encontrado nos mais diversos compartimentos ambientais e trato intestinal de espécies de animais e humanos. São organismos gram-negativos produtores de ácido lático que apresentam diversa enzimas glicolíticas (CLAESSON; VAN SINDEREN; O’TOOLE, 2008; BOEKHORST et al., 2015; BRANDT; BARRANGOU, 2018).

Verificou-se para Aeromonas aumento de $57 \%$ em sua abundância relativa após adição de 4-NF. São organismos gram-negativos, anaeróbios facultativos e reconhecidos como patógenos entéricos por apresentar vários fatores de virulência associados à doenças humanas (KIROV, 1993; BHOWMIK et al., 2009; EVANGELISTA-BARRETO et al., 2010; CAI et al., 2012; RODRIGUEZ-MORALES; CASTAÃEDA-HERNÃNDEZ, 2014). A abundância de Aeromonas em consórcios microbianos usados para degradação de surfactante aniônico já foi amplamente verificada (JIMENEZ et al., 1991; OKADA et al., 2014; DELFORNO et al., 2015; CENTURION et al., 2018), indicando que este gênero também pode ter atuado positivamente na degradação de 4-NF, apesar de tal fato ainda não ter sido descrito.

Para Pelobacter verificou-se aumento de cerca de $90 \%$ em sua abundância relativa após adição de 4-NF. São bactérias gram-negativas e anaeróbias estritas, utilizam compostos aromáticos (SCHINK; PFENNIG, 1982; CARMONA et al., 2009) ou álcoois (SCHINK, 1984) em ácido acético e $\mathrm{CO}_{2}$. Este gênero já foi relacionado com a degradação dos surfactantes Alquilbenzeno Linear Sulfonado (LAS) e Álcool Linear Etoxilado (LAE) em Reator Anaeróbio de Leito Fluidificado, semelhante ao usado neste trabalho (MOTTERAN et al., 2018).

Para Aquaspirillum verificou-se aumento em sua abundância relativa de cerca de $89 \%$ após adição de 4-NF, representando 2,96\% da abundância total. São organismos gram- 
negativos, aeróbios e oxidam ácidos orgânicos em $\mathrm{CO}_{2}$ (HYLEMON et al., 1973; KRIEG , 1981). A presença de organismos aeróbios pode estar relacionada às características operacionais do RALF, uma vez que este reator permite a entrada e oxigênio atmosférico no separador de fases e este é introduzido no sistema pela recirculação do efluente. A presença de ácidos orgânicos produzidos por organismos anaeróbios, aliada a introdução do oxigênio atmosférico subsidiou a ocorrência destes organismos.

Em relação a Pseudomonas verificou-se cerca de $46 \%$ de aumento em sua abundância relativa após adição de 4-NF. São bactérias aeróbias e facultativas, gram-negativas, presentes em diversos habitats e oxidam ampla diversidade de substratos (STARR et al., 1981; KRIEG et al., 2010); como corantes (KALYANI et al., 2008), herbicidas (MANDELBAUM; ALLAN; WACKETT, 1995), benzeno (DALVI et al., 2012); tolueno e xileno (SEYFRIED et al., 1994); nonilfenol etoxilado (BERTIN et al., 2007; DE WEERT et al., 2011; RUIZ et al., 2013; BAI et al., 2017) e outros compostos aromáticos (Naftaleno, Fenantreno, Bifenila, Octano e fenol) (PLOTNIKOVA et al., 2001). Representantes desse gênero também já foram amplamente relatadas com responsáveis pela degradação de surfactante aniônico em consórcios microbianos (ALMENDARIZ et al., 2001; OKADA et al., 2014; MACEDO et al., 2015; ANDRADE et al., 2017; DELFORNO et al., 2017, 2019; CENTURION et al., 2018) e culturas puras (LIJUN et al., 2005).

Bertin et al. (2007) avaliaram a degradação de NFe em reatores aeróbios com células imobilizadas em diferentes materiais suporte (sílica, carvão ativado e esferas de vidro), inoculados com culturas puras de Pseudomonas; para as concentrações afluente de 30 a $90 \mathrm{mg}$ $\mathrm{L}^{-1}$ foram verificadas eficiências de 77 a 99\%. Bai et al. (2017) utilizaram consórcio microbiano facultativo para biodegradação de Nonilfenol etoxilado $\left(1000 \mathrm{mg} \mathrm{L}^{-1}\right)$ e obtiveram eficiência de remoção de 75,61\% em 48 horas. Na caracterização microbiana deste consórcio verificaram elevada abundância relativa de Pseudomonas (15,33\%). Conforme autores supracitados, é evidente a participação deste gênero na degradação do surfactante NFe e seu subproduto 4-NF, como verificado no presente estudo.

Observou-se para Delftia aumento da abundância relativa de $98 \%$ após adição de 4-NF, representando $2,15 \%$ do total de sequências identificadas. São bactérias aeróbias gramnegativas e oxidam variedade de ácidos orgânicos, hidrocarbonetos e compostos aromáticos (SHIGEMATSU et al., 2003; BILGIN et al., 2015). Okada et al. (2014) identificaram representantes deste gênero em reatores contínuos usados na degradação de surfactante aniônico. 
Para Acinetobacter verificou-se aumento de $98 \%$ em sua abundância após adição de 4NF. Este gênero é constituído de organismos aeróbios gram-negativo (DI CELLO et al., 1997). Oxidam alcanos (VANEECHOUTTE et al., 2009), nonilfenol (CHANG; CHIANG; YUAN, 2005), hidrocarbonetos e demais compostos provenientes de contaminação por combustíveis (FONDI et al., 2016), benzoato, p-hidroxibenzoato, ácido mandélico, quinato e triptofano (BRENNER; KRIEG; STALEY, 2005a). A capacidade de degradação de surfactante aniônico também já foi amplamente relatada (ABBOUD et al., 2007; OKADA et al., 2014; DELFORNO et al., 2015, 2019; ANDRADE et al., 2017), indicando que o gênero Acinetobacter também pode estar relacionado com a degradação de 4-NF.

Chang, Chiang e Yuan (2005), avaliaram a degradação anaeróbia de Nonilfenol em digestores de lodo operados em batelada (por 80 dias) com adição de $5 \mathrm{mg} \mathrm{L}^{-1}$ de Nonilfenol. Bactérias semelhantes a Acinetobacter foram isoladas em condições com maiores taxas de degradação $\left(0,047\right.$ a $\left.0,009 \mathrm{~L} \mathrm{dia}^{-1}\right)$.

Em relação a Arcobacter verificou-se aumento de $30 \%$ em sua abundância relativa após a adição de 4-NF. São bactérias gram-negativas e anaeróbias facultativas (HOUF et al., 2005), consomem apenas compostos intermediários do ciclo do ácido tricarboxílico sem geração de subprodutos ácidos ou neutros (BRENNER; KRIEG; STALEY, 2005a). O aumento de sua abundância pode ter sido consequência do aumento de outros gêneros relacionados ao ciclo de Krebs, disponibilizando substratos para sua manutenção no reator. Sua presença também já foi verificada em reatores contínuos EGSB usados na degradação biológica de surfactante aniônico (DELFORNO et al., 2012).

Verificou-se para Ignavibacterium aumento em sua abundância relativa de cerca de $82 \%$ após adição de 4-NF. São bactérias anaeróbias facultativas e gram-negativas (IINO et al., 2010), utilizam açúcares com única fonte de carbono para geração de acetato como produto final (LIU et al., 2012). Sua identificação já foi verificada em reator contínuo usado na degradação simultânea de surfactante aniônico LAS e não iônico LAE (MOTTERAN et al., 2018).

Em relação a Treponema verificou-se aumento de $76 \%$ da abundância relativa após a adição de 4-NF. Organismos deste gênero são gram-negativos e apresentam metabolismo anaeróbio estrito. Fermentam ácidos graxos de cadeia longa, carboidratos e amino ácidos, e produzem álcoois, ácido acético e lático. Apresentam resistência a compostos bactericidas e são patogênicos a humanos (STARR et al., 1981; KRIEG et al., 2010).

Para Lysinibacillus verificou-se aumento na abundância relativa de cerca de 93\% após adição de 4-NF. São organismos gram-positivos e anaeróbios estritos. Representantes deste gênero foram propostos por Ahmed et al. (2007) como uma reclassificação de espécies do 
gênero Bacillus. Oxidam açúcares e ampla variedade de ácidos orgânicos (AHMED et al., 2007; VOS et al., 2009), além de biopolímeros (Xylan) (LEE et al., 2010).

Para Enterococcus verificou-se aumento de $98 \%$ da abundância relativa após a adição de 4-NF. Organismos deste gênero são gram-positivos e apresentam metabolismo anaeróbio facultativo (KAPATRAL et al., 2002; WOLF et al., 2004). Representantes desse gênero fermentam ampla diversidade de açúcares e carboidratos, produzindo principalmente lactato, além piruvato e etanol (VOS et al., 2009; RAMSEY; HARTKE; HUYCKE, 2014). Representantes de Enterococcus são intrinsicamente resistentes a cefalosporinas, lincosamidas, L-lactâmicos e baixos níveis de aminoglicosídeo; além disso, adquiriram determinantes genéticos que conferem resistência a todas as classes de antimicrobianos, incluindo cloranfenicol, tetraciclinas e glicopeptídeos. O maior risco relacionado a esses últimos traços de resistência, são os genes que codificam essas características de resistência a antibióticos, que podem ser transferidos a outros organismos por plasmídeos ou conjugados (GIRAFFA G., 2002). As características de resistência de Enterococcus a diversos agentes microbianos, relacionado ao aumento de sua abundância relativa no RALF após adição de 4-NF pode sugerir que este gênero também possui imunidade frente a toxicidade do 4-Nonilfenol.

Em relação às arqueias metanogênicas foi verificada abundância relativa de 2,58\% após a adição de 4-NF para Methanosaeta, o que representou aumento de cerca de $43 \%$ em relação a fase sem adição de 4-NF. São organismos estritamente anaeróbios e somente utilizam acetato como substrato para produção de metano (BOONE; WHITMAN; ROUVIERE, 1993). O aumento da abundância deste gênero pode estar relacionado a diversidade de organismos produtores de acetato; provavelmente a maior disponibilidade deste substrato favoreceu aumento dessa população.

De modo geral pode-se constatar ampla alteração da comunidade microbiana estabelecida no leito de areia do RALF após adição de 4-NF (Fase III) ao meio reacional, levando a seleção de organismos amplamente relacionados à degradação de compostos aromáticos (Geothrix, Holophaga, Aeromonas, Pelobacter, Aquaspirillum, Pseudomonas e Delftia).

Em relação ao leito com aspecto granular (Grânulos) formado sobre o leito de areia da Fase III, verificou-se distinta composição na comunidade microbiana. Para avaliar a diferenciação, foram selecionados os 20 gêneros mais abundantes na amostra do leito de areia da Fase III e do leito com aspecto granular (Grânulos). A comparação entre os gêneros mais 
abundantes para a amostra Fase III (em tons de azul) e Grânulos (em tons de vermelho) pode ser verificada na representação circular da Figura 5.52.

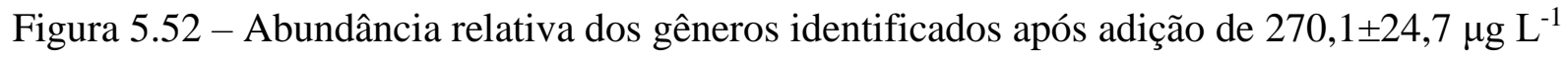
4-Nonilfenol para amostra do Leito de Areia (Areia, Fase III) e no Leito com aspecto granular (Grânulos, Fase III).

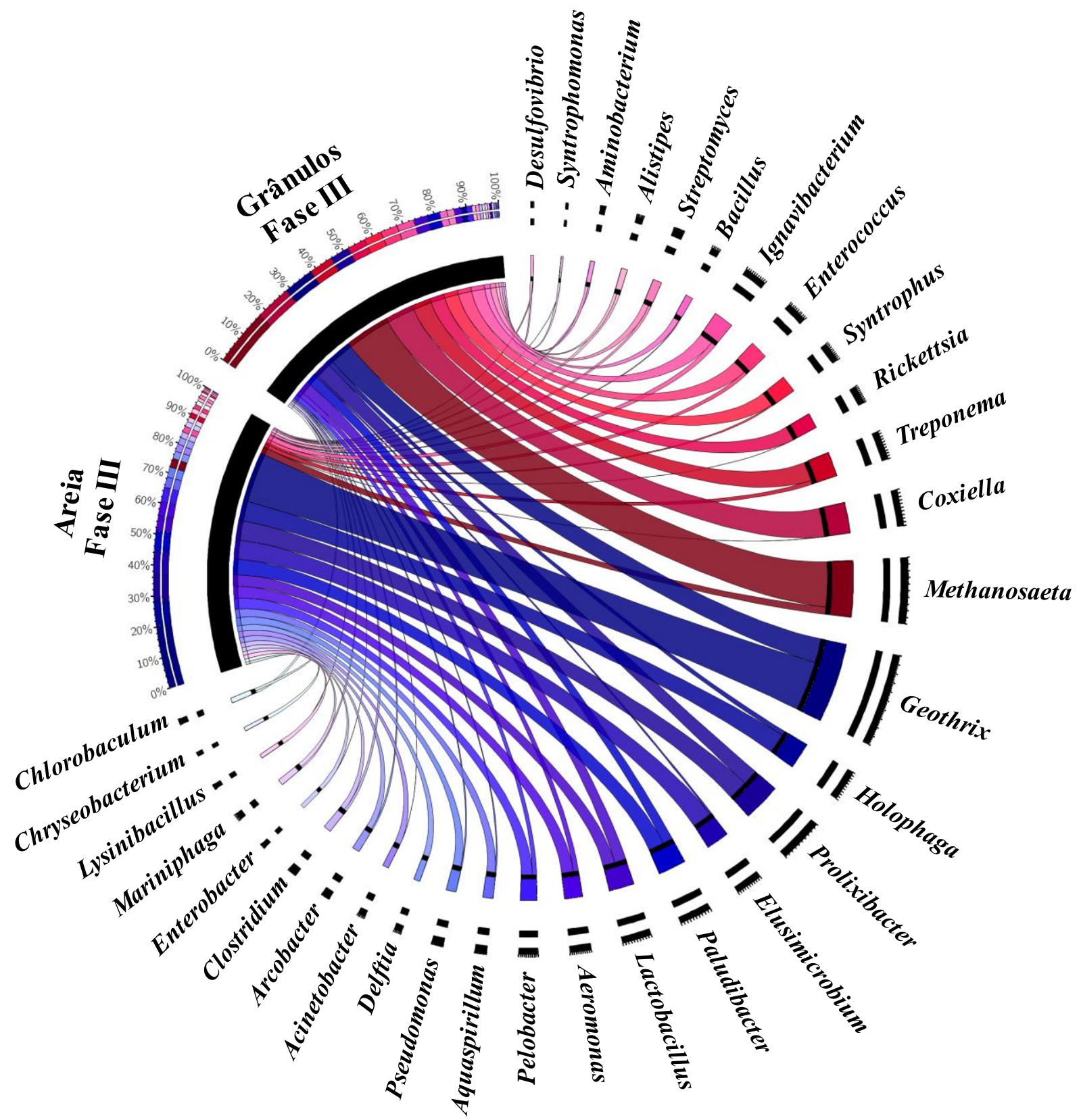

Fonte: $\mathrm{O}$ autor.

A representação circular da Figura 5.52 foi confeccionada com o total de 32 gêneros, sendo que cada um deles foi o mais abundante em uma das amostras. Por meio do perfil de cores da representação circular Figura 5.52, pode-se verificar que a comunidade microbiana do 
leito com aspecto granular foi extremamente diferente do leito de areia. Dentre os dez gêneros mais abundantes identificados na amostra do leito de areia, apenas Geothrix e Prolixibacter compuseram os dez gêneros mais abundantes da amostra dos grânulos.

Verificou-se que o gênero dominante identificado no leito com aspecto granular foi Methanosaeta (15,65\%), com abundância relativa $84 \%$ maior do que a verificada no leito de areia (2,56\%). Organismos representantes do gênero Methanosaeta são anaeróbios estritos e exclusivamente acetoclástica (PATELL; SPROTT, 1990; BOONE; WHITMAN; ROUVIERE, 1993; SMITH; INGRAM-SMITH, 2007). Sua ocorrência no leito com aspecto granular pode estar relacionada às características hidrodinâmicas deste, uma vez que a gradual perda de carga do fluxo ascendente permite a formação de zona com menor cisalhamento e, consequentemente o espessamento do biofilme. Aliado a isto, a abundância de gêneros relacionados à produção de ácido acético no leito de areia (Geothrix, Holophaga, Elusimicrobium, Paludibacter, Pelobacter, Syntrophus, Ignavibacterium, Treponema) pode ter subsidiado a ocorrência de Methanosaeta. A identificação de alta abundância relativa $(15,65 \%)$ para este gênero (Methanosaeta) no leito com aspecto granular (Grânulos) corrobora os dados de MEV (Figura 5.27 e 5.30), onde foi verificada morfologia com arranjo em feixes segmentados, característicos de Methanosaeta (BUZZINI et al., 2006)

Verificou-se para Coxiella abundância relativa 99\% maior no leito com aspecto granular (Grânulos), em comparação ao leito de areia. Organismos deste gênero são parasitas obrigatórios, tendo seu ciclo de vida limitado a condições intracelulares de células eucariontes (BRENNER; KRIEG; STALEY, 2005). Os gêneros identificados neste trabalho pertencem, exclusivamente, ao domínio Archaea ou Bacteria, portanto procariontes. Para Rickettsia também foi verificada abundância relativa $99 \%$ maior no leito com aspecto granular (Grânulos) em relação ao leito de areia. Trata-se também de parasita obrigatório de células eucariontes (BRENNER; KRIEG; STALEY, 2005). Não há relatos a respeito de organismos semelhantes a Coxiella e Rickettsia que crescem de forma livre ou parasitando organismos procariontes.

Para Treponema verificou-se abundância relativa $80 \%$ maior no leito com aspecto granular (Grânulos), em relação ao leito de areia. São bactérias gram-negativas e anaeróbias estritas, fermentam ácidos graxos de cadeia longa, carboidratos e amino ácidos, e produzem álcoois, ácido acético e lático, além de apresentar alta resistência a antibióticos (STARR et al., 1981; KRIEG et al., 2010).

Para Syntrophus verificou-se abundância de $90 \%$ maior no leito com aspecto granular do que no leito de areia. Organismos deste gênero são gram-negativos e apresentam 
metabolismo anaeróbio estrito (BRENNER; KRIEG; STALEY, 2005). São geralmente encontrados em sintrofismo com organismos metanogênicos (PERKINS; SCALFONE; ANGENENT, 2011). Fermentam ácidos orgânicos e compostos aromáticos (benzoato e toluato), além de polímeros termoplásticos (Polietileno tereftalato), formando ácido acético (NARIHIRO et al., 2015).

Verificou-se para representantes de Enterococcus, abundância relativa 76\% maior no leito com aspecto granular, em comparação ao leito de areia após a adição de 4-NF (Fase III). São bactérias gram-positivas e anaeróbias facultativas (KAPATRAL et al., 2002; WOLF et al., 2004), fermentam ampla variedade de substratos e geram ácido lático como principal produto (VOS et al., 2009; RAMSEY; HARTKE; HUYCKE, 2014), além de apresentarem espécies patogênicas com alta resistência a antibióticos (GIRAFFA G., 2002).

Para Ignavibacterium verificou-se abundância relativa de $65 \%$ maior no leito com aspecto granular, em comparação ao leito de areia. Organismo deste gênero possuem metabolismo anaeróbio facultativo e estrutura gram-negativa (IINO et al., 2010). Utilizam açúcares com única fonte de carbono para geração de acetato como produto final (LIU et al., 2012). Sua ocorrência já foi verificada em reator contínuo usado na degradação simultânea de surfactante aniônico LAS e não iônico LAE (MOTTERAN et al., 2018).

Em relação a Bacillus verificou-se abundância relativa de $87 \%$ maior no leito com aspecto granular, em comparação ao leito de areia. Representantes deste gênero são extremamente versáteis e podem ser identificados nos mais diferentes compartimentos ambientais. Pode apresentar metabolismo aeróbio, anaeróbio facultativo ou anaeróbio estrito. A estrutura de sua parede celular pode ser gram-positiva ou gram-negativa. Também utilizam ampla variedade de substratos, incluindo compostos fenólicos (VOS et al., 2009).

Para representantes semelhantes a Streptomyces verificou-se abundância relativa 58\% maior no leito com aspecto granular, em comparação ao leito de areia. Tais bactérias possuem estrutura gram-positiva e utilizam açúcares como fonte de carbono (STARR et al., 1981). Representantes desse gênero são responsáveis pela maior produção de antibióticos do mundo (WATVE et al., 2001; HOSHINO et al., 2015). A ocorrência de Streptomyces sugere antagonismo com Enterococcus e Treponema. Enquanto uma é responsável pela produção de antibióticos (Streptomyces), outras possuem alta resistência a estes (Enterococcus e Treponema).

Para representantes semelhantes a Alistipes verificou-se abundância relativa $12 \%$ maior no leito com aspecto granular, em comparação ao leito de areia. Este gênero é composto por organismos gram-negativos anaeróbios estritos. O principal produto gerado a partir da 
fermentação de carboidratos é ácido succínico (KRIEG et al., 2010). O ácido succínico é intermediário do ciclo do ácido tricarboxílico e pode ser metabolizado por outros organismos, como representantes de Arcobacter, o qual foi verificada abundância relativa de 1,99\% no leito de areia e 0,49\% para o leito com aspecto granular (Grânulos). Organismos similares a Arcobacter consomem apenas compostos intermediários do ciclo do ácido tricarboxílico, sem geração de subprodutos ácidos ou neutros (BRENNER; KRIEG; STALEY, 2005a)

Para representantes semelhantes a Aminobacterium verificou-se abundância relativa de 47\% maior no leito com aspecto granular, em comparação ao leito de areia. Composto por organismos anaeróbios estritos e com estrutura celular gram-negativa (BAENA et al., 1998), fermentam amino ácidos e ácidos orgânicos (CHERTKOV et al., 2010). Sua presença já foi verificada em reator contínuo usado na degradação simultânea de surfactantes aniônico e não iônico (MOTTERAN et al., 2018).

Em relação a Syntrophomonas verificou-se abundância relativa de 93\% maior no leito com aspecto granular, em comparação ao leito de areia. São organismos com metabolismo anaeróbio e estrutura celular gram-negativa. Realizam a $\beta$-oxidação de ácidos graxos, formado $\mathrm{H}_{2}$. Sua presença geralmente ocorre em sintrofismo com organismos metanogênicos hidrogenotróficos (VOS et al., 2009). No leito com aspecto granular foram identificados organismos similares a Methanobacterium com abundânica relativa de 0,12\%; este gênero é constituído por arqueia metanogênicas hidrogênotróficas (BOONE; WHITMAN; ROUVIERE, 1993), indicando possível sintrofismo entre Syntrophomonas e Methanobacterium. A presença deste gênero (Syntrophomonas) já foi relatada em reatores contínuos usados na degradação do surfactante aniônico Alquilbenzeno Linear Sulfonado (LAS) (DELFORNO et al., 2015).

A abundância de representantes do gênero Desulfovibrio foi de $37 \%$ maior no leito com aspecto granular, em comparação ao leito de areia. São organismos anaeróbios gram-negativos, que utilizam sulfato como aceptor de elétrons, promovendo a oxidação incompleta de lactato a acetato (BRENNER; KRIEG; STALEY, 2005). Representantes desse gênero são particularmente importantes na degradação do surfactante aniônico LAS e sua presença já foi amplamente relatada (OKADA et al., 2014; BRAGA et al., 2015; DELFORNO et al., 2015, 2017; MACEDO et al., 2015; ANDRADE et al., 2017; MOTTERAN et al., 2018; DELFORNO et al., 2019), uma vez que pode estar envolvido na etapa de desulfonação, que consiste na remoção de compostos de enxofre de compostos alifáticos e aromáticos.

Por meio da caracterização microbiana do leito de areia e leito com aspecto granular foi possível verificar que após a adição de 4-NF houve predominância de gêneros amplamente 
associados a capacidade de degradar compostos aromáticos, a saber, em ordem de abundância relativa: Geothrix, Holophaga, Aeromonas, Pelobacter, Aquaspirillum, Pseudomonas e Delftia.

Para muitos gêneros que foi observado aumento da abundância relativa após a adição de 4-NF também estão relacionados a degradação de surfactante aniônico, como Geothrix, Holophaga, Aeromonas, Pelobacter, Pseudomonas, Delftia, Acinetobacter, Arcobacter, Ignavibacterium, indicando que a degradação simultânea destes compostos (LAS e 4-NF) pode ser viável.

Após adição de 4-NF ao meio reacional também houve aumento na abundância relativa organismos com conhecida resistência a antibióticos, similares aos gêneros: Treponema e Enterococcus.

A comparação entre a composição da comunidade microbiana do leito de areia e do leito com aspecto granular possibilitou inferir que a configuração reacional promoveu estratificação da biomassa. No leito de areia foram verificados desde organismos aeróbios a anaeróbios estritos, com predominância de gêneros relacionados a hidrólise, acidogênese e acetogênese, etapas iniciais da degradação anaeróbia. No leito com aspecto granular predominaram organismos estritamente anaeróbios relacionados com a acetogênese e metanogênese.

\subsubsection{2 Índices de Diversidade}

Os índices de diversidade das amostras referentes ao sequenciamento massivo do gene RNAr 16S foram calculados individualmente para os domínios Archaea e Bacteria e sua discussão realizada nos itens seguintes.

\subsubsection{Domínio Bacteria}

Em relação aos índices de diversidade para domímio Bacteria das amostras de sequenciamento massivo do gene RNAr 16S via plataforma Illumina-MiSeq ${ }^{\circledR}$, observou-se maior diversidade $(4,09)$ e distribuição uniforme das comunidades (equitabilidade $=0,7517$ ) para a amostra do Inóculo, o que resultou também no menor índice de dominância $(0,02973)$; e riqueza $(235,1)$. A maior riqueza $(250,6)$ e dominância $(0,05989)$ foram verificadas para a amostra da Fase I (sem adição de 4-NF). Os valores referentes aos índices de diversidade para o Domínio Bacteria podem ser verificados na Tabela 5.24. 
Tabela 5.24 - Índices de diversidade para o Domínio Bacteria via plataforma Illumina-MiSeq ${ }^{\circledR}$.

\begin{tabular}{lcccc}
\hline \multicolumn{1}{c}{ Índice } & Inóculo & Fase I & Fase III & Grânulo \\
\hline Dominância & 0,02973 & 0,05989 & 0,04937 & 0,04382 \\
Diversidade & 4,09 & 3,80 & 3,82 & 3,84 \\
Equitabilidade & 0,7517 & 0,6913 & 0,6991 & 0,7052 \\
Riqueza & 235,1 & 250,6 & 238,2 & 242,0 \\
\hline
\end{tabular}

Para a amostra do Inóculo verificou-se a maior diversidade e a menor riqueza; isto pode ser explicado devido ao fato que o índice de riqueza Chao-1 expressa, basicamente, o número de espécies, enquanto o índice de diversidade Shannon é sensível a abundância das espécies (FREITAS; MAGALHÃES, 2012).

A adição de 4-NF no reator (Fase III) provocou redução de 5\% (de 250,6 para 238,2) no índice de riqueza (Chao-1), em comparação a amostra do reator na fase sem adição de 4-NF (Fase I), todavia, verificou-se modesto aumento no índice de diversidade (de 3,80 para 3,82). A comparação entre os índices de riqueza e diversidade para domínio Bacteria podem ser verificadas na Figura 5.53.

Figura 5.53 - Variação dos Índices de diversidade e riqueza para o Domínio Bacteria.

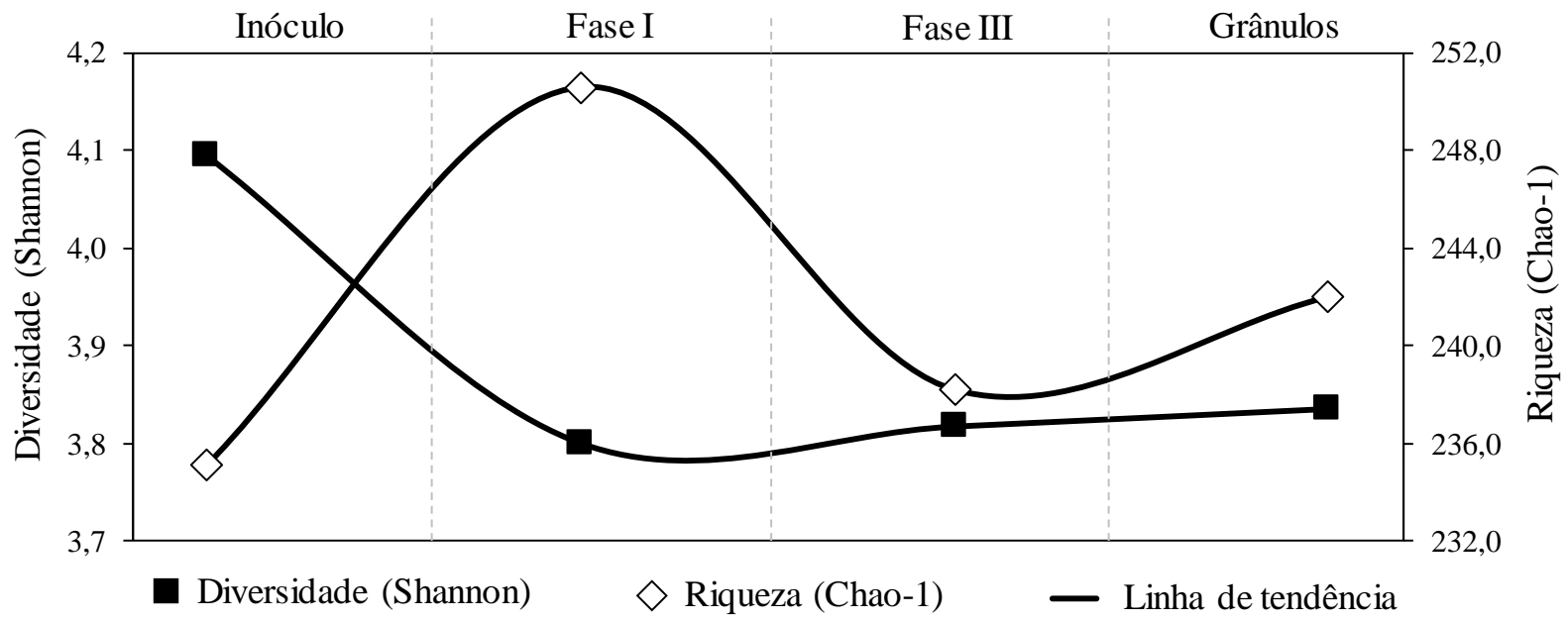

Fonte: O autor.

Houve sutil aumento de 1,1\% (de 0,6913 para 0,6991) do índice de equitabilidade após a adição de 4-NF no reator (Fase III), em comparação a fase controle (Fase I). Provavelmente, seguida da supressão de gêneros devido ao efeito tóxico do 4-NF (Fase III), houve a adaptação 
da comunidade e aumento da abundância de organismos com ferramental metabólico para degradação de 4-NF, o que explicaria o aumento da diversidade e equitabilidade.

De forma geral, a dominância de organismos do domínio Bacteria no RALF teve comportamento antagônico à diversidade. Assim, a redução da diversidade (Fase I) ocasionou aumento da dominância. O comportamento dos índices de diversidade e dominância pode ser verificado na Figura 5.54.

Figura 5.54 - Variação dos Índices de diversidade e dominância para o Domínio Bacteria.

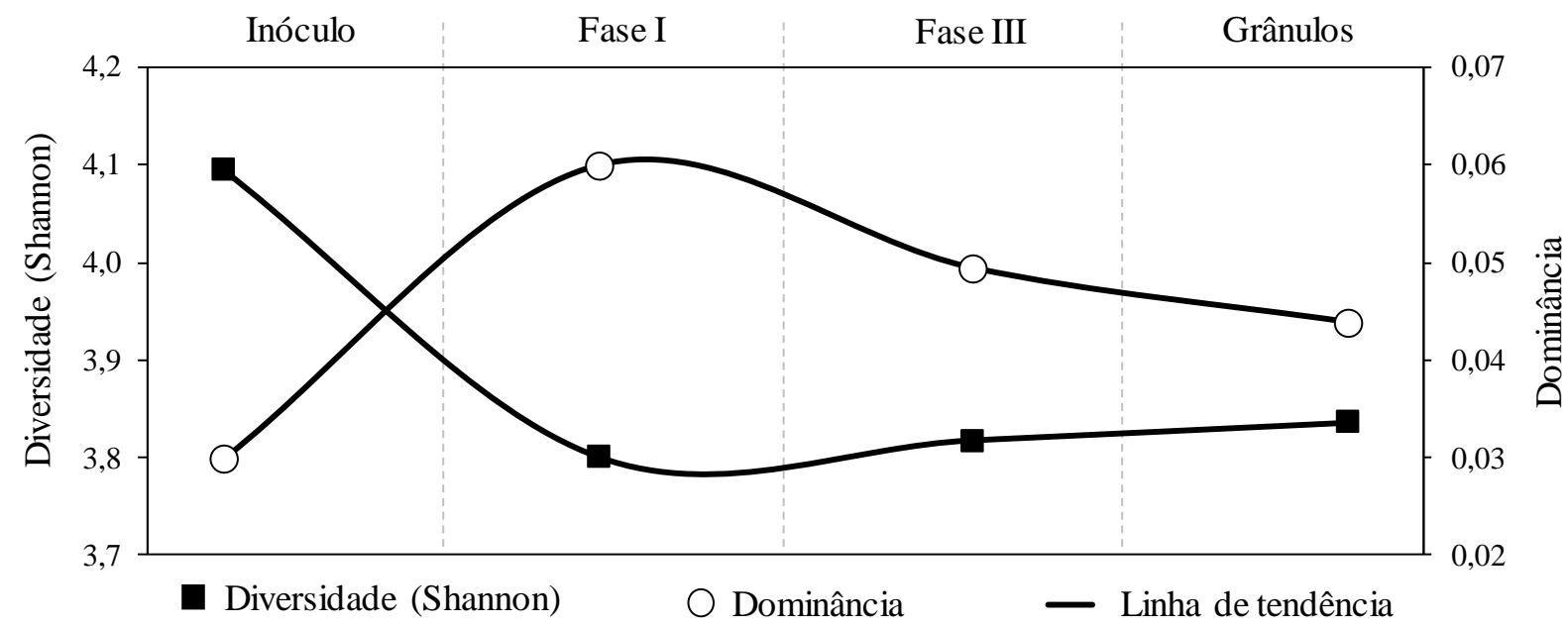

Fonte: $\mathrm{O}$ autor.

\subsubsection{Domínio Archaea}

Em relação aos índices de diversidade do domínio Archaea para amostras de sequenciamento massivo $16 \mathrm{~S}$, para amostra referente ao Inóculo não foram verificados os maiores índices de diversidade $(1,12)$ e equitabilidade $(0,4952)$. A maior diversidade $(1,51)$ e equitabilidade $(0,5872)$ ocorreram para a Fase I. Os valores referentes aos índices de diversidade para o Domínio Archaea nas amostras do sequenciamento massivo 16S podem ser verificados na Tabela 5.25 . 
Tabela 5.25 - Índices de diversidade para o Domínio Archaea via plataforma Illumina-MiSeq ${ }^{\circledR}$.

\begin{tabular}{lcccc}
\hline \multicolumn{1}{c}{ Índice } & Inóculo & Fase I & Fase III & Grânulo \\
\hline Dominância & 0,4932 & 0,3322 & 0,7796 & 0,9472 \\
Shannon & 1,12 & 1,51 & 0,56 & 0,18 \\
Equitabilidade & 0,4252 & 0,5872 & 0,2422 & 0,0753 \\
Riqueza & 14 & 14 & 10 & 11 \\
\hline
\end{tabular}

A adição de 4-NF ao reator (Fase III) ocasionou redução da riqueza (de 14 para 10), diversidade (de 1,51 para 0,56), equitabilidade (de 0,5872 para 0,2422) e aumento da dominância (de 0,3322 para 0,7796) para o domínio Archaea. A variação dos índices de riqueza e diversidade para o domínio Archaea pode ser verificada na Figura 5.53.

Figura 5.55 - Variação dos Índices de diversidade e riqueza para o Domínio Archaea.

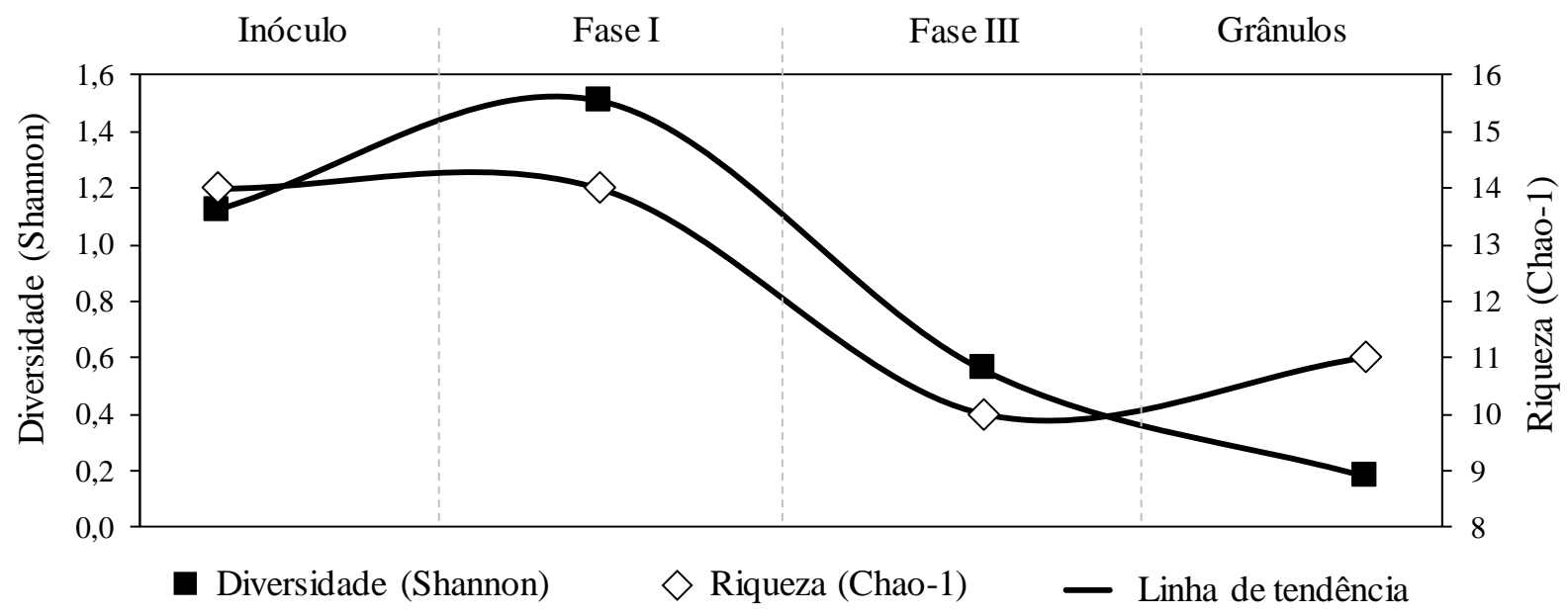

Fonte: $\mathrm{O}$ autor.

Houve redução do índice de equitabilidade (de 0,5872 para 0,2422) após adição de 4NF (Fase III), em comparação a fase controle (Fase I), indicando que a presença de 4-NF reduziu a uniformidade da distribuição dos indivíduos (equitabilidade). Ao mesmo tempo que o 4-NF possui efeito tóxico a determinados gêneros, outras são favorecidas, o que explica a variação da equitabilidade e consequente aumento de no índice de dominância.

Para o domínio Archaea, a dominância teve comportamento antagônico a diversidade e similar ao verificado anteriormente para o domínio Bacteria. Deste modo, o aumento da 
diversidade (Fase I) provocou redução da dominância e vice-versa. O comportamento dos índices de diversidade e dominância pode ser verificado na Figura 5.56.

Figura 5.56 - Variação dos Índices de diversidade e riqueza para o Domínio Archaea em amostras de sequenciamento massivo $16 \mathrm{~S}$ via plataforma Illumina-MiSeq ${ }^{\circledR}$.

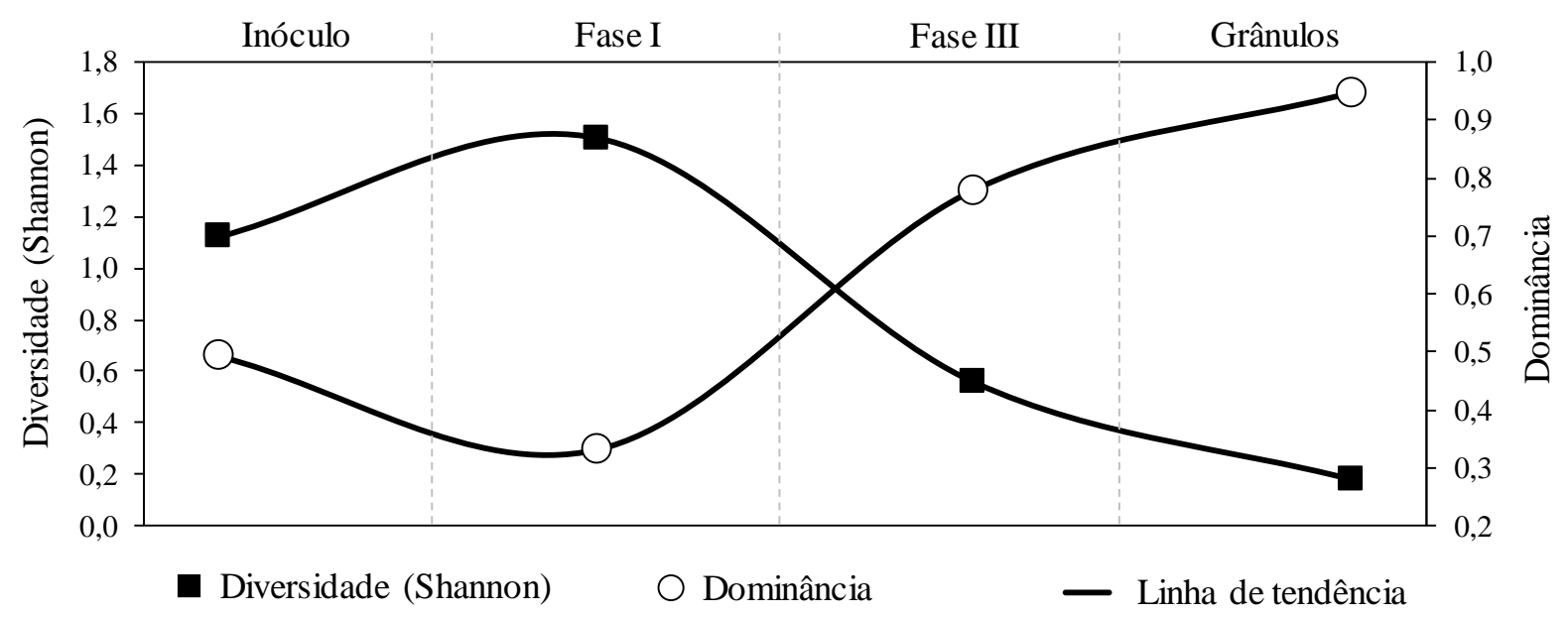

Fonte: $\mathrm{O}$ autor.

O maior valor para o índice de dominância $(0,9472)$ foi verificado para a amostra referente ao leito com aspecto granular (Grânulos), o que pode estar relacionado a ocorrência de arqueias metanogênicas, identificadas com abundância relativa de 15,65\% e semelhantes a Methanosaeta. 


\section{CONSIDERAÇÕES FINAIS}

De acordo com as hipóteses propostas no item 2 (Hipóteses e objetivos), as considerações finais deste estudo foram dispostas na forma de tabela (Tabela 6.1), bem como a situação (aceita ou refutada) de cada.

Tabela 6.1 - Situação das hipóteses do presente estudo.

Hipótese

Situação

Hipótese Por meio da aplicação do Reator Anaeróbio de Leito Fluidificado geral (RALF) com leito de areia será obtida a degradação e remoção de 4Nonilfenol (4-NF) em meio de cultura.

Hipótese A concentração de NF afluente não afetará a eficiência de degradação I da matéria orgânica.

Hipótese As diferentes concentrações de 4-NF aplicadas ao RALF ocasionarão II seleção dos microrganismos que compõem sua biomassa.

Hipótese Em função da concentração de 4-NF poderá ocorrer a inibição da III metanogênese e redução da eficiência de remoção de matéria orgânica.

Hipótese A adição de co-substrato ao meio de cultura pode contribuir para IV estabelecer comunidade microbiana degradadora de 4-NF.

Hipótese A comunidade microbiana do RALF pode degradar 4-NF em meio de V cultura sem adição de co-substrato.

Hipótese

A técnica de Cromatografia Líquida de Alta Eficiência (HPLC) pode VI ser empregada para identificação de 4-NF em estações de tratamento de águas residuárias.

- Aceita; X - Refutada.

A Hipótese III foi refutada, uma vez que não houve inibição da produção de metano nas concentrações testadas, tanto para ensaios em batelada quanto em reator contínuo RALF. Além disso, foi constatada dominância de arqueias metanogênicas similares a Methanosaeta, no leito com aspecto granular, indicando que a presença de 4-NF não prejudicou estas populações. 


\section{CONCLUSÕES}

A técnica de Cromatografia Líquida de Alta Eficiência (HPLC) permitiu a quantificação de 4-NF, atendendo aos parâmetros de qualidade quanto a linearidade da curva analítica, seletividade, limite de detecção, limite de quantificação e recuperação.

No método desenvolvido obteve-se, para 4-NF, cromatograma com um pico bem definido, sem interferente da matriz. As melhores condições cromatográficas foram, a saber, coluna C-8 (Agilent ${ }^{\circledR}$ ), temperatura de $40^{\circ} \mathrm{C}$, volume de injeção de $100 \mu \mathrm{L}$, fluxo de eluição de 0,8 $\mathrm{mL} \mathrm{min}^{-1}$, acetonitrila/água na proporção de 90:10 (v/v) como fase móvel e e comprimentos de onda para o detector de fluorescência de $\lambda_{\mathrm{exc}}=225 \mathrm{~nm}$ e $\lambda_{\mathrm{em}}=305 \mathrm{~nm}$.

A adição de 4-NF em reatores em batelada aumentou a produção de metano acumulada para todos os co-susbtratos testados, todavia, retardou o tempo de início da produção e reduziu a velocidade de produção. Os maiores valores de produção acumulada e eficiência de remoção de DQO foram verificados em ensaios com adição de fumarato, enquanto para a remoção de 4NF os ensaios não diferiram significativamente.

A adição de 4-NF ao RALF não afetou a eficiência de remoção de DQO nem o tamponamento do sistema.

As diferentes concentrações de 4-NF aplicadas ao RALF ocasionaram a seleção dos microrganismos que compõem sua biomassa, tanto para domínio Archaea quanto para Bacteria.

O acréscimo de co-substrato (etanol) ao meio de cultura aliado a adição de concentrações crescentes de 4-NF foi estratégia eficaz para estabelecer consórcio microbiano em RALF com capacidade de degradação deste contaminante.

A comunidade microbiana estabelecida em RALF pode degradar 4-Nonilfenol em meio de cultura sem adição de co-substrato, após prévia adaptação.

Os principais gêneros relacionados a degradação de 4-NF foram Geothrix, Holophaga, Elusimicrobium, Paludibacter, Lactobacillus, Aeromonas, Pelobacter, Aquaspirillum, Pseudomonas, Delftia, Acinetobacter, Arcobacter, Ignavibacterium, Treponema, Lysinibacillus e Enterococcus. 


\section{SUGESTÕES PARA TRABALHOS FUTUROS}

Avaliar a remoção e biodegradação simultânea do Nonilfenol Etoxilado (NFe) e Alquilbenzeno Linear Sulfonado (LAS) em meio de cultura e caracterizar a comunidade microbiana estabelecida no biofilme do RALF e outras configurações reacionais (UASB e EGSB).

Caracterizar a comunidade microbiana com uso de tecnologias ômicas (metagenômica metabolômica, metratrascriptômica e metaproteômica).

Avaliar a concentração máxima de 4-NF que pode ser aplicada em RALF sem que haja redução da eficiência de remoção de DQO.

Avaliar os subprodutos da degradação do surfactante não iônico Nonilfenol Etoxilado (NFe) em reator RALF, como Nonilfenol mono-etoxilado, Nonilfenol poli-etoxilado, tertNonilfenol.

Monitorar a degradação de NFe em RALF na presença de outros co-susbtratos como fumarato, glicose e sacarose.

Avaliar a degradação de NFe em esgoto doméstico em co-digestão com água de lavanderia comercial em RALF em escala aumentada.

Avaliar a adsorção de 4-NF nos mais diversos materiais usando isotermas de adsorção.

Monitorar a degradação de 4-NF em meio sulfato-redutor, nitrificante e desnitrificante.

Verificar a mobilidade 4-NF para a fase líquida em degradação simultânea de LAS e NFe em reator RALF, UASB e EGSB. 


\section{REFERÊNCIAS}

ABBOUD, M. M. et al. Different optimization conditions required for enhancing the biodegradation of linear alkylbenzosulfonate and sodium dodecyl sulfate surfactants by novel consortium of Acinetobacter calcoaceticus and Pantoea agglomerans. Enzyme and Microbial Technology, v. 41, n. 4, p. 432-439, 2007.

AHEL, M. et al. Photochemical degradation of nonylphenol and nonylphenol polyethoxylates in natural waters. Chemosphere, v. 28, n. 7, p. 1361-1368, 1994.

AHEL, M.; GIGER, W.; SCHAFFNER, C. Behaviour of alkylphenol polyethoxylate surfactants in the aquatic environment-II. Occurrence and transformation in rivers. Water Research, v. 28, n. 5, p. 1143-1152, 1994.

AHMED, I. et al. Proposal of Lysinibacillus boronitolerans gen. nov. sp. nov., and transfer of Bacillus fusiformis to Lysinibacillus fusiformis comb. nov. and Bacillus sphaericus to Lysinibacillus sphaericus comb. nov. International Journal of Systematic and Evolutionary Microbiology, v. 57, n. 5, p. 1117-1125, 2007.

ALMENDARIZ, F. J. et al. Degradation of lineal alkylbenzene sulphonate (LAS) in an acidogenic reactor bioaugmented with a Pseudomonas aeruginosa (M113) strain. Water Science and Technology, v. 44, n. 4, p. 183-188, 2001.

ANDRADE, M. V. F. et al. Effects of hydraulic retention time, co-substrate and nitrogen source on laundry wastewater anionic surfactant degradation in fluidized bed reactors. Bioresource Technology, v. 224, p. 246-254, 2017. Disponível em: <http://dx.doi.org/10.1016/j.biortech.2016.11.001>.

ARAUJO, F. G. DE; BAUERFELDT, G. F. ;; CID, Y. P. Determination of 4-nonylphenol in surface waters of the Guandu river basin by high performance liquid chromatography with ultraviolet detection. Journal of the Brazilian Chemical Society, v. 00, n. 00, p. $1-8,2018$.

AREVALO, M.; AZCOITIA, I.; GARCIA-SEGURA, L. M. The neuroprotective actions of oestradiol and oestrogen receptors. Nature Publishing Group, v. 16, n. 1, p. 17-29, 2015. Disponível em: <http://dx.doi.org/10.1038/nrn3856>.

BAENA, S. et al. Aminobacterium colombiense gen. nov. sp. nov., an amino acid-degrading anaerobe isolated from anaerobic sludge. Anaerobe, v. 4, n. 5, p. 241-250, 1998.

BAI, N. et al. Nonylphenol biodegradation characterizations and bacterial composition analysis of an effective consortium NP-M2. Environmental Pollution, v. 220, p. 95-104, 2017. Disponível em: <http://dx.doi.org/10.1016/j.envpol.2016.09.027>.

BALAGUER, P. et al. Reporter cell lines to study the estrogenic effects of xenoestrogens. Science of the Total Environment, v. 233, n. 1-3, p. 47-56, 1999.

BARAHONA, F.; TURIEL, E.; MARTÍN-ESTEBAN, A. Determination of Nonylphenol and Nonylphenol Ethoxylates in Powdered Milk Infant Formula by HPLC-FL. Journal of Chromatographic Science, v. 49, n. March, p. 243-248, 2011. Disponível em: <http://chromsci.oxfordjournals.org/content/49/3/243.short>.

BECHI, N. et al. Environmental levels of para-nonylphenol are able to affect cytokine secretion in human placenta. Environmental Health Perspectives, v. 118, n. 3, p. 427-431, 2010. 
BEISEL, J.-N.; MORETEAU, J.-C. A simple formula for calculating the lower limit of Shannon's diversity index. Ecological Modelling, v. 99, p. 289-292, 1997.

BELLO, M. M.; RAMAN, A. A. A.; PURUSHOTHAMAN, M. Applications of fluidized bed reactors in wastewater treatment $-\mathrm{A}$ review of the major design and operational parameters. Journal of Cleaner Production, v. 141, p. 1492-1514, 2017. Disponível em: 〈http://dx.doi.org/10.1016/j.jclepro.2016.09.148>.

BENNIE, D. T. et al. Occurrence of alkylphenols and alkylphenol mono- and diethoxylates in natural waters of the Laurentian Great Lakes basin and the upper St. Lawrence River. Science of the Total Environment, v. 193, n. 3, p. 263-275, 1997.

BERTIN, L. et al. Biodegradation of polyethoxylated nonylphenols in packed-bed biofilm reactors. Industrial and Engineering Chemistry Research, v. 46, n. 21, p. 6681-6687, 2007.

BHOWMIK, P. et al. Pathogenic potential of Aeromonas hydrophila isolated from surface waters in Kolkata, India. Journal of Medical Microbiology, v. 58, n. 12, p. 1549-1558, 2009.

BILGIN, H. et al. Delftia acidovorans: A rare pathogen in immunocompetent and immunocompromised patients. Canadian Journal of Infectious Diseases and Medical Microbiology, v. 26, n. 5, p. 277-279, 2015.

BINA, B. et al. Determination of 4-NonylPhenol and 4-tert-octylphenol compounds in various types of wastewater and their removal rates in different treatment processes in nine wastewater treatment plants of Iran. Chinese Journal of Chemical Engineering, 2017. Disponível

em: <http://www.sciencedirect.com/science/article/pii/S1004954117301908>.

BOEKHORST, J. et al. The complete genomes of Lactobacillus plantarum and Lactobacillus johnsonii reveal extensive differences in chromosome organization and gene content. Outlooks on Pest Management, v. 26, n. 5, p. 207-210, 2015.

BONEFELD-JØRGENSEN, E. C. et al. Endocrine-disrupting potential of Bisphenol A, Bisphenol A dimethacrylate, 4-n-nonylphenol, and 4-n-octylphenol in vitro: New data and a brief review. Environmental Health Perspectives, v. 115, n. SUPPL1, p. 69-76, 2007.

BOONE, D. R.; WHITMAN, W. B.; ROUVIERE, P. Methanogenesis. [s.l: s.n.]

BRAGA, J. K. Caracterização microbiana e degradação de surfactante aniônico em reator anaeróbio de leito fluidificado com água residuária de lavanderia. 2014. Doutorado Universidade de São Paulo, 2014.

BRAGA, J. K. et al. Biodegradation of linear alkylbenzene sulfonate in commercial laundry wastewater by an anaerobic fluidized bed reactor. Journal of Environmental Science and Health - Part A Toxic/Hazardous Substances and Environmental Engineering, v. 50, n. 9, p. 946-957, 2015.

BRANDT, K.; BARRANGOU, R. Using glycolysis enzyme sequences to inform Lactobacillus phylogeny. Microbial Genomics, v. 4, n. 6, p. 1-13, 2018. Disponível em: $<$ http://www.microbiologyresearch.org/content/journal/mgen/10.1099/mgen.0.00018 $7>$.

BRASIL. PORTARIA Nº - 2.914, DE 12 DE DEZEMBRO DE 2011. Diário Oficial da União, 
v. 2011, p. 1-16, 2011a. Disponível em: <http://bvsms.saude.gov.br/bvs/saudelegis/gm/2011/prt2914_12_12_2011.html>.

BRASIL. RESOLUÇÃO No 430, DE 13 DE MAIO DE 2011. Dipario Oficial da União, p. 14$16,2011 b$.

BRENNER, D. J.; KRIEG, N. R.; STALEY, J. T. Bergeys's Manual of Systematic Bacteriology - The Proteobacteria Part C. [s.l: s.n.]v. 2

BRENNER, D. J.; KRIEG, N. R.; STALEY, J. T. Bergeys's Manual of Systematic Bacteriology - The Proteobacteria Part B. [s.l: s.n.]

BURGHATE, S. P.; INGOLE, N. W. Fluidized Bed Biofilm Reactor - A Novel Wastewater Treatment Reactor. International Journal of Research in Environmental Science and Technology, v. 3, n. 4, p. 145-155, 2013.

BUZZINI, A. P. et al. Evaluation of the microbial diversity in an UASB reactor treating wastewater from an unbleached pulp plant. Process Biochemistry, v. 41, n. 1, p. 168$176,2006$.

CAI, S.-H. et al. CHARACTERIZATION OF PATHOGENIC AEROMONAS VERONII BV. VERONII ASSOCIATED WITH ULCERATIVE SYNDROME FROM CHINESE LONGSNOUT CATFISH (LEIOCASSIS. Current Clinical Topics In Infectious Diseases, v. 189, n. 40, p. 75-78, 2012.

CANADÁ. Canadian water quality guidelines for the protection of aquatic life: Nonylphenol and its ethoxylates. Canadian Council of Ministers of the Environment, n. 1991, p. 1$8,2002$.

CARMONA, M. et al. Anaerobic Catabolism of Aromatic Compounds: a Genetic and Genomic View. Microbiology and Molecular Biology Reviews, v. 73, n. 1, p. 71-133, 2009. Disponível em: <http://mmbr.asm.org/cgi/doi/10.1128/MMBR.00021-08>.

CAROSIA, M. F. et al. Microbial characterization and degradation of linear alkylbenzene sulfonate in an anaerobic reactor treating wastewater containing soap powder. Bioresource Technology, v. 167, p. 316-323, 2014. Disponível em: <http://dx.doi.org/10.1016/j.biortech.2014.06.002>.

CENTURION, V. B. et al. Anaerobic co-digestion of commercial laundry wastewater and domestic sewage in a pilot-scale EGSB reactor: The influence of surfactant concentration on microbial diversity. International Biodeterioration and Biodegradation, v. 127, n. November 2017, p. 77-86, 2018. Disponível em: <https://doi.org/10.1016/j.ibiod.2017.11.017>.

CHEN, M. L. et al. Quantification of prenatal exposure and maternal-fetal transfer of nonylphenol. Chemosphere, v. 73, n. 1 SUPPL., 2008.

CHENG, Y. et al. Effects of 4-nonylphenol in drinking water on the reproductive capacity of Japanese quails (Coturnix japonica). Chemosphere, v. 175, p. 219-227, 2017. Disponível em: <http://dx.doi.org/10.1016/j.chemosphere.2017.02.041〉.

CHERNIAEV, A. P.; KONDAKOVA, A. S.; ZYK, E. N. Contents of 4-Nonylphenol in Surface Sea Water of Amur Bay (Japan/East Sea). Achievements in the Life Sciences, v. 10, n. $1, \quad$ p. 65-71, 2016. Disponível em: <http://linkinghub.elsevier.com/retrieve/pii/S2078152016300104>.

CHERNICHARO, C. A. de L. Reatores anaeróbios: princípios do tratamento biológico de águas residuárias. Belo Horizonte: UFMG, 2007. 
CHERTKOV, O. et al. Complete genome sequence of Aminobacterium colombiense type strain (ALA-1 T). Standards in Genomic Sciences, v. 2, n. 3, p. 280-289, 2010.

CLAESSON, M. J.; VAN SINDEREN, D.; O'TOOLE, P. W. Lactobacillus phylogenomics Towards a reclassification of the genus. International Journal of Systematic and Evolutionary Microbiology, v. 58, n. 12, p. 2945-2954, 2008.

COATES, J. D. et al. Geothrix ferrnentans gen. nov., sp. nov., a novel Fe(III)-reducing bacterium from a hydrocarbon-contaminated aquifer. International Journal of Systematic Bacteriology, v. 49, n. 1 999, p. 1615-1622, 1999.

CORSI, S. R. et al. Nonylphenol ethoxylates and other additives in aircraft deicers, antiicers, and waters receiving airport runoff. Environmental Science and Technology, v. 37, n. 18, p. 4031-4037, 2003.

CORVINI, P. F. X.; SCHÄFFER, A.; SCHLOSSER, D. Microbial degradation of nonylphenol and other alkylphenols - our evolving view. Appl Microbiol Biotechnol, p. 223-243, 2006.

CRUCERU, I. et al. HPLC-FLD determination of 4-nonylphenol and 4-tert-octylphenol in surface water samples. Environmental Monitoring and Assessment, v. 184, n. 5, p. 2783-2795, 2012.

DALVI, S. et al. Proteogenomic elucidation of the initial steps in the benzene degradation pathway of a novel halophile, Arhodomonas sp. strain rozel, isolated from a hypersaline environment. Applied and Environmental Microbiology, v. 78, n. 20, p. 7309-7316, 2012.

DANZO, B. J. Environmental xenobiotics may disrupt normal endocrine function by interfering with the binding of physiological ligands to steroid receptors and binding proteins. Environmental Health Perspectives, v. 105, n. 3, p. 294-301, 1997.

DE BRUIN, W. et al. Morphological characterisation of lettuce plasma membrane ultrastructure and vesicle formation caused by nonylphenol: A scanning electron microscopy study. South African Journal of Botany, v. 111, n. July, p. 176-181, 2017. Disponível em: <http://linkinghub.elsevier.com/retrieve/pii/S0254629916339618>.

DE WEERT, J. P. A. et al. Degradation of 4-n-nonylphenol under nitrate reducing conditions. Biodegradation, v. 22, n. 1, p. 175-187, 2011.

DEL NERY, V. et al. Poultry slaughterhouse wastewater treatment plant for high quality effluent. Water Science and Technology, v. 73, n. 2, p. 309-316, 2016.

DEL NERY, V. et al. Hydraulic and organic rates applied to pilot scale UASB reactor for sugar cane vinasse degradation and biogas generation. Biomass and Bioenergy, v. 119, $\mathrm{n}$. October, p. 411-417, 2018. Disponível em: <https://doi.org/10.1016/j.biombioe.2018.10.002>.

DELFORNO, T. P. et al. Microbial characterization and removal of anionic surfactant in an expanded granular sludge bed reactor. Bioresource Technology, v. 107, p. 103-109, 2012. Disponível em: <http://dx.doi.org/10.1016/j.biortech.2011.12.042>.

DELFORNO, T. P. et al. Microbial diversity and the implications of sulfide levels in an anaerobic reactor used to remove an anionic surfactant from laundry wastewater. Bioresource Technology, v. 192, p. 37-45, 2015. Disponível em: <http://dx.doi.org/10.1016/j.biortech.2015.05.050>. 
DELFORNO, T. P. et al. Metagenomic analysis of the microbiome in three different bioreactor configurations applied to commercial laundry wastewater treatment. Science of the Total Environment, v. 587-588, p. 389-398, 2017. Disponível em: <http://dx.doi.org/10.1016/j.scitotenv.2017.02.170>.

DELFORNO, T. P. et al. Comparative metatranscriptomic analysis of anaerobic digesters treating anionic surfactant contaminated wastewater. Science of the Total Environment, v. 649, p. 482-494, 2019. Disponível em: <https://doi.org/10.1016/j.scitotenv.2018.08.328>.

DENG, Z. et al. Design of anaerobic fluidized bed bioreactor - Dyeing effluents. Chemical Engineering Science, v. 139, p. 273-284, 2016.

DI CELLO, F. et al. Molecular characterization of an n-alkane-degrading bacterial community and identification of a new species, Acinetobacter venetianus. Research in Microbiology, v. 148, n. 3, p. 237-249, 1997.

DIAO, P. et al. Phenolic endocrine-disrupting compounds in the Pearl River Estuary: Occurrence, bioaccumulation and risk assessment. Science of the Total Environment, v. 584-585, p. 1100-1107, 2017. Disponível em: <http://dx.doi.org/10.1016/j.scitotenv.2017.01.169>.

DIRECTIVA 2000/60/CE, . Diretiva 2000/60/CE do Parlamento Europeu e do Conselho, de 23 de Outubro de 2000, que estabelece um quadro de acção comunitária no domínio da política da água. Jornal Oficial das Comunidades Europeias, n. 327, 2000.

DOORN, M. R. J. et al. Wastewater Treatment and Discharge Contents. In: Guidelines for National Greenhouse Gas Inventories. [s.l: s.n.]

DUARTE, I. C. S. et al. Development of a Method by HPLC to Determine LAS and its Application in Anaerobic Reactors. J. Braz. Chem. Societe, v. 17, n. 7, p. 1360-1367, 2006.

DUARTE, I. C. S. et al. Degradation of detergent (linear alkylbenzene sulfonate) in an anaerobic stirred sequencing-batch reactor containing granular biomass. International Biodeterioration and Biodegradation, v. 64, n. 2, p. 129-134, 2010. Disponível em: <http://dx.doi.org/10.1016/j.ibiod.2009.12.003>.

EDGAR, R. C. Updating the $97 \%$ identity threshold for $16 \mathrm{~S}$ ribosomal RNA OTUs. Bioinformatics, v. 34, n. 14, p. 2371-2375, 2018.

EL-HEFNAWY, T.; HERNANDEZ, C.; STABILE, L. P. The endocrine disrupting alkylphenols and 4,4'-DDT interfere with estrogen conversion and clearance by mouse liver cytosol. Reproductive Biology, maio 2017. Disponível em: <http://linkinghub.elsevier.com/retrieve/pii/S1642431X17300025>. Acesso em: 26 jul. 2017.

EPA. Aquatic life ambient water quality criteria nonylphenol. [s.l: s.n.]. Disponível em: <www.epa.gov/waterscience/criteria/aqlife.html>.

EPA. Certain Nonylphenols and Nonylphenol Ethoxylates; Significant New Use Rule. v. 79, n. 190, p. 59186-59195, 2014a.

EPA. Project Quality Assurance and Quality Control. n. May, p. 114-143, 2014b.

EPA. Method 8000D - Determinative Chromatographic Separations. n. July, p. 1-57, 2014c. Disponível em: <https://www.epa.gov/sites/production/files/201512/documents/8000d.pdf>. 
ESTEBAN, S. et al. The endocrine disruptor nonylphenol induces sublethal toxicity in vascular plant development at environmental concentrations: A risk for riparian plants and irrigated crops? Environmental Pollution, v. 216, p. 480-486, 2016.

EVANGELISTA-BARRETO, N. S. et al. CHARACTERIZATION OF Aeromonas SPECIES ISOLATED FROM AN ESTUARINE ENVIRONMENT Norma. v. 13, n. 23, p. 5764-5771, 2010.

EVANS, P. J. et al. Metabolites Formed during Anaerobic Transformation of Toluene and oXylene and Their Proposed Relationship to the Initial Steps of Toluene Mineralization. v. 58, n. 2, p. 496-501, 1992.

FELIS, E.; MIKSCH, K. Nonylphenols degradation in the UV, UV/H2O2, O3 and UV/O3 processes - Comparison of the methods and kinetic study. Water Science and Technology, v. 71, n. 3, p. 446-453, 2015.

FONDI, M. et al. Genomic and phenotypic characterization of the species Acinetobacter venetianus. Scientific Reports, v. 6, 2016. Disponível em: <http://dx.doi.org/10.1038/srep21985>.

FORESTI, E. Fundamentos do processo de digestão anaeróbia. In: Taller y Seminario Latonoamericano de Tratamiento Anaerobio de Aguas Residuales, Montevidéu. Anais... Montevidéu: 1994.

FORTE, M. et al. Nonylphenol effects on human prostate non tumorigenic cells. Toxicology, v. 357-358, p. 21-32, 2016. Disponível em: <http://dx.doi.org/10.1016/j.tox.2016.05.024>.

FREITAS, W. K. De; MAGAlHÃES, L. M. S. Métodos e Parâmetros para Estudo da Vegetação com Ênfase no Estrato Arbóreo Methods and Parameters for Plant Survey with Emphasis on Arboreal Stratum. v. 19, n. 4, p. 520-539, 2012.

FRIES, E.; PÜTTMANN, W. Occurrence of 4-Nonylphenol in rain and snow. Atmospheric Environment, v. 38, n. 13, p. 2013-2016, 2004.

FUCHS, G.; BOLL, M.; HEIDER, J. Microbial degradation of aromatic compounds- From one strategy to fourNature Reviews Microbiology, 2011. .

FUESS, L. T. Biodigestão anaeróbia termofílica de vinhaça em sistemas combinados do tipo acidogênico-metanogênico para potencialização da recuperação de bioenergia em biorrefinarias de cana-de-açúcar de primeira geração. p. 344, 2017.

FUJITA, M. et al. Behaviour of nonylphenol ethoxylates in sewage treatment plants in Japan Biotransformation and ecotoxicity. Water Science and Technology, v. 42, n. 7-8, p. 23-30, 2000.

GAO, D. et al. Removal of surfactants nonylphenol ethoxylates from municipal sewagecomparison of an A/O process and biological aerated filters. Chemosphere, v. 97, p. 130-134, 2014. Disponível em: <http://dx.doi.org/10.1016/j.chemosphere.2013.10.083>.

GAO, D. et al. Seasonal variations in the concentration and removal of nonylphenol ethoxylates from the wastewater of a sewage treatment plant. Journal of Environmental Sciences (China), v. 54, p. 217-223, 2017. Disponível em: <http://dx.doi.org/10.1016/j.jes.2016.02.005>.

GAUTAM, G. J.; CHAUBE, R.; JOY, K. Toxicity and tissue accumulation of 4-nonylphenol 
in the catfish Heteropneustes fossilis with a note on prevalence of 4-NP in water samples Toxicity and tissue accumulation of 4-nonylphenol in the cat fi sh Heteropneustes fossilis with a note on prevalenc. Endocrine Disruptors ISSN:, v. 3, n. 1, p. 13, 2015.

GIGER, W.; BRUNNER, P. H.; SCHAFFNER, C. 4-nonylphenol in Sewage Sludge: Accumulation of Toxic Metabolites from Nonionic Surfactants Published by: American Association for the Advancement of Science Stable URL: http://www.jstor.org/stable/1694043. v. 225, n. 4662, p. 623-625, 1984.

GIRAFFA G. Enterococci from foods. FEMS Microbiology Reviews, v. 26, p. 163-171, 2002.

GORGA, M. et al. Occurrence and spatial distribution of EDCs and related compounds in waters and sediments of Iberian rivers. Science of the Total Environment, v. 503-504, p. 69-86, 2015. Disponível em: 〈http://dx.doi.org/10.1016/j.scitotenv.2014.06.037>.

HEIDER, J. et al. Anaerobic bacterial metabolism of hydrocarbons. FEMS Microbiology Reviews 22, v. 22, p. 459-473, 1999.

HEIDER, J. Adding handles to unhandy substrates: anaerobic hydrocarbon activation mechanisms. p. 188-194, 2007.

HENZE, M.; HARREMOES, P. Anaerobic Treatment of Wastewater in Fixed Film Reactors a Literature Review. Water Science \& Technology, v. 15, n. 8-9, p. 1-101, 1983.

HERLEMANN, D. P. R. et al. Genomic analysis of "Elusimicrobium minutum" the first cultivated representative of the phylum "Elusimicrobia" (formerly termite group 1). Applied and Environmental Microbiology, v. 75, n. 9, p. 2841-2849, 2009.

HOSHINO, S. et al. Arcyriaflavin E, a new cytotoxic indolocarbazole alkaloid isolated by combined-culture of mycolic acid-containing bacteria and Streptomyces cinnamoneus NBRC 13823. Journal of Antibiotics, v. 68, n. 5, p. 342-344, 2015. Disponível em: <http://dx.doi.org/10.1038/ja.2014.147>.

HOUF, K. et al. Arcobacter cibarius sp. nov., isolated from broiler carcasses. International Journal of Systematic and Evolutionary Microbiology, v. 55, n. 2, p. 713-717, 2005.

HYLEMON, P. B. et al. The Genus Spirillum: a Taxonomic Study. International Journal of Systematic Bacteriology, v. 23, n. 4, p. 340-380, 1973.

IINO, T. et al. Ignavibacterium album gen. nov., sp. nov., a moderately thermophilic anaerobic bacterium isolated from microbial mats at a terrestrial hot spring and proposal of Ignavibacteria classis nov., for a novel lineage at the periphery of green sulfur bacteria. International Journal of Systematic and Evolutionary Microbiology, v. 60, n. 6, p. 1376-1382, 2010.

IZA, J. Fluidized Bed Reactors for Anaerobic Wastewater Treatment. Water Science \& Technology, v. 24, n. 8, p. 109-132, 1991.

JIMENEZ, L. et al. Mineralization of linear alkylbenzene sulfonate by a four-member aerobic bacterial consortium. Applied and Environmental Microbiology, v. 57, n. 5, p. 1566$1569,1991$.

KALYANI, D. C. et al. Biodegradation of reactive textile dye Red BLI by an isolated bacterium Pseudomonas sp. SUK1. Bioresource Technology, v. 99, n. 11, p. 4635-4641, 2008.

KAPATRAL, V. et al. Genome sequence and analysis of the oral bacterium Fusobacterium nucleatum strain ATCC 25586. Journal of Bacteriology, v. 184, n. 7, p. 2005-2018, 2002. 
KARADAG, D. et al. A review on anaerobic biofilm reactors for the treatment of dairy industry wastewater. Process Biochemistry, v. 50, n. 2, p. 262-271, 2015.

KE, W. R. et al. Characterization of aerosol emissions from single bubble bursting. Journal of Aerosol Science, v. 109, n. March, p. 1-12, 2017. Disponível em: <http://dx.doi.org/10.1016/j.jaerosci.2017.03.006>.

KIROV, S. M. The public health significance of Aeromonas spp. in foods. International Journal of Food Microbiology, v. 20, n. 4, p. 179-198, 1993.

KRIEG, N. R. et al. Bergey's Manual of Systematic Bacteriology Vol. 4. [s.l: s.n.]

KRZMARZICK, M. J. et al. Diversity and Niche of Archaea in Bioremediation. Archaea, v. 2018, p. 1-17, 2018. Disponível em: <https://www.hindawi.com/journals/archaea/2018/3194108/>.

LAKOWICZ, J. R. Principles of Fluorescence Spectroscopy. $3^{\circ}$ edition ed. [s.l: s.n.]

LANÇAS, F. M. Efeitos de temperatura em Cromatografia Líquida de Alta Eficiência ( HPLC ) Temperature Effects in High Performance Liquid Chromatography ( HPLC ). Scientia Chromatographica, v. 4, n. 1, p. 13-19, 2012.

LANGFORD, K. H.; LESTER, J. N. Fate and behaviour of endocrine disrupters in wastewater treatment processes. In: BIRKETT, J. W.; LESTER, J. N. (Ed.). Endocrine disrupters in wastewater and sludge treatment processes. [s.l: s.n.]

LEE, C. C. et al. The potential role of water quality parameters on occurrence of nonylphenol and bisphenol $\mathrm{A}$ and identification of their discharge sources in the river ecosystems. Chemosphere, v. 91, n. 7, p. 904-911, 2013. Disponível em: <http://dx.doi.org/10.1016/j.chemosphere.2013.02.006>.

LEE, C. S. et al. Lysinibacillus xylanilyticus sp. nov., a xylan-degrading bacterium isolated from forest humus. International Journal of Systematic and Evolutionary Microbiology, v. 60, n. 2, p. 281-286, 2010.

LEVERENZ, H.; DARBY, J.; TCHOBANOGLOUS, G. Evaluation of Disinfection Units for Onsite Wastewater Treatment Systems. 2006.

LIESACK, W. et al. Holophaga foetida gen. nov., sp. nov., a new, homoacetogenic bacterium degrading methoxylated aromatic compounds. n. December 1992, p. 85-90, 1994.

LIJUN, X. et al. Linear alkyl benzene sulphonate (LAS) degradation by immobilized Pseudomonas aeruginosa under low intensity ultrasound. Colloids and Surfaces B: Biointerfaces, v. 40, n. 1, p. 25-29, 2005.

LIU, D. et al. Occurrence, distribution, and risk assessment of alkylphenols, bisphenol A, and tetrabromobisphenol A in surface water, suspended particulate matter, and sediment in Taihu Lake and its tributaries. Marine Pollution Bulletin, v. 112, n. 1-2, p. 142-150, 2016. Disponível em: <http://dx.doi.org/10.1016/j.marpolbul.2016.08.026>.

LIU, D. et al. Distribution and bioaccumulation of endocrine disrupting chemicals in water, sediment and fishes in a shallow Chinese freshwater lake: Implications for ecological and human health risks. Ecotoxicology and Environmental Safety, v. 140, n. February, p. 222-229, 2017. Disponível em: 〈http://dx.doi.org/10.1016/j.ecoenv.2017.02.045>.

LIU, J. F. et al. High performance liquid chromatography determination of 4-nonylphenol,4tert-octylphenol, and their short ethoxyl chain polyethoxylates in water samples using 
a microporous membrane liquid-liquid extraction sample pretreatment technique. Journal of Separation Science, v. 26, n. 9-10, p. 823-828, 2003.

LIU, Z. et al. Complete genome of Ignavibacterium album, a metabolically versatile, flagellated, facultative anaerobe from the phylum Chlorobi. Frontiers in Microbiology, v. 3, n. MAY, p. 1-15, 2012.

LOYO-ROSALES, J. E. et al. Migration of Nonylphenol from Plastic Containers to Water and a Milk Surrogate. Journal of Agricultural and Food Chemistry, v. 52, n. 7, p. 20162020, 2004.

LU, Z.; REIF, R.; GAN, J. Isomer-specific biodegradation of nonylphenol in an activated sludge bioreactor and structure-biodegradability relationship. Water Research, v. 68, p. 282-290, 2015.

LUDWIG, J. A.; REYNOLDS, J. F. Statistical ecology: a primer on methods and computing. New York: John Wiley \& Sons, Inc, 1988.

MACEDO, T. Z. et al. The comparative advantages of ethanol and sucrose as co-substrates in the degradation of an anionic surfactant: microbial community selection. Bioprocess and biosystems engineering, v. 38, n. 10, p. 1835-1844, 2015.

MACEDO, T. Z. Avaliação da influência da fonte suplementar de carbono na remoção de alquilbenzeno linear sulfonado de água de lavanderia e comunidade microbiana relacionada em reator anaeróbio de leito fluidificado. 2015. USP, 2015.

MANDELBAUM, R. T.; ALLAN, D. L.; WACKETT, L. Isolation and characterization of a Pseudomonas sp. that mineralizes the s-triazine herbicide atrazine. Applied and Environmental Microbiology, v. 61, n. 4, p. 1451-7, 1995.

MANZANO, M. A. et al. The effect of temperature on the biodegradation of a nonylphenol polyethoxylate in river water. Water Research, v. 33, n. 11, p. 2593-2600, 1998.

METCALF; EDDY. Wastewater engineering : treatment and reuse. [s.l: s.n.]

MOTTERAN, F. Caracterização da comunidade microbiana de reator anaeróbio de leito fluidificado envolvida na degradação de surfactante não iônico álcool etoxilado de cadeia não ramificada ( GENAPOL ). p. 187, 2013.

MOTTERAN, F. et al. Degradation of high concentrations of nonionic surfactant (linear alcohol ethoxylate) in an anaerobic fluidized bed reactor. Science of the Total Environment, v. 481, n. 1, p. 121-128, 2014a. Disponível em: <http://dx.doi.org/10.1016/j.scitotenv.2014.02.024>.

MOTTERAN, F. et al. Methanogenic potential of an anaerobic sludge in the presence ofanionic and nonionic surfactants. International Biodeterioration and Biodegradation, v. 96, p. 198-204, 2014b.

MOTTERAN, F. et al. Metabolic routes involved in the removal of linear alkylbenzene sulfonate (LAS) employing linear alcohol ethoxylated and ethanol as co-substrates in enlarged scale fluidized bed reactor. Science of the Total Environment, v. 640-641, p. 1411-1423, 2018. Disponível em: 〈https://doi.org/10.1016/j.scitotenv.2018.05.375>.

MURDOCH, F. K.; SANIN, F. D. Biotransformation of Nonylphenol Diethoxylate in anaerobic digesters: Accumulation of metabolites and their effects on digester performance. International Biodeterioration and Biodegradation, v. 110, p. 61-68, 2016. Disponível em: <http://dx.doi.org/10.1016/j.ibiod.2016.02.017>.

NARIHIRO, T. et al. The nexus of syntrophy-associated microbiota in anaerobic digestion 
revealed by long-term enrichment and community survey. Environmental Microbiology, v. 17, n. 5, p. 1707-1720, 2015.

NASU, M. et al. Study on endocrine disrupting chemicals in wastewater treatment plants. v. 43, n. 2, p. 101-108, 2001.

NEY, R. E. Where did that chemical go: a practical guide to chemical fate and transport in the environment. New York: Van Nostrand Reinhold, 1990.

NITSCHKE, M.; PASTORE, G. M. Biossurfactantes: Propriedades e Aplicações. Quimica Nova, v. 25, n. 5, p. 772-776, 2002.

OKADA, D. Y. Degradação de surfactante aniônico em reator UASB com água residuária de lavanderia. Escola de Engenharia de São Carlos, v. Doutorado, p. 226, 2012. Disponível em: <http://www.teses.usp.br/teses/disponiveis/18/18138/tde-30082012111908/pt-br.php>.

OKADA, D. Y. et al. Evaluation of the microbial community of upflow anaerobic sludge blanket reactors used for the removal and degradation of linear alkylbenzene sulfonate by pyrosequencing. International Biodeterioration and Biodegradation, v. 96, p. 6370, 2014. Disponível em: 〈http://dx.doi.org/10.1016/j.ibiod.2014.09.017〉.

OLIVEIRA, L. L. de et al. Influence of support material on the immobilization of biomass for the degradation of linear alkylbenzene sulfonate in anaerobic reactors. Journal of Environmental Management, v. 90, n. 2, p. 1261-1268, 2009.

OLIVEIRA, L. L. de et al. Anaerobic degradation of linear alkylbenzene sulfonate (LAS) in fluidized bed reactor by microbial consortia in different support materials. Bioresource Technology, v. 101, n. 14, p. 5112-5122, 2010. Disponível em: <http://dx.doi.org/10.1016/j.biortech.2010.01.141>.

PATELL, G.; SPROTT, G. Methanosaeta concilii. International Journal of Systematic Bacteriology, v. 40, n. 1, p. 79-82, 1990.

PEIXOTO, G. et al. Hydrogen and methane production, energy recovery, and organic matter removal from effluents in a two-stage fermentative process. Applied biochemistry and biotechnology, v. 3, p. 651-671, 2012.

PENG, F. J. et al. Occurrence and ecological risk assessment of emerging organic chemicals in urban rivers: Guangzhou as a case study in China. Science of the Total Environment, v. 589, p. 46-55, 2017. Disponível em: <http://dx.doi.org/10.1016/j.scitotenv.2017.02.200>.

PERKINS, S. D.; SCALFONE, N. B.; ANGENENT, L. T. Comparative 16S rRNA gene surveys of granular sludge from three upflow anaerobic bioreactors treating purified terephthalic acid (PTA) wastewater. n. June, p. 1406-1413, 2011.

PERNA, V. et al. Hydrogen production in an upflow anaerobic packed bed reactor used to treat cheese whey. International Journal of Hydrogen Energy, v. 38, n. 1, p. 54-62, 2013.

PETROVIC, M. et al. Endocrine disruptors in sewage treatment plants, receiving river waters, and sediments: integration of chemical analysis and biological effects on feral carp. Environmental toxicology and chemistry / SETAC, v. 21, n. 10, p. 2146-2156, 2002a.

PETROVIC, M. et al. Occurrence and distribution of nonionic surfactants, their degradation products, and linear alkylbenzene sulfonates in coastal waters and sediments in Spain. Environmental Toxicology and Chemistry, v. 21, n. 1, p. 37-46, 2002 b. 
PIELOU, E. C. Species-Diversity and Pattern-Diversity in the Study of Ecological Succession. J. Theoret. Biol., v. 10, p. 370-383, 1966.

PINTADO-HERRERA, M. G. et al. Occurrence and spatial distribution of legacy and emerging organic pollutants in marine sediments from the Atlantic coast (Andalusia, SW Spain). Science of the Total Environment, v. 605-606, p. 980-994, 2017. Disponível em: <http://dx.doi.org/10.1016/j.scitotenv.2017.06.055>.

PLOTNIKOVA, E. G. et al. Bacterial degraders of poly cyclic aromatic hydrocarbons isolated from salt-contaminated soils and bottom sediments in salt mining areas. Microbiology, v. 70, n. 1, p. 51-58, 2001.

PRIAC, A. et al. Alkylphenol and alkylphenol polyethoxylates in water and wastewater: A review of options for their elimination. Arabian Journal of Chemistry, v. 10, p. S3749S3773, 2014.

RAMSEY, M.; HARTKE, A.; HUYCKE, M. The Physiology and Metabolism of Enterococci. Gilmore MS ed. Boston: Massachusetts Eye and Ear Infirmary, 2014.

REBELLO, S. et al. Surfactants: toxicity, remediation and green surfactants. Environmental Chemistry Letters, v. 12, n. 2, p. 275-287, 2014. Disponível em: $<$ http://link.springer.com/10.1007/s10311-014-0466-2>.

RIBANI, M. et al. Validação em métodos cromatográficos e eletroforéticos. Quimica Nova, v. 27, n. 5, p. 771-780, 2004.

RIPLEY, L. E.; BOYLE, W. C.; CONVERSE, J. C. Improved alkalimetric monitoring for anaerobic digestion of high-strength wast. v. 58, n. 5, p. 406-411, 1986.

RIVERO, C. L. G. et al. Evaluation of genotoxicity and effects on reproduction of nonylphenol in Oreochromis niloticus (Pisces: cichlidae). Ecotoxicology, v. 17, n. 8, p. 732-737, 2008.

RODRIGUEZ-MORALES, A. J.; CASTAÃEDA-HERNÃNDEZ, D. M. Bacteria: Aeromonas. Encyclopedia of Food Safety, v. 1, p. 342-343, 2014.

RUIZ, Y. et al. Biodegradation of polyethoxylated nonylphenols. ISRN microbiology, v. 2013, 2013. Disponível em: <http://search.ebscohost.com/login.aspx?direct=true\&AuthType=cookie,ip,shib\&db $=$ awn \&AN=23936727\&site=ehost-live $>$.

SALAGUER, J.-L. SURFACTANTS, Types and Uses. Laboratory of Formulation, Interfaces, Rheology and Processes, v. 2, p. 1-49, 2002.

SALGUEIRO-GONZÁLEZ, N. et al. Occurrence, distribution and bioaccumulation of endocrine disrupting compounds in water, sediment and biota samples from a European river basin. Science of the Total Environment, v. 529, p. 121-130, 2015. Disponível em: <http://dx.doi.org/10.1016/j.scitotenv.2015.05.048>.

SANZ, J. L. et al. Anaerobic biodegradation of linear alkylbenzene sulfonate (LAS) in upflow anaerobic sludge blanket (UASB) reactors. Biodegradation, v. 14, n. 1, p. 57-64, 2003.

SAYED, A. E. D. H.; HAMED, H. S. Induction of apoptosis and DNA damage by 4nonylphenol in African catfish (Clarias gariepinus) and the antioxidant role of Cydonia oblonga. Ecotoxicology and Environmental Safety, v. 139, n. September 2016, p. $97-$ 101, 2017. Disponível em: 〈http://dx.doi.org/10.1016/j.ecoenv.2017.01.024>.

SCHINK, B. Fermentation of 2,3-butanediol by Pelobacter carbinolicus sp. nov., and evidence for propionate formation from C2 compounds. p. 33-41, 1984. 
SCHINK, B.; PFENNIG, N. Fermentation of trihydroxybenzenes by Pelobacter acidigallici gen. nov. sp. nov., a new strictly anaerobic, non-sporeforming bacterium. Archives of Microbiology, v. 133, n. 3, p. 195-201, 1982.

SCHMITT, R. et al. Biodegradation of aromatic hydrocarbons under anoxic conditions in a shallow sand and gravel aquifer of the Lower Rhine Valley, Germany. Org. Geochem., v. 25, n. 1, p. 41-50, 1996.

SEYFRIED, B. et al. Initial Reactions in the Anaerobic Oxidation of Toluene and $\mathrm{m}$-Xylene by Denitrifying Bacteria. v. 60, n. 11, p. 4047-4052, 1994.

SHANG, D. Y.; MACDONALD, R. W.; IKONOMOU, M. G. Persistence of nonylphenol ethoxylate surfactants and their primary degradation products in sediments from near a municipal outfall in the Strait of Georgia, British Columbia, Canada. Environmental Science and Technology, v. 33, n. 9, p. 1366-1372, 1999.

SHANNON, C. E.; WEAVER, W. A Mathematical Theory of Communication. [s.l.] University Illinois Press, Urbana., 1948. v. 27

SHAO, B.; HU, J.; YANG, M. Nonylphenol ethoxylates and their biodegradation intermediates in water and sludge of a sewage treatment plant. Bulletin of Environmental Contamination and Toxicology, v. 70, n. 3, p. 527-532, 2003.

SHARMA, M.; CHADHA, P. Widely used non-ionic surfactant 4-nonylphenol: showing genotoxic effects in various tissues of Channa punctatus. Environmental Science and Pollution Research, v. 24, n. 12, p. 11331-11339, 2017.

SHIEH, W. K.; KEENAN, J. D. Fluidized bed biofilm reactor for wastewater treatment. Biotechnology, v. 33, p. 131-169, 1986. Disponível em: <http://www.springerlink.com/index/10.1007/BFb0002455>.

SHIEH, W. K.; MULCAHY, L. T.; LAMOTTA, E. J. Mathematical model for the fluidized bed biofilm reactor. Enzyme and Microbial Technology, v. 4, n. 4, p. 269-275, 1982.

SHIGEMATSU, T. et al. Delftia tsuruhatensis sp. nov., a terephthalate-assimilating bacterium isolated from activated sludge. International Journal of Systematic and Evolutionary Microbiology, v. 53, n. 5, p. 1479-1483, 2003.

SHIRDEL, I.; KALBASSI, M. R. Effects of nonylphenol on key hormonal balances and histopathology of the endangered Caspian brown trout (Salmo trutta caspius). Comparative Biochemistry and Physiology Part - C: Toxicology and Pharmacology, v. 183-184, p. 28-35, 2016. Disponível em: <http://dx.doi.org/10.1016/j.cbpc.2016.01.003>.

SIGMA-ALDRICH. Safety Data Sheet. n. 453, p. 1-8, 2015.

SIMPSON, E. H. Measurement of diversity. Nature, v. 163, p. 688., 1949.

SMITH, K. S.; INGRAM-SMITH, C. Methanosaeta, the forgotten methanogen? Trends in Microbiology, v. 15, n. 4, p. 150-155, 2007.

SOARES, A. et al. Nonylphenol in the environment: A critical review on occurrence, fate, toxicity and treatment in wastewaters. Environment International, v. 34, n. 7, p. 10331049, 2008.

SOTO, A. M. et al. P-Nonyl-phenol: An estrogenic xenobiotic released from " "modified" polystyrene. Environmental Health Perspectives, v. 92, n. Cd, p. 167-173, 1991. 
SPEECE, R. E. Anaerobic biotechnology for industrial wastewater treatment. Environmental Science and Technology, v. 17, n. 9, p. 416A-427A, 1983.

STAMS, A. Metabolic Interactions Between Anaerobic-Bacteria in Methanogenic Environments. Antonie Van Leeuwenhoek International Journal of General and Molecular Microbiology, v. 66, n. 1-3, p. 271-294, 1994.

STARR, M. P. et al. The Prokaryotes: A Handbook on Habitats, Isolation, and Identification of Bacteria. [s.l: s.n.]

TANG, Z. yong et al. Lycium barbarum polysaccharide alleviates nonylphenol exposure induced testicular injury in juvenile zebrafish. International Journal of Biological Macromolecules, v. 104, p. 618-623, 2017. Disponível em: <http://dx.doi.org/10.1016/j.ijbiomac.2017.06.035>.

THIELE, B. et al. Contribution to the structural elucidation of 110 isomers of technical pNonylphenol. Environmental Science and Technology, v. 38, n. 12, p. 3405-3411, 2004.

TRUFELLI, $H$. et al. An overview of matrix effects in liquid chromatography-mass spectrometry. Mass Spectrometry Reviews, v. 30, n. 3, p. 491-509, maio 2011.

TUKEY, J. W. Comparing Individual Means in the Analysis of Variance. Biometric, v. 5, n. 2, p. $99-114,1949$.

UGUZ, C. et al. Effects of nonylphenol on motility and subcellular elements of epididymal rat sperm. Reproductive Toxicology, v. 28, n. 4, p. 542-549, 2009.

VANEECHOUTTE, M. et al. Description of Acinetobacter venetianus ex Di Cello et al. 1997 sp. nov. International Journal of Systematic and Evolutionary Microbiology, v. 59, n. 6, p. 1376-1381, 2009.

VOS, P. De et al. Bergey's manual of systematic bacteriology - Vol 3: The Firmicutes. [s.l: s.n.]

WANG, B. et al. Phenolic endocrine disrupting chemicals in an urban receiving river (Panlong river) of Yunnan-Guizhou plateau: Occurrence, bioaccumulation and sources. Ecotoxicology and Environmental Safety, v. 128, p. 133-142, 2016. Disponível em: <http://dx.doi.org/10.1016/j.ecoenv.2016.02.018>.

WATVE, M. G. et al. How many antibiotics are produced by the genus Streptomyces? Archives of Microbiology, v. 176, n. 5, p. 386-390, 2001.

WHITE, R. et al. Environmentally persistent alkylphenolic compounds are estrogenic. Endocrinology, v. 135, n. 1, p. 175-182, 1994.

WOLF, M. et al. Phylogeny of Firmicutes with special reference to Mycoplasma (Mollicutes) as inferred from phosphoglycerate kinase amino acid sequence data. International Journal of Systematic and Evolutionary Microbiology, v. 54, n. 3, p. 871-875, 2004.

WU, J.-J. et al. Differential effects of nonylphenol on testosterone secretion in rat Leydig cells. Toxicology, v. 268, n. 1-2, p. 1-7, 2010.

YING, G.-G. Distribution, Behavior, Fate, and Effects of Surfactants and Their Degradation Products in the Environment. Handbook of Detergentes, n. October, p. 77-109, 2004.

YU, J. et al. Adverse effects of chronic exposure to nonylphenol on non-alcoholic fatty liver disease in male rats. PloS one, v. 12, n. 7, p. e0180218, 2017.

ZAIAT, M. Desenvolvimento e análise de biorreatores anaeróbios contendo células imobilizadas para tratamento de águas residuárias. Universidade de São Paulo, 2003. 
ZHANG, J. et al. Biotransformation of nonylphenol ethoxylates during sewage treatment under anaerobic and aerobic conditions. Journal of Environmental Sciences, v. 20, n. 2, p. 135-141, 2008.

ZHANG, Q. et al. Comparative toxicity of nonylphenol, nonylphenol-4-ethoxylate and nonylphenol-10-ethoxylate to wheat seedlings (Triticum aestivum L.). Ecotoxicology and Environmental Safety, v. 131, p. 7-13, 2016. Disponível em: <http://dx.doi.org/10.1016/j.ecoenv.2016.04.035>.

ZWIETERING, M. H. et al. Modeling of the bacterial growth curve. Applied and environmental microbiology., v. 56, n. 6, p. 1875-1881, 1990. 